MAURO FERREIRA

\title{
Planejamento Urbano nos tempos do SERFHAU: o processo de construção e implementação do Plano Diretor de Desenvolvimento Integrado de Franca
}

Tese apresentada à Escola de Engenharia de São Carlos / USP para obtenção do título de Doutor em Arquitetura e Urbanismo.

Área de Concentração: Teoria e História da Arquitetura e do Urbanismo

Orientadora: Profa. Dra. Sarah Feldman 
Ficha catalográfica preparada pela Seção de Tratamento da Informação do Serviço de Biblioteca - EESC/USP

\begin{tabular}{|c|c|}
\hline \multirow[t]{4}{*}{ F383p } & $\begin{array}{l}\text { Ferreira, Mauro } \\
\quad \text { Planejamento urbano nos tempos do SERFHAU : o } \\
\text { processo de construção e implementação do plano diretor } \\
\text { de desenvolvimento integrado de Franca / Mauro Ferreira; } \\
\text { orientadora Sarah Feldman. -- São Carlos, } 2007 \text {. }\end{array}$ \\
\hline & $218 \mathrm{p}$ \\
\hline & $\begin{array}{l}\text { Tese (Doutorado-Programa de Pós-Graduação em } \\
\text { Arquitetura e Urbanismo. Área de Concentração: Teoria e } \\
\text { História da Arquitetura e do Urbanismo) - Escola de } \\
\text { Engenharia de São Carlos da Universidade de São Paulo, } \\
\text { 2007. }\end{array}$ \\
\hline & $\begin{array}{l}\text { 1. Plano diretor (Franca). 2. Planejamento urbano. } 3 . \\
\text { Grupo de planejamento integrado. I. Título. }\end{array}$ \\
\hline
\end{tabular}




\section{Agradecimentos}

À orientadora e amiga Sarah Feldman, pelo estímulo permanente, pela crítica certeira, pelo rigor implacável e pela dedicação à universidade pública.

Aos professores Renato Luiz Sobral Anelli e Maria Adélia Aparecida de Souza pelas sugestões oferecidas na Banca do Exame de Qualificação.

Ao professor Ioshiaqui Shimbo, pelas idéias iniciais da pesquisa, pela hospedagem em São Carlos, disposição e animação permanente ao trabalho e, acima de tudo, pela amizade fraterna.

Ao professor Nabil Georges Bonduki, pela acolhida na superação dos entraves burocráticos de acesso ao programa de pósgraduação da EESC-USP.

Aos colegas estudantes da EESC-USP e do grupo de pesquisa da profa. Sarah, pela convivência e debates enriquecedores.

Às bibliotecárias da Unesp-Franca, Lucilene, Lurdinha e Laura, pela gentileza e atenção durante o processo de pesquisa.

Aos funcionários Daniel e Margarida Pansani, do Museu Histórico de Franca, Luizinho Goulart, da Câmara Municipal de Franca, Beto Chagas, Cecília Fuentes, Marta Faria e Luis Garcia, da Prefeitura de Franca, pela inestimável ajuda com o material de pesquisa.

Ao meus alunos Flávio Tilápia e Sirleno, por transformar aerofotos em mapas. 
Aos ex-integrantes do GPI, por sua generosidade em lutar por um Brasil mais justo e pela disponibilidade em resgatar a história e a memória de tempos de escuridão.

Aos ex-prefeitos e ex-secretários da Prefeitura de Franca, pela disponibilidade em partilhar suas vivências, experiências e memórias.

Ao Osório Calil Jr., Wilson Luis Italiano, Linda Teresinha Saturi, Antônio Faria, Emiliana Maquiaveli Cardoso e Osmar Parra, pela amizade e trabalho conjunto.

Ao Gilmar Dominici e Maurício Sandoval Ribeiro, exprefeitos de Franca que me honraram com a possibilidade de servir minha cidade e participar diretamente do seu processo de planejamento urbano.

À Fundação de Ensino Superior de Passos - FESP, Universidade do Estado de Minas Gerais - UEMG e Fundação de Amparo à Pesquisa de Minas Gerais - FAPEMIG, pelo indispensável apoio material.

Aos meus pais, que sempre quiseram ver os filhos na escola.

À Atalie, Natalie e Pablo, pela solidariedade garantida. 
"Já que tudo é histórico, a história será o que nós escolhermos"

Paul Veyne

"Contar é muito dificultoso. Não pelos anos que se já passaram, mas pela astúcia que têm certas coisas passadas"

Jỗo Guimarães Rosa

"Nada de parar. Devemos continuar a escavar! Cada vulto, gesto, palavra ou canção que parecia perdido para sempre, uma vez reencontrado, nos ajuda a sobreviver."

Norberto Bobbio 



\section{RESUMO}

Este trabalho reconstrói o processo de elaboração e implementação do Plano Diretor de Franca desde os anos 1960, a partir das propostas e práticas desenvolvidas na Prefeitura Municipal, destacando-se trabalhos influenciados pelo IBAM em 1963 para uma reforma administrativa e de empresa privada de consultoria, o GPI - Grupo de Planejamento Integrado, a partir de 1967, para elaboração do Plano Diretor de Desenvolvimento Integrado - PDDI.

Desenvolvemos o trabalho a partir de dois eixos principais de análise: o primeiro se refere à elaboração do PDDI pela empresa GPI, e o segundo ao processo de elaboração e implantação do plano. As análises desenvolvidas levam em consideração as críticas presentes na literatura sobre o planejamento dos anos 60 e 70.

Em relação ao GPI, desvendamos seu processo de constituição como empresa de consultoria no campo do planejamento urbano, associando empresas da área de administração pública, planejamento físico-territorial e análises econômicas, e a composição de sua equipe que reuniu técnicos de alta qualificação, em boa parte vinculados à oposição ao regime militar. Mostramos que o GPI, ao reunir militantes da esquerda, permitiu uma estratégia de sobrevivência a perseguidos políticos.

Quanto ao processo de elaboração e implantação do PDDI, mostramos que se desenvolveu de 1967 a 1996. O plano utilizou a metodologia adotada pelo Serviço Federal de Habitação e Urbanismo - SERFHAU, que privilegiava um diagnóstico dos problemas urbanos e racionalidade na elaboração do Plano. Embora os efeitos sobre o espaço urbano destes planos tenham sido muito criticados por sua escassa eficácia, apontada por significativo número de trabalhos, a partir de entrevistas, de pesquisa em jornais locais, levantamento de legislação e de documentos elaborados pelo GPI, verificamos a realização de significativa parcela das intervenções físicas e obras contidos nos estudos e nas propostas do Plano Diretor, assim como de indicações referentes à reforma administrativa da Prefeitura. $\mathrm{O}$ impacto da reestruturação e das ações implementadas não pode ser considerado desprezível, (como a criação do Distrito Industrial). Verificamos ainda que o diagnóstico, longe de ser irreal, levava em conta as condições urbanas locais. 
O Plano estabeleceu um conjunto de compromissos do governo municipal e de suas elites industriais para a expansão e o controle do espaço urbano; a idéia da "modernização tecnocrática" difundida por setores do regime militar e a metodologia do Plano Diretor do período do SERFHAU, de racionalidade da organização espacial do processo produtivo impuseram a organização do espaço industrial e da cidade.

Aquilo que se propunha no Plano Diretor, como infra-estrutura geral da cidade (uma concepção de cidade "racional" para a acumulação capitalista), em relação ao sistema viário, aos locais para instalação da indústria e comércio, era o que o capital industrial calçadista necessitava para sua acumulação e expansão, o que motivou sua defesa e aplicação pelos setores dominantes locais, garantindo continuidade administrativa e a consolidação de uma estrutura de planejamento na prefeitura.

Palavras-chave: 1. Plano diretor (Franca). 2. Planejamento urbano. 3. Grupo de Planejamento Integrado. 


\section{ABSTRACT}

This work reconstructs the elaboration and implementation process of the Master Plan of Franca since the years of 1960s, starting from the proposals and practices developed at the Municipal City Hall, standing out works influenced by IBAM in 1963 for an administrative reform and of a private advisory company, GPI - Integrated Planning Group, starting from 1967, to the elaboration of the Master Plan of Integrated Development - PDDI.

We developed the work starting from two main points of analysis: the first refers to the elaboration of the PDDI by the company GPI, and the second to the elaboration and introduction process of the plan. The developed analyses take into consideration the critics shown in the literature about the planning of the years 60 and 70.

In relation to the GPI, we unmasked its constitutional process as an advisory company in the field of the urban planning, associating companies in the area of public administration, physical- territorial planning and economical analyses, and the composition of its team that gathered technicians of high qualification, most of them linked to the opposition to the military regiment. We showed that GI, when gathering militants of the left, allowed a survival strategy to the political pursued.

As for the process of elaboration and implantation of the PDDI, we revealed that it was developed from 1967 to 1996. The plan used the methodology adopted by the Federal Service of Housing and Urbanization - SERFHAU, which privileged a diagnosis of the urban problems and rationality in the elaboration of the Plan. Although the effects on the urban space of these plans have been criticized a lot by its scarce effectiveness, shown by a significant number of papers, starting from interviews, of researches in local newspapers, a survey of legislations and documents elaborated by the GPI, we verified the accomplishment of significant fragments of the physical interventions and works contained in the studies and in the proposals of the Master Plan, as well as indications referring to the administrative reform of the City Hall. The impact of the restructuring and of the implemented actions cannot be considered despicable, (like the creation of the Industrial District). We still verified the diagnosis, far away from being unreal; it took into account the local urban conditions. 
The Plan established a set of commitments of the municipal government and of its industrial elites for the expansion and the control of the urban space; the idea of the "technocratic modernization ", spread for sections of the military regiment and the methodology of the Master Plan of the period of the SERFHAU, the space organization rationality of the productive process imposed the organization of the industrial space and of the city.

What was intended in the Master Plan, as a general infrastructure of the city (a conception of rational " city " for the capitalist accumulation) in relation to the road and traffic system, to the places for the installation of industry and trade, it was what the industrial shoe capital needed for its accumulation and expansion, what motivated its defense and application for the local dominant sections, guaranteeing administrative continuity and the consolidation of a planning structure in the city hall.

Key words: 1. Master Plan (Franca). 2. Urban planning. 3. Integrated Planning Group. 


\section{FIGURAS}

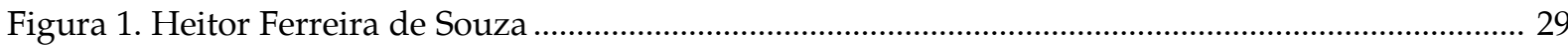

Figura 2. Diógenes de Arruda Câmara no exílio, nos anos 1970 ……………………………………... 30

Figura 3. Contrato social do GPI, publicado no D.O.E.S.P de 11 de dezembro de 1967 .......................... 33

Figura 4. Carlos Walter Aumond, que assumiu a direção técnica do GPI após a prisão de Arruda

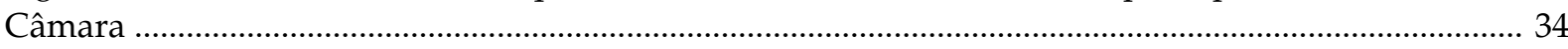

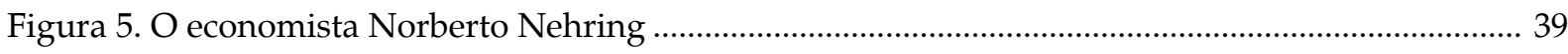

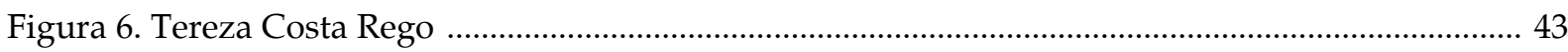

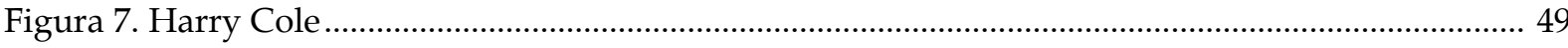

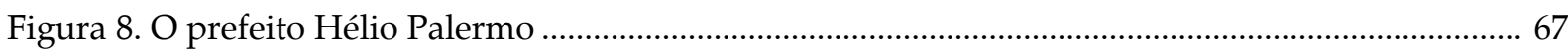

Figura 9. Hélio Palermo discursa em evento político ……………………............................................ 71

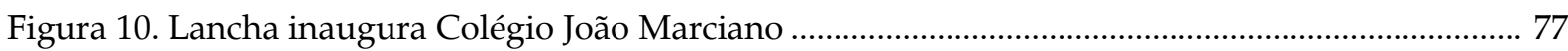

Figura 11. Convite para o Seminário de Avaliação do Plano Diretor ........................................................ 79

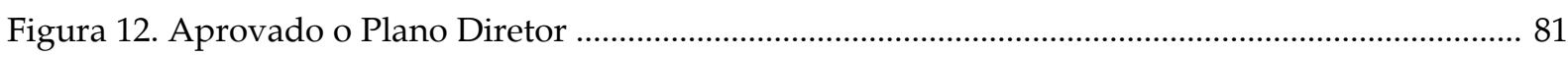

Figura 13. Saneamento do Córrego do Cubatão entre Av. Champagnat e a cachoeira ........................... 82

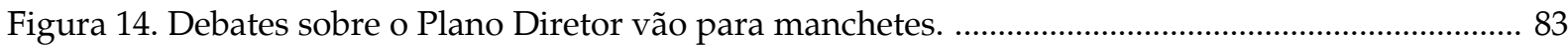

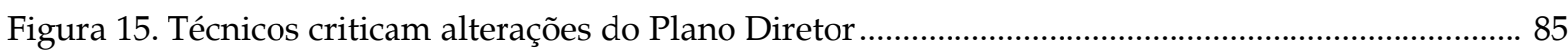

Figura 16. Jornal Diário da Franca de 13 de março de 1976 . ................................................................... 85

Figura 17. Editorial do Jornal Diário da Franca, de 1974, critica os vazios urbanos ................................. 86

Figura 18. Associação dos Engenheiros e Arquitetos cobra Distrito Industrial para a cidade ............... 87

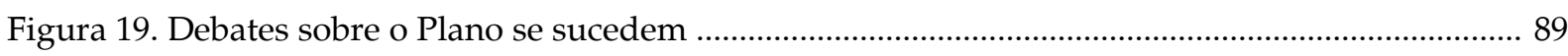

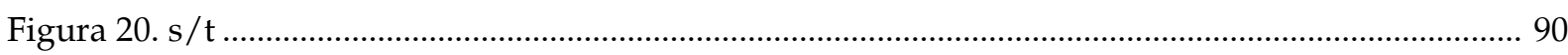

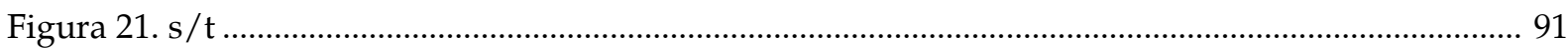

Figura 22. Técnicos são derrotados em disputa jurídica sobre alterações do Plano Diretor .................... 92

Figura 23. Obras de ampliação da avenida marginal ao córrego do Cubatão e do sistema viário na

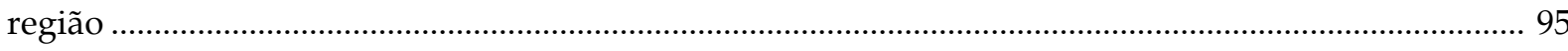

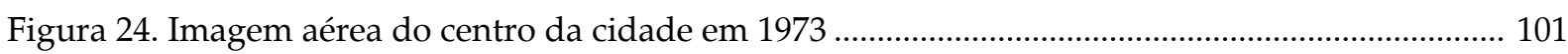

Figura 25. Franca por volta de 1973: escassa verticalização e novos bairros na periferia. ...................... 103

Figura 26. Novos bairros são rapidamente constituídos, no início dos anos 70. ..................................... 103

Figura 27. O prefeito Lancha Filho inspeciona as obras do Estádio Municipal em 1969 ...................... 112

Figura 28. O estádio municipal logo após sua inauguração, em 1969 ……………………………..... 113

Figura 29. Os pavilhões recém construídos da Francal em meados dos anos 1970. .............................. 117

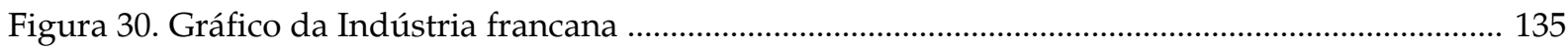




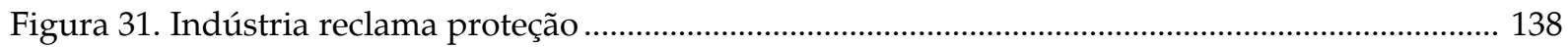

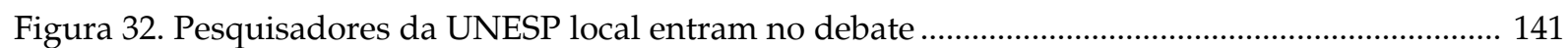

Figura 33. Reclamações contra a indústria curtumeira repercutem na imprensa .................................. 141

Figura 34. Folder de Divulgação do Distrito Industrial de Franca .......................................................... 143

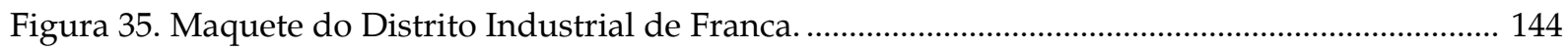

Figura 36. Vista atual do Distrito Industrial de Franca. ...................................................................... 145

Figura 37. Vista atual do Distrito Industrial de Franca. ...................................................................... 146

Figura 38. Vista atual da Rotatória da Av. Ismael Alonso com Av. Champagnat. ................................ 146

Figura 39. Vista atual da Rotatória da Avenida Ismael Alonso com Rua Saldanha Marinho. ............. 147

Figura 40. Vista atual da Rotatória da Avenida Ismael Alonso com Avenida Major Nicácio.............. 147

Figura 41. Obras de canalização da Avenida Ismael Alonso nos anos 60. ............................................ 147

Figura 42. Trecho canalizado da Avenida Ismael Alonso. .................................................................. 147

Figura 43. Vista atual da Rotatória da Avenida Major Nicácio com Presidente Vargas. ....................... 148

Figura 44. Lancha e membros de sua equipe visitam obras de canalização do córrego dos Bagres ... 148

Figura 45. Canalização do córrego dos Bagres na avenida Hélio Palermo, após destruição da

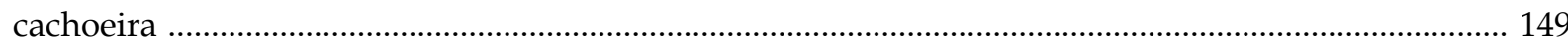

Figura 46. Vista atual da avenida Major Nicácio e rotatória com avenida Hélio Palermo. .................. 149

Figura 47. Vista atual do cruzamento da avenida Presidente Vargas com avenida D. Pedro I. .......... 150

Figura 48. Vista atual do cruzamento da av. Presidente Vargas com D.Pedro I. .................................. 150

Figura 49. Vista atual da avenida Orlando Dompieri.......................................................................... 151

Figura 50. Vista atual da avenida Orlando Dompieri com avenida Flávio Rocha. ................................ 151

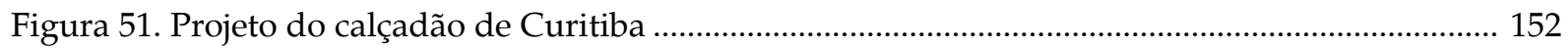

Figura 52. Calçadão da rua do Comércio em construção .......................................................................... 153

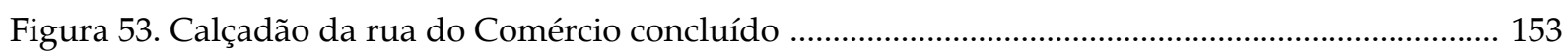

Figura 54. Vista atual do calçadão da Rua do Comércio. .................................................................... 153

Figura 55. Vista atual do calçadão da rua Mal. Deodoro, construída na segunda gestão de Hélio

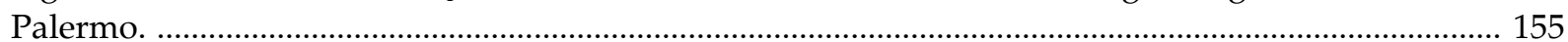

Figura 56. Vista atual da rua Mal. Deodoro, transformada em calçadão no primeiro governo de

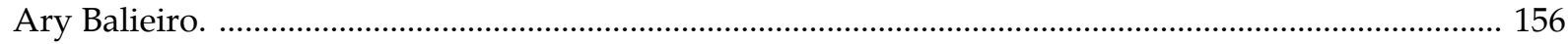

Figura 57. Vista atual da rua Gal. Telles, transformada em calçadão em 1988, no governo de

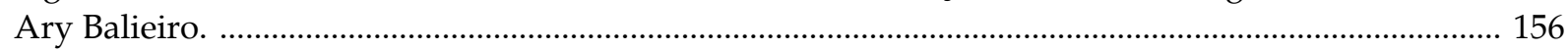

Figura 58. Vista atual da rua do Comércio e praça Barão da Franca, transformadas em calçadão ..... 156

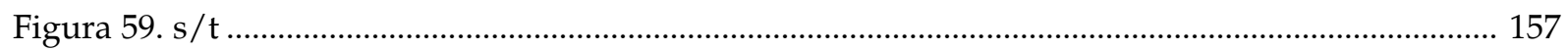

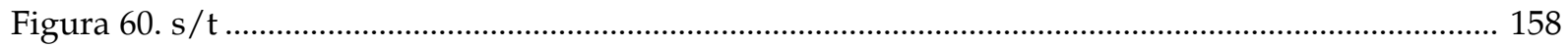

Figura 61. Vista atual do calçadão da rua do Comércio. ..................................................................... 159

Figura 62. Vista geral do vale do Córrego dos Bagres antes de sua urbanização, nos anos 60 ............ 160

Figura 63. Vista atual do córrego dos Bagres, após sua última reurbanização, no início dos anos 90 .... 161

Figura 64. Vista atual do que restou do parque do Vale dos Bagres. .................................................... 162

Figura 65. Vista atual do que restou do parque do Vale dos Bagres. .................................................... 162

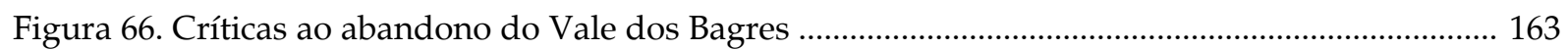

Figura 67. Vista atual da praça implantada na voçoroca do Parque São Jorge, projetada pelo autor em 1980, durante a gestão de Maurício Ribeiro. ....................................................................................... 165

Figura 68. Vista atual da área esportiva, implantada em 1984, na gestão de Sidnei Rocha.................. 165

Figura 69. Vista atual do restante da área da voçoroca do Parque São Jorge, não urbanizada ............. 166 
Figura 70. Vista da área esportiva da voçoroca do Parque São Jorge.

Figura 71. Vista atual de parte urbanizada da voçoroca das Maritacas, construída durante o governo de Ary Balieiro, em 1994.

Figura 72. Vista atual de parte já aterrada, porém não urbanizada da voçoroca das Maritacas........... 166

Figura 73. Vista atual de área esportiva implantada na voçoroca das Maritacas, construída no governo de Ary Balieiro, em 1994

Figura 74. Vista atual da área esportiva da voçoroca das Maritacas. ...................................................... 167

Figura 75. Vista atual do aterro sanitário industrial das Maritacas, após seu encerramento. 167

Figura 76. Vista atual da praça implantada na voçoroca da Vila Monteiro, construída durante o governo de Ary Balieiro, em 1995.

Figura 77. Vista atual da praça implantada na voçoroca da Vila Monteiro. 168

Figura 78. Vista atual da voçoroca da Boa Vista, com equipamentos esportivos deteriorados. ........... 168

Figura 79. Foto atual do Centro Social Urbano, construído dentro da voçoroca da Boa Vista. ........... 169

Figura 80. Vista atual de parte da voçoroca da Boa Vista, ainda não urbanizada. ................................ 169

Figura 81. Vista da avenida Major Nicácio, construída sobre a voçoroca do Pestalozzi........................ 170

Figura 82. Vista atual da voçoroca do Jardim Conceição Leite, ainda não urbanizada, mas pertencente à Prefeitura com finalidade de implantar área verde.

Figura 83. Vista atual da voçoroca da Vila Raycos, que está sendo aterrada com resíduos da construção civil.

Figura 84.Vista atual da voçoroca da Vila Raycos.

Figura 85. Vista atual de equipamento esportivo implantado na voçoroca da Ponte Preta, durante o governo de Gilmar Dominici (2003)

Figura 86. Vista atual da voçoroca da Ponte Preta, após urbanização.

Figura 87. Vista atual da voçoroca da vila Palmeiras, onde foi implantada a rodoviária da cidade, com ampla área verde em seu entorno, realizada em 1981, no governo de Maurício Sandoval Ribeiro.

Figura 88. Vista atual da voçoroca Manoel Valim, onde foi implantada escola municipal durante o governo de Lancha Filho, em 1972.

Figura 89. Vista atual da voçoroca da Scarabucci, onde há uma gleba pertencente à Prefeitura que abriga campo esportivo, embora não seja urbanizada.

Figura 90. Vista atual da praça construída em 1982 na voçoroca do Quirino, projeto do autor.

Figura 91. Vista atual da area esportiva implantada na voçoroca do Chiné, construída durante o governo de Ary Balieiro, em 1988.

Figura 92. Vista da atual área de lazer da voçoroca do Chiné.

Figura 93. Vista atual da voçoroca de Higienópolis, onde foi implantado equipamento desportivo, durante o governo de Ary Balieiro, em 1988.

Figura 94. Vista atual da voçoroca de Higienópolis, após implantação de praça, durante o segundo governo de Ary Balieiro, em 1994

Figura 95. Vista atual de equipamento desportivo na voçoroca de Higienópolis.

Figura 96. Vista atual da voçoroca Adalgisio Leite, que foi aterrada, embora ainda não urbanizada, pertencente à Prefeitura.

Figura 97. Vista atual da canalização do córrego do Cubatão, no encontro com o córrego dos Bagres. .176 Figura 98. Paço Municipal no início dos anos 70, logo após sua ocupação pela Prefeitura 178

Figura 99. A importância do planejamento durante o Regime Militar foi objeto de ironia pelo cartunista Ziraldo 


\section{QUADRO}

Quadro1: Resumo dos Principais Dirigentes Governamentais 63

\section{TABELAS}

Tabela 1. Produção anual de calçados em Franca

Tabela 2. Número de Documentos Concluídos Financiados pelo FIPLAN até setembro/1973 na Região Sudeste

Tabela 3. Número de Documentos em Elaboração Financiados pelo FIPLAN até setembro/1973 na Região Sudeste

Tabela 4. Situação do Plano Diretor dos Municípios Pólos Regionais e/ou com população superior a 20 mil habitantes do estado de São Paulo (1975)

\section{MAPAS}

Mapa 1. Região Administrativa de Franca

Mapa 2. Zoneamento de uso - Zonas comerciais, especiais e industriais.

Mapa 3. Mapa da Área Urbanizada e de Expansão Urbana proposta pelo Plano.

Mapa 4. Intervenções propostas no Sistema Viário. 116

Mapa 5. Áreas para fins paisagísticos e produção hortigranjeira. 118

Mapa 6. Localização do Distrito Industrial. 


\section{SUMÁRIO}

INTRODUÇÃO

1. PLANEJAMENTO URBANO NOS ANOS 60: EMPRESAS DE CONSULTORIA FAZEM OS PLANOS DIRETORES PARA O SERFHAU

Estratégias de sobrevivência à ditadura: por detrás do GPI - Grupo de Planejamento Integrado

Planejamento durante o regime militar: centralização política e o surgimento do SERFHAU

O papel do SERFHAU no financiamento e elaboração dos planos diretores de desenvolvimento integrado

A inclusão de Franca no financiamento dos planos diretores de desenvolvimento integrado pelo SERFHAU

A crítica generalizada ao Plano Diretor como peça de ficção

\section{O LONGO PROCESSO DE ELABORAÇÃO E IMPLEMENTAÇÃO} DO PLANO DIRETOR DE FRANCA

A aprovação da lei do Plano Diretor

O Plano Diretor no centro do debate político

\section{PLANO DIRETOR FÍSICO DE 1972: MODELO DE RACIONALIDADE TÉCNICA?}

O diagnóstico: interpretação realista da cidade

A política de desenvolvimento físico: base das propostas para a cidade e seu futuro industrial

As propostas do Plano Diretor Físico: o controle da expansão urbana e o zoneamento de uso e ocupação do solo

As propostas do Plano Diretor Físico: modernização da circulação e do sistema viário

As propostas do Plano Diretor Físico: expansão dos equipamentos públicos

A lei do Plano Diretor Físico: conteúdo abrangente e articulado 


\section{O PLANO DIRETOR DE FRANCA: DO PAPEL À PRÁTICA}

Contexto e efetividade do Plano Diretor de Franca

A industrialização paulista e as idéias sobre distritos industriais

A gênese do Distrito Industrial de Franca

Intervenções no sistema viário: preparando a cidade para sua expansão horizontal

O centro da cidade para os pedestres

Um parque na área central: o Vale dos Bagres

Transformando voçorocas em áreas urbanizadas

- Voçoroca do Parque São Jorge

- Voçoroca das Maritacas

- Voçoroca da Vila Catocos

- Voçoroca da Vila Monteiro

- Voçoroca da Boa Vista 169

- Voçoroca do Pestalozzi 170

- Voçoroca do Jardim Conceição Leite

- Voçoroca da Vila Raycos

- Voçoroca da Ponte Preta

- Voçoroca da Vila Planalto

- Voçoroca da Vila Samelo

- Voçoroca da Vila Palmeiras

- Voçoroca da Manoel Valim

- Voçoroca da Scarabucci

- Voçoroca do Quirino

- Voçoroca do Chiné

- Voçoroca de Higienópolis

- Voçoroca de Adalgisio Leite

- Fundo de vale do Córrego dos Bagres

- Área entre loteamentos Jardim Francano e Vila Roselândia e a Av. Rio Branco

ANEXOS

Anexo 1 - Legislação 


\section{INTRODUÇÃO}

A cidade de Franca está situada no extremo nordeste paulista. Seu surgimento está vinculado ao movimento de "torna-viagem" dos mineiros, na feliz expressão de Carlos Lemos (LEMOS, 1976), no final do século XVIII, quando fugindo dos impostos da Coroa Portuguesa, foram ocupando o oeste de Minas até a rota do Anhanguera, o chamado "Caminho dos Goyazes", a velha estrada entre o porto de Santos e as províncias de Goiás e Mato Grosso. Rota dos comboios de sal e gado, ao longo do seu trajeto foram surgindo pousos e vilarejos.

A Vila Franca, surgida neste caminho, traz na sua gênese uma questão inicial que vem sendo discutida por historiadores: a existência ou não de um Plano urbanístico já na sua criação. Segundo PUGLIESE (1967), a possibilidade de existência de um plano urbanístico, atribuído ao alferes Manoel Marques de Carvalho é remota, já que seus reflexos efetivos no espaço não puderam ser claramente observados. Seria apenas um desenho da região central da cidade, que teria um formato de cruz, com uma igreja em cada uma de suas pontas e a matriz no centro. Já BENTIVOGLIO (1997), baseado em documentos cartorários e de propriedades urbanas, afirma que o plano em formato de cruz existiu, mas não teve seqüência, foi deturpado quando da efetiva ocupação dos espaços demarcados para a ocupação urbana.

O fato é que, havendo ou não o plano, ou mesmo a intenção do plano, os estudos não apontam influência relevante sobre o espaço da cidade. $O$ pequeno povoado desencadeou um processo de expansão urbana mais consistente a partir do momento em que se iniciou a inserção da região na economia cafeeira e consequentemente da construção e expansão da rede ferroviária, o que ocorre de forma mais marcante desde a década de 1880. Já nesta época tem início uma incipiente indústria coureira, vinculada à facilidade de obtenção da matéria-prima propiciada pela atividade pecuária regional e pelos comboios de gado que vinham do interior de Mato Grosso e Goiás. Logo em seguida, no início do século $\mathrm{XX}$, a possibilidade de escoamento das mercadorias pela ferrovia ensejou o surgimento da indústria calçadista, a partir da base de produção já instalada, decorrente da fabricação de produtos de couros para tropeiros e para as próprias fazendas, como arreios, selas, botinas, e outros objetos úteis confeccionados em couro. A primeira 
experiência de maquinização, realizada a partir de 1921, pela fábrica de calçados Jaguar, ainda que fracassada (a empresa foi à falência em 1924) propiciou a formação de mão de obra especializada e tornou visível as amplas possibilidades de expansão industrial decorrentes da produção seriada. Foi principalmente a partir do fechamento da fábrica Jaguar que se iniciou a criação de novas empresas calçadistas, em parte por ex-funcionários da empresa que passaram a dominar o ofício. Embora até o final da II Guerra esta atividade ainda fosse pouco expressiva para a economia local, voltada principalmente para a produção agrícola e pastoril, combinando sua bacia leiteira aos cafés finos, a produção de calçados foi o ponto de partida para a industrialização. Esta situação somente vai se modificar a partir de meados dos anos 50, quando se inicia um novo e modernizante ciclo industrial na cidade, principalmente nos anos JK. (FERREIRA, 1989)

No início da década de 1960 a cidade passa por um acelerado processo de expansão urbana, cuja decolagem está ligada umbilicalmente ao processo de industrialização calçadista, que modernizou seu parque produtivo e seus processos de trabalho, permitindo a produção e exportação massiva de calçados que tornou a cidade o segundo maior pólo produtor de calçados do país. Em 2006, sua populaçãojá atingia 328.121 habitantes, segundo as estimativas do IBGE (DOU 31/08/2006), com 760 unidades industriais do setor calçadista em funcionamento (Censo da indústria calçadista de Franca, UniFacef/IPES, setembro de 2005), com uma expressiva produção de 25,5 milhões de pares de calçados em 2006.

Tabela 1. Produção anual de calçados de Franca (em milhões de pares)

\begin{tabular}{|l|l|}
\hline Ano & Pares \\
\hline $\mathbf{1 9 8 4}$ & 32,0 \\
$\mathbf{1 9 8 5}$ & 30,0 \\
$\mathbf{1 9 8 6}$ & 35,0 \\
$\mathbf{1 9 8 7}$ & 17,0 \\
$\mathbf{1 9 8 8}$ & 24,0 \\
$\mathbf{1 9 8 9}$ & 27,0 \\
$\mathbf{1 9 9 0}$ & 27,0 \\
$\mathbf{1 9 9 1}$ & 24,0 \\
$\mathbf{1 9 9 2}$ & 25,7 \\
$\mathbf{1 9 9 3}$ & 31,5 \\
$\mathbf{1 9 9 4}$ & 31,5 \\
$\mathbf{1 9 9 5}$ & 22,0 \\
\hline
\end{tabular}

\begin{tabular}{|r|r|}
\hline Ano & Pares \\
\hline $\mathbf{1 9 9 6}$ & 24,8 \\
$\mathbf{1 9 9 7}$ & 29,0 \\
$\mathbf{1 9 9 8}$ & 29,0 \\
$\mathbf{1 9 9 9}$ & 29,5 \\
$\mathbf{2 0 0 0}$ & 32,5 \\
$\mathbf{2 0 0 1}$ & 32,5 \\
$\mathbf{2 0 0 2}$ & 30,0 \\
$\mathbf{2 0 0 3}$ & 32,1 \\
$\mathbf{2 0 0 4}$ & 35,4 \\
$\mathbf{2 0 0 5}$ & 27,9 \\
$\mathbf{2 0 0 6}$ & 25,5 \\
& \\
\hline
\end{tabular}

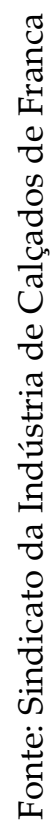

O município atraiu trabalhadores que, apesar de residirem nas cidades vizinhas, encontram postos de trabalho no setor industrial. Além disso, suas atividades no setor de calçados, café, comércio e serviços tem efeito sobre os demais municípios da região, que a utilizam para fazer compras, ou ter acesso a serviços de saúde e educação. $\mathrm{O}$ entorno da cidade desenvolveu uma agricultura moderna e articulada à indústria, principalmente as agroindústrias de açúcar e álcool. A taxa geométrica de crescimento anual da população foi superior à média do Estado entre 1991 e 2000 (2,52\% contra 2,12 ). Além de importante pólo calçadista, a cidade tornou-se o maior núcleo exportador 
de calçados masculinos do país. A presença da indústria atraiu curtumes, indústrias de borracha, de processamento de couros e de colas, produzindo um cluster do setor calçadista. A indústria local concentra $6 \%$ da produção nacional de calçados masculinos, exportando cerca de 30\% de sua produção (SÃO PAULO, 2006).

A população da cidade saltou de 56.987 habitantes (47.244 na zona urbana) em 1960 para 86.420 em 1970, em grande parte drenada das pequenas cidades paulistas e mineiras de seu entorno,como Pedregulho, Cristais Paulista, Patrocínio Paulista, Itirapuã, Ibiraci, Claraval, Capetinga e Cássia, dentre outras.

\section{REGIÃO ADMINISTRATIVA DE FRANCA}

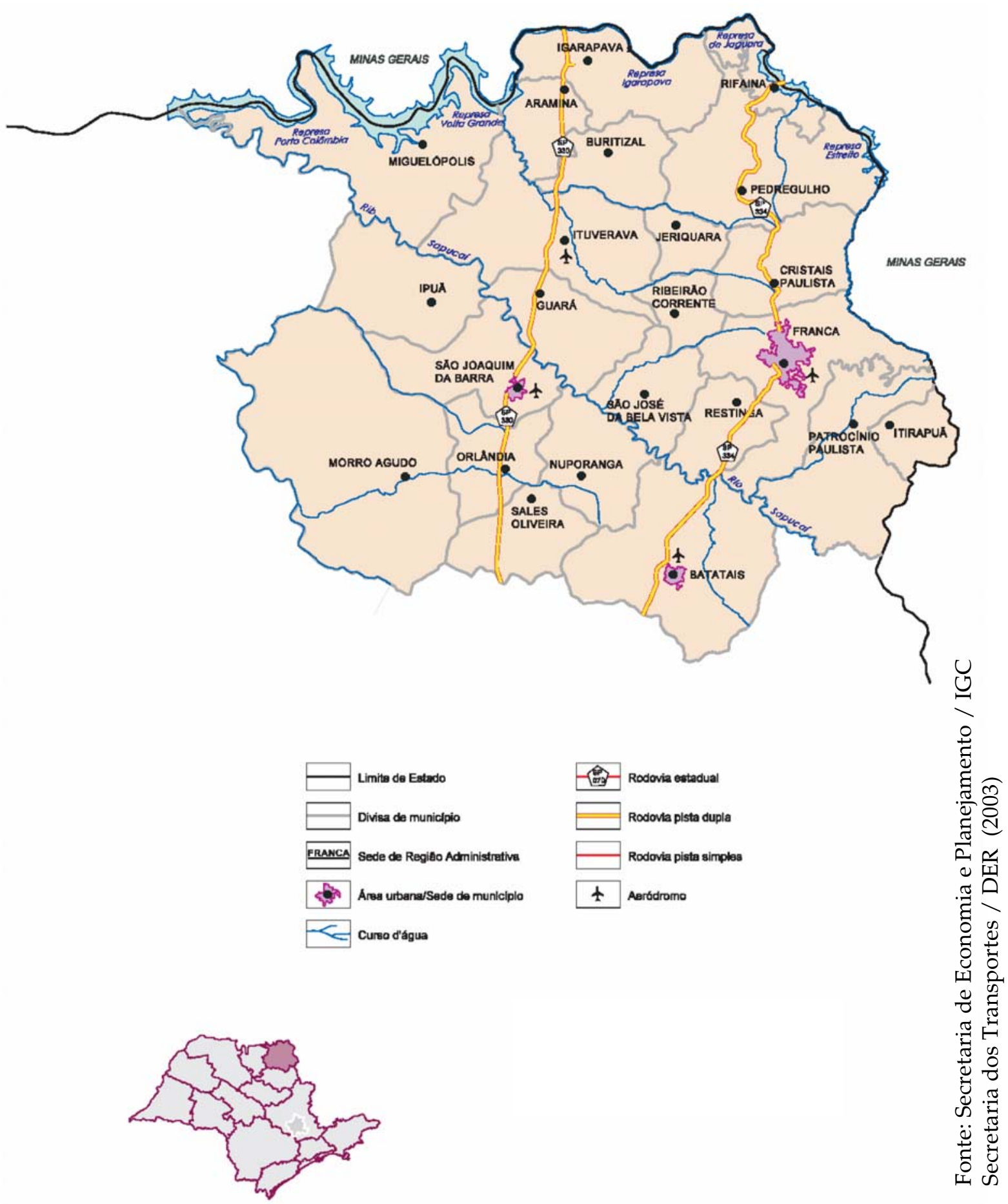


Como parte deste processo de grandes transformações em sua economia (antes agrícola, agora industrial) ocorre um outro fenômeno: o de urbanização e de abertura de novos espaços para loteamentos sem precedentes: entre 1965 e 1975, surgiram 41 novos loteamentos privados ${ }^{1}$, com uma área loteada de aproximadamente 707 hectares, quase duplicando a área da cidade existente (até então). Deste processo de urbanização resultou que as regiões centrais e mais antigas fossem sendo paulatinamente melhoradas, principalmente recebendo obras de pavimentação, infra-estrutura e equipamentos públicos.

Portanto, foi neste período que ocorreu uma urbanização em ritmo acelerado, tendo a industrialização como a força motriz de um processo de rápida expansão urbana. Foi também neste momento que o Poder Público local resolve elaborar um Plano Diretor de Desenvolvimento Integrado - PDDI, paradigma do planejamento urbano daquele período.

Tal como propõe SOUZA (1988b), podemos compreender o planejamento urbano como um processo político de tomada de decisões sobre as prioridades da urbanização, decisão que vai se estabelecer através de políticas urbanas. A política urbana pode ser entendida também como a manifestação do processo de planejamento urbano que ocorre nas cidades via projetos de intervenção, de ações urbanísticas de controle e de execução de obras públicas e privadas, explicitadas numa ordem de prioridades, o que consolida a necessidade de estabelecer mecanismos de escolha e compromissos, inclusive orçamentários.

Para realizar os serviços deste Plano Diretor, que consideramos o primeiro que a cidade colocou em prática, já que permanecem dúvidas sobre a real concretude do plano em cruz na criação da cidade ainda no século XIX, a Prefeitura Municipal contratou uma empresa privada de consultoria, o GPI - Grupo de Planejamento Integrado, sediada em São Paulo e constituída, dentre outros objetivos, para elaborar planos diretores e atender as exigências do Serviço Federal de Habitação e Urbanismo - SERFHAU, criado pela lei federal 4.380, de 21 de agosto de 1964. Este organismo estatal era o responsável pela elaboração e coordenação da política nacional no campo do planejamento local integrado, inclusive para estabelecer as normas técnicas para a elaboração dos Planos Diretores municipais durante o período autoritário instituído após o golpe militar de 1964. Suas funções específicas foram regulamentadas em 1966, através do decreto federal $n^{\circ} .59 .917$, editado em 30 de dezembro, sendo suas principais tarefas a elaboração e coordenação das políticas nacionais de planejamento local integrado, através do estabelecimento de normas e roteiros para os planejadores, propostas de legislação, assistência técnica e difusão de experiências, dentre outras atribuições.

A metodologia preconizada pelo SERFHAU privilegiava um diagnóstico dos problemas urbanos e uma pretensa racionalidade na elaboração do Plano, cujos efeitos sobre o espaço urbano foram muito criticados por sua escassa eficácia, apontada por significativo número de trabalhos, tais como de AZEVEDO (1976), CINTRA e HADDAD (1978), RIBEIRO e CARDOSO (1990 e 1994), ROLNIK (1994), BONDUKI (2000), MARICATO (2001), e VILLAÇA (1999 e 2005). Nestes estudos, verifica-se que as críticas

${ }^{1}$ (CHIQUITO, 2006:53). 
se tornaram mais agudas na medida em que a oposição ao regime autoritário se ampliava, destacando-se dentre outros, os seguintes aspectos que, em maior ou menor grau, são recorrentes nos autores citados:

- a centralização de poder no Executivo;

- a ausência de participação da sociedade e dos usuários dos serviços públicos na definição dos investimentos e das políticas públicas;

- a ineficácia de um planejamento urbano considerado tecnocrático, baseado num diagnóstico excessivo, irreal, que se espelhava numa legislação elitista e na burocracia, incapaz de enxergar e diferenciar a cidade real daquela dos mapas;

Além disso, apontam os autores outros aspectos, como:

- a deterioração das condições de vida urbana e ambientais;

- a execução de grandes obras que interessavam mais às empreiteiras que às cidades;

- a priorização do transporte individual em detrimento do coletivo, principalmente através da construção de obras viárias para o automóvel particular;

Enfim, esta crítica afirma e reafirma que o planejamento do período seria apenas retórico, criação mental, seus planos seriam natimortos, sem qualquer desdobramento efetivo na cidade real.

No entanto, numa primeira observação empírica no espaço urbano da cidade de Franca, verifica-se a realização de intervenções físicas e obras cujos efeitos estão claramente presentes no território, cujos principais elementos estão contidos nos estudos e nas propostas do seu Plano Diretor desenvolvido pelo GPI, tais como:

- a criação do Distrito Industrial;

- a pedestrianização do centro;

- a implantação de um extenso e moderno sistema viário;

- a transformação de voçorocas em áreas verdes, de lazer e parques urbanos.

Além disso, ocorreu uma reorganização administrativa da Prefeitura local, que vinha sendo perseguida desde o início dos anos 60, que conformou e consolidou uma estrutura permanente de planejamento urbano na prefeitura de Franca. Ou seja, seu impacto não pode ser considerado desprezível sobre o espaço urbano e sobre a estrutura administrativa do poder público local, contrariando aspectos veementes e reiterados da crítica apontada na literatura disponível sobre o planejamento relativo ao período do SERFHAU.

A partir destas observações empíricas, o presente trabalho objetiva identificar as 
principais ações e proposituras previstas naquele Plano Diretor que foram implementadas e quais as condições políticas e econômicas que as viabilizaram, analisar sua importância para o desenvolvimento urbano do município e, em certo sentido, discutir em que medida a pretensa inefetividade do planejamento urbano do período, apontada pela literatura, pode ser constatada numa cidade do interior paulista como Franca. Ou seja, a crítica quase unânime que a literatura disponível tornou corrente e a sua generalização pode esconder aspectos importantes dos Planos Diretores realizados naquele período, se analisada com maior atenção e profundidade.

Trabalhamos, portanto, com uma hipótese geral durante o trabalho de pesquisa que considera que, embora aspectos reiterados da crítica aos Planos Diretores das décadas de 1960 e 1970 e à sua concepção tecnocrática não possam ser contestados, no caso específico de Franca, os sucessivos governos municipais eleitos após a sua aprovação, talvez não explicitamente, agiram segundo suas diretrizes principais em relação à produção do ambiente construído e aos investimentos públicos.

Queremos dizer com isso que o processo de elaboração do Plano permitiu estabelecer uma espécie de compromisso local, ou melhor, um conjunto de compromissos do governo municipal e de suas elites industriais para a expansão e o controle do espaço urbano; que a idéia da "modernização tecnocrática" difundida pelos setores técnicos vinculados ao regime militar e pela metodologia utilizada para a elaboração dos Planos Diretores do período do SERFHAU, de pretensa racionalidade da organização espacial ao se vincularem às idéias da "gerência científica" (padrão taylorista e fordista) do processo produtivo fossem a contrapartida da organização do espaço industrial e da cidade, ou seja, os sistemas de controle do processo produtivo dentro das fábricas, tiveram como reflexo no espaço da cidade formas de produção e ocupação territorial similares. Mais ainda, verificamos que algumas propostas que eram locais, do próprio governo ou de setores empresariais foram incorporadas pelo Plano de Franca, tornando-o mais adequado ao que pretendiam para a cidade.

Então aquilo que se propunha no Plano Diretor, como infra-estrutura geral da cidade (de uma concepção de cidade "racional" para a acumulação capitalista), em relação ao sistema viário, aos locais para instalação da indústria e comércio, era o que o capital industrial calçadista necessitava para sua acumulação e expansão, o que motivaria sua defesa e aplicação pelos setores dominantes locais, diferentemente da crítica que se atribui de modo generalizado à maioria das cidades que fizeram seus Planos Diretores à época, que a literatura afirma não terem sido utilizados ou que eram distantes da realidade local, tornando-se papel pintado nas gavetas das Prefeituras.

Desta maneira, mostrou-se necessário pesquisar o processo de implantação e elaboração do Plano, quais foram de fato as principais diretrizes físicas do Plano Diretor e verificar quais foram implementadas, ou seja, localizar onde realmente ocorreu a aplicação dos elementos do Plano Diretor e de suas principais propostas sobre o ambiente construído da cidade, discutir qual era o discurso de sua necessidade ou prioridade e qual o impacto que tiveram na organização espacial da cidade atual, já que, como afirmamos anteriormente, diversos aspectos abordados no diagnóstico e na Lei do Plano 
Diretor, no que se refere ao sistema viário, à expansão urbana, à industrialização, às áreas de lazer, estão hoje presentes no cenário urbano de Franca.

A pesquisa tomou como ponto de partida os estudos realizados e publicados nos cinco volumes do Plano Diretor de Desenvolvimento Integrado de Franca, que apresentam o diagnóstico, a política de desenvolvimento físico, o projeto de lei, o projeto do distrito industrial e o plano de ação do governo para implementar o Plano. Desta forma, pudemos mapear as principais idéias e propostas presentes no Plano, o que nos levou também a buscar informações sobre o papel desempenhado pela empresa de consultoria, o GPI neste processo.

Estes dados foram complementados por pesquisa na legislação posterior e nas alterações da lei do Plano. A pesquisa documental procurou abranger ainda atas da câmara municipal e noticiário dos jornais diários locais, traduzindo os debates ocorridos ao longo do tempo sobre o planejamento urbano da cidade, bem como a localização de imagens urbanas do período. Localizamos e entrevistamos ainda, após uma longa investigação, os principais envolvidos com o objeto de pesquisa - os sócios e técnicos do GPI, técnicos e secretários de planejamento da Prefeitura de Franca e ex-prefeitos da cidade. As bases conceituais foram fornecidas pelo material bibliográfico pertinente, livros, artigos, teses e dissertações relativos ao período estudado, ao planejamento em geral, ao planejamento urbano e à cidade de Franca, como um estudo de caso, num permanente diálogo com a crítica existente.

Tais elementos permitiram configurar a pesquisa de acordo com quatro eixos estruturantes, também presentes no texto: o primeiro se refere ao processo de elaboração do Plano Diretor de Franca segundo a metodologia do SERFHAU e aquela utilizada pelo GPI. O segundo se refere à história do GPI, a empresa de consultoria do Plano de Franca e ao caráter que assumiu nos duros tempos da ditadura, como estratégia de sobrevivência de membros da oposição política ao regime militar. O terceiro se refere ao longo processo que permitiu a implantação e realização de significativa parcela das proposições do Plano. O quarto apresenta o que se realizou do Plano, suas razões e seu impacto sobre a cidade.

Considerando que somente em 1997 - vinte e cinco anos depois da transformação do Plano em lei - iniciou-se a elaboração de um outro Plano Diretor para a cidade, com a eleição pela primeira vez de um governo do Partido dos Trabalhadores - PT, cujo padrão pode alinhar-se à corrente intitulada por RIBEIRO (1994) de reforma urbana redistributiva, torna-se relevante tanto para o poder público como para os diversos profissionais que atuam na produção do espaço urbano das cidades brasileiras em geral, em Franca em particular, o estudo de caso e a análise da real aplicação do Plano Diretor de 1972, até mesmo porque este novo Plano Diretor somente foi promulgado em 2003, já sob a égide do Estatuto da Cidade.

Através do estudo do conteúdo do Plano, do processo de sua elaboração e da sua repercussão na estrutura urbana de Franca, pretende-se colaborar para preencher uma evidente lacuna da historiografia local, assim como da historiografia do urbanismo brasileiro num momento de superação do modelo de Plano Diretor de Desenvolvimento Integrado. Este trabalho se vincula a um conjunto de pesquisas sobre o período SERFHAU, concluídas e em andamento no Programa de pós-graduação em Arquitetura 
e Urbanismo da Escola de Engenharia de São Carlos².

Além disso, este trabalho pretende contribuir para o debate que nesse momento envolve urbanistas, historiadores, arquitetos, políticos, técnicos e cidadãos na elaboração de novos instrumentos e mecanismos de desenvolvimento urbano, econômico e social, a partir da aprovação do Estatuto da Cidade, que reafirma o Plano Diretor como instrumento principal para o planejamento democrático das cidades brasileiras.

Há ainda um outro aspecto que me leva a procurar seu desvendamento, para além de simplesmente tentar identificar as ações previstas no Plano Diretor que se tornaram realidade: meu próprio e direto envolvimento com o Plano Diretor de Franca, desde que me formei em arquitetura e urbanismo em 1974, quando iniciei uma participação na vida política e profissional da cidade que se estende até os dias de hoje, como dirigente de instituições públicas, de entidades profissionais, como professor, pesquisador, militante político e, fundamentalmente, como cidadão.

\footnotetext{
${ }^{2}$ A pesquisa em andamento " Constituição e Atuação do SERFHAU" financiada pelo CNPq, coordenada pela profa. Dra. Sarah Feldman; as dissertações de Mestrado "Expansão Urbana e Meio Ambiente nas Cidades não Metropolitanas: o caso de Franca-SP", de Elisangela de Almeida Chiquito, 2006 e "Planos diretores de Goiânia, década de 60: a inserção dos arquitetos Luís Saia e Jorge Wilheim no campo do planejamento urbano", de Juliana Costa Motta, 2004, concluídas; a Tese de Doutorado "A inserção das grandes empresas privadas de engenharia no campo do planejamento urbano no período SERFHAU“, de Juliana Costa Motta, em andamento, orientadas pela profa. Dra. Sarah Feldman.
} 


\section{PLANEJAMENTO URBANO NOS ANOS 60: EMPRESAS DE CONSULTORIA FAZEM OS PLANOS DIRETORES PARA O SERFHAU}

Naquela tarde, quando fui conversar com o engenheiro civil Weber Drauzio David, servidor aposentado da Prefeitura de Franca, buscando informações e dados que pudessem me auxiliar a recompor a história da elaboração e implantação do Plano Diretor de Franca, uma coisa me surpreendeu e intrigou. Passados mais de trinta anos depois da conclusão dos trabalhos do Plano, ele se lembrou nitidamente de alguns nomes dos principais integrantes da equipe do GPI, a empresa de consultoria que havia elaborado o Plano.

Na entrevista, eu havia perguntado como tinha surgido a idéia de fazer um Plano Diretor para Franca, ele respondeu que "o pessoal do serviço municipal de água e esgoto vivia cobrando um Plano, pois a cidade estava crescendo, estavam surgindo indústrias, precisava de uma diretriz". Em seguida, citou nominalmente alguns dos integrantes da equipe do GPI, "o arquiteto Heitor Ferreira de Souza e um deputado federal comunista, o Diógenes de Arruda Câmara" 1 .

Ao apontar os nomes de Heitor Ferreira de Souza, um gaúcho formado na Faculdade de Arquitetura da USP - FAUUSP e principalmente de Diógenes de Arruda Câmara, o depoimento de David começou a lançar luz sobre um aspecto até então bastante desconhecido do Plano Diretor de Franca. Ao entrevistá-lo, eu tinha poucas informações sobre Diógenes, a não ser algumas de caráter geral, como a que havia sido um importante dirigente do Partido Comunista Brasileiro, o PCB e, posteriormente,

\footnotetext{
${ }^{1}$ Informações obtidas em entrevista realizada pelo autor com o engenheiro aposentado da Prefeitura de Franca, Weber
} Drauzio David, em 05/08/2003. 
um dos fundadores do Partido Comunista do Brasil, o PC do B. Eu não poderia suspeitar que ali se encontrava o fio de Ariadne de uma bela e triste história dos anos de chumbo da ditadura militar, pouco conhecida.

Como nos volumes editados do Plano Diretor os únicos nomes que apareciam eram os de Heitor, como arquiteto responsável pelos mapas que ilustram o Plano, e de Aziz Ab'Saber, com seu trabalho sobre as voçorocas de Franca, comecei a puxar o novelo por ali. Foi quando se revelou o uso poderoso da internet como ferramenta para localizar as pessoas: a primeira pista encontrada foi o currículo de um consultor de empresas, Carlos Walter Aumond, que ostentava sua passagem pelo GPI. A partir das informações que Aumond forneceu, fui lentamente localizando os outros, inclusive Heitor Ferreira de Souza e Mário Alves de Melo, que muitos ex-colegas do GPI desconheciam o paradeiro, sequer se estariam vivos.

\section{ESTRATÉGIAS DE SOBREVIVÊNCIA À DITADURA: POR DETRÁS DO GPI - GRUPO DE PLANEJAMENTO INTEGRADO}

Para falar sobre o GPI, é fundamental lembrar a conjuntura política daqueles anos tumultuados da década de 1960. A repressão aos opositores do regime militar, iniciada nos primeiros dias do golpe que havia deposto o governo constitucional de João Goulart em abril de 1964, principalmente os comunistas, tornou-se uma política de Estado e viria a se acirrar a partir da edição do Ato Institucional n ${ }^{\circ} .5$, em dezembro de 1968, com a suspensão do "habeas corpus" e dos chamados direitos individuais. A perseguição, cassação, prisão, tortura e assassinato de professores, estudantes, militantes e intelectuais de esquerda tornou-se política oficial, levando muitos à clandestinidade e ao exílio. (COUTO,1998)

Mais recentemente, foram divulgados os conteúdos de gravações que dão conta que até o próprio presidente Geisel, um dos artífices do processo de descompressão política e da anistia, conhecia e aprovava a eliminação física dos opositores do regime, "matar é uma barbaridade, mas tem que ser". Ou seja, a perseguição e eliminação física dos oposicionistas era uma política de Estado, o que tornava a sobrevivência das pessoas perseguidas fora da clandestinidade ou do exílio tarefa difícil. (GASPARI, 2003)

No final do primeiro governo da ditadura, presidida por Castelo Branco, depois de algum tempo de refluxo por conta da fragilidade revelada com a queda do governo de Goulart, o ano de 1967 marcou também uma série de divórcios e rupturas no campo das organizações e agrupamentos de esquerda. Após o desastre político de 1964, quando o governo constitucional caiu quase sem resistência popular, o principal partido de esquerda no Brasil da época, o PCB (Partido Comunista Brasileiro), fragmentou-se em diversos agrupamentos menores, em meio às constantes avaliações negativas sobre o fracasso de sua linha política, recriminações e autocríticas de seus membros. O Partido, ainda liderado pelo legendário Luis Carlos Prestes, continuava a defender a formação de uma frente democrática (que incluía setores da chamada burguesia liberal) contra a ditadura, atuando por vias pacíficas e dentro dos estreitos limites impostos pelo governo, pela derrubada do regime militar. Insistindo que havia sido exatamente esta política 
considerada conciliatória a grande responsável pelo fracasso de 1964, muitos dirigentes e militantes descontentes com os rumos tomados pelo partido, resolveram sair do PCB e fundar seus próprios grupos, que por sua vez logo se fragmentavam em outros. Carlos Marighela, uma das principais lideranças clandestinas comunistas, logo após participar da assembléia da Organização Latino-Americana de Solidariedade (OLAS) em Havana (Cuba), fundou a Ação Libertadora Nacional (ALN). A proposta básica da ALN era iniciar um processo de guerrilha urbana a fim de conseguir recursos para a formação de uma guerrilha rural, base de um futuro "Exército de Libertação Nacional", que deveria derrubar o regime militar. Outro grupo importante, fruto de uma dissidência do PCB ocorrida antes mesmo do golpe, em 1962, era o Partido Comunista do Brasil (PC do B). A partir de 1967, inspirado em outro tipo de tática revolucionária, próxima do que os chineses liderados por Mao Tse Tung haviam feito no final dos anos 1940, o PC do B decidiu montar uma base guerrilheira no norte do país, na região do Araguaia, enviando para lá mais de sessenta militantes que seriam treinados como guerrilheiros e deveriam constituir focos de ação armada. A tática proposta pelo PC do B era a de explorar os conflitos pela posse da terra, bastante comuns na região e, a partir daí, organizar um exército com os moradores da região que deveria desencadear uma "guerra popular prolongada", criando "zonas liberadas", até a derrubada do governo militar e do regime vigente. Localizada pelos serviços de segurança por volta de 1972, as bases estabelecidas pelo PC do B para a guerrilha rural foram violentamente atacadas por grandes unidades de tropas do exército, através de uma verdadeira operação de guerra desencadeada na região de Xambioá, no Araguaia, que terminou por dizimar os últimos guerrilheiros por volta de 1975. (NAPOLITANO,1998:28)

Diante deste quadro, resultam com nitidez e obviedade as dificuldades para a sobrevivência dos agrupamentos de esquerda, a dificuldade em obter trabalho para muitos técnicos e profissionais militantes, vinculados ou simpatizantes aos partidos de esquerda ou simplesmente de oposição. Nestas circunstâncias, pois tolhida a liberdade de imprensa e de pensamento, a perseguição política abertamente instalada, inclusive dentro das próprias universidades públicas, com o afastamento e a aposentadoria compulsória de renomados professores e pesquisadores nas universidades e centros de pesquisa, poucos eram os caminhos que restavam para trilhar, como o exílio ou a resistência velada em instituições remanescentes, como foi o caso do CEBRAP - Centro Brasileiro de Análise e Planejamento, criado em 1969 por um grupo de professores universitários aposentados compulsoriamente. (COUTO, 1998)

Mas, a pesquisa revela que houve um outro caminho também, propiciado pela constituição de empresas privadas que pudessem obter financiamentos, geralmente públicos e vinculados ao SERFHAU, para o planejamento de obras ou atividades de planejamento e pesquisas urbanas, onde a presença de técnicos qualificados e especializados era necessária ao regime que se instalava e se fortalecia, como procuraremos demonstrar com a história do próprio GPI.

Esta hipótese tem sido reforçada por estudos recentes, como o fato que apenas 20\% das empresas cadastradas no FINEP para a realização de atividades ligadas à categoria desenvolvimento urbano, nos anos 1970, se constituíram antes da criação do SERFHAU, embora algumas empresas importantes, como o Consórcio Nacional de 
Engenheiros Consultores - CNEC e a HIDROSERVICE tenham sido criadas ainda nos anos 50. Mais ainda, que foi a regulamentação do SERFHAU que ofereceu as condições para que empresas de engenharia e consultoria se introduzissem no setor denominado "desenvolvimento urbano", elaborando planos diretores. Isto permitiu o crescimento das empresas privadas de engenharia, consultoria e projeto, como a SERETE, HIDROSERVICE, PROMON, mais tarde a HIDROBRASILEIRA, que vão desenvolver grandes e complexos projetos de engenharia para as obras de infra-estrutura que se destinavam a dar sustentação ao desenvolvimento econômico do país, como usinas hidroelétricas, linhas de metrô, rodovias, portos, aeroportos, obras de saneamento, pontes e viadutos. (FELDMAN, 2005b)

A modernização administrativa, os projetos e as obras do chamado "Brasil Grande" desejado pelos militares e seus aliados políticos, eram alguns dos objetivos dos novos donos do poder, e não podiam prescindir do conhecimento técnico profissional acumulado nas universidades e em setores do poder público para atingir suas metas de desenvolvimento do país, o que tornava necessário absorver quadros técnicos especializados, competentes e de alto nível.

Para isso, até mesmo por se tratar de uma exigência e característica do planejamento proposto pelo SERFHAU, estas empresas se organizaram internamente reunindo equipes multidisciplinares constituídas por equipes de engenheiros, arquitetos, engenheiros mecânicos, economistas, administradores, advogados, geólogos, sociólogos, dentre outros. No setor de planejamento territorial, agrupavam-se em unidades compostas de unidades de arquitetura e planejamento urbano, sociologia, economia, transportes, agricultura e organização de métodos, tendo como unidade auxiliar a fotointerpretação. (ZAHN, 1980 e VIZIOLI, 1998)

Estas empresas privadas vão incorporar quadros técnicos da universidade e dar suporte aos projetos do governo, assim como se reorganizam no âmbito do aparelho de Estado instituições voltadas para o planejamento, consideradas instrumento indispensável à atuação do Estado moderno, como secretarias de planejamento e fundações públicas voltadas para a ação planejada, como foram os casos do Centro de Estudos e Pesquisas de Administração Municipal - CEPAM, posteriormente Fundação Prefeito Faria Lima em São Paulo, criado em 1967 e da Fundação João Pinheiro em Minas Gerais, criado logo em seguida, em 1969.

Neste contexto, da necessidade do próprio regime militar, que entendia ser o planejamento ferramenta indispensável para seus ambicionados e ambiciosos propósitos de modernização do país e, ao mesmo tempo, da necessidade de sobrevivência econômica de técnicos perseguidos pelo regime, é que foi criado o Grupo de Planejamento Integrado Ltda. - GPI, na cidade de São Paulo, originalmente um produto da fusão de interesses econômicos e profissionais de alguns técnicos, para manter e ampliar um mercado de trabalho. Em parcela considerável ligados à esquerda oposicionista, liderados por alguns deles que não estavam na clandestinidade, estes técnicos mantiveram três empresas de consultoria que terminaram por se unir para poder elaborar o que, na época, era entendido como planejamento integrado ou compreensivo: um planejamento que abrangesse a própria estrutura administrativa do município, as condições econômicas e sociais para o desenvolvimento e a preparação 
do espaço físico da cidade para um crescimento harmônico e equilibrado de suas estruturas ${ }^{2}$.

Inicialmente, os manuais do SERFHAU exigiam a expressa participação destas empresas de consultoria na elaboração do Plano Diretor: a anamnese ou pesquisa da realidade local "deverá ser realizada por um escritório privado ou equipe técnica de consultoria, de acordo com as necessidades verificadas na área de trabalho e das deficiências de recursos humanos específicos para uma correta execução do Plano." (BRASIL-Minter,1968:14)

A pressão do governo federal sobre os municípios para elaborar os Planos gerou

"uma corrida na direção dos planos diretores, que se traduziu no mercado de trabalho técnico-científico pela instalação de um grande número de escritórios e empresas de planejamento. Algumas firmas dotadas de tradição e pioneirismo no setor, e que até então viviam em condições econômicas e financeiras mais ou menos críticas e certamente desestimulantes, passaram a ter um novo status, transformando-se em verdadeiras potências econômicas. Outras, menores, surgiram da noite para o dia, enfrentando a princípio dificuldades de todos os tipos. É importante assinalar que a falta de clientes dificultava a formação de bons grupos técnico-científicos, implicando em trabalhos de planejamento metodologicamente falhos, incompletos e deficientes." (AB'SABER,1969:21)

O depoimento de Heitor Ferreira de Souza ${ }^{3}$ possibilita-nos ter uma visão panorâmica do que ocorreu na época para a criação de uma empresa como o GPI, enquanto uma estratégia de sobrevivência econômica de um lado e, por outro, transformando-se até mesmo em estratégia de sobrevivência física para técnicos e militantes políticos perseguidos pelo regime.

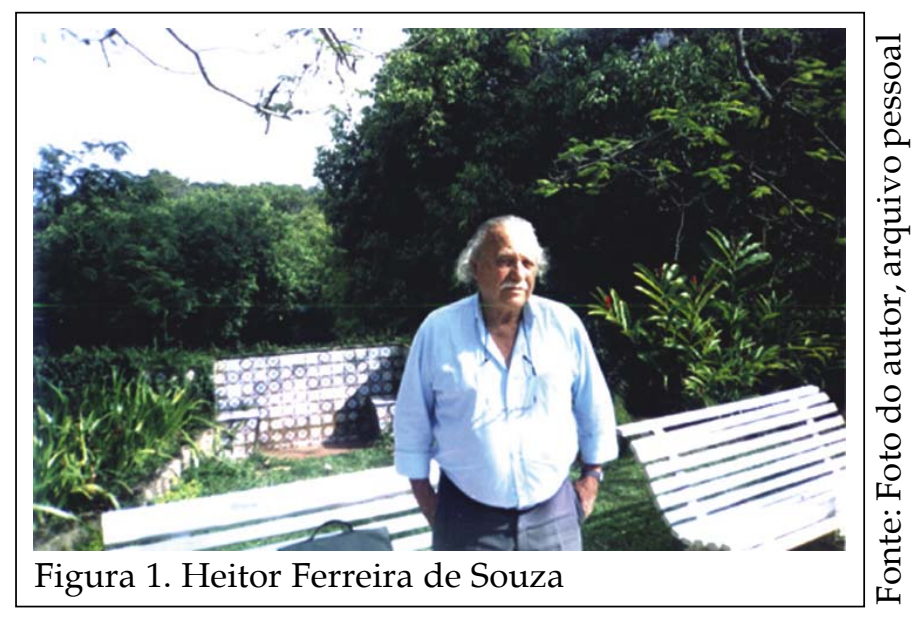

\footnotetext{
${ }^{2}$ As entrevistas realizadas com Heitor Ferreira de Souza e Mário Alves Melo permitem reconstituir a junção das empresas.

${ }^{3}$ Informações obtidas na entrevista fornecida ao autor e Sarah Feldman, em 11/11/2004.
} 
Para Heitor, a idéia inicial era abrir uma cooperativa de profissionais, mas que se revelou impraticável, pelas dificuldades burocráticas e falta de condições políticas para criar um organismo desta natureza naquele momento. Assim, ele optou por abrir uma empresa só no papel, em seu próprio nome e da mulher, Vera de Souza, que funcionava na prática como um escritório de arquitetura e urbanismo.

O escritório de Heitor funcionou inicialmente para obter os primeiros trabalhos de planejamento e para o primeiro contrato com o SERFHAU, que teria sido o Plano do Distrito Industrial de Santos. Foi aí que, segundo Heitor ${ }^{4}$,

"apareceu um cara que marcou muito a minha formação, que era o Diógenes de Arruda Câmara, quem levou ele lá foi o Paesani ${ }^{5}$, também ligado ao partido, o Arruda tinha vindo, pra disfarçar, de padre, o Arruda estava sendo perseguido, depois do Prestes era ele, o segundo homem do Partidão. Ele tava ligado ao Marighella. Então o Arruda aparece e tem que se esconder, e como o apartamento era grande, tinha uma certa folga, eu o abriguei lá, arranjei uma cama, num canto de uma sala, tinha armário e tudo. Aí, ele se instalou, embaixo tinha uma pastelaria chinesa e a gente montou um esquema lá, que subia pastel pro homem. E ele ficou lá".

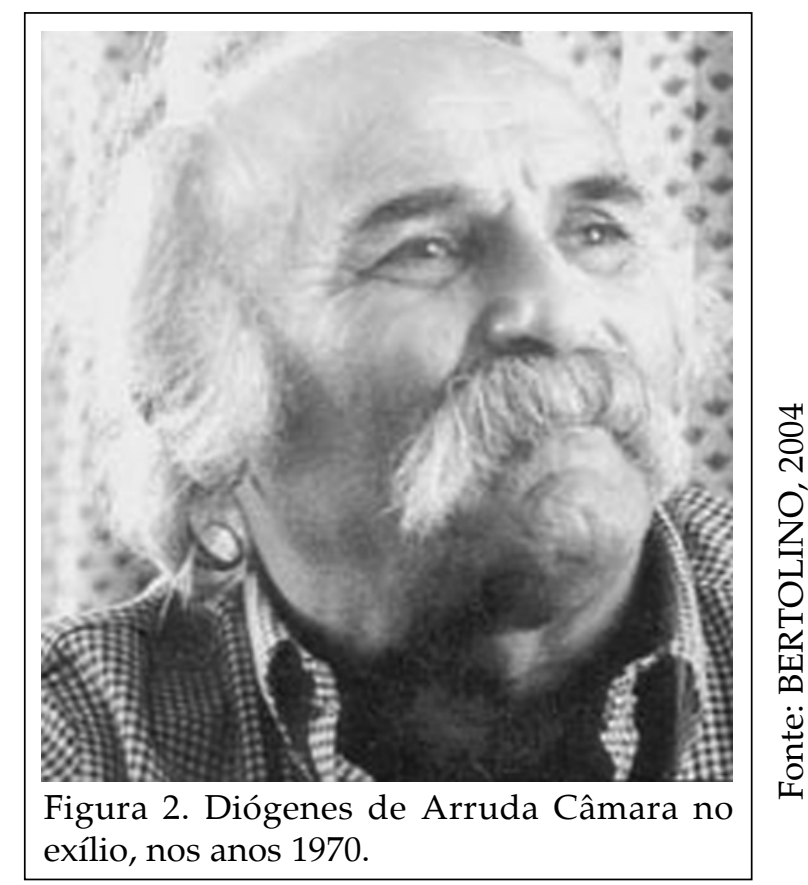

Com a chegada de Arruda Câmara ${ }^{6}$ e da PLANORG, empresa constituída pelos sócios e administradores públicos, especialistas em organização e métodos administrativos, o pernambucano Mário Alves Melo, que havia sido funcionário da prefeitura do Recife e do IBAM, e Otávio Gonçalves de Oliveira, que havia sido prefeito

\footnotetext{
${ }^{4}$ Depoimento gravado concedido ao autor e Sarah Feldman em 11/11/2004, Rio de Janeiro - RJ.

${ }^{5}$ Alfredo Paesani, arquiteto, foi fundador e o primeiro presidente do Sindicato dos Arquitetos do Estado de SP, era ligado ao Partido Comunista Brasileiro - PCB.

${ }^{6}$ Em seu depoimento, Heitor afirma que Arruda Câmara, que tinha sido deputado federal, informou que tinha facilidade em trabalhar com leis, por causa de sua experiência de trabalho legislativo, que poderia ajudar nesta área.
} 
nomeado de Macapá, no então território do Amapá, foi que nasceu o embrião do GPI, que procurava desenvolver o chamado planejamento integrado, envolvendo a reorganização administrativa das prefeituras, o planejamento físico-territorial e as questões de desenvolvimento econômico e social.

Neste período inicial, quando ainda não existia formalmente o GPI, a PLANORG atuou conjuntamente com o escritório de Heitor nos planos diretores de Mogi-Guaçu e Ourinhos, cidades do interior paulista.

O GPI foi o resultado, no final, de um processo que resultou, em 1967, na união de três pequenas empresas, a ECPLAN - Economistas e Planejadores Associados Ltda. uma empresa voltada para análises econômicas, o escritório de arquitetura e urbanismo de Heitor, na verdade praticamente uma empresa voltada para o planejamento físico e espacial e a PLANORG, uma empresa voltada para o desenvolvimento de organização e métodos administrativos. Ou seja, como o planejamento integrado a ser contratado pelas normas do SERFHAU abarcava um horizonte bastante amplo dos chamados "problemas urbanos", e ainda com um foco específico na reorganização administrativa das prefeituras, as três empresas, que trabalhavam com questões que poderiam se tornar complementares nos pacotes de contrato, por uma facilidade operacional, decidiramse pela união ${ }^{7}$.

A ECPLAN pertencia a Diógenes de Arruda Câmara, que era uma das principais lideranças semi-clandestinas do Partido Comunista do Brasil - PC do B, que mantinha uma permanente preocupação com sua segurança, pois naquele momento se iniciava a articulação do processo de resistência armada ao regime militar. Seus sócios eram Calil Chade, ex-vereador pelo PCB em São Paulo e também dirigente do PC do B na época, e a Luiz Paulo Rozemberg. Formalmente, no entanto, a parte de Diógenes era representada por seu filho Marcos Paraguassu de Arruda Câmara e por sua companheira, a artista plástica Terezinha Costa Rego. ${ }^{8}$

O escritório de arquitetura era propriedade do arquiteto Heitor Ferreira de Souza, que posteriormente associado ao arquiteto Jairo Farias e Sérgio Zarattin criaria a POLO em 1969, uma outra empresa, mas esta não era formalmente ligada ao GPI, apenas Heitor, como pessoa física o era, através do seu escritório de arquitetura. A PLANORG era propriedade de Mario Alves de Melo e Otávio Gonçalves de Oliveira, ambos formados em administração pública pela Universidade Federal do Recife e pela Fundação Getúlio Vargas do Rio de Janeiro, respectivamente. Na verdade, segundo o depoimento de Melo, esta empresa havia sido criada em 1963, para elaborar todas as leis, regulamentos, manuais, procedimentos para o recém-criado Estado do Acre, pois Mario e Otávio haviam sido contratados pelo seu governador José Augusto de Araújo para estruturar a ação do novo Estado. No final de 1966, com o final do contrato e da gestão de Araújo, os dois sócios decidiram buscar novas frentes de trabalho. Conforme o depoimento de Melo, foi naquele ano de 1966 quando reencontrou Arruda, a quem conhecia desde os tempos do Recife, quando foi secretário de Administração, no segundo

\footnotetext{
${ }^{7}$ Informações obtidas nas entrevistas efetuadas com Heitor Ferreira de Souza (24/11/2004, Rio de Janeiro-RJ), Carlos Walter Aumond (23/07/2004, São Paulo-SP) e Mario Alves de Melo (12/03/2007).

${ }^{8}$ Atualmente, Marcos Paraguassu de Arruda Câmara é docente e pesquisador da FAUBA, tendo se formado em arquitetura após o seu retorno do exílio, no final da década de 1970. Terezinha Costa Rego vive no Recife.
} 
governo do prefeito Pelópidas Silveira $(1955-1959)^{9}$, substituído por Miguel Arraes no final de 1959.

Melo descreve como conheceu Arruda da seguinte maneira:

"eu era funcionário de carreira da Prefeitura do Recife e havia deixado a Secretaria de Administração, no segundo governo do Pelópidas Silveira, eleito vice-governador e substituído por Miguel Arraes, que me convidou a permanecer. Declinei do convite porque tinha conseguido uma bolsa de estudos, mas fiquei ainda uns dois ou três meses como secretário, enquanto o Arraes conseguia um substituto. Fui procurado pelo Diógenes Arruda Câmara, creio que por indicação do nosso amigo comum Paulo Cavalcanti, comunista histórico, promotor público e pessoa da maior integridade, que havia sido meu companheiro de secretariado, exercendo a pasta de Finanças. O Arruda havia deixado as altas funções que exercia na direção do Partido Comunista e convencera Arraes a elaborar um plano de desenvolvimento integrado para o Recife, no que dava mostra do seu pioneirismo, influenciado, quem sabe, pelo sistema adotado na União Soviética. Sabendo-me disponível, o Arruda queria que eu o ajudasse na coordenação do projeto, para o qual ele estava selecionando técnicos, alguns de prestígio internacional, como o geógrafo francês Michel Rochefort" ${ }^{\prime 10}$

No entanto, logo depois, em setembro de 1960, Melo viajou para os Estados Unidos com a bolsa de estudos na Universidade de Pittsburgh, (Administrative Management Program) e, quando voltou, em 1961, o projeto de Arruda havia sido descartado por Arraes. Convidado por Diogo Lordello de Mello, dirigente do Instituto Brasileiro de Administração Municipal - IBAM, Mario transferiu-se para o Rio de Janeiro para trabalhar na assessoria técnica do Instituto. Foi por este motivo que conheceu Otávio Gonçalves de Oliveira, então prefeito de Macapá. Através do contrato do IBAM para a reorganização administrativa da Prefeitura, acabou tornando-se posteriormente seu sócio com a criação da PLANORG.

Em 4 de dezembro de 1967, com a perspectiva de realizar novos trabalhos através dos financiamentos a serem obtidos junto do SERFHAU para o planejamento urbano e Planos Diretores, foi constituído formalmente o GPI: o capital inicial era de NCr $\$ 3.000,00$ (três mil cruzeiros novos), subscritos em três partes iguais, da PLANORG Planejamento e Organização Ltda., ECPLAN - Economistas e Planejadores Ltda. e Heitor Ferreira de Souza. A sociedade seria gerida pela PLANORG, com poderes de uso da denominação social, representação e outros. Seus objetivos eram "a obtenção de serviços técnicos profissionais para os seus associados, relativos a pesquisa e planejamento econômico social, físico, administrativo e financeiro". ${ }^{11}$

\footnotetext{
${ }^{9}$ Pelópidas Silveira era engenheiro. Foi prefeito do Recife por três vezes. Na última delas, eleito por uma aliança PSBPTB e apoiado pelo clandestino PCB, não concluiu o mandato, foi cassado em 10 de abril de 1964, logo após o golpe militar.

${ }^{10}$ Informações obtidas em entrevista concedida por Mario Alves Melo ao autor em 12/03/2007.

${ }^{11}$ Dados extraídos do contrato social do GPI, publicado no Diário Oficial do Estado de SP, 11 de dezembro de 1967. O valor do contrato deve ser pro-forma, uma vez que atualizado monetariamente resultaria hoje em apenas $\mathrm{R} \$ 3.870,00$ (conforme tabela de atualização monetária do Tribunal de Justiça do Estado de SP).
} 


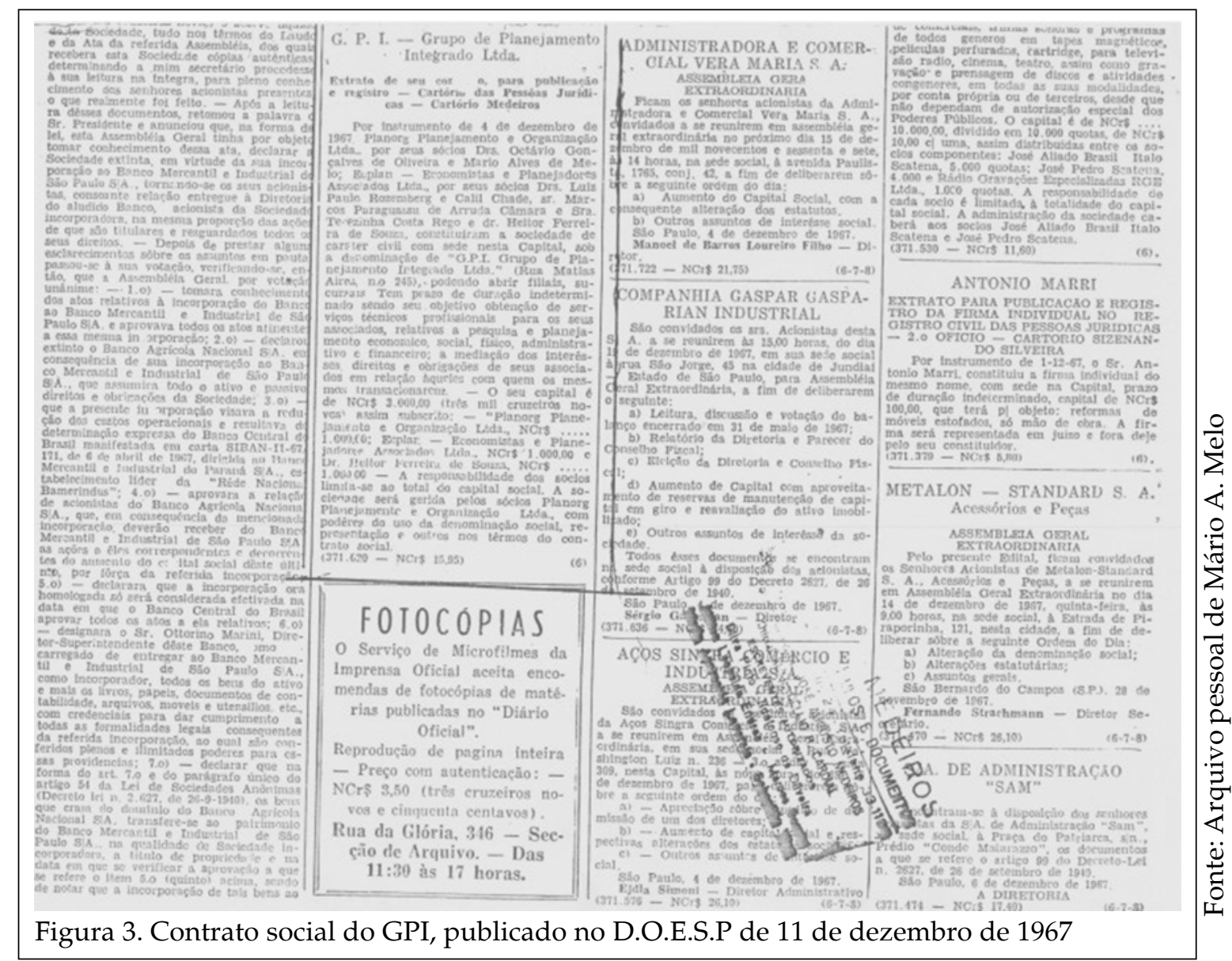

Segundo o testemunho de Aumond,

"a Pólo fazia o trabalho físico-territorial. A ECPlan fazia os trabalhos de demografia e os estudos econômicos sociais. E a Planorg fazia os estudos de natureza institucional. Mas essas três empresas sozinhas, era muito complicado administrar isso, e ali entra o papel do Sérgio, que dizia vamos unificar isso aqui sobre uma empresa só, chamada GPI-Grupo de Planejamento Integrado Ltda, nisso se incorporaram as três, mas nessa área dos estudos institucionais, o Mário Melo ficou responsável. Aqui na área de estudos físico-territoriais e urbanísticos ficava o Heitor e na área da ECPlan ficava o Diógenes. Constituíram uma empresa.

Os sócios eram as pessoas das empresas e aqui você tinha como diretor superintendente, quem armou essa unificação, foi o Sérgio Vieira da Mota. Porquê o Sérgio? Porque ele tinha uma face legal ampla, era um homem de esquerda ligado à Ação Popular de SP, aliás, o dirigente, e isso formava uma grande frente. E que sabia conviver com as suas diferenças e essas frentes tinham duas coisas: um trabalho técnico e o GPI não desenvolvia nenhum trabalho político, o problema do GPI era o trabalho técnico. As pessoas de dentro tinham as suas opções políticas e não podiam envolver o GPI, e essa face aberta era Sérgio.

Eu de início trabalhei diretamente com o Diógenes nessa constituição de diretoria, como superintendente. O diretor técnico do GPI era o 
Diógenes, quando o Diógenes foi preso, em 70. Ele da prisão mandou um recado dizendo: Walter, eu quero que você assuma a direção técnica. Então eu assumi junto com o Sérgio a direção técnica e por volta de 1971, neste momento o Sérgio resolveu sair do GPI e criou a Sociplan , que era dele, que veio a se tornar a Hidrobrasileira"12.

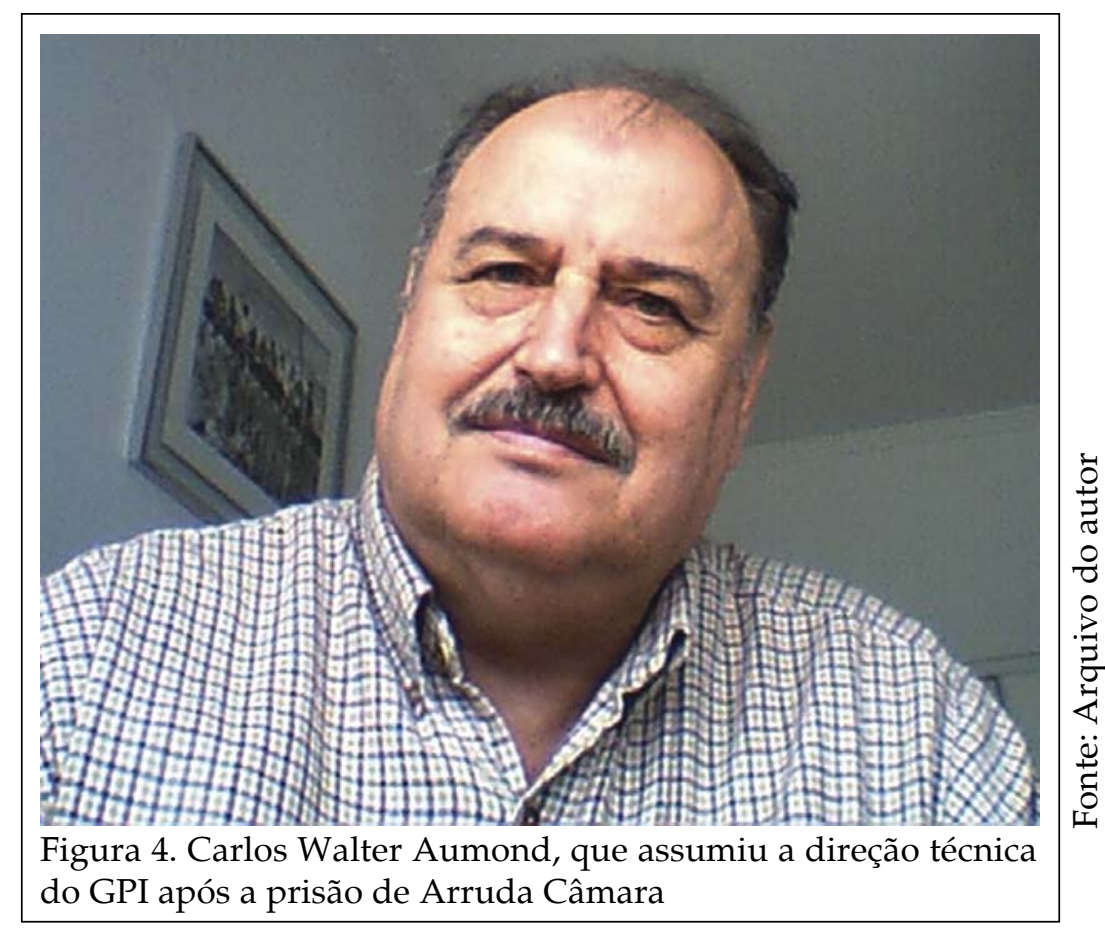

Criada, portanto, com a junção dos esforços e dos interesses das empresas e de suas equipes técnicas (constituindo uma espécie de consórcio, pois todas as empresas funcionavam no mesmo local), inicialmente os sócios indicaram o engenheiro Sérgio Vieira da Motta para diretor-superintendente do GPI, com a função de coordenar os trabalhos. Bastante ligado ao movimento estudantil de esquerda na época, liderança da Ação Popular - AP (movimento da esquerda católica), Motta posteriormente viria a ser um dos principais dirigentes do Partido da Social Democracia Brasileira - PSDB e ministro do governo de Fernando Henrique Cardoso (1995-2002) ${ }^{13}$.

Carlos Walter Aumond ${ }^{14}$, que sucedeu Motta como coordenador técnico do GPI, coloca inclusive a participação de Câmara e de Motta nas empresas como fundamentais para seu retorno do exterior, onde se encontrava quando ocorreu o golpe, afirmando que foram eles que sustentaram sua vinda. Segundo Aumond, quem o contratou, de uma maneira que ficasse numa atividade que não tivesse grande exposição, com um local fixo de trabalho, foram Sérgio Vieira da Motta e Diógenes de Arruda Câmara.

\footnotetext{
${ }^{12}$ Informações obtidas em entrevista ao autor, realizada em 23/07/2004, São Paulo-SP.

${ }^{13}$ Segundo PRATA (1999:62) "os caminhos que levariam Sérgio Motta a Fernando Henrique, amizade que a política consolidou, começaram por outras circunstâncias. Quem aproximou os dois, por volta de 1970, foi o sociólogo Chico de Oliveira, que por sua vez conhecera Motta na empresa de planejamento GPI - Grupo de Planejamento Integrado Ltda., via outro militante de esquerda, Diógenes de Arruda Câmara".

${ }^{14}$ Informações obtidas em entrevista fornecida por Carlos Walter Aumond ao autor em 23/07/2004, São Paulo-SP.
} 
Ainda segundo Aumond, era possível, nestas condições, exercer atividades profissionais na legalidade, pois a estrutura da repressão política governamental ainda não estava suficientemente azeitada para agir em todos os setores, os organismos de repressão política não possuíam ainda integração e logística suficientes para desbaratar os agrupamentos opositores. Com isso, empresas como o GPI funcionavam regularmente, firmando contratos e executando serviços para organismos públicos como o SERFHAU e prefeituras municipais, utilizando nos trabalhos técnicos com alta reputação e qualificação, embora contrários ao regime.

Apesar de ter entre seus proprietários alguns notórios comunistas e opositores do regime militar, até o final de 1968 o GPI não foi muito incomodado pela repressão naqueles anos, pois não havia ainda uma política de segurança estruturada e articulada o suficiente para impor maiores restrições à sua atuação.

Foi somente após a edição do Ato Institucional n n. 5, em dezembro de 1968, que a repressão aos opositores do regime se intensificou de forma violenta, levando à prisão e à tortura comunistas mais conhecidos como Diógenes de Arruda Câmara ${ }^{15}$, à cassação de intelectuais, professores universitários e ativistas políticos de esquerda, precipitando setores mais radicais da esquerda na resistência armada ao regime militar. Nesse momento, a estrutura de repressão foi montada de maneira mais profissional e eficiente, articulada de fato a partir da denominada Operação Bandeirante (OBAN), organizada de forma clandestina, o que evitaria qualquer constrangimento legal ao governo, que obviamente negava envolvimento com ações criminosas e ilegais, embora naturalmente coordenasse a iniciativa, que contava com apoio direto de empresários. Então, havia uma profusão de siglas que designavam os diversos órgãos de informação (espionagem interna) e repressão: Serviço Nacional de Informações (SNI), criado em 1964, objetivando ser uma assessoria de espionagem do governo; Centro de Informações da Marinha (CENIMAR), mais antigo, modelo para outros centros, como o Centro de Informações do Exército (CIEX) e o Centro de Informações da Aeronáutica (CISA), criados respectivamente em 1967 e 1968 . Tais órgãos, que atuavam de maneira independente e pulverizada em cada uma das corporações militares da qual faziam parte, eram visivelmente ineficazes no combate à guerrilha urbana que se iniciava, o que lhes retirava parte da liberdade de ação. Foi somente a partir de julho de 1969, na capital de São Paulo, onde a guerrilha urbana possuía uma ação mais atuante e evidente, que os órgãos de repressão organizaram a Operação Bandeirante (OBAN), na tentativa de centralizar e coordenar as operações anti-guerrilha, para debelar a oposição armada. A tuan d o de forma clandestina, não oficial, a OBAN podia realizar ações violentas, sem responder a qualquer cobrança do judiciário ou de respeito à legislação, mesmo de exceção, nem se preocupar com a eliminação por tortura ou assassinato dos opositores ao regime. A OBAN recrutava membros das polícias estaduais (civil e militar), das Forças Armadas e até mesmo entre civis, ligados sobretudo a grupos radicais de direita paramilitares, como o Comando de Caça aos Comunistas - CCC, composto por civis, policiais e militares. Além disso, para não depender exclusivamente de verbas públicas, a OBAN

${ }^{15}$ Diógenes ficou preso de 11 de novembro de 1969 a 22 de março de 1972, como relatou em entrevista a Iza Freaza (BERTOLINO, 2004). 
recolhia dinheiro de muitos empresários ligados à extrema direita política, com o pretexto do combate à subversão. (NAPOLITANO, 1998)

A partir da plena estruturação e funcionamento da OBAN, a prática do seqüestro e da tortura (muitas vezes em locais clandestinos) de suspeitos tornou-se sistemática e metódica, uma verdadeira política de Estado, acima da lei. Para os militares, justificavase a prática da tortura nos suspeitos como sendo necessária para extrair informações rápidas do preso, que levassem ao desmonte de grupos clandestinos de oposição. $\mathrm{Na}$ verdade, além de injustificável de qualquer ponto de vista humano, essa prática seria desnecessária enquanto técnica de obtenção de informações. Na verdade, esse era o seu objetivo secundário. Através de infiltração de agentes, delação espontânea de muitos ex-guerrilheiros, interrogatórios sem uso de violência física, cruzamentos de informações e outros meios de caráter de inteligência policial, seria perfeitamente possível vencer qualquer tipo de guerra, mesmo uma guerrilha urbana forte e organizada, o que nem era o caso. Na verdade,

\begin{abstract}
"ao montar um aparato de vigilância e repressão baseado na tortura, alguns setores ligados ao regime militar queriam de fato atingir outro objetivo: a destruição física e psicológica do militante de oposição, impedindo não só sua recomposição como pessoa humana, mas também a própria recomposição da organização à qual ele pertencia. A tortura era a materialização do "círculo do medo". Nesse sentido, sim, ela foi eficaz." (NAPOLITANO,1998:36)
\end{abstract}

Apesar de toda a repressão política que se instalou no período, dos sobressaltos e do medo, apesar de todas as dificuldades e vicissitudes de viver sob uma ditadura militar, com Sérgio Motta à frente e, a partir de 1970, com a saída de Motta para tocar seus próprios negócios (primeiro criou uma empresa de planejamento, a SOCIPLAN, depois a de consultoria e engenharia de projetos, chamada HIDROBRASILEIRA), sob a coordenação de Carlos Walter Aumond, o GPI obteve importantes contratos para a elaboração dos trabalhos de Planos Diretores de Desenvolvimento Integrado de dezenas de cidades além de Franca, como Mogi-Guaçu (1967-1968), Votuporanga (SP) 19691970, Maceió (AL) 1969-1971, Ourinhos (SP) 1971, Diadema (SP) 1971, Taubaté (SP) 1972, Barra Mansa (RJ) 1972, Resende (RJ) 1972, assim como de outros estudos de viabilidade técnica, como do Distrito Industrial de Santos (SP) e de aspectos do Plano Urbanístico Básico - PUB, da capital de São Paulo, na sua maioria financiados com recursos públicos provenientes do SERFHAU ${ }^{16}$.

Tal volume de trabalho somente foi possível porque a regulamentação da atuação do SERFHAU, a partir de 1966, forneceu condições para o financiamento aos municípios que optassem por contratar a elaboração de planos de desenvolvimento local integrados, introduzindo a possibilidade de expansão das empresas de engenharia e consultoria do país e sua entrada no setor de desenvolvimento urbano (FELDMAN, 2005b). A maioria dos Planos Diretores, porém, vai ser elaborada após 1967 por estas empresas especializadas, criadas majoritariamente após a regulamentação do SERFHAU, tornando

\footnotetext{
${ }^{16}$ Todos os Planos citados possuem cópia depositada na biblioteca da FAUUSP.
} 
clara a importância deste organismo para a elaboração dos planos diretores municipal naquele período, e para a institucionalização de processos de planejamento nos municípios através da criação de um órgão municipal responsável pelo setor, cuja existência e estruturação era indispensável para a autorização dos financiamentos dos planos. (FELDMAN, 2005a apud AZEVEDO, 1976)

Maurício Cadaval, um dos técnicos da empresa e que foi um dos coordenadores do Plano de Franca, afirma que "o GPI se valeu dos contatos do PCB no Estado de São Paulo e no Governo Federal (junto ao antigo SERFHAU) para obter contratos. Um deles foi com a Prefeitura de Franca para a elaboração do Plano de Desenvolvimento Integrado, por volta de $1968^{\prime \prime}{ }^{17}$. Foi impossível estabelecer e comprovar a existência desta conexão, nem sequer como foi realizado o contrato entre o GPI e a Prefeitura de Franca ${ }^{18}$.

Segundo Heitor, de posse do cadastro do GPI no SERFHAU, eram ele e Mario Melo que procuravam pessoalmente os prefeitos das cidades que tinham condições de obter o financiamento para elaborar o Plano e tentavam articular a contratação direta, a partir dos conhecimentos e informações que dispunham sobre a disponibilidade de recursos no SERFHAU e a forma de obtê-los para o município interessado.

O fato é que a empresa tornou-se realmente uma referência para abrigar oposicionistas ao regime militar: além dos próprios Diógenes Arruda Câmara, Sérgio Motta, Carlos Walter Aumond e Heitor Ferreira de Souza, podem ser citados o arquiteto Jairo José Farias, responsável pela elaboração do projeto físico da proposta do Distrito Industrial de Franca, que estava na primeira lista de cassados pelo novo regime, ainda em 1964, pelo Ato Institucional n . 1, de 10 de abril, juntamente com João Goulart, Miguel Arraes, Leonel Brizola e tantas outras lideranças consideradas à esquerda no espectro político da época; o arquiteto João Batista Vilanova Artigas, cassado e aposentado compulsoriamente da FAU USP em 1969, era freqüentador assíduo da sede do GPI, para discutir ações políticas e também, ao que parece, desenvolvendo trabalhos no município de Itu; o economista e professor da USP Norberto Nehring, pertencente aos quadros do PCB, foi preso político e provavelmente assassinado sob tortura pela repressão governamental.

A biografia de Nehring, elaborada por sua mulher, a socióloga Maria Lygia Quartim de Morais, mostra o envolvimento de um destes militantes políticos, vinculado à ALN, com o GPI:

"Fazíamos parte dos entusiastas das reformas de base, da modernização democrática. Éramos uma geração altamente politizada. Tínhamos ingressado no PCB assim que entramos na faculdade (...) Norberto militou no PCB até a ruptura do grupo Marighella - passou então a fazer parte do grupo que trabalhava diretamente com Joaquim Câmara Ferreira, "Toledo" ou "Velho", na coordenação da ALN em São Paulo (...) uma vez formado na USP (o paraninfo de sua turma, em 1967, foi Caio Prado Júnior) começou imediatamente a trabalhar em

\footnotetext{
17 Informações obtidas em entrevista por e-mail, em 19 de dezembro de 2005, 10h34min h, mauroferreira52@yahoo.com.br.

${ }^{18} \mathrm{O}$ contrato entre GPI e Prefeitura de Franca não foi localizado no arquivo do Município, provavelmente foi incinerado, nem nos arquivos da Caixa Econômica Federal, que guarda os documentos do SERFHAU.
} 
planejamento econômico, no Grupo de Planejamento Integrado - GPI, um dos primeiros do gênero, formado por economistas e arquitetos competentes. Norberto trabalhava com Arruda Câmara, Sérgio Motta, Sérgio Ferro, entre outros ${ }^{19}(\ldots)$

Norberto era economista, foi instrutor da disciplina de História Econômica da Faculdade de Economia da USP em 1967, cuja catedrática era a professora Alice Canabrava. Em 1968, passou a cursar a pós-graduação em Economia no Instituto de Pesquisas Econômicas da USP. Mas, ao mesmo tempo que trabalhava e estudava,

sua militância na ALN intensificava-se. Integrava o grupo da "casa de armas", dado seus conhecimentos de química e a enorme confiança pessoal que nele depositava a coordenação da organização (...) Norberto passou a ser o elemento de ligação com um grupo da ALN da cidade de Marília (...) na manhã do dia 7 de janeiro de 1969 uma cena insólita perturbou a tranqüilidade da vila em que morávamos: nossa casa foi cercada por um grupo de policiais do DOPS, que levaram Norberto preso. Logo que foi solto, após mais de dez dias na carceragem do DOPS, Norberto "passou para a clandestinidade", sabendo que voltaria a ser preso e torturado como aconteceu com todos os acusados do mesmo processo. Muitos dos acusados estavam sendo brutalmente torturados e houve uma tentativa de suicídio numa tarde em que fui visitá-lo ${ }^{19}$.

A partir da prisão, Norberto certamente percebeu que não haveria mais possibilidade de sobreviver no país e que sua segurança seria cada vez mais precária, decidindo-se pelo exílio.

Em abril de 1969, Norberto saiu do país com destino a Cuba... Ele retornou ao Brasil em abril de 1970, depois de uma estada em Praga, desembarcando no aeroporto do Galeão. As circunstâncias exatas de sua morte nunca puderam ser estabelecidas. Ficamos sabendo da morte de Norberto através de mensagem, segundo a qual, no dia 24 de abril um caixão teria saído da OBAN carregando Norberto, morto na tortura, nas mãos da equipe do delegado Fleury (...) Seu comportamento na prisão sempre foi exemplar: nunca revelou qualquer fato ou nome que comprometesse ou prejudicasse terceiros. Acreditava no socialismo e deu sua vida por aquilo que considerava ser o caminho da libertação do povo brasileiro"19.

${ }^{19}$ Trechos da biografia de Norberto Nehring, publicada no Dossiê dos Mortos e Desaparecidos Políticos a partir de 1964, (DOSSIÊ DOS MORTOS E DESAPARECIDOS POLÍTICOS, 1996: 90). 


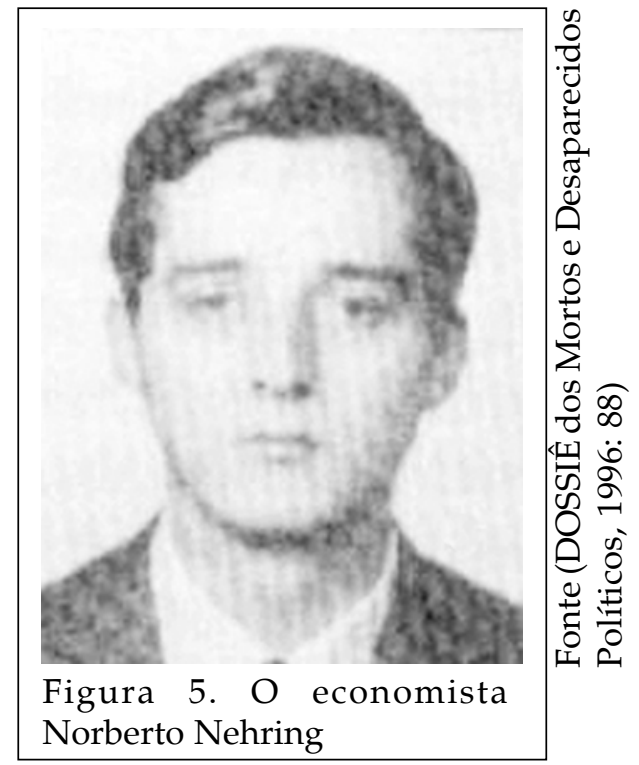

Saliente-se ainda que a Ação Popular - AP, organismo ao qual os dois militantes políticos que assumiram a superintendência do GPI, Carlos Walter Aumond e Sérgio Motta, estavam ligados, surgiu a partir do pontificado de João XXIII. A Juventude Universitária Católica, a JUC, era por demais vinculada à hierarquia da Igreja, motivo pelo qual a criação de um outro veículo de ação política como a AP poderia permitir uma liberdade de atuação que não envolveria a hierarquia católica. Em 1963, a AP aprovou documentos explicitando sua opção pelo socialismo, já institucionalizada como uma corrente poderosa dentro do movimento estudantil, que posteriormente a levaria a apoiar a luta armada. (GORENDER, 1987)

Diógenes de Arruda Câmara ${ }^{20}$ era importante dirigente do PCB desde os anos 30, até cair em desgraça junto a Luiz Carlos Prestes quando ocorreu a divulgação dos crimes do stalinismo, e acabou perdendo seus cargos no Comitê Central do Partido Comunista Brasileiro, tornando-se militante do Partido Comunista do Brasil - PC do B a partir de 1966, pouco tempo após a dissidência interna entre os comunistas, já que havia sido criado a partir de 1962. Como o PC do B se afastou completamente da luta armada urbana, preparando-se para a guerrilha rural, o partido foi poupado no início pelos órgãos de repressão. Porém, quando a OBAN se consolidou, a exemplo de Nehring, Diógenes terminou sendo preso e torturado, no final de 1969, quando ainda estava no GPI.

Já o arquiteto Heitor Ferreira de Souza era simpatizante do PCB desde os tempos de estudante da FAUUSP, quando foi aluno de Vilanova Artigas, tornando-se depois um militante do partido, embora nunca tenha ficado na clandestinidade, optando pela atividade empresarial que lhe dava visibilidade e respeitabilidade junto aos governantes. Por isso, de certa forma, pode-se explicar porque desde a criação do GPI havia essa estreita proximidade com os comunistas e a oposição ao regime militar. É o próprio Heitor quem descreve:

${ }^{20}$ Segundo GORENDER (1987: 164), Arruda foi até homenageado com a dedicatória do escritor Jorge Amado, sob o codinome Vítor, no livro “Os subterrâneos da Liberdade”, obra que retrata a vida de Luiz Carlos Prestes sob o prisma do chamado realismo socialista. 
"em Santos foi o trabalho mais consistente profissionalmente, tecnicamente, foi aí que eu conheci (Diógenes), o escritório para montar esta equipe toda, que montamos o GPI, eu não tinha dinheiro, eu voltei pro meu apartamento na Rua Augusta, 2425, até hoje está lá, tive que montar o escritório e o pessoal da Última Hora me arranjou um apartamento que era do Samuel Wainer. No largo do Paissandu, do lado do Cine Paissandu, na esquina, tem uma ladeira chama Carneiro, o apartamento estava no nome do Samuel Wainer, a Última Hora ainda existia, eles pagavam o aluguel, era grande e montei o GPI ali, e era ali que aparecia muita gente ligada ao partido, técnicos né, que estavam na pior" $^{21}$.

Constata-se ainda uma intensa presença e participação de Arruda Câmara nas articulações clandestinas que a esquerda fazia para definir sua opção pela luta armada naquele período: "em São Paulo, tínhamos contactos com Diógenes de Arruda, que saiu do Recife após o golpe e trabalhava numa firma de projetos econômicos. Militante do PC do B desde 1966, recebemos por intermédio dele o convite para um encontro com a direção do seu partido." (GORENDER, 1987:101)

Assim, a vinculação de alguns dos seus proprietários e de parcela expressiva do corpo técnico das empresas que compunham o GPI, à oposição ao regime militar é evidenciada na composição da equipe, muitos deles egressos de movimentos ou organizações políticas clandestinas, principalmente comunistas, que se opunham à ditadura, alguns até optando pela luta armada contra o regime. Trata-se, sem dúvida, de uma estratégia de sobrevivência formulada durante aquele período de repressão às liberdades democráticas, estabelecendo uma espécie de rede de apoio que dava guarida e possibilidade de sobrevivência econômica aos perseguidos opositores do regime militar.

Mario Melo, que não tinha vinculações com o PCB, afirma que o "objetivo da criação do GPI e de suas empresas sócias ou subsidiárias não era a ligação com a oposição comunista, o GPI não tinha preconceitos ideológicos e se valeu do grande número de profissionais extremamente competentes marginalizados pelo regime militar" ${ }^{\prime 22}$. De qualquer modo, a simples existência de uma empresa que contratava pela competência sem se preocupar com a vinculação política dos técnicos, possibilitava a sobrevivência dos opositores do regime, através da escolha efetuada pelos dirigentes ligados à oposição ao regime militar.

Para todos os técnicos e dirigentes participantes do GPI entrevistados, a empresa tinha grande competência e capacidade técnica naquilo que fazia, pois trabalhava com profissionais reconhecidos e de grande competência ou experiência, como os já citados arquitetos João Batista Vilanova Artigas, Heitor Ferreira de Souza e Jairo José Farias, acrescentando-se o geógrafo Aziz Ab'Saber, os economistas Paul Singer, Waldomiro Pecht, Roberto Perosa e Luciano Coutinho (este ainda como estagiário), os arquitetos Jorge Wilheim, Sérgio Zarattin, Sérgio Souza Lima, Carlos Eduardo Zahn, Clóvis Leite Monteiro e Newton Corradini, as técnicas da área social e de saúde Rosa Bromberg e Nobuko

\footnotetext{
${ }^{21}$ Informações obtidas em entrevista fornecida ao autor e Sarah Feldman, 11/11/2004, Rio de Janeiro - RJ.

${ }^{22}$ Informações obtidas em entrevista de Mario Alves Melo ao autor, em 12/03/2007.
} 
Higasi, os administradores públicos Mario Alves de Melo e Otávio Gonçalves de Oliveira, o sociólogo Maurício Cadaval, os técnicos em administração pública, tributação e demografia José Rafael Camelo, Marco Aurélio Queiroz Cahony e Alcides Ribeiro Soares.

Observa-se também que, nos primeiros Planos Diretores elaborados pelo GPI, até 1971, inclusive no Plano Diretor de Desenvolvimento Integrado de Franca, não há indicação da equipe técnica da empresa nos documentos publicados, à exceção do próprio Heitor Ferreira de Souza e Aziz Ab'Saber, apesar das normas estabelecidas pelo FIPLAN, onde deveria constar a equipe técnica autora dos trabalhos.

Pode-se imaginar que, antes de qualquer coisa e nas difíceis circunstâncias do período, esta seria uma forma de proteger e preservar a identidade dos técnicos, pois como vimos, parcela expressiva da equipe estava vinculada a organizações ou movimentos de esquerda contrários ao regime, alguns vivendo numa total ou semiclandestinidade. A identificação da equipe técnica dos trabalhos somente vai ocorrer a partir dos Planos de 1971 em diante, quando Arruda já estava preso e a guerrilha urbana está praticamente desmantelada pela repressão.

A empresa, como tantas outras empresas de planejamento e consultoria criadas no período, durante o chamado "milagre brasileiro" (1967-1973), quando o país tinha um crescimento da ordem de $10 \%$ do PIB/ano, ocupava um espaço necessário ao projeto de desenvolvimento do país imaginado pelo regime militar, e sua competência técnica era inegável.

Os grandes investimentos em obras de infra-estrutura, modernização e industrialização levavam as cidades brasileiras a um processo de rápido crescimento e expansão, que traziam no seu bojo graves questões sociais e espaciais, para as quais não estavam preparadas, e um dos aspectos principais para sua solução, apontada pelo governo federal, seria a implantação do planejamento integrado na administração pública, inclusive no âmbito municipal. A mudança de governo, com a saída de Médici da presidência para a entrada de Geisel, a crise do petróleo e do próprio "milagre brasileiro", desembocou também na extinção do SERFHAU em 1975, assim como na interrupção do financiamento do planejamento integrado e dos Planos Diretores. (VIZIOLI, 1998)

Isto levou a empresa à extinção no final da década de 1970, por falta de trabalho. Nesta fase final, Heitor, que já havia se transferido para o Rio de Janeiro e ingressado no corpo técnico do próprio SERFHAU, tentou dar-lhe sobrevida após a saída de Mário Melo da sociedade, mas não obteve êxito e optou por encerrar as atividades do GPI. Heitor continuou vivendo no Rio de Janeiro, onde atua até hoje, mesmo local onde está Jairo Farias. Nesta época, Diógenes havia se exilado na Europa por razões de segurança, logo depois de ser libertado da prisão (Arruda ficou preso de novembro de 1969 a fevereiro de 1972, vindo a falecer em 1979, logo após seu retorno ao Brasil e da anistia política). A segunda esposa de Diógenes, Tereza Costa $\operatorname{Rego}^{23}$, uma artista plástica que teve de assumir funções técnicas na área de paisagismo e desenho no GPI após a prisão do marido, havia

\footnotetext{
${ }^{23}$ A artista plástica Tereza Costa Rego vive atualmente em Olinda, Pernambuco, onde possui ateliê próprioe coordena o Museu do Mamulengo. Foi possível localizá-la utilizando o site do Partido Comunista do Brasil (www.vermelho.org.br), que repassou nosso pedido de informações pela rede www. Por motivos pessoais, ela se negou a fornecer entrevista, alegando seu sofrimento em relembrar os tempos da ditadura militar.
} 
saído do país também por razões de segurança e para voltar a viver com o marido, primeiro na França e posteriormente na Itália. Hoje, vive em Olinda. Aumond é consultor de empresas e vive em São Paulo, onde também reside Mário Melo.

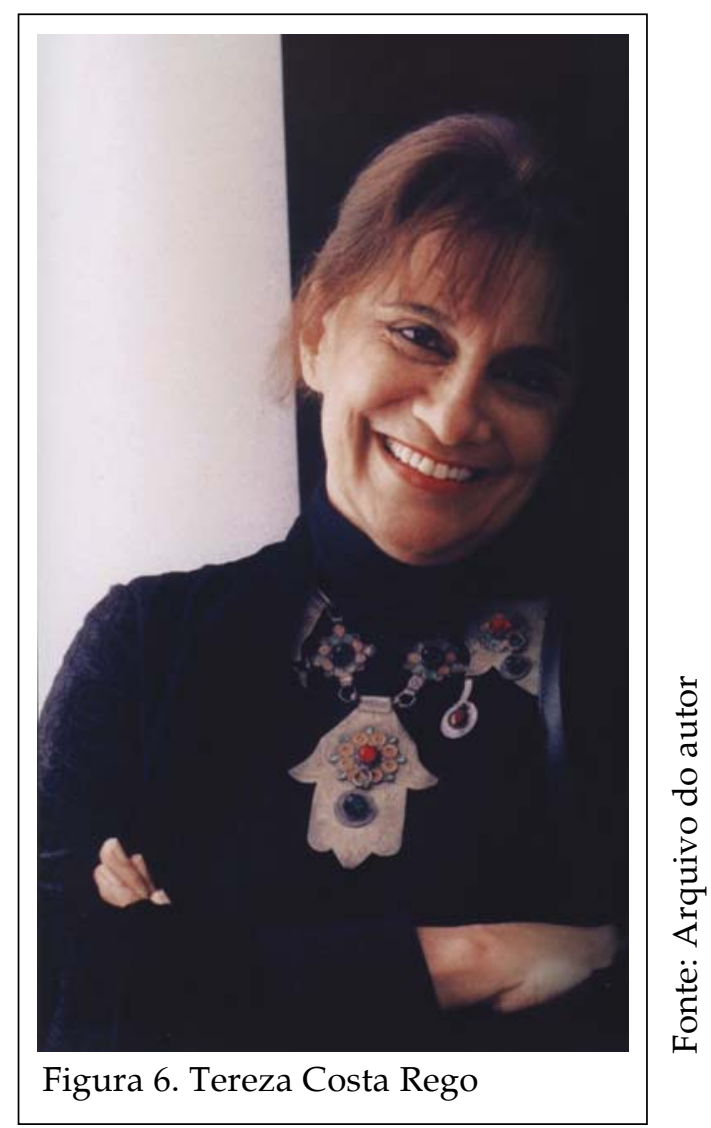

PLANEJAMENTO DURANTE O REGIME MILITAR: CENTRALIZAÇÃO POLÍTICA E O SURGIMENTO DO SERFHAU

O período de elaboração e implementação inicial do Plano Diretor de Franca, no final da década de 1960, já marcado pelo início do governo militar, da centralização política e do autoritarismo, assiste uma vigorosa tentativa de estabelecimento de um novo padrão de planejamento das cidades no Brasil, substituindo definitivamente as idéias que até então ainda subsistiam, mesmo que parcialmente, como aquelas concentradas nas soluções embelezadoras e higienistas, praticados apenas em setores centrais das grandes cidades brasileiras desde o final do século XIX, bem como o urbanismo cujo centro de sua ação se dirige para a modernização do sistema viário em função da introdução do uso do automóvel, focados nas regiões onde viviam e trabalhavam os setores de maior renda e maior poder político da população.

As características fundamentais deste novo padrão de planejamento, que começam a se esboçar a partir dos anos 1930 e ganham força nos anos 1940, são basicamente derivadas de uma concepção desenvolvimentista, especialmente na 
formulação do diagnóstico dos problemas enfrentados pelas cidades. O zoneamento de uso e ocupação do solo, instrumento que preconizava o atendimento das chamadas funções básicas da cidade (habitar, trabalhar, recrear e circular), sozinho, não dá mais conta da complexidade da questão urbana decorrentes da rápida industrialização e urbanização brasileira. Paralelamente, ocorre um processo de institucionalização do serviço de planejamento físico nas municipalidades, fortemente influenciado pela concepção norte-americana, privilegiando soluções técnicas e buscando desvincularse dos conflitos decorrentes de embates políticos e sociais existentes nas cidades. (FELDMAN, 2005a).

Desde os anos 50, o discurso sobre a necessidade do planejamento aparece também como um poderoso antídoto contra os males do subdesenvolvimento e as crises cíclicas do sistema econômico. Tal crença se deveria, em parte,

"ao prestígio alcançado pelas técnicas de planejamento central adotadas pela União Soviética e países da Europa Oriental sob o regime comunista. O planejamento das economias de guerra e os esforços de reconstrução econômica nos anos do pós-guerra contribuíram, por sua vez, para revigorar a crença no planejamento" (CINTRA \& HADDAD: 1978:15).

Ou seja, num contexto de guerra fria e de disputa por hegemonia, entre capitalismo e comunismo, ambos os contendores principais assinalavam a importância do planejamento em suas economias.

No ambiente latino-americano, "o movimento em favor do planejamento teve seu grande impulso principalmente na CEPAL, no Banco Mundial e em várias organizações internacionais, as quais estimulam a proliferação de organizações de nível nacional e subnacional" (CINTRA \& HADDAD: 1978:15), permitindo popularizar a idéia do planejamento tanto à esquerda quanto à direita do espectro político.

Nos anos 1950 e 60, a velocidade do crescimento das cidades brasileiras, sua incapacidade em atender a população com infra-estrutura e condições adequadas de trabalho e moradia e ainda a intensa migração campo-cidade, permitiu a organização de um discurso considerado racional que se torna tradutor dos chamados "problemas urbanos", que transforma as questões sociais em questões técnicas, entendidas como se fossem disfunções do crescimento. A partir deste diagnóstico dito "racionalista", organiza-se um conjunto de medidas e intervenções que se pretende consistente, traduzido na idéia do plano. A conceituação da cidade é ultrapassada pela idéia de "urbano" e de "urbanização", onde se pensam os "problemas urbanos" em uma escala regional ou nacional. O planejamento seria o instrumento para enfrentar os problemas urbanos, sendo então formulados os conceitos de rede urbana, hierarquias urbanas, sistemas de cidades, principalmente a partir de discussões no âmbito do governo central. Durante o regime militar, a elaboração dos Planos Nacionais de Desenvolvimento PND e suas estratégias para disciplinar a ocupação urbana e rural do território nacional envolvem a descentralização das atividades produtivas e de dinamização das chamadas funções urbanas, principalmente de apoio à agroindústria e à agropecuária. (RIBEIRO e CARDOSO, 1990) 
De outro lado, por esta interpretação, ganharia força entre os novos governantes do país a idéia que a intervenção passe a ter como objeto o próprio poder, na medida em que se apresentam as causas dos "problemas urbanos" como sendo os entraves políticos do período anterior, entre 1946 e 1964, por eles chamado de "populista" na gestão pública da cidade, que a tornavam ineficiente para superar as patentes insuficiências do desenvolvimento econômico. Portanto, sob esta ótica, a modernização induzida e a centralização política cumpriria um papel de ordenadores e racionalizadores da ação do poder público sobre as cidades, principalmente do poder local, incorporando as propostas advindas do planning americano que vinham sendo discutidas principalmente desde os anos 1930, assumindo o urbano como um problema do desenvolvimento econômico, buscando gerir a cidade existente com eficiência. Este padrão iria produzir uma "tecnificação" e "despolitização" dos problemas urbanos, num processo de transformação tecnocrática da questão social. As políticas com impacto direto sobre a produção das cidades são centralizadas e concebe-se a idéia de um abrangente e vasto sistema nacional de planejamento. Estas concepções gerais, embora estivessem sendo gestadas desde os anos 1930, e apesar de existirem contradições internas sobre os rumos a tomar, são amplificadas e exacerbadas pela tecnoburocracia emergente, a partir do regime militar e passam a conduzir as ações dos novos organismos federais ligados à questão urbana, especialmente do Banco Nacional de Habitação - BNH e do Serviço Federal de Habitação e Urbanismo - SERFHAU, criados em 1964. Ao SERFHAU caberia o papel de promover, difundir e uniformizar a prática de elaboração de planos diretores de desenvolvimento, segundo uma postura de integração multidisciplinar, numa perspectiva de racionalidade técnica. Nesta concepção, a idéia de neutralidade da atuação governamental é enfatizada. É valorizado o saber competente, o saber técnico, na elaboração das propostas de intervenção nas cidades. Com isso, imaginava-se minimizar os conflitos políticos, o que ocasionaria a continuidade de exclusão dos segmentos populares do processo de planejamento do espaço das cidades. (RIBEIRO e CARDOSO, 1994)

Porém, a criação do SERFHAU, ao mesmo tempo em que representou um passo decisivo para a consolidação do planejamento como função de governo, legitimando esta idéia e respondendo ao princípio da hierarquização e da tecnicização das funções de planejamento, também estabeleceu estímulos à elaboração de planos diretores de desenvolvimento local integrado, principalmente através de linhas específicas de financiamento aos municípios. (FELDMAN, 2005a)

Esta política significa também a implementação de medidas de controle e tutela da esfera de poder municipal, dado o caráter centralizador do regime militar, utilizando legislações estaduais, como a Lei Orgânica dos Municípios paulistas de 1967, que condicionava o repasse de recursos ou empréstimos à existência do Plano Diretor, embora tal imposição não tenha efetivamente se concretizado. Este conjunto de medidas adotadas pelas políticas desenvolvidas durante o regime militar, que se traduzia em ações como o próprio financiamento dos planos, neles incluindo uma reforma administrativa, partiam do pressuposto que a introdução do processo de planejamento nas Prefeituras, sendo indutor do aprimoramento e modernização da Administração Municipal e de sua eficiência, em conseqüência, traria melhoria das condições de vida da comunidade local. (AZEVEDO, 1976) 
Contudo, não se pode pensar a ação exercida pelo SERFHAU sem antes verificar que o poder local já vinha sendo objeto de amplo debate sobre suas funções e como já se estava tratando da questão do seu planejamento desde os anos 1920, até mesmo porque a ideologia municipalista sempre se constituiu uma das construções discursivoprogramáticas mais antigas na cultura política brasileira. (MELO, 1993)

Ao final do Estado Novo, diversas instituições do Estado, influenciadas pela experiência norte-americana, como o DASP e o IBGE, constituíam-se numa espécie de elite administrativa, uma burocracia técnica que buscava modernizar a ação estatal, posicionando-se e mobilizando intensa campanha em torno do municipalismo, visto como local privilegiado para implementar a modernização do país. A constituição da Associação Brasileira dos Municípios - ABM, durante o processo Constituinte de 1946, possibilitava a inclusão no debate do funcionamento do setor público e metodologias de trabalho no serviço público e a disseminação de novas técnicas de administração municipal. (MELO, 1993)

A criação do Instituto Brasileiro de Administração Municipal - IBAM, a partir de proposta apresentada no Congresso Brasileiro de Municípios em 1952 e no âmbito de programa de cooperação técnica com o Usaid - United States Agency for International Development, cria as condições para a difusão das técnicas que possibilitariam uma ampla reformulação administrativa dos municípios.

\begin{abstract}
"O objetivo do municipalismo é pragmático: a reforma administrativa municipal. Essa reforma compreenderia objetivos múltiplos e abrangentes, a serem perseguidos através de atividades de assistência técnica: ampliação das bases fiscais dos municípios; elaboração de cadastros fiscais; instituição do sistema de mérito na política de pessoal; criação de planos de cargos e salários; racionalização administrativa; organização e métodos na administração municipal; implementação de modernos procedimentos e técnicas de elaboração e controle orçamentário e de prestação de contas; e racionalização da provisão dos serviços urbanos." (MELO: 1993:95)
\end{abstract}

O IBAM, localizado no Rio de Janeiro e consolidado na década de 50, envolveuse em diversas atividades de consultoria aos municípios brasileiros, difundindo técnicas e métodos de administração pública focalizadas na elaboração e controle orçamentário e na utilização de bases estatísticas, construindo um campo disciplinar que inclui a gestão urbana, ou seja, inaugurando uma forma de organizar o município e as suas instituições públicas que se traduzia numa nova cultura organizacional, cuja influência sobre a constituição e métodos do SERFHAU não é nem um pouco desprezível. (MELO:1993)

Decorrência direta das idéias que geraram o SERFHAU, também os governos estaduais procuraram avançar no tratamento desta questão e criar novos instrumentos para a preparação de quadros permanentes nas administrações públicas municipais e da qualificação do planejamento municipal, através da criação, em 1967, do Centro de Estudos e Pesquisas de Administração Municipal - CEPAM, órgão vinculado à Secretaria de Estado dos Negócios do Interior do Estado de São Paulo, transformada 
posteriormente em Fundação Prefeito Faria Lima, bem como da Fundação João Pinheiro em 1969, órgão vinculado à Secretaria de Estado do Planejamento de Minas Gerais. No caso do CEPAM, uma de suas principais tarefas, desde sua criação, foi a preparação de administradores municipais, através de cursos ministrados por seus técnicos. Esta tarefa estava relacionada a uma visão que considerava que a viabilização do processo de planejamento somente seria possível com a formação de uma equipe de trabalho que tivesse se constituído no bojo do próprio processo de planejamento, pois apenas esta equipe local teria condições de promover sua constante adaptação às circunstâncias sociais, culturais, econômicas e políticas do município onde atuavam. (AMBROSIS, 1972)

No caso específico do planejamento urbano, embora as idéias e metodologias que nortearam a elaboração dos Planos Diretores tenham sido bastante disseminadas no período de atuação do SERFHAU, que teve importante participação do IBAM e de diferentes setores envolvidos na defesa do planejamento urbano em sua formulação, como as entidades profissionais dos arquitetos e tenham concorrido decisivamente para moldar uma imagem de identidade com o período militar por seu forte viés tecnocrático e autoritário, há farta literatura disponível para demonstrar que elas estavam sendo realmente elaboradas e gestadas desde as décadas de 1920 e 1930. (FELDMAN, 2005a)

Os principais defensores do planejamento e de sua institucionalização enquanto processo, de estruturação dentro e fora do setor público, como o paulistano Anhaia Mello, são responsáveis pela difusão do ideário norte-americano (city planning) e pela constituição de um corpo técnico de urbanismo na administração pública, tendo como pano de fundo a modernização do Estado na era Vargas, o crescimento das cidades e a industrialização, que criam novos conflitos espaciais, como o surgimento de prédios verticalizados, de grandes plantas industriais e comerciais, de novas necessidades de transporte de massa, que proporcionam um intenso debate sobre novas formas de regulação e controle do espaço urbano. O esforço de modernização do Estado propicia a introdução de novas concepções de administração pública que vai se referenciar na teoria americana, substituindo a influência francesa até então predominante, trazendo no seu bojo a "scientific management school" e o taylorismo, a eficiência racionalista adotada pelas empresas privadas. Ou seja, as teorias administrativas do setor público brasileiro se desenvolvem, desde os anos de 1930, predominantemente sobre o referencial americano e exercem grande influência sobre outras instituições, como na Escola Politécnica da Universidade de São Paulo, onde Anhaia Mello, seu maior defensor na esfera do urbanismo desde a década de 1920, se formou (1913) e lecionou (1918 a 1968). Seu papel de liderança na defesa das idéias americanas, de desvinculação entre as esferas técnica e política do urbanismo, e o longo tempo de atuação na universidade, formadora de quadros técnicos para o exercício de funções públicas importantes assumem papel importante no desenvolvimento e disseminação das idéias que afastam os setores de planejamento e urbanismo da rotina da administração municipal, bem como da ênfase nas soluções técnicas. Ou seja, os aspectos fundantes destas teorias privilegiam as soluções técnicas, procurando desvincular a administração técnica dos conflitos do cotidiano, moldando estruturas organizadas de forma hierárquica e sob a responsabilidade de um executivo forte. O planejamento passa a ser entendido como uma função de governo. A programação do trabalho, indispensável à administração pública, como uma técnica de trabalho, pressupõe a implantação de um processo coordenado, de rotinas e métodos. Com isso, a criação de órgãos de planejamento constitui-se em aspecto 
importante para consolidar a idéia do papel central dos mesmos nos governos, como coordenadores executivos, capazes de obter uma visão compreensiva dos problemas urbanos e do futuro da cidade. (FELDMAN, 2005a)

A complexidade que a vida moderna assumia seria um outro dos componentes essenciais de convencimento dos governantes, que exigiria o emprego do planejamento governamental em grande escala, entendendo este processo como o instrumento de ação que permitiria uma intervenção considerada racional e ordenada do Estado, tanto no domínio econômico quanto na organização das cidades, que permitisse o desenvolvimento de suas potencialidades. (MODESTO, 1968)

A transição para uma economia de predominância industrial é apontada também como um dos fatores principais para que o Estado brasileiro passasse a adotar, de forma cada vez mais progressiva e abrangente, técnicas de planejamento governamental. $\mathrm{O}$ planejamento tinha como destino a transformação, ou de outra forma, a capacidade de consolidar as estruturas econômicas e sociais do país, que transparece na criação de estruturas político-administrativas especiais, que hipertrofiam o Executivo. Por isso, "o processo de planejamento implica na formação de grupos sociais novos, como os tecnocratas, por exemplo, que podem assumir posições especiais, favorecendo mais ou menos diretamente os interesses econômicos e políticos de certas classes sociais" (IANNI, 1971:87). A idéia de planejamento passou a ser adotada por todos os governantes, como uma nova retórica política, ladeada pela composição dos quadros administrativos do Estado de técnicos, especialistas, profissionais, com base num tipo de pensamento "técnico" ou "racionalista". Há uma nova estrutura de poder: "a tecnoestrutura estatal. Trata-se de uma estrutura de poder largamente apoiada em novas organizações burocráticas, dispondo dos recursos específicos de um certo tipo de pensamento técnico-científico" (IANNI, 1971:98).

Esta nova estrutura dispõe, portanto, de novas ferramentas organizacionais e institucionais que permitem elaborar uma compreensão mais ampla da realidade, focalizando problemas de curto, médio e longo prazo, que podem divergir das razões do Legislativo, permeando todas as instâncias decisórias do Executivo, debaixo de uma pretensa capa de "neutralidade e racionalidade", embora fosse, sob todos os aspectos, inexistente. (IANNI, 1971)

Ressalte-se também que no início do regime militar (1964-1985), havia uma preocupação de governo com ações planejadas e estratégicas de longo prazo, assim como uma acentuada iniciativa no sentido de organizar de forma hierárquica e precisa a estrutura governamental. Porém, vários estudos apontam que essa preocupação com o planejamento não é uma invenção do regime autoritário, ela estava presente também durante o interregno democrático entre a ditadura do Estado Novo e o período do regime militar. (IANNI, 1971 e CINTRA e HADDAD, 1978)

Indicativo desta preocupação anterior ao regime militar com o planejamento governamental é que, nos últimos dias do governo de João Goulart, foi promulgada a lei federal $n^{\circ}$. 4.320, de 17 de março de 1964, que estabeleceu a obrigatoriedade da adoção do sistema Orçamento-Programa com base no planejamento, instrumento que vai exigir algum tipo de planejamento financeiro da administração pública. A Lei Complementar n'.3, de 7 de dezembro de 1967, já sob o regime militar, corrobora e mantém a sistemática do Orçamento-programa, deixando claro que a idéia do planejamento dos gastos e 
investimentos públicos estava consolidada na administração pública, independentemente dos componentes políticos envolvidos no orçamento. (IANNI, 1971)

A própria criação de um organismo federal para enfrentar os desafios da crescente urbanização do país já havia surgido durante o governo de Goulart, no "Seminário de Habitação e Reforma Urbana" realizado em Petrópolis (RJ), em 1963, proposta basicamente defendida pelas corporações e entidades profissionais dos arquitetos. $\mathrm{O}$ documento final do Seminário apresenta, dentre outras, a seguinte proposta:

"Que o Poder Executivo envie projeto de lei ao Congresso Nacional corporificando os princípios da Política Urbana e Habitacional e de Reforma Urbana aprovadas neste seminário e contendo os seguintes pontos:

I) Do Órgão Executor da Política Habitacional e Urbana

1) A fim de disciplinar e coordenar todos os esforços necessários à correção da carência habitacional e de seus problemas de aproveitamento do território, o governo deve criar um órgão Central Federal, com autonomia financeira e competência de jurisdição sobre todo o território nacional, incorporando-se a ele a Fundação da Casa Popular e o Conselho Federal de Habitação.

2) Esse órgão deve ter as seguintes atribuições:

a) fixar as diretrizes da política habitacional e de planejamento territorial do país, através da elaboração de planos nacionais, territorial e de habitação, de duração pluri-anual, tomando todas as resoluções que lhe parecerem necessárias para assegurar o seu pleno desenvolvimento, sendo que, na sua execução, sempre que possível, deve ser descentralizada.(...)" (apud SERRAN, 1976:59)

Logo após o golpe militar, evidentemente com outras características políticas que aquelas preconizadas pelo documento de Petrópolis, a mesma lei federal $\mathrm{n}^{\circ}$. 4.380, de 21 de agosto de 1964, que criou o Banco Nacional da Habitação - BNH, também instituiu uma autarquia, o Serviço Federal de Habitação e Urbanismo - SERFHAU, ao qual foram confiados, exatamente como a seus precursores na política habitacional, objetivos de longo alcance, a serem obtidos mediante planejamento. Além dos aspectos ligados especificamente à questão da habitação, estabelecia a nova lei que uma das atribuições do SERFHAU deveria ser a prestação de assistência técnica aos estados e municípios, na elaboração de planos diretores, instituindo normas técnicas para esta elaboração adaptada às peculiaridades regionais. (CINTRA e HADDAD, 1978)

\section{O PAPEL DO SERFHAU NO FINANCIAMENTO E ELABORAÇÃO DOS PLANOS DIRETORES DE DESENVOLVIMENTO INTEGRADO}

No entanto, somente em 1966 o decreto federal $\mathrm{n}^{\circ}$. 59.917, editado em 30 de dezembro, regulamentou as funções específicas do SERFHAU, sendo suas principais tarefas a elaboração e coordenação das políticas nacionais de planejamento local integrado, através do estabelecimento de normas e roteiros para os planejadores, propostas de legislação, assistência técnica e difusão de experiências, dentre outras 
atribuições. Na prática, a assistência técnica aos municípios seria sua principal, senão única, atribuição possível de realizar, tanto que em 1970, são eliminadas suas atribuições coordenadoras das políticas nacionais de planejamento. (FELDMAN, 2005a)

O mesmo decreto que regulamentou o SERFHAU criou ainda o Fundo de Financiamento de Planos de Desenvolvimento Local Integrado - FIPLAN, destinado a prover recursos para o financiamento de planos e estudos de desenvolvimento local integrado, entendido como um planejamento compreensivo, em nível regional e municipal, englobando os aspectos econômicos, sociais, físicos e institucionais. A idéia de criação de um fundo para financiar o planejamento urbano já vinha desde o início do governo militar, tendo sido apresentada ao então recém-criado SERFHAU no final de 1964. Em junho de 1965, foi criado o Setor de Planejamento Regional e Municipal no Ministério do Planejamento e Coordenação Econômica. Pouco depois,

\begin{abstract}
"uma reunião promovida pelo Centro BNDE/CEPAL realizada em Quitandinha, evidenciou a necessidade do planejamento em escala micro-regional e, em decorrência disso, o setor de Planejamento Regional e Municipal, do Ministério do Planejamento, elaborou e apresentou um esboço de um Sistema Nacional de Planejamento Local Integrado" (COLE, 1967:13)
\end{abstract}

Porém, foi apenas durante o governo do general Costa e Silva, quando dirigido pelo arquiteto Harry James Cole, que o SERFHAU tornou mais efetiva sua ação, utilizando o FIPLAN para financiar planos diretores. Cole era membro do Instituto de Estudos e Pesquisas Econômicas Aplicadas (EPEA), órgão do Ministério do Planejamento, cuja equipe inicial foi constituída por planejadores ligados ao então ministro e um dos principais ideólogos do novo regime, o economista Roberto Campos, havia participado da elaboração do Sistema Nacional de Planejamento Local Integrado, um trabalho que procurou identificar homogeneidades regionais e que serviu de base para outros estudos que delinearam diretrizes para uma política urbana nacional. (LAFER, 1975)

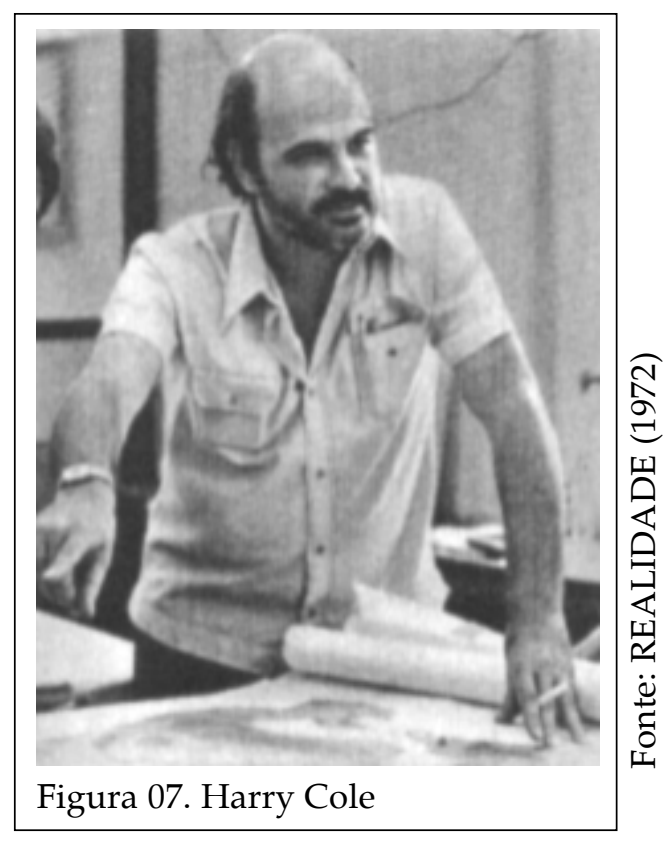


A idealização deste Sistema teve como ponto de partida os debates realizados no "Seminário sobre Pólos de Desenvolvimento", realizado em meados de 1966 no Recife, que contou com a orientação do geógrafo francês Michel Rochefort, para discutir as teorias sobre a metodologia a adotar na identificação de pólos de desenvolvimento e pólos de crescimento e para a caracterização de regiões homogêneas. Segundo COLE, "a partir dos estudos então realizados, o Escritório de Pesquisa Econômica Aplicada - EPEA e o Conselho Nacional de Geografia - CNG realizaram um estudo de caráter nacional para a identificação das microregiões e dos espaços homogêneos." (COLE, 1967:14)

Tend o como base estas idéias, os principais planos elaborados pelo regime militar, como o Plano de Desenvolvimento Estratégico, no governo Costa e Silva, buscavam traçar linhas de ação para as cidades organizadas hierarquicamente, no sentido de reduzir desigualdades regionais e também reduzir a migração para os grandes centros urbanos. Para as cidades, a proposta do sistema de planejamento local integrado tinha como objetivo racionalizar os investimentos no desenvolvimento urbano. $\mathrm{O}$ financiamento dos planos de desenvolvimento integrado tinha como principal fonte $o$ FIPLAN, com recursos provenientes basicamente do orçamento do BNH. Inicialmente, era realizado um Estudo Preliminar, para verificar a conveniência ou necessidade de desenvolvimento do Plano de Desenvolvimento Local Integrado, visando principalmente os municípios com mais de 50 mil habitantes, ou seja, havia uma ênfase, embora não explicitada criteriosamente, nas maiores cidades. (LAFER, 1975)

A orientação do SERFHAU para a elaboração dos planos acrescentava aos aspectos físicos e territoriais dos planejadores urbanos, as dimensões sócio-econômicas do desenvolvimento urbano. O funcionamento do SERFHAU como instituição de planejamento era principalmente como órgão prestador de assistência técnica, limitado à formulação de regras, normas e linhas de ação, ao financiamento, assessoria, apoio e controle técnico, cabendo aos próprios municípios elaborar os seus planos, contando com o apoio de empresas privadas de consultoria. A realização dos Planos com o apoio de empresas privadas e profissionais externos à administração municipal é um movimento que se inicia também anteriormente ao regime militar, desde os anos 1950. (FELDMAN, 2005a).

Dentro do SERFHAU,

"duas tendências se destacaram: os favoráveis a contratação de escritórios e técnicos para a elaboração dos Planos Diretores e os que preferiam formar pessoal dentro das próprias prefeituras e dar à gestão urbana as características de um processo de planejamento. Durante a fase autoritária, nas décadas de 60 e 70, os municípios em sua maioria, conservaram o processo de eleição democrática." (LAMPARELLI e ZAN: 1989:112)

Maria Adélia de Souza, que foi gerente do SERFHAU, enfatiza este embate interno entre as duas tendências: "Planos Diretores não podem ser feitos por consultorias privadas porque são documentos políticos. É anti-ético o setor privado ter conhecimento de uma estratégia ligada ao interesse público." (VIZIOLI, 1989:69) 
Com a imposição, durante certo período, da contratação de empresas de consultoria, o trabalho de planejamento e do próprio Plano Diretor passava a evidenciar uma contradição: impor um sistema de planejamento sobre as ações de governantes municipais que precisavam fazer política eleitoral e, ao mesmo tempo, conviver com o autoritarismo nas esferas superiores, o que propiciou ocorrer uma situação híbrida. Os escritórios de consultoria, além da elaboração do Plano, passaram também a treinar equipes locais. (LAMPARELLI e ZAN, 1989)

O fato de estabelecer acordos de cooperação técnica com organismos e empresas de consultoria internacionais (Universidade de Edimburgo, OEA, França, Espanha, dentre outros) fez com que sua influência sobre a formação dos técnicos do SERFHAU se traduzisse em normas e metodologias mais rígidas, exploradas em manuais cada vez mais abrangentes, onde o significado político das decisões é na maioria das vezes deixado de lado. (SOUZA, 1987)

Mas quais eram os processos de trabalho previstos pelo SERFHAU ? Inicialmente, eram previstas duas etapas consecutivas para orientar o planejamento local: o Estudo Preliminar (ou Relatório Preliminar - RP) e o Plano de Desenvolvimento Local Integrado (PDLI), independentemente do porte e característica do município que, posteriormente, se desdobrou em três, incluindo-se entre os dois anteriores, o Plano de Ação Imediata (PAI). A caracterização geral destes documentos pode ser assim reconhecida, segundo BRASIL-Minter (1971) e ZAHN (1981):

\footnotetext{
Relatório Preliminar: é um instrumento de caráter operacional e prospectivo destinado a municípios de pequeno porte, podendo ser considerado um plano de urgência, para comunidades mais carentes de recursos e também como um instrumento de sensibilização para iniciar um processo de planejamento.

Plano de Ação Imediata: é um instrumento destinado a municípios de médio porte, que compreende a elaboração de um diagnóstico, um plano de diretrizes gerais de desenvolvimento e um plano de ação do governo municipal, com ênfase nos aspectos físicos, territoriais e institucionais. Ou seja, seu conteúdo é mais amplo, globalizante, que permite a implantação das diretrizes e capacite a administração local a instaurar o planejamento de forma permanente integrado.

Plano de Desenvolvimento Local e Integrado: instrumento semelhante ao Plano de Ação Imediata, destinado as capitais estaduais e centros urbanos de importância nacional, que inclui a implantação de um sistema local permanente de planejamento.
}

Além destes tipos básicos de planos, o SERFHAU definiu ainda procedimentos que orientassem o planejamento micro-regional, visando atender interesses comuns de municípios limítrofes. A realização dos Planos dependia da prévia realização de um Termo de Referência, visando caracterizar a situação local e identificar informações disponíveis para uso posterior nos Planos. (BRASIL-Minter, 1971)

Em linhas gerais, a metodologia proposta pelo SERFHAU previa a sistemática seguinte, com pequenas variações quanto ao nível de profundidade, com a recomendação expressa de colaboração da equipe local e a discussão e avaliação do processo com a participação das autoridades e lideranças locais: 
- estruturação de um conjunto de informações através de coleta de documentação e da realização de levantamentos locais (incluíam os elementos disponíveis no local, tais como plantas aerofotogramétricas, dados estatísticos sociais e institucionais, aspectos históricos, estudos sobre a situação econômicofinanceira, estudos setoriais, plano diretor porventura existente, etc);

- realização de diagnósticos e prognósticos da situação local (caracterização dos problemas apurados dentro dos diversos aspectos municipais, isto é, os econômicos, sociais, físico-territoriais, administrativos, financeiros, políticos e legais, apresentados nas formas de diagnósticos sócio-econômicos, institucional, serviços públicos e estrutura urbana, com descritores, bem como previsão aproximada das alternativas possíveis para o desenvolvimento local e indicação sumária das medidas de curto prazo, composto de um prognóstico dos aspectos locais preponderantes à compreensão do futuro micro-regional, da estrutura urbana e suas tendências de crescimento, com as respectivas plantas);

- proposição de hipóteses de desenvolvimento e formulação das diretrizes correspondentes;

- indicação das medidas a serem tomadas pela administração, consubstanciando um plano de ação governamental (BRASIL-Minter, 1971) e (ZAHN, 1981).

A orientação metodológica do SERFHAU foi estabelecida através de diferentes instruções normativas de planejamento, estabelecendo objetivos para um conhecimento geral do Município, identificação dos problemas e dos agentes de desenvolvimento local, propor formas de atuação, sensibilizar autoridades e lideranças para o planejamento. Uma característica básica da metodologia proposta era o enfoque integral e integrado do plano, ressalvando-se a prevalência dos aspectos físico-territoriais e administrativos sobre os aspectos sócio-econômicos (BRASIL-Minter, 1971) e (ZAHN, 1981).

Os chamados Planos de Ação Imediata deveriam ser

\begin{abstract}
"elaborados a partir do conhecimento do contexto específico de cada município e, principalmente, da avaliação da capacidade operacional, real e possível, das Prefeituras, sobretudo com relação à solução de problemas locais objetivamente conscientizados pela comunidade e pelas autoridades municipais, em termos de reivindicações e proposições político-administrativas, quando julgadas aceitáveis do ponto de vista técnico. A resultante dos Planos de Ação Imediata deverá ser a institucionalização, nos municípios selecionados, de efetivos sistemas de ordenamento da ação governamental, de controle e de harmonização do desenvolvimento municipal." (BRASIL-Minter, 1971:5)
\end{abstract}

De modo geral, a sistemática adotada previa a estruturação das informações através da coleta de dados em documentos e a realização de levantamentos locais, o diagnóstico e o prognóstico da situação, a proposição de hipóteses de desenvolvimento e formulação de diretrizes, e a indicação das medidas a serem tomadas pelo governo local, bem como a obrigatoriedade de realizar seminários de avaliação (BRASIL-Minter, 1971)e (ZAHN, 1981). 
Considerava-se ainda de natureza obrigatória a elaboração de um Cadastro Técnico Municipal, enquanto um instrumento básico e indispensável para a continuidade do planejamento integrado ao nível municipal, onde a problemática urbana é predominante. Também os programas de capacitação da administração, atualização ou elaboração da legislação municipal básica, tributária e urbanística, treinamento e capacitação de recursos humanos, reestruturação do quadro de pessoal da prefeitura, regulamentação das atividades e rotinas administrativas, para simplificá-las. E fundamentalmente, como exigência para obtenção do financiamento feito pelo SERFHAU, como objetivo de institucionalizar definitivamente o processo, havia a obrigatória criação de um órgão municipal de planejamento. (ZAHN, 1981)

Em 1969, a instituição do Programa de Ação Concentrada (PAC) pelo Ministério do Interior (através da portaria $\mathrm{n}^{\circ}$. 214, do Ministério do Interior, editada em 11 de junho daquele ano), estabeleceu critérios mais claros de seleção dos municípios que deveriam participar do Programa e receber financiamentos para promover um plano de desenvolvimento integrado, selecionando-se 457 deles, com base nas micro-regiões estabelecidas pelo IBGE, incluindo-se as cidades mais populosas de cada micro-região e as de população superior a 20 mil habitantes. (CINTRA e HADDAD, 1978)
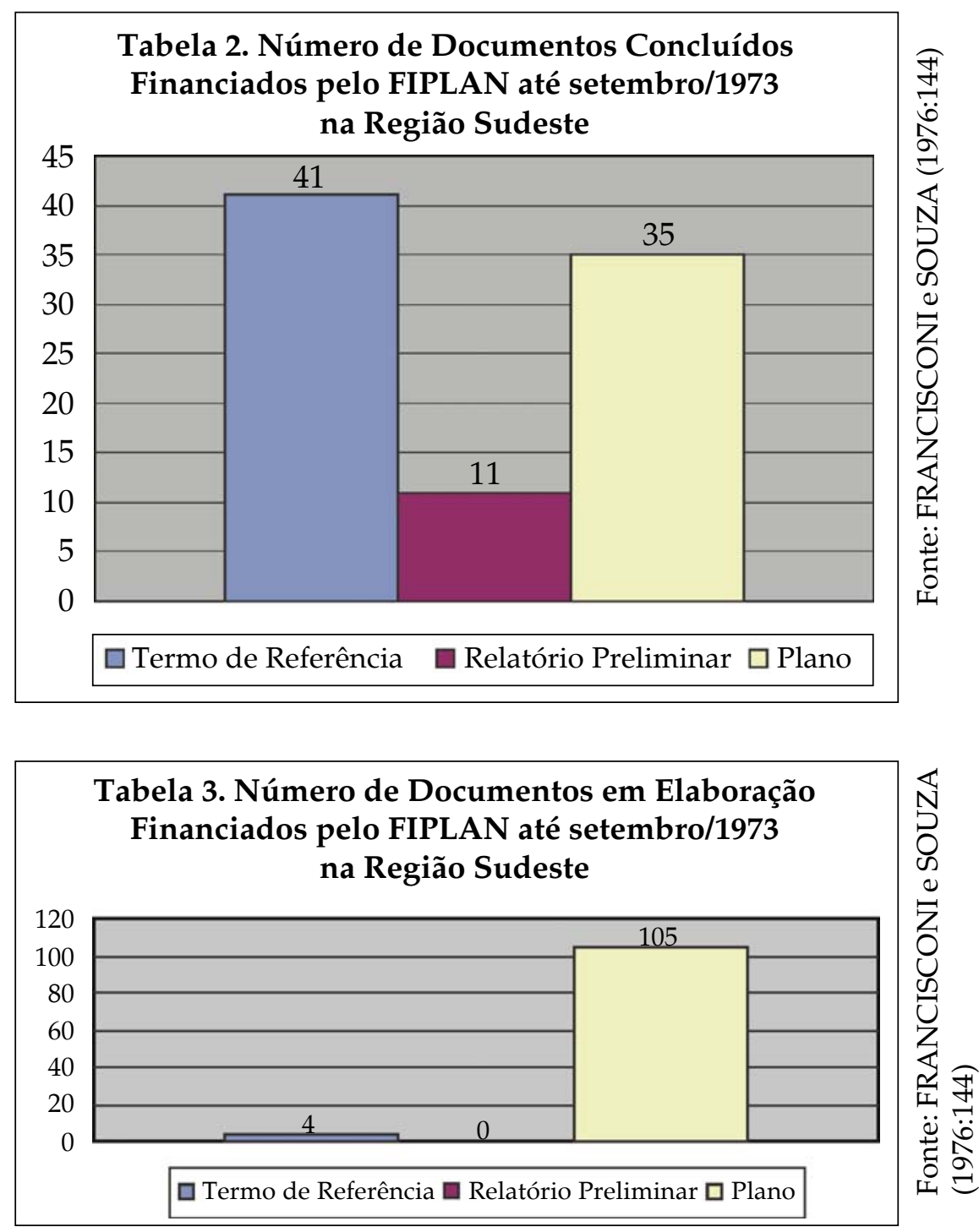


\title{
A INCLUSÃO DE FRANCA NO FINANCIAMENTO DOS PLANOS DIRETORES DE
} DESENVOLVIMENTO INTEGRADO PELO SERFHAU

\begin{abstract}
Considerando o sistema urbano paulista naquele momento, pode-se dizer que conteria

"um núcleo central, representado pela cidade de São Paulo e suas extensões até Franca, Ribeirão Preto, Bauru, Sorocaba e ao longo da via Dutra até o Rio de Janeiro, compondo um sistema com características de verdadeira hierarquia urbana apoiada em complexo urbano e industrial e uma periferia imediata do núcleo central, composta de centros urbanos de menor diversificação industrial, principalmente no oeste paulista" (AMBROSIS e MOREIRA, 1977:10).
\end{abstract}

As políticas de desconcentração industrial elaboradas pelo governo militar ganham força, com o objetivo de evitar o crescimento excessivo das aglomerações urbanas metropolitanas, principalmente na concepção advinda do II Plano Nacional de Desenvolvimento - PND, com o intuito de orientar o esforço de desconcentração para as cidades de porte médio-grande no interior paulista que apresentam potencialidades de localização. (AMBROSIS e MOREIRA, 1977)

Franca, uma cidade antiga, consolidada e em expansão populacional e industrial, considerada de porte médio conforme os critérios adotados pelos estudos governamentais, espacialmente localizada na extremidade da extensão de um dos braços deste núcleo central de urbanização e industrialização paulista, se inclui claramente no modelo de desconcentração industrial imaginado pelo planejamento governamental. O próprio financiamento do SERFHAU ao município para elaborar seu Plano Diretor é um indicador desta sua inclusão no modelo. Portanto, foi provavelmente com base nos critérios adotados pelo governo que Franca foi uma das cidades selecionadas para o desenvolvimento do seu Plano Diretor, inclusive porque já havia sido escolhida anteriormente para a realização de um Estudo Preliminar, o que pode explicar o financiamento obtido pela Prefeitura local para a contratação de uma empresa privada de consultoria (o GPI) ainda em 1967, antes mesmo da criação do PAC, além do município possuir um órgão de planejamento desde o início de 1964.

O contrato de financiamento com Franca, beneficiando uma população estimada em 67.287 habitantes no segundo semestre de 1968, apontava o valor dispendido até aquele momento em CR\$ 138.5150024 (SERFHAU, 1970:8).

O discurso oficial do governo para justificar o processo de planejamento integrado e seu financiamento pelo PAC, expresso através do Banco Nacional de Habitação $\mathrm{BNH}$, que financiava os planos através do SERFHAU, dizia que estavam

"fazendo urbanização mais desenvolvimento urbano, isto é, urbanização sem marginalização, com melhoria da qualidade de vida. Muita gente ainda não pode avaliar bem a qualidade de vida que se dá,

\footnotetext{
${ }^{24}$ Conforme a tabela vigente do Tribunal de Justiça do Estado de SP, o valor atualizado monetariamente corresponderia hoje a aproximadamente $\mathrm{R} \$ 160.000,00$.
} 
por exemplo, em Franca ou Ribeirão Preto. Esta não é nenhuma região subdesenvolvida, é uma região rica do Estado de São Paulo." (TRINDADE: 1971:30)

Para atingir esses objetivos, afirmava-se ainda que

“o Plano de Ação Concentrada do Ministério do Interior foi o primeiro passo para definir os pólos de desenvolvimento dos núcleos para elevação e propagação desse processo em todo o ecúmeno brasileiro. O PAC está em pleno andamento em cerca de 450 municipalidades, provendo a reorganização administrativa, provendo o planejamento do desenvolvimento local integrado, os sistemas de água e esgotos, a habitação e o desenvolvimento comunitário. Estão sendo atendidas, assim, aquelas necessidades fundamentais que viabilizarão a transformação a que nos referimos, ao mesmo tempo em que se planeja o desenvolvimento em micro-regiões e o desenvolvimento regional integrado no grande planejamento da ocupação ordenada do território brasileiro." (TRINDADE:1971:33)

O processo de desenvolvimento econômico dos anos anteriores ao golpe militar revelou, através de bem conhecidas conseqüências, os obstáculos ao desenvolvimento posterior. "Castelo Branco e o grupo seleto de formuladores de políticas que atraiu para os altos cargos executivos e de assessoria em seu Governo consideravam grande parte de sua missão a modernização e a revisão das instituições, pelo abandono das estruturas arcaicas e pela criação de instrumentos mais compatíveis com o sistema de livre mercado que pretendiam consolidar." (CINTRA e HADDAD, 1978:211)

Tais tarefas, como se verifica, são contraditoriamente conflitantes com a estruturação de um processo de planejamento nacional, pois de alguma forma a política urbana decorrente de um processo de planejamento acabaria assumindo formas de transferência entre classes sociais, de caráter redistributivo.

A visão de planejamento no início do regime militar, quando da criação do SERFHAU, decorreria então de um conjunto de interesses e de grupos, a saber:

a) "a inspiração pró-planejamento do regime;

b) a preocupação com as cidades, decorrente do seu locus de descontentamento popular, nos últimos anos do populismo, e que portanto ensejaria ações de governo para sua superação;

c) o surgimento de áreas metropolitanas, a "guerra fiscal" decorrente da concorrência entre municípios, a desigualdade de recursos entre os municípios, as externalidades que exigem uma estrutura reguladora e políticas integradas, por parte dos agentes externos, estaduais e federais.

d) a necessidade de efetuar investimentos em infra-estruturas urbana como pré-requisito para investimentos produtivos, dificultando a mera ação local;

e) o estabelecimento de critérios para ajuda federal, com crescente demanda e recursos escassos; 
f) o impacto decorrente da ação do BNH nas estruturas urbanas, que reclamavam planejamento territorial;

g) a preocupação dos militares com a integração nacional, a ocupação do interior do país e o crescimento regional integrado, num processo de interiorização do desenvolvimento;

h) o interesse do Ministério do Interior em adquirir maior prestígio e poder institucional;

i) a presença de um grupo articulado e ativo de arquitetos-planejadores, fazendo constante pressão em favor de uma política de planejamento, sempre chamando a atenção para o que consideram distorções e anomalias do processo de urbanização do país." (CINTRA e HADDAD, 1978:217)

Pode-se observar nitidamente no período entre 1967 e 1977, que houve um movimento de centralização de recursos, do poder normativo e político nas mãos do governo federal, permitindo-lhe a montagem de mecanismos de alocação de recursos e investimentos segundo os objetivos do governo militar, em padrões que ele considerava prioritários e necessários, bem como um amplo movimento de descentralização da execução das políticas de desenvolvimento urbano, motivadas principalmente pela complexidade e escala das mesmas. Ou seja, ocorreu um movimento duplo, de centralização de poder e, ao mesmo tempo, de descentralização da atuação direta, seguindo uma lógica que estrutura um modelo empresarial. Fica clara a opção pela implantação de métodos modernos de gestão, aos moldes empresariais e a introdução de nova tecnologia para elaborar o orçamento público, de gestão e controle utilizadas pelas empresas privadas. De outro lado, uma certa descentralização permitiu também a estruturação e a atuação de empresas privadas na produção do ambiente construído, não somente de equipamentos e serviços públicos, mas também de novos espaços para o setor privado. (LAMPARELLI e CAMARGO, 1978)

A estruturação de um modelo denominado central-desenvolvimentista se consolida durante o período do regime militar, de grande crescimento econômico e de ampliação da desigualdade social, onde o planejamento urbano seria marcado por diversas características, dentre elas as identificadas como:

- autoritarismo;

- centralização da gestão; ausência de participação - em qualquer nível - dos usuários e da sociedade em geral;

- desarticulação das políticas setoriais;

- priorização do transporte individual;

- preferência pelas grandes obras, às vezes desnecessárias, canalizando recursos públicos para empreiteiras e relegando a segundo plano as iniciativas na área social. (BONDUKI, 1998)

Para o regime militar, o momento era propício para implementar as medidas ditas racionalizadoras e modernizadoras das instituições e da gestão pública municipal, 
pois se estava em pleno período do chamado "milagre econômico", de grande crescimento da economia brasileira. O planejamento urbano é pensado, neste contexto, a partir do seu papel no projeto desenvolvimentista do regime militar, deixando clara a concepção de que os "problemas urbanos" poderiam ser resolvidos através de uma administração mais "racional", onde o planejamento compreensivo teria um papel fundamental, modernizador. Desta forma, a questão urbana perderia seu caráter político e ganharia ênfase a visão tecnicista, de "neutralidade" do planejamento. (RIBEIRO e CARDOSO, 1990)

É a partir deste debate que se colocam os princípios desenvolvidos pela tecnoburocracia que predominava nos organismos públicos, estabelecendo-se hegemonicamente a idéia-força de que as cidades deveriam ter um Plano Diretor que orientasse seu crescimento, apesar de todas as contradições existentes, inclusive dentro do próprio corpo técnico do SERFHAU.

Embora os números possam ser parciais ou incompletos, o esforço do SERFHAU em elaborar os Planos Diretores municipais e o planejamento integrado por todo o território nacional, contudo, não deixa de ser notável: até sua liquidação, no final dos anos 70, o SERFHAU efetuou o financiamento, com recursos do FIPLAN, de 27 Planos Diretores de Desenvolvimento Integrado, 21 Planos de Ação Imediata, 32 Cadastros Técnicos Municipais, 172 Relatórios Preliminares e 3 Planos Metropolitanos de Desenvolvimento Integrado. (PAOLI, 1981)

\section{A CRÍTICA GENERALIZADA AO PLANO DIRETOR COMO PEÇA DE FICÇÃO}

Qual teria sido o resultado de todo este esforço de introduzir nas administrações um processo de planejamento governamental? Estudos realizados após a extinção do SERFHAU mostram, no caso do estado de São Paulo, que boa parte dos chamados municípios pólo elaboraram seus planos, porém não os teriam implantado. Os planos teriam se constituído sobretudo de diagnósticos, mas seriam pouco operacionais, não condizentes com a capacidade local, principalmente de recursos financeiros e humanos, para sua implantação. Seu conteúdo evidenciaria setorização e enfoque nitidamente urbano muito acentuado, contradizendo a integração pretendida pelos chamados Planos Diretores de Desenvolvimento Integrado. Os numerosos organismos de planejamento dos municípios que foram criados no período do SERFHAU, nem sempre teriam existência de fato ou desempenhavam tarefas cotidianas que não se diferenciavam das atividades tradicionais da administração municipal, não se constituindo efetivamente no processo de planejamento local integrado desejado pelo Plano. (AZEVEDO, 1976)

As ações dos governos municipais implementadas com o apoio do SERFHAU teriam se resumido, praticamente, a um esforço de capacitação interna das Prefeituras, em geral no campo administrativo, privilegiando a criação de estruturas formais e processos internos de organização e métodos. No campo específico do urbano, teria sido dada ênfase à edição de normas de controle urbanístico, principalmente de zoneamento de uso do solo, nos moldes do racional-funcionalismo. ( GONDIM, 1991) 


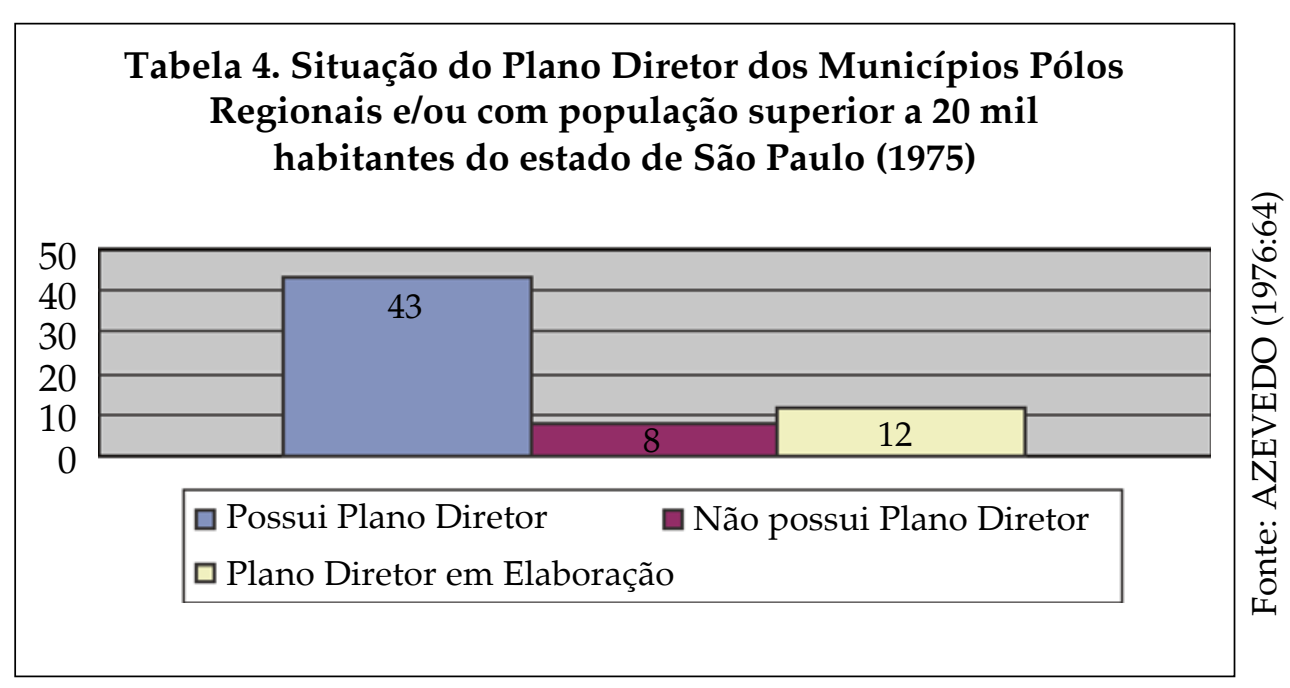

Mais ainda, a ênfase dada pelo BNH, que geria os recursos do Sistema Financeiro de Habitação - SFH, às suas funções econômicas e financeiras e o impacto decorrente das inúmeras políticas públicas em andamento que influenciavam o processo de urbanização, como a localização industrial, as políticas agrárias, a política fiscal e monetária, de transporte e outras que interferiam na estrutura e crescimento do espaço urbano e que, mesmo previstos nos Planos, não tinham como integrar-se, ficando ao largo do processo político de tais decisões. (IANNI, 1971)

Outro dos principais problemas apontados pela crítica às formulações do SERFHAU é que, na prática, pela forma com que os trabalhos teriam sido efetuados na época, contratados por município, a cidade acabava sendo vista como um organismo autárquico, isto é, suas ligações com outras cidades e regiões praticamente não eram levadas em conta, era como se fossem cidades isoladas, desconectadas umas das outras. Como não havia planos regionais efetivamente colocados em prática, embora isto aparecesse como uma das preocupações do SERFHAU, não havia complementaridade entre os Planos dos diversos municípios próximos entre si:

\begin{abstract}
"a falta de objetivos mais precisos (dos Planos), a inconsistência entre as proposições dos planos e os instrumentos controlados pelas autoridades locais e a descontinuidade administrativa estão entre as principais causas das dificuldades encontradas para a implantação dos Planos. Além do mais, a maioria dos Planos Locais ficava limitada a diagnósticos das economias municipais". (LODDER: 1978:133)
\end{abstract}

No nível intra-urbano, outra idéia chave no período, a da necessidade de organização das cidades, do seu ordenamento territorial e do planejamento urbano, não conseguiu fazer com que os Planos Diretores previssem medidas de peso para reverter o fluxo migratório e a situação de verdadeira espoliação urbana presente nas cidades brasileiras no período, atendendo os interesses dos setores do capital imobiliário e industrial interessados no crescimento urbano. (BRASILEIRO,1981) 
Há, portanto, uma confluência da crítica quanto ao fracasso do SERFHAU e dos Planos Diretores financiados, pelos mais diferentes motivos. Assim, é a efetividade do Plano Diretor, enquanto instrumento de ação concreta do poder local que se pretende discutir, a partir da crítica mais contundente ao fenômeno, explicitada principalmente por VILLAÇA (1999 e 2005), um dos autores que mais profusa e profundamente debateram e analisaram recentemente a questão.

O conceito de plano diretor, seja na modalidade físico-territorial ou outra, desenvolveu-se no Brasil mais ou menos a partir da metade do século XX, muito embora a expressão "plano diretor" já aparecesse no Plano Agache de 1930, realizado para o Rio de Janeiro. Discutido no Brasil em universidades, nos órgãos legislativos municipais, em seminários, congressos e conferências acadêmicas, em instituições públicas municipais, estaduais e federais, haveria um empenho da sociedade, um gasto de energia social para debater algo que não existe, pois esse Plano Diretor, sempre sob a ótica de VILLAÇA, seria apenas "uma criação da razão pura, uma construção mental baseada na idéia pura descolada da realidade social", em função da inefetividade deste instrumento no planejamento urbano. Ou melhor, para este autor, seria mesmo uma ilusão tentar estudar a ação do Estado brasileiro por meio dos planos diretores, dos seus documentos ou por intermédio do discurso dominante sobre o planejamento urbano estatal. O planejamento urbano, pelo menos durante cinqüenta anos, entre 1940 e 1990, período em que sua idéia central está colocada no chamado Plano Diretor, não teria atingido os objetivos que lhe foram atribuídos, a maioria absoluta dos planos diretores foi parar nas gavetas e prateleiras, como meras obras de referência. Seus resultados seriam pífios e marginais aos próprios planos e à vida das cidades que pretendiam modificar. O planejamento urbano não teria sido uma atividade orientadora ou uma carta de compromisso do Estado em qualquer dos níveis de governo, não teria sido capaz de produzir "concepções de cidade" "ou pressupostos urbanísticos", "estratégias" ou "políticas públicas". Coloca-se, portanto, um grave problema para a própria história do planejamento, pois o discurso do planejamento seria apenas de uma manifestação ideológica que a classe dominante e o Estado difundem, não havendo possibilidade de levá-lo a sério, acreditar que os planos foram elaborados com a real intenção de modificar o quadro de precariedade urbana, de atingir objetivos estratégicos e de desenvolvimento harmônico e integrado. (VILLAÇA, 1999)

Mais ainda, desde que a idéia do Plano Diretor surgiu no Brasil há mais de setenta anos atrás, não se conheceria qualquer cidade brasileira ou qualquer administração municipal que tenha sido minimamente pautada, ainda que por poucos anos, por um Plano Diretor com um nível de abrangência, ambições e objetivos que ultrapassassem significativamente os do zoneamento. (VILLAÇA, 2005)

Seriam poucas, portanto as realizações do SERFHAU. Seu esforço para atingir os objetivos que lhe foram legalmente atribuídos estaria condenado ao mais completo fracasso.

"Em primeiro lugar, faltava-lhes consistência teórica e administrativa.

Os planos se tornariam adornos de estantes não apenas por não 
constituírem marcos de referência para programas setoriais, mesmo quando financiados pelo $\mathrm{BNH}$, mas também pela própria concepção, que tendia, ao confiar a formulação de planos a empresas privadas, a separar as alternativas técnicas das escolhas políticas e da execução. Entre outras falhas, os planos assim produzidos tendiam a superestimar, de modo às vezes irresponsável, a capacidade de investimento dos municípios. Assim sendo, quando da mudança dos prefeitos, o irrealismo dos planos podia aumentar a relutância dos novos governantes em executar programas de seus antecessores." (CINTRA e HADDAD,1978:124)

Assim, pode-se afirmar, sem sombra de dúvida, que a literatura em geral e alguns autores em especial, apontam a política adotada pelo SERFHAU como um rotundo fracasso, principalmente sua concepção do Plano Diretor de Desenvolvimento Integrado como um instrumento de planejamento das cidades brasileiras do período, basicamente decorrente de sua confecção tecnoburocrática, da ausência de participação e voz da sociedade civil, em boa parte decorrente ou atribuída ao autoritarismo e a centralização política vigentes à época.

Esta crítica, ao identificar o planejamento integrado ou compreensivo com o regime militar, dedica-se a expor a sua natureza como intrinsecamente autoritária e a sua ineficácia. Estas questões remetem à necessidade de discutir se essa integração ou compreensividade, ou sua dosagem de racionalidade, são realmente de natureza autoritária (e por extensão, exclusivas do regime militar), ou se a necessária análise crítica da complexidade do urbano exige esta "racionalidade" ou "compreensividade/ integração" na ação estatal, inclusive na democracia. Até mesmo porque, em termos metodológicos, não se tem ainda a avaliação de experiências mais recentes e testadas o suficiente para alterar de forma radical e integralmente as estruturas estabelecidas na década de 1960 pelo SERFHAU.

Desta forma podemos, sem esgotar o assunto, estabelecer e alinhar um conjunto de críticas gerais aos Planos Diretores do período:

- Os planos se resumiam a um diagnóstico exaustivo e pouco operacional;

- Os planos produzidos por empresas privadas seriam tecnocráticos, excluindo a política de sua concepção e horizontes;

- Os planos seriam irreais, não contemplavam os interesses da sociedade local, também por sua concepção tecnocrática;

- Os planos não verificavam a capacidade de investimento dos municípios, tornando-se inexequíveis;

- A exigência de implantação de organismos municipais de planejamento não se traduziu em implantação do processo de planejamento nas prefeituras;

- Os planos eram desconectados da região onde se inseriam os municípios;

- Os planos se resumiam basicamente ao zoneamento de uso e ocupação do solo. 
Para alguns autores, no entanto, dizer que os planos foram feitos exclusivamente por tecnocratas alienados e distanciados da realidade local e da sociedade civil não corresponde totalmente à realidade. Determinados setores, que possuem interesses específicos na atuação do Estado, como empreiteiros de obras e serviços públicos, os representantes de entidades ligadas ao capital industrial e comercial local, que são da sociedade civil, esses geralmente são ouvidos, porque o Estado está estruturalmente organizado com sua presença, ou melhor, a escolha de agentes políticos públicos, como secretários municipais, presidentes de companhias e empresas estatais, geralmente, é feita em conjunto com a participação destes setores. (CAMPOS FILHO, 1981)

As observações de LAMPARELLI e ZAN (1989) apontam na mesma direção, ao enfatizar que, naquele período, a obsolescência de grandes áreas urbanas para atender as exigências das novas formas de produção e consumo decorrentes dos novos padrões de vida numa sociedade regida pelas leis de mercado foi caracterizada por um esforço de transformação do espaço urbano, buscando estabelecer novos moldes de produção e de acumulação do capital. O discurso do regime militar, porém, não deixava transparecer os privilégios decorrentes de suas ações com o capital. De um lado, o discurso do planejamento integrado, programando ações que atendessem todas as atividades humanas e, de outro, a prática, onde a escolha dos projetos e programas a serem realizados dependia da relação de forças políticas num contexto ditatorial. $\mathrm{Ou}$ seja, os Planos Diretores eram praticados parcialmente e privilegiavam os interesses da classe dominante,

"por isso eles aparecem como um grande fracasso quando avaliados pela população, por analistas com sensibilidade social e pelos indicadores sociais. Pode-se afirmar, de maneira geral, que não é no âmbito do Plano Diretor que se solucionam questões relevantes, como desigualdades sociais e distribuição de renda" (LAMPARELLI e ZAN: 1989:112).

Quanto à caracterização do Plano Diretor do período do SERFHAU como um instrumento de ficção, ineficaz, ineficiente, produto apenas da razão, com seu diagnóstico excessivo, extensivo e irreal dos problemas urbanos, em função da ausência de participação social em sua elaboração e da ação de uma tecnoburocracia que substitui completamente a política, caracterização baseada principalmente na investigação de experiências metropolitanas e na identificação de um suposto "pecado original" por sua origem no regime militar, a crítica corrente à atuação do SERFHAU incorre numa generalização do resultado dos Planos Diretores de Desenvolvimento Integrado que não foi substantivamente estudado e avaliado, em parte porque os processos deflagrados pelos planos diretores são longos e, provavelmente, diferenciados de município para município. Portanto, utilizar um estudo de caso como o de Franca permite vislumbrar em que medida a generalização das análises, geralmente focadas em cidades metropolitanas, admite a inefetividade dos Planos e pode contribuir para um avanço das análises sobre o planejamento das cidades brasileiras.

Como veremos nos capítulos seguintes, no caso de Franca, a pecha de total ineficácia dos Planos Diretores não pode ser generalizada, pois os resultados obtidos a 
partir do processo que instituiu o Plano Diretor local indicam, no mínimo, ter sido incorporado à administração pública um processo de planejamento e capacidade de negociação, em parte obtida através da constituição e consolidação de uma estrutura tecnoburocrática, em parte pelo Plano indicar a definição coerente de um rumo, um caminho para a cidade se expandir (o que não é pouco, ainda que de forma não linear no tempo) que atendia prioritariamente os interesses do setor industrial local, fração predominante do capital local naquele período e com forte presença no poder político do município, ao modo como descrevem LAMPARELLI e ZAN (1989).

O significativo conjunto de obras e investimentos realizados pelo município, a partir do Plano Diretor, prepararam a cidade para se transformar numa plataforma física da expansão e consolidação de sua indústria calçadista, ao mesmo tempo que aquilo que o Plano propunha e que poderia obstaculizar este objetivo, não se concretizou, como a limitação para sua expansão horizontal e um zoneamento mais rígido de uso do solo. 


\section{Quadro 1 - Resumo dos principais dirigentes governamentais do Executivo Municipal de Franca (1964-2004) vinculados ao Plano Diretor}

\begin{tabular}{|c|c|c|c|c|}
\hline Período & Prefeito & Partido & $\begin{array}{c}\text { Assessor/Secretário } \\
\text { Planejamento }\end{array}$ & Observações \\
\hline 1964-1969 & $\begin{array}{l}\text { Hélio } \\
\text { Palermo }\end{array}$ & $\begin{array}{l}\text { PSD- } \\
\text { Arena }\end{array}$ & Luiz do Couto Rosa & $\begin{array}{l}\text { Palermo havia sido vereador, pelo partido de } \\
\text { Adhemar de Barros, nas duas legislaturas } \\
\text { anteriores. Era professor primário, economista e } \\
\text { industrial calçadista. Após o encerramento de sua } \\
\text { primeira gestão, retornou à direção da sua indústria } \\
\text { de calçados, mas não abandonou a política. } \\
\text { Retornou à Prefeitura em 1973, falecendo em 1977, } \\
\text { logo após o final do seu mandato. } \\
\text { Rosa era arquiteto sem vinculação partidária, } \\
\text { servidor do quadro efetivo da Prefeitura. }\end{array}$ \\
\hline 1969-1973 & $\begin{array}{c}\text { José Lancha } \\
\text { Filho }\end{array}$ & $\begin{array}{l}\text { MDB- } \\
\text { Arena }\end{array}$ & Luiz do Couto Rosa & $\begin{array}{l}\text { Lancha Filho é médico, foi vereador e líder da } \\
\text { oposição a Palermo na legislatura anterior. Após } \\
\text { pressões políticas sofridas durante o mandato, sai } \\
\text { do MDB e entra na Arena. Somente retornou a um } \\
\text { cargo público em 1993, elegendo-se vereador e } \\
\text { tornando-se secretário municipal da Saúde até } \\
\text { 1996. Foi candidato a prefeito em 2000, mas não se } \\
\text { elegeu. }\end{array}$ \\
\hline 1973-1977 & $\begin{array}{l}\text { Hélio } \\
\text { Palermo }\end{array}$ & Arena & $\begin{array}{l}\text { Luiz do Couto Rosa } \\
\text { Antônio Sérgio M. } \\
\text { Arantes }\end{array}$ & $\begin{array}{l}\text { Rosa foi deslocado para a EMDEF, empresa pública } \\
\text { de infra-estrutura urbana criada em } 1975 . \\
\text { Arantes é arquiteto, sobrinho de Palermo. }\end{array}$ \\
\hline 1977-1983 & $\begin{array}{l}\text { Maurício } \\
\text { Sandoval } \\
\text { Ribeiro }\end{array}$ & $\begin{array}{l}\text { Arena- } \\
\text { PDS }\end{array}$ & $\begin{array}{l}\text { Fernando Bueno Ribeiro } \\
\text { José Ricardo Cunha } \\
\text { Gilberti } \\
\text { Alceu Rubens Morandini }\end{array}$ & $\begin{array}{l}\text { Sandoval Ribeiro é bancário, nunca tinha tido } \\
\text { qualquer participação política anterior, embora } \\
\text { pertencesse a família tradicional da cidade, é } \\
\text { sobrinho do ex-prefeito dr. Janjão. Elegeu-se } \\
\text { deputado estadual em 1986, pelo PTB e retornou à } \\
\text { prefeitura em 1989. Após o encerramento do seu } \\
\text { segundo mandato, abandonou a vida pública, } \\
\text { aposentando-se como bancário. } \\
\text { Bueno Ribeiro é economista. } \\
\text { Gilberti é engenheiro civil e empresário da } \\
\text { construção civil, cunhado de Maurício Sandoval } \\
\text { Ribeiro. } \\
\text { Morandini era economista, faleceu em } 2005 \text {. } \\
\text { Em 1977, Mauro Ferreira foi contratado pela } \\
\text { prefeitura como arquiteto, até 1983, quando } \\
\text { retornou à iniciativa privada. } \\
\text { Wilson Luiz Teixeira foi contratado pela prefeitura } \\
\text { como engenheiro civil em } 1978 \text {, tornando-se } \\
\text { servidor efetivo. Rosa permaneceu na EMDEF. }\end{array}$ \\
\hline
\end{tabular}




\begin{tabular}{|c|c|c|c|c|}
\hline Período & Prefeito & Partido & $\begin{array}{c}\text { Assessor/Secretário } \\
\text { Planejamento }\end{array}$ & Observações \\
\hline $1983-1987$ & $\begin{array}{l}\text { Sidnei } \\
\text { Franco da } \\
\text { Rocha }\end{array}$ & PMDB & Ary Pedro Balieiro & $\begin{array}{l}\text { Rocha é radialista e tornou-se empresário e } \\
\text { proprietário de emissora de rádio durante seu } \\
\text { mandato como prefeito. Foi assessor de Esportes } \\
\text { de Palermo na gestão 1973-1977. Elegeu-se vereador } \\
\text { em 1977, liderando a oposição pelo PMDB. Elegeu- } \\
\text { se prefeito em 1983. Afastou-se da Prefeitura em } \\
1986 \text { para assumir a Vasp, do governo estadual, } \\
\text { Candidatou-se a deputado estadual em 1990 e 1994, } \\
\text { assim como a prefeito em 2000, não se } \\
\text { elegendo.Teixeira permaneceu como engenheiro } \\
\text { civil da prefeitura. } \\
\text { Rosa permaneceu na EMDEF. } \\
\text { Arantes foi secretário de Obras em 1983, retornando } \\
\text { à iniciativa privada a partir de 1984 e nunca mais } \\
\text { retornou ao serviço público. }\end{array}$ \\
\hline $1987-1988$ & $\begin{array}{l}\text { Ary Pedro } \\
\text { Balieiro }\end{array}$ & PMDB & Wilson Luiz Teixeira & $\begin{array}{l}\text { Balieiro é arquiteto e foi empresário de loteamentos } \\
\text { e construção. Elegeu-se vereador pela Arena em } \\
\text { 1977 e migrou para o PMDB, na reforma partidária } \\
\text { de 1981. Foi vice-prefeito na chapa de Sidnei e } \\
\text { assumiu a secretaria de Planejamento em } 1983 . \\
\text { Substituiu Rocha como prefeito, após seu } \\
\text { afastamento em 1986. Posteriormente, elegeu-se } \\
\text { prefeito pelo PTB, em 1993. Foi candidato, não } \\
\text { eleito, a deputado federal em 1998. } \\
\text { Rosa permaneceu na EMDEF. }\end{array}$ \\
\hline 1989-1992 & $\begin{array}{l}\text { Maurício } \\
\text { Sandoval } \\
\text { Ribeiro }\end{array}$ & РTB & Wilson Luiz Teixeira & $\begin{array}{l}\text { Rosa permaneceu na EMDEF. } \\
\text { Ferreira foi assessor parlamentar do gabinete de } \\
\text { Dominici, sendo suplente a vereador pelo PT. }\end{array}$ \\
\hline 1993-1996 & $\begin{array}{l}\text { Ary Pedro } \\
\text { Balieiro }\end{array}$ & $\begin{array}{l}\text { PMDB- } \\
\text { PTB }\end{array}$ & Wilson Luiz Teixeira & $\begin{array}{l}\text { Ferreira foi assessor parlamentar do gabinete de } \\
\text { Dominici. } \\
\text { Rosa permaneceu na EMDEF, até sua } \\
\text { aposentadoria em 1994. Faleceu em 2004. }\end{array}$ \\
\hline $1997-2000$ & $\begin{array}{l}\text { Gilmar } \\
\text { Dominici }\end{array}$ & PT & Mauro Ferreira & $\begin{array}{l}\text { Dominici é assistente social, sendo eleito vereador } \\
\text { pelo PT nos dois mandatos anteriores. } \\
\text { Teixeira permaneceu na Prefeitura como } \\
\text { engenheiro. }\end{array}$ \\
\hline 2001-2004 & $\begin{array}{l}\text { Gilmar } \\
\text { Dominici }\end{array}$ & PT & Sérgio Simões & $\begin{array}{l}\text { Ferreira foi coordenador de planejamento } \\
\text { estratégico, responsável pelo novo Plano Diretor } \\
\text { da cidade. Teixeira permaneceu na Prefeitura como } \\
\text { engenheiro. }\end{array}$ \\
\hline
\end{tabular}




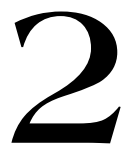

\title{
O LONGO PROCESSO DE ELABORAÇÃO E IMPLEMENTAÇÃO DO PLANO DIRETOR DE FRANCA
}

\begin{abstract}
"Apesar da consciência de que a neutralidade absoluta do historiador é utopia, buscou-se sinceramente toda a isenção possível. Inclusive mediante a diversificação de fontes escritas e orais, primárias e secundárias, com o objetivo de tentar neutralizar eventuais distorções provenientes de identificações pessoais ou ideológicas do autor com atores ou autores. E também que a influência decorrente de sua vivência pessoal de parte dos acontecimentos não comprometesse visão crítica e desapaixonada (...) Assim, além do lastro da bibliografia existente, de pesquisas e de documentos, este trabalho incorpora a própria experiência pública do autor (...) considera dezenas de depoimentos inéditos e exclusivos de atores políticos relevantes, que vivenciaram diretamente o processo e os acontecimentos." (COUTO, 1998:12)
\end{abstract}

A idéia de elaborar um Plano Diretor para a cidade de Franca não era nova quando foram iniciados os trabalhos da empresa GPI, contratada pelo prefeito Hélio Palermo em 1967 para elaborar um Plano Diretor de Desenvolvimento Integrado. Em 1950, havia sido aprovada a lei municipal $\mathrm{n}^{\circ}$. 116, de 16 de novembro, que autorizava expressamente o Poder Executivo a promover a sua elaboração, medida legislativa que, no entanto, não teve qualquer desdobramento prático.

Posteriormente, em 1960, quando aconteceu um primeiro contato entre a Prefeitura de Franca e o urbanista paulistano Anhaia Melo, sua necessidade era apontada pelas autoridades públicas e pela imprensa como um importante instrumento de ordenamento do crescimento da cidade. Anhaia Mello já havia passado pela região e 
iniciou tratativas para elaborar um plano diretor para Franca. Em fevereiro de 1960 o então prefeito de Franca, Flávio Rocha, confirma a visita de Anhaia Mello e sua equipe de assistentes, a fim de realizar os estudos técnicos para a elaboração do plano diretor. Antes mesmo de ir a Franca, Anhaia Mello orientou o prefeito para que organizasse uma Comissão Técnica e uma Comissão Consultiva, de acordo com a metodologia usual empregada em seus trabalhos de planejamento urbano. A primeira seria constituída por três profissionais da cidade, engenheiros, arquitetos ou da área social, provavelmente Mauro Alves Silveira (engenheiro civil), Luiz do Couto Rosa (arquiteto), e a professora de sociologia do Instituto Estadual de Educação Torquato Caleiro, Vanda Valéria de Faria. A segunda comissão seria integrada por representantes das principais entidades educativas e culturais da cidade, indicadas pelo próprio prefeito. O objetivo do Plano seria evitar o desenvolvimento anárquico da cidade. (CALIL JR. et allii, 2001)

Neste período, como diretor da Faculdade de Arquitetura e Urbanismo da Universidade de São Paulo - FAU USP, Anhaia Melo havia criado o Centro de Pesquisas e Estudos Urbanísticos-CPEU, e articulava contatos com prefeituras de cidades do interior paulista, visando elaborar estudos urbanísticos e planos diretores. (FELDMAN, 2005a)

$\mathrm{O}$ fato, porém, é que as tratativas com Anhaia Melo não evoluíram a contento ${ }^{1} \mathrm{e}$ a idéia da elaboração de um Plano Diretor somente seria retomada, desta vez para valer, no primeiro governo de Hélio Palermo.

Em outubro de 1963, Franca elege como sucessor do prefeito Flávio Rocha (PTB) o vereador, professor primário, economista e industrial calçadista Hélio Palermo (PSP), que derrotou Granduque José, o candidato da situação, por 9.880 a 8.196 votos, diferença não muito elevada. O país vivia então um período de grande agitação e radicalização política, que iria desembocar no golpe militar de 1964 e que mergulharia o país na ditadura.

A cidade de Franca, então próxima aos 50 mil habitantes na zona urbana, passava por um momento de transição em sua história: a industrialização e a urbanização brasileira, aceleradas no período de governo de Juscelino Kubitscheck, sob a égide do desenvolvimentismo, traziam para a cidade a real possibilidade de ampliar e consolidar definitivamente sua base industrial, que desde os anos 1920 já se configurava majoritariamente coureiro-calçadista, indústria manufatureira com intensiva utilização de mão de obra.

Na sua prestação de contas, durante a cerimônia de transmissão do cargo de prefeito, Flávio Rocha lamentou o fato de que, apesar de ter enviado ao Rio de Janeiro dois técnicos da Prefeitura para fazer um curso no Instituto Brasileiro de Administração Municipal - IBAM, com o objetivo de modernizar a administração municipal, o projeto de lei de reforma administrativa da Prefeitura elaborado pelos técnicos como resultado da capacitação feita no IBAM, havia ficado paralisado durante três anos na Câmara pela oposição. Assim que vitorioso Hélio Palermo, o projeto havia sido rapidamente

\footnotetext{
${ }^{1}$ Mauro Alves Silveira é engenheiro civil aposentado e não autorizou gravar entrevista. Porém, relatou informalmente que não prosperou a idéia do Plano, houve apenas uma reunião com Anhaia em Ribeirão Preto que não teve conseqüências. Na época, ele atuava como diretor do Serviço de Água e Esgoto de Franca - SAEF, na gestão de Flávio Rocha.
} 
aprovado, pois considerado importante pelo novo prefeito ${ }^{2}$.

A lei 1204, aprovada no final de dezembro de 1963, estabelecia uma nova estrutura para os órgãos administrativos da Prefeitura, constituindo inclusive, em seu artigo 2, um Conselho de Planejamento presidido pelo Prefeito Municipal e constituído dos seguintes membros:

"- dois vereadores,

- Diretor do Departamento de Viação e Obras Públicas,

- Diretor do Departamento de Planejamento e Urbanismo,

- um representante do Rotary Clube,

- um representante da Associação Rural de Franca,

- um representante da Associação Comércio e Indústria de Franca,

- um representante do Lions Clube,

- um representante dos sindicatos de classe de Franca

- delegado do Conselho Regional de Engenharia e Arquitetura."

No artigo 3, estabelecia-se a competência do Conselho,

"opinar sobre os planos componentes do Plano Diretor, sugerir medidas de planejamento a serem estudadas pelo Departamento de Planejamento e Urbanismo, propor critérios de prioridade para execução dos planos elaborados e conhecer, em grau de recursos, das decisões proferidas pelo diretor do Departamento de Planejamento e Urbanismo em matéria de zoneamento, controle e loteamentos e aplicação do Código de Obras."

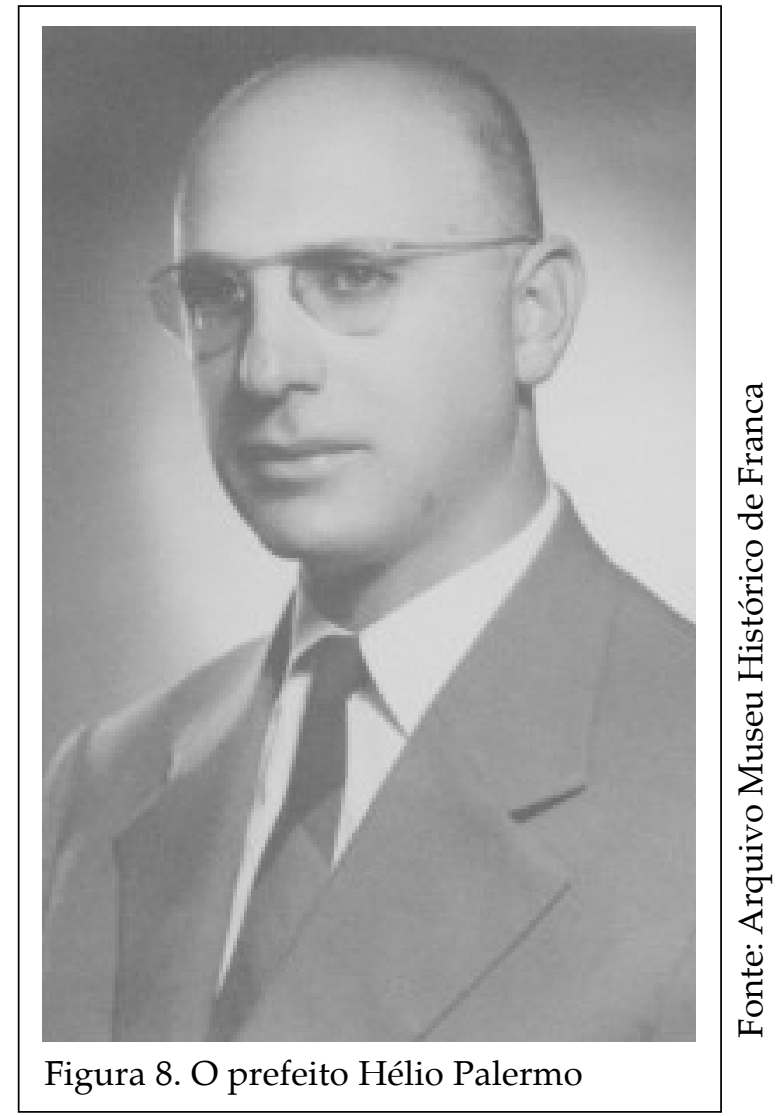

${ }^{2}$ COMÉRCIO DA FRANCA, $1^{\circ}$ de Janeiro de 1964, p.2. 
Também no final de 1963 a Câmara Municipal havia aprovado lei n. 1188, de 9 de dezembro, que previa, no seu artigo primeiro,

\begin{abstract}
"a realização de um trabalho de pesquisa e análise de natureza sócioeconômico, com dimensionamento de necessidades e possibilidades e fixaçãpo de diretrizes para programação das atividades de governo, indicando a necessidade de elaborar programas e projetos das diversas áreas do município para compor o orçamento municipal",
\end{abstract}

demonstrando que já havia uma preocupação com a organização de suas atividades e o planejamento das ações do governo local, sinalizando uma vontade dos administradores e uma necessidade que ia além de mera exigência legal da época. A lei previa inclusive recursos no orçamento do ano vindouro, no seu artigo sexto.

O novo prefeito, na posse, afirmava pretender resolver o que considerava serem os principais problemas da cidade: sua infra-estrutura, incluindo água, esgoto e pavimentação, construção de uma nova sede da Prefeitura e de uma maior assistência aos bairros. Ainda no mês de janeiro, Hélio Palermo detalhou em entrevista ao jornal Comércio da Franca um pouco mais seu plano de trabalho: em relação aos departamentos da Prefeitura, Hélio destacou que

\begin{abstract}
"foram criados mais cinco departamentos pela lei da reforma administrativa, Finanças (ainda sem titular), Jurídico (dr. Walter Anawate), Administração (dr. A. Barboza Filho), Viação e Obras Públicas (eng. Maurício Costa França) e Planejamento e Urbanismo (eng. Luiz do Couto Rosa). Disse o prefeito que a criação destes órgãos auxiliares é velho sonho da administração municipal. Pretendia atacar com urgência os principais problemas do município", destacando dentre eles o de água e esgoto, a construção do novo Paço municipal, prédios para as faculdades de Direito e Ciências Econômicas, término das obras da Escola Industrial, arborização da cidade, construção de novas praças, pavimentação da cidade e construção de mais três grupos escolares (na Vila Raycos, Cubatão e Capelinha). A construção de um novo hotel para a cidade será enfrentado. Mediante a consecução de financiamento estadual"3.
\end{abstract}

Esta última ação vinha especialmente no sentido de atender uma reivindicação do setor calçadista, de melhorar as condições de hospedagem de agentes importadores, comerciantes e compradores que se deslocavam até a cidade para negociar calçados, que então se iniciava ${ }^{4}$.

Em nenhum momento da entrevista, Palermo aprofundou outras questões sociais e sequer tocou na necessidade de um Plano Diretor para a cidade. Porém, deixou expressa uma visão do prefeito segundo a qual havia necessidade de modernizar a administração pública municipal e a infra-estrutura urbana, para que a prefeitura

\footnotetext{
${ }^{3}$ COMÉRCIO DA FRANCA, 21 de janeiro de 1964, p. 8.

${ }^{4}$ Reclamações sobre a falta de um hotel adequado para receber importadores de calçados serão recorrentes na imprensa local, ver edições do COMÉRCIO DA FRANCA de 15 de maio e de 11 de setembro de 1964.
} 
pudesse fazer frente ao crescimento da cidade e à crítica situação de emergência decorrente das constantes faltas de água em diversas regiões da cidade. A criação do Departamento de Planejamento e Urbanismo, certamente, se inseria nesta visão do prefeito, de organizar-se internamente e quanto aos problemas que sua administração teria que enfrentar.

O início da gestão de Palermo é marcado por embates e acusações entre ele e o ex-prefeito, que havia sido eleito vereador (invertendo-se a equação do mandato anterior), rescaldo do confronto eleitoral, principalmente em torno da questão do fornecimento insuficiente de água, realizado por uma autarquia municipal, o Serviço Autônomo de Água e Esgotos de Franca - SAEF. Flávio Rocha critica a lentidão das ações do novo prefeito para resolver a questão da falta de água, que era objeto de muitas críticas pela população, afirmando que Palermo tinha que entender o problema sob o seu aspecto social. Palermo retruca dizendo que havia encontrado a Prefeitura sucateada, com o almoxarifado vazio, máquinas e caminhões quebrados ${ }^{5}$.

Na verdade, a disputa política entre o prefeito e o ex-prefeito apenas desnuda o fato que o crescimento da população e forma como se dava a expansão da cidade não estavam sendo acompanhados no mesmo ritmo pela produção de infra-estrutura urbana e serviços públicos, como o abastecimento de água, do esgotamento sanitário, além de pavimentação e outros equipamentos urbanos. Os recursos disponíveis e a estrutura do poder público municipal não davam conta de acompanhar o ritmo do crescimento da demanda, traduzido no problema das constantes faltas d'água na cidade ${ }^{6}$.

Para a indústria local, no entanto, o momento era propício para o crescimento. De um lado, pela primeira vez na história da cidade, elege-se um prefeito intimamente ligado à indústria calçadista, pois Palermo vinha exercendo as funções de diretor de uma empresa de sua família desde 1948, a Companhia de Calçados Palermo, uma das maiores e mais tradicionais indústrias calçadistas da cidade naquela época. Além disso, Palermo, que havia se formado em Economia em 1954, tornando-se leitor assíduo de Celso Furtado, era observador atento e privilegiado das mudanças em curso da economia brasileira, enquanto vereador e dirigente de indústria.

Desde o governo de João Goulart, os industriais francanos já participavam de articulações políticas e empresariais para ampliar o mercado para seus produtos, seja através do mercado interno, seja através da tentativa de exportar calçados, através de gestões junto aos diversos níveis de governo, como se verifica pela imprensa:

\footnotetext{
"seguiu ontem para a Guanabara o sr. Hugo Bettarelo, presidente do Sindicato da Indústria Calçadista de Franca, a fim de participar de reunião do Grupo Executivo da Indústria de Calçados, recentemente criado por ato do Presidente da República. A reunião tem por finalidade estudar o lançamento de calçados tipo popular, para homens, mulheres e crianças". ${ }^{7}$
}

\footnotetext{
${ }^{5}$ O debate entre Flávio Rocha e Hélio Palermo aparece nas edições do COMÉRCIO DA FRANCA de 21 de janeiro e de 14 de março de 1964.

${ }^{6}$ No COMÉRCIO DA FRANCA, de 6 de fevereiro de 1964, p.3, há reclamações contundentes sobre a falta d'água na cidade.

${ }^{7}$ COMÉRCIO DA FRANCA, 28 de fevereiro de 1964, p.8.
} 
Durante todo o governo de Hélio Palermo há uma intensa participação dos empresários calçadistas francanos no sentido de melhorar as condições da produção industrial: eles se posicionam contrariamente à medida proposta pelo prefeito Hélio Palermo de elevar as alíquotas do Imposto sobre Profissões e Indústrias, assim como reclamam da burocracia estatal para exportação ${ }^{8}$, que estava em seus primórdios.

Alinhado historicamente com o governador Adhemar de Barros, após o golpe militar e com a edição do AI -2 em 1965, ato institucional que acabou com os partidos políticos então existentes, Palermo optou por se filiar à Aliança Renovadora Nacional ARENA, o partido que daria sustentação ao regime militar. O líder da oposição na Câmara, o médico José Lancha Filho, filiou-se ao Movimento Democrático Brasileiro - MDB. O fato é que naquele conturbado período da vida política brasileira, o Ato Complementar 37 prorrogou os mandatos dos prefeitos e vereadores (que se encerrariam em 1967) até 31 de janeiro de 1969, ampliando o tempo do governo de Palermo para cinco anos, o que sem dúvida deu-lhe condições para concluir e efetivar uma maior parte de seus projetos.

Havia indícios bastante fortes e consistentes que Palermo iria de fato perseguir uma reformulação administrativa interna na estrutura da Prefeitura, indicada pelo seu apoio, já prefeito eleito, da aprovação da lei da reforma administrativa do final de 1963, sua declarada intenção de construir um novo paço municipal, bem como suprir as deficiências de infra-estrutura urbana, que preparariam a cidade para o crescimento, tais como a falta de água e a pavimentação de bairros. Por outro lado, vamos observar mais à frente que parte das propostas físicas para a cidade desenvolvidas por sua administração vão ser consolidadas e incorporadas ao futuro Plano Diretor.

Pode-se dizer também que, além da estruturação e da organização interna da Prefeitura, a idéia geral que conduzia a elaboração do Plano, para o principal dirigente municipal, era basicamente a orientação do crescimento físico, pois havia uma demanda explícita, uma crise de infra-estrutura evidenciada nas constantes faltas d'água, de falta de pavimentação e de equipamentos públicos, como vagas nas escolas.

Nas próprias palavras do prefeito Hélio Palermo em entrevista, isto fica explícito:

"Quando fomos prefeitos na outra gestão, anterior a esta, encontramos
a cidade com graves problemas: problemas de ordem técnica, de ordem
administrativa, de fixação da população, de abertura de bairros...enfim,
uma verdadeira colcha de retalhos, e a cidade crescendo, esparramando-
se pelos morros, sem qualquer planificação, trazendo problemas
tremendos para o Município. Então tínhamos que partir, primeiro, para
uma estruturação dos serviços aqui dentro e, depois, para a elaboração
de um Plano Diretor, sem o que a cidade estaria praticamente
estrangulada. Contratamos uma firma de São Paulo, especializada.
Durante um ano e meio ela mandou seus técnicos para cá, trabalhando
dentro da Prefeitura, nas condições da Prefeitura...e da cidade...e eles
foram assim, paulatinamente, estabelecendo o Plano Diretor...A
abertura dessas vias expressas, tudo isso foi feito com a colaboração
dos técnicos dessa firma, durante a elaboração do Plano Diretor".
(AZEVEDO, 1976:140)

${ }^{8}$ COMÉRCIO DA FRANCA, de 21 de novembro de 1964, p. 8 


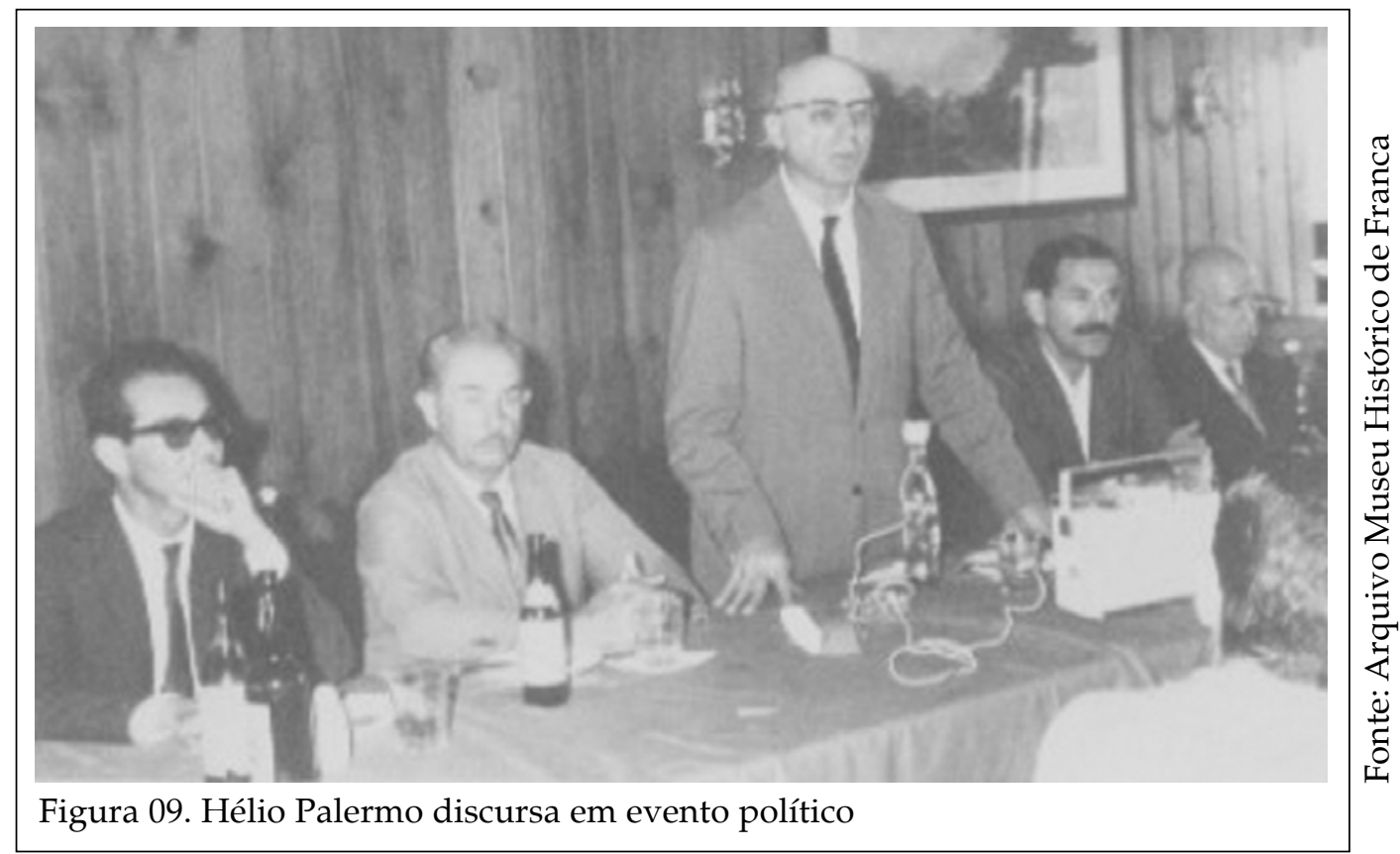

Embora a Lei Orgânica dos Municípios do Estado de São Paulo de 1967 tenha estabelecido como competência municipal a elaboração de seu Plano Diretor, a oportunidade de consolidar estas propostas num Plano Diretor para Franca, porém, vem mesmo do incentivo do governo federal ao processo de planejamento dos municípios, a partir da criação do Serviço Federal de Habitação e Urbanismo SERFHAU, embora houvesse uma latente e difusa percepção da importância do planejamento para os governantes locais em suas declarações públicas à imprensa quanto aos problemas de infra-estrutura enfrentados pela cidade.

Ou seja, a idéia de um Plano Diretor que orientasse o crescimento da cidade, de forma planejada, se coadunava com a perspectiva de utilizar um instrumento "racional" para enfrentar a crítica situação da infra-estrutura local.

O Plano Diretor de Franca foi financiado, inicialmente, com recursos oriundos do Fundo de Financiamento de Planos de Desenvolvimento Local Integrado - FIPLAN, cuja autorização legislativa para a obtenção de empréstimo junto ao SERFHAU foi dada pela lei municipal $n^{\circ} .1 .521$, de 14 de agosto de 1967, quando a prefeitura foi autorizada a contratar, "com empresa especializada de reconhecida idoneidade técnica, a elaboração do Plano de Desenvolvimento Integrado de Franca". A mesma lei estabeleceu um limite para o financiamento, de até NCr\$150.000,00 (cento e cinqüenta mil cruzeiros novos) ${ }^{9}$, que seria garantido por cotas do Fundo de Participação dos Municípios - FPM, que é uma transferência constitucional da União aos municípios, composto de recursos do Imposto de Renda e do Imposto sobre Produtos Industrializados, distribuídos proporcionalmente ao número de habitantes dos municípios.

Posteriormente, em 1968, a lei municipal 1.639, de 12 de agosto, autorizou o Executivo a dar um imóvel do patrimônio municipal como garantia do financiamento

${ }^{9}$ Em valores atualizados, corresponderia a R \$ 201.000,00, de acordo com a Tabela de Atualização Monetária do Tribunal de Justiça de S.P. 
negociado com o SERFHAU, à conta do FIPLAN e do BNH. O Fundo, criado pelo decreto n. 59.917, de 30 de dezembro de 1966, constituía uma conta vinculada, cujos recursos seriam aplicados exclusivamente no financiamento a municípios para a elaboração dos seus planos de desenvolvimento local integrado. Outro aspecto importante é o fato do município já ter formalmente constituído um organismo de planejamento, provavelmente um dos motivos que tornou possível a obtenção do financiamento.

Embora não tenhamos localizado qualquer documento, como o termo de referência ou o contrato relativo ao Plano Diretor de Franca, sabe-se que a contratada, o GPI - Grupo de Planejamento Integrado, que era uma empresa de consultoria sediada em São Paulo, havia sido constituída para atender a demanda criada pelas próprias exigências daquele organismo federal, e desenvolvia uma política de oferecer seus serviços aos municípios, utilizando para isso a sua condição de cadastrada no SERFHAU, a possibilidade de obter o financiamento daquele organismo federal para realizar os serviços e a qualidade de seus trabalhos realizados para as prefeituras de Ourinhos e Mogi-Guaçu. É provável até que o contrato inicial tenha sido feito com a PLANORG, pois os funcionários da prefeitura tinham lembrança desta empresa e não do GPI, até mesmo porque o GPI foi constituído formalmente apenas no final de 1967.

Porém, se não foi possível encontrar um termo de referência, é possível observar alguns aspectos específicos do processo de planejamento desenvolvido pelo GPI, bem como as técnicas utilizadas no próprio trabalho desenvolvido para Franca. Uma mostra significativa desta técnica pode ser observada no roteiro de trabalho do documento intitulado Planejamento Integrado na Região de Franca, pelo próprio GPI e empresas que a compuseram, ECPLAN, PLANORG e o escritório do arquiteto Heitor Ferreira de Souza, e que serviria de base para a sua contratação pelas demais prefeituras da região de Franca.

O documento apresenta motivos para o planejamento municipal, as vantagens de um planejamento integrado (evitar planos isolados, setoriais, concebidos dentro de uma visão imediatista, que evitaria rápida obsolescência de equipamentos públicos pela ausência de uma visão de conjunto dos problemas locais e as relações entre eles, propondo-se soluções peculiares e harmônicas, que trouxessem desenvolvimento ao município) e a legislação sobre o planejamento municipal, considerando a Lei Orgânica dos Municípios de São Paulo (Lei 9.842, de 19 de setembro de 1967) que exigia, em seu artigo 79, a elaboração de um Plano Diretor de Desenvolvimento Integrado, sem o qual nenhum auxílio financeiro ou empréstimo poderia ser concedido pelo Estado ao Município, a partir de três anos da vigência da lei. Embora posteriormente esta exigência nunca tenha se concretizado, o argumento à época podia ser utilizado como uma ameaça velada ao município, que poderia perder acesso às fontes de recursos, totalmente centralizados na União.

É importante detalhar a proposta de trabalho apresentada pela empresa por que, a partir do seu escopo, podemos verificar o nível de aprofundamento que os trabalhos do Plano Diretor Integrado se propunham, coordenados pelo GPI, e em que medida se desdobraram em ações concretas sobre a administração municipal e sobre o espaço urbano local. 
O relatório propõe um Planejamento Integrado da Região de Franca, seja através da elaboração de Planos para cada um dos municípios da região, seja através de um plano comum a todos. O relatório afirma que

\begin{abstract}
"sobretudo na região de Franca, o desenvolvimento de certos municípios depende fundamentalmente da solução de certos problemas regionais; um caso bem específico é o do sistema viário regional, que, sendo deficiente, dificulta um maior intercâmbio entre as sedes municipais, principalmente aquelas que estão situadas a leste e a oeste do Planalto de Franca." (GRUPO DE PLANEJAMENTO INTEGRADO, [196-:10)
\end{abstract}

Após estas considerações, o estudo aponta as fontes de financiamento existentes, em especial aquelas disponibilizadas pelo SERFHAU, como o FIPLAN, que poderiam ser utilizadas pelas Prefeituras para a elaboração do Plano, acrescentando a competência técnica da empresa para a sua realização.

A partir destes elementos, o trabalho transforma-se no escopo de uma proposta, detalhando suas etapas. A primeira delas seria uma pesquisa, com os seguintes objetivos:

a) revelar os fatores dinâmicos e frenadores do desenvolvimento;

b) dimensionar as necessidades relativas ao desenvolvimento econômico, social, físico e institucional;

c) identificar os recursos materiais e humanos, bem como as formas de controle possíveis de mobilizar dentro e fora dos municípios.

A pesquisa seria feita mediante o levantamento de dados disponíveis em fontes primárias e secundárias que seriam posteriormente analisados (diagnóstico) e projetados (prognóstico), permitindo definir o quadro atual e futuro a planejar (GRUPO DE PLANEJAMENTO INTEGRADO [196-]).

As etapas posteriores do Plano Diretor de Desenvolvimento Integrado dos Municípios incluiriam uma fase dedicada ao planejamento físico:

- "mapeamento da situação, onde seriam feitas as plantas básicas das cidades, com curvas de nível, referência cadastral e plantas com a distribuição dos principais equipamentos urbanos;

- política de desenvolvimento físico, contendo os objetivos e meios da política a ser adotada nos próximos 20 anos, com vistas ao crescimento físico harmônico da cidade e áreas adjacentes, mormente no que se refere ao sistema viário urbano, uso do solo, densidade de ocupação, paisagismo, distribuição dos equipamentos urbanos, urbanização de terrenos, etc.

- Lei do Plano Diretor Físico, que visa orientar e controlar o crescimento da cidade, definindo as áreas urbanas e de expansão urbana, as relações entre áreas construídas e áreas livres, entre as edificações e seus lotes e logradouros adjacentes, as normas para o sistema viário, a distribuição das atividades urbanas, etc. 
- Código de Edificações e Instalações, que visa orientar e controlar as características intrínsecas das edificações na área urbana, e o Códigos de Posturas, que visa garantir o uso coletivo do espaço e dos equipamentos urbanos em condições de higiene, segurança e bem-estar". (GRUPO DE PLANEJAMENTO INTEGRADO, [196-]:18)

O Planejamento Institucional seria outra etapa do trabalho, dedicado à reorganização do sistema administrativo e financeiro da Prefeitura, como forma de garantir a concretização das medidas propostas no planejamento físico e sócioeconômico. A proposta incluiu, além da indicação das medidas, a sua efetiva implantação, composto das seguintes ações:

- Reorganização administrativa da Prefeitura, incluindo uma Lei de Organização do Sistema Administrativo e respectivo organograma, um regimento interno da Prefeitura, Lei de Organização do Quadro de Pessoal, Estatuto dos Funcionários Municipais, Racionalização dos Serviços Internos, incluindo normas de serviço, implantação dos serviços e treinamento do pessoal;

- Reorganização do sistema fiscal, incluindo o Código Tributário e Lei de Preços, o regulamento do Código Tributário e da Lei de Preços, a racionalização da máquina financeira, através da implantação de normas de serviços e treinamento de pessoal e a organização do cadastro fiscal;

- Regulamentação dos serviços públicos urbanos, onde seria priorizada a organização do cadastro fiscal imobiliário, através do estabelecimento de um sistema cadastral, o levantamento de campo de todas as unidades imobiliárias, edificadas ou não, situadas na área urbana, o desenho das quadras, a avaliação dos imóveis, a organização dos fichários do cadastro, a elaboração do manual de operação do cadastro e a orientação nos primeiros lançamentos. Além destes aspectos, também seria elaboradas as regulamentações de serviços existentes, como do mercado, matadouro, cemitério, limpeza urbana, abastecimento de água e outros similares.

Uma outra etapa seria aquela do Planejamento Sócio-econômico, incluindo uma Política de Desenvolvimento, que definiria os objetivos a médio e longo prazo, com as diretrizes básicas para o incremento das atividades econômicas, como agricultura, indústria, comércio, transportes e aquelas relativas à educação, recreação, saúde, assistência social, habitação, etc.

A última etapa seria dedicada ao Orçamento Plurianual de Investimentos, que seria elaborado para o triênio 1969-1971, enquanto expressão financeira das obras a serem executadas pela administração municipal, considerando apenas aquelas que implicassem em despesas de capital, agrupadas em programas e projetos setoriais, quantificadas e justificadas.

O relatório apresenta ainda minutas de lei e de um protocolo a ser celebrado 
entre os prefeitos da região de Franca para a elaboração conjunta de Planos de Desenvolvimento Integrado, que não prosperaram, pois apenas a Prefeitura de Franca, que já desenvolvia os trabalhos com o GPI, deu seqüência às ações planejadas.

A descrição das atividades propostas pelo GPI para um conjunto de ações coletivas e integradas dos governos locais da região, antes mesmo da finalização e aprovação do Plano Diretor Físico de Franca, propicia uma visão de conjunto das atividades de planejamento institucional que de fato, como veremos, foram desenvolvidas pela empresa junto à Prefeitura de Franca, incluindo-se uma reforma administrativa, que incluiu toda uma modificação na estrutura e no organograma da Prefeitura, na criação de novas leis (principalmente de caráter urbanístico), de normas internas, organização e métodos para procedimentos administrativos, a total reformulação e constituição de um cadastro técnico imobiliário para fins de planejamento urbano e de cobrança dos impostos municipais, em especial o IPTU. Ou seja, aquilo que o documento propunha, foi desenvolvido pelo GPI ao longo de praticamente cinco anos (19671971) de trabalhos de consultoria e assessoria à administração municipal de Franca.

Os depoimentos dos técnicos da Prefeitura e do GPI ${ }^{10}$ apontam na direção que a elaboração do trabalho foi feita com pequena participação dos técnicos locais e, de forma direta e pública, praticamente nenhuma da própria sociedade francana, que tomou conhecimento do Plano numa única apresentação pública, no final do primeiro governo de Hélio Palermo, em 1969.

Isto poderia dar razão, em parte, à crítica geral que os Planos do período foram elaborados de forma tecnocrática, sem maior participação da sociedade local. Porém, pode-se argumentar também que, naquele período, o processo de participação da sociedade na gestão pública se dava com contatos diretos entre o prefeito, vereadores e lideranças sociais, como dirigentes de entidades representativas e outros setores. $\mathrm{Ou}$ seja, o fato de não haver canais institucionais específicos na administração local para o debate político não significa que não havia ou que não ocorressem pressões de setores organizados sobre a administração municipal. Ocorre que a interlocução ou a mediação política podia se dar de forma direta e informal, até mesmo pelas dimensões da cidade à época, sendo possível encontrar o prefeito, secretários e os vereadores nas ruas ou em eventos públicos ${ }^{11}$. Talvez por isso o próprio Conselho Consultivo do Plano Diretor nunca tenha sido de fato implantado, nem qualquer comissão permanente do plano.

Contudo, ao mesmo tempo, verificaremos que os principais problemas da cidade colocados pelos dois prefeitos do período em que o Plano foi elaborado, Palermo e Lancha Filho, e das questões locais levantadas pela imprensa (modernização administrativa, falta de infra-estrutura urbana, desenvolvimento da indústria calçadista) vão estar contemplados nos trabalhos do Plano.

Podemos dizer que, se os planos diretores do período do SERFHAU estavam descolados da realidade, "fora dos interesses da classe dominante", apresentando-se como uma espécie de superplanos, "peças da mais pura tecnocracia", o caso de Franca

\footnotetext{
${ }^{10}$ Informações obtidas em entrevistas concedidas ao autor por Heitor Ferreira de Souza e Carlos Walter Aumond (GPI) e Weber Drauzio David e Marco Aurélio Résio (Prefeitura). Apenas Maurício Cadaval (GPI) achou considerável a participação local.

${ }^{11}$ Adolescente, eu encontrava Hélio Palermo todos os domingos em jogos de futebol da Francana, onde ele se sentava nas numeradas do estádio, sendo pessoa de fácil acesso. O mesmo se dava com Flávio Rocha.
} 
caminha em direção oposta, pois há um setor local que vai estar presente todo o tempo: o setor empresarial calçadista utiliza-se do Plano Diretor para definir seus interesses sobre a cidade e sua expansão, embora isto não transpareça oficialmente.

Em outras palavras, este "conjunto de compromissos", colocado pela oportunidade do plano, era a prioridade dos políticos locais e de seu empresariado industrial, cuja principal caixa de ressonância era a imprensa, visando defender seus interesses: a possibilidade de expansão da indústria por todo o território da cidade, a oferta de lotes para a mão de obra intensiva, o sistema viário moderno, o distrito industrial, a expansão da exportação de calçados, etc.

Uma outra questão importante que se coloca é como foi possível a própria continuidade do processo de elaboração, aprovação e implementação do Plano, já que Lancha Filho, que havia sido vereador e líder da oposição no primeiro mandato do arenista Palermo (1964-1969), sucedeu-o eleito em 1968 pelo MDB. Palermo voltaria a governar a cidade entre 1973 e 1977. Ora, não seria possível a continuidade do processo não fosse esse "conjunto de compromissos", de interesse tanto do empresariado calçadista quanto dos próprios governantes.

Palermo chega até a afirmar que o Plano não teve continuidade:

"infelizmente, quando recebi o Plano, faltavam apenas três meses para o término do meu governo, e ainda assim ficaram de fazer a implantação, aqui, da famosa reforma administrativa dentro da Prefeitura. Esta reforma não foi concluída durante o meu governo, mas no governo do meu sucessor...os meus sucessores (sic), os meus engenheiros, continuaram no outro governo, de maneira que não houve solução de continuidade. Não houve uma boa compreensão por parte do meu sucessor, porque ele recebeu aquela peça, um trabalho formidável, primeiro de reforma administrativa, depois de implantação de serviços, por exemplo, a elaboração do cadastro físico, do cadastro fiscal e outros cadastros, todos eles organizados com base no trabalho dessa Comissão...agora infelizmente as obras...porque, quando se faz um Plano Diretor, se estabelece uma programação de recursos, em primeiro lugar, de necessidades, enfim a viabilidade de execução, e o meu sucessor, talvez por desconhecer essas particularidades, não obedeceu aquele Plano Diretor". (AZEVEDO, 1976:141)

Lancha Filho afirma outra coisa:

“O Hélio não viveu (o Plano Diretor), eu vivi, porque quando eles fizeram a montagem do Plano para entregar, porque era uma imposição do Governo da Revolução, que todas as cidades tivessem Plano Diretor, senão não participariam da distribuição de verbas, do Fundo de Participação dos Municípios. E o Hélio contratou a firma e ela trabalhou, só que ele nunca se interessou, tanto é que no dia que eles foram apresentar a conclusão, que foi lá na Faculdade, que na época era de Filosofia, hoje é a Unesp, e lá eles fizeram uma apresentação pela manhã, a mesa tava composta, o Hélio se levantou e disse que estava de viagem para São Paulo e disse para conversarem com o Lancha, que foi o prefeito eleito, o sucessor, é ele que vai viver o Plano Diretor. Convivi demais 
com esse povo, que era gente muito capacitada, aliás, foi um grande acerto do Hélio a escolha desta firma". ${ }^{12}$

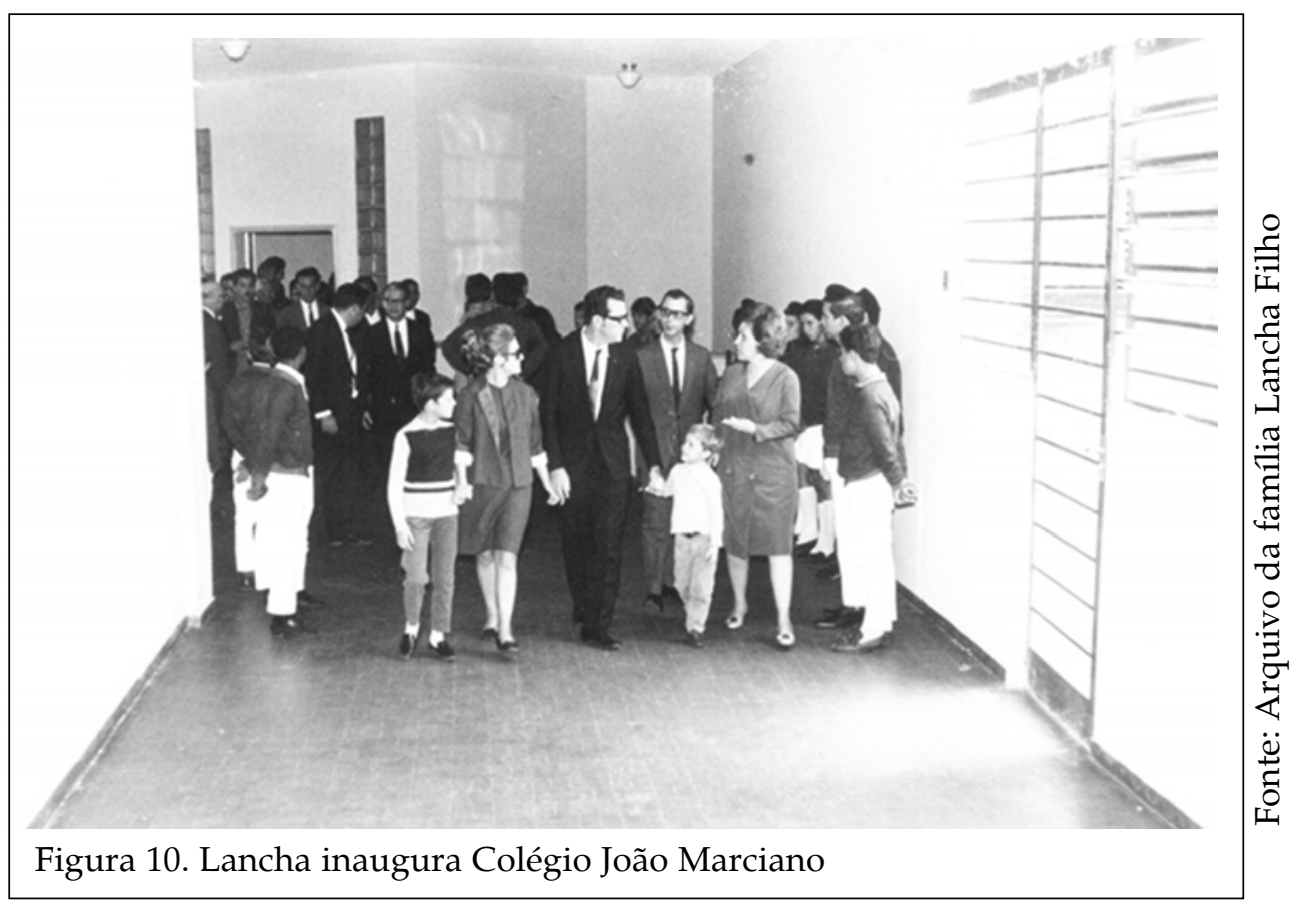

Já para o ex-prefeito Ary Balieiro, a questão se apresenta de outra forma:

“O Plano veio por exigência. No governo do Hélio, ou do Lancha, veio uma verba para fazer o canal dos Bagres, ali embaixo, e uma verba para a captação de água, acho que eram uns 500 milhões, era uma nota preta. Só que o governo tinha condicionado qualquer tipo de ajuda à existência do Plano Diretor. Aí o Lancha acelerou. Não foi mal-feito, acho que o projeto tinha coisas boas. Mas só que não foi seguido, aquele espírito que o Plano Diretor deve ter, de orientação para o crescimento da cidade, de ocupação da cidade, de urbanização e reurbanização da cidade, isso o pessoal não ligou, não, ligou mais para o Código de Obras, que praticamente também não tinha muita restrição, acho que valeu muito esse Plano Diretor, foi um dos primeiros no estado de São Paulo". ${ }^{13}$

Apesar das falas de Palermo e Lancha Filho serem contraditórias, verifica-se que há um elemento que pode ser considerado integrador entre as duas administrações: os assessores de Palermo e Lancha Filho nas questões relativas ao meio físico e urbano, são os mesmos, o engenheiro civil Weber Drauzio David e o arquiteto Luiz do Couto Rosa, ambos envolvidos diretamente na feitura do Plano Diretor. Além deles, diversos outros técnicos municipais de carreira, que posteriormente assumiram funções

\footnotetext{
${ }^{12}$ Entrevista ao autor, em 06/01/2005.

${ }^{13}$ Entrevista ao autor, em 19/01/2005. Na época dos governos Lancha e Palermo, Ary Balieiro estava na iniciativa privada, o que pode explicar sua interpretação sobre o Plano ser exigência de um financiamento para fazer o canal dos Bagres. As obras de canalização financiadas pelo DNOCS foram realizadas no governo Lancha Filho.

O mesmo não se pode afirmar do fato que as obras que Balieiro propôs e executou, em sua maioria, estavam previstas no Plano Diretor, cuja influência ele procura minimizar na entrevista.
} 
importantes, inclusive como secretários nas áreas de finanças e administração, como José Suavinho e Marco Aurélio Résio, vivenciaram todo o processo, trabalharam e foram treinados pelos técnicos do GPI, dominando as técnicas e as propostas elaboradas durante os trabalhos do Plano ${ }^{14}$.

Na verdade, a reforma administrativa, a implantação do organismo municipal de planejamento, do orçamento-programa, de organização e métodos, do novo cadastro físico municipal, todos estes elementos foram implementados, parte num governo, parte noutro. Ou seja, embora fossem de partidos diferentes, sua leitura e diagnóstico da realidade local, apoiados também na visão dos técnicos que os auxiliaram, não tinham grandes diferenças no entendimento dos problemas locais e de como enfrentá-los.

Ao longo do primeiro governo de Hélio Palermo são construídos o primeiro trecho da avenida marginal ao córrego do Cubatão (avenida Ismael Alonso y Alonso, entre avenidas Champagnat e Major Nicácio) e iniciada a canalização do córrego dos Bagres, visando implantar a avenida Robert Kennedy (atual Hélio Palermo), obras que já eram objetivo de Hélio antes mesmo do Plano, mas que são incorporadas a ele.

No final de seu governo, em 1969, como relatou o próprio Lancha Filho, Palermo fez uma espécie de prestação de contas dos trabalhos do Plano, cumprindo provavelmente uma exigência do SERFHAU, que enviou representantes ao evento.

O seminário foi realizado no dia 26 de janeiro de 1969 (Lancha Filho tomaria posse dias depois, em 31 de janeiro), na Faculdade de Filosofia de Franca:

\begin{abstract}
"Conclave dos mais importantes (em termos de interesse da comunidade) foi o que realizou segunda-feira última, às 10 horas, numa sala da Faculdade de Filosofia, sob a denominação - algo pomposa de Primeiro Seminário de Avaliação do Plano de Desenvolvimento Integrado do Município de Franca. A presença do atual prefeito, dr. Hélio Palermo, e do prefeito eleito, dr. José Lancha Filho, e o comparecimento de vereadores da atual e futura legislatura deram maior responsabilidade à reunião, uma vez que o planejamento municipal não poderá sofrer solução de continuidade, nem deverá ficar à mercê de vaidades partidárias ou questiúnculas pessoais. (...) Abertos os trabalhos pelo atual prefeito, fizeram-se ouvir o arquiteto Mário A. Melo, diretor do Grupo de Planejamento Integrado (GPI), que deu algumas explicações, e o sociólogo dr. Maurício Cadaval, que fez uma síntese geral do plano e de seu mecanismo. A problemática econômica, social e cultural do município foi analisada pelo economista Roberto Perosa, em seus aspectos agrícola, industrial e educacional. A problemática física foi explanada, através da projeção de diapositivos e ilustrada com fotografias e plantas da cidade, pelo arquiteto Jairo José Farias, que focalizou muito bem importantes problemas urbanos, como os da rarefação da malha urbana, boçorocas, circulação e o distrito industrial. Finalmente, o sr. Otávio Gonçalves, técnico em administração, falou sobre a problemática administrativa" ${ }^{15}$.
\end{abstract}

\footnotetext{
${ }^{14}$ Em entrevista ao autor realizada em 21/01/2005, Suavinho afirma: "foi devagar se implantando uma nova estrutura administrativa, as divisões, os setores, secretarias. O GPI mandava as minutas, decreto, portaria, eu preparava tudo para ter a assinatura do prefeito, transformava isso em ato administrativo".

${ }^{15}$ COMÉRCIO DA FRANCA, 30 de Janeiro de 1969, p.4
} 


\section{Comércio da Franca}

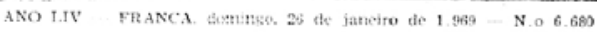

Amarihà, 1.0 S€minário de Avaliaçào do Plano Diretor de Desenvolvimento Integrado de Franca

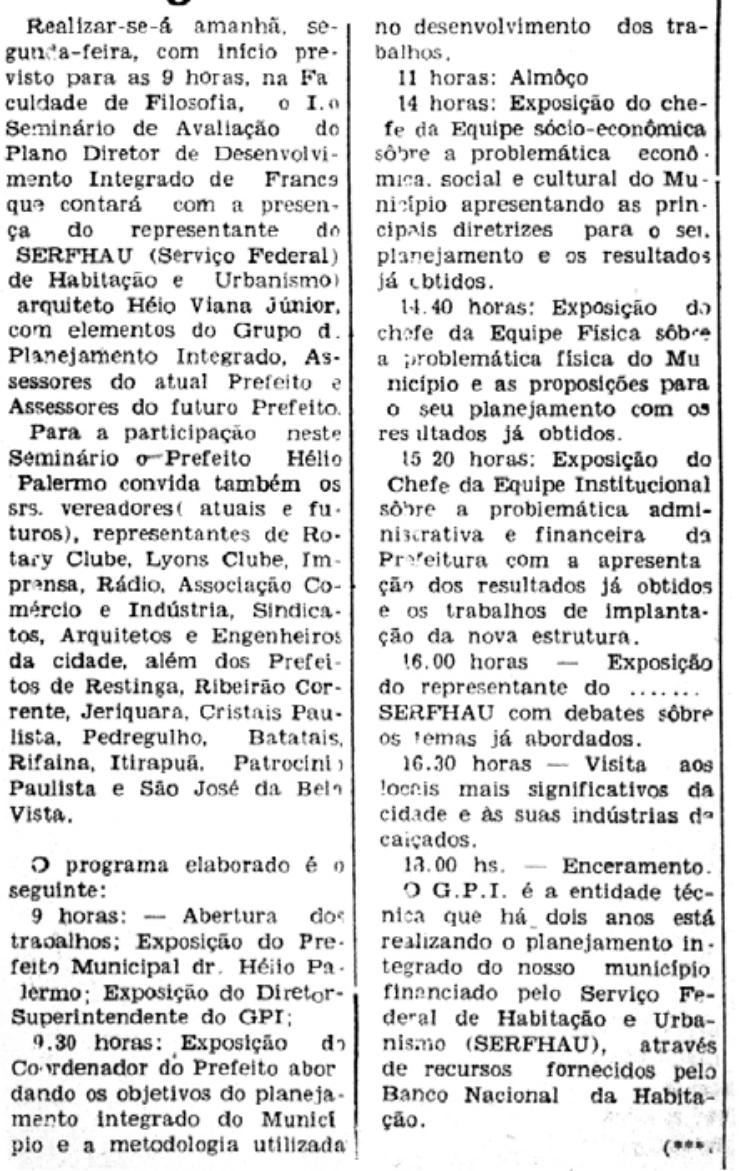

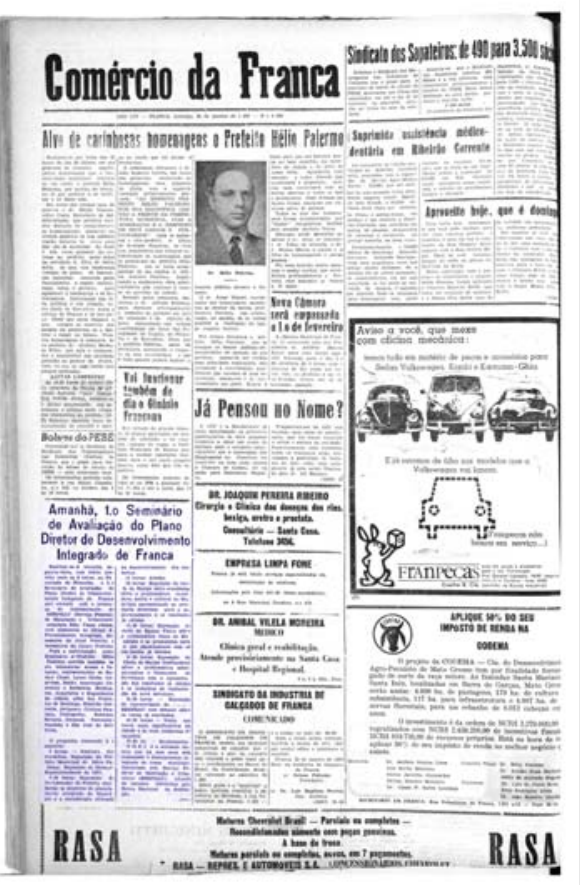

Figura 11. Convite para o Seminário de Avaliação do Plano Diretor

Embora o texto jornalístico traga algumas imprecisões (Mario Mello não era arquiteto, era administrador público, responsável pela área no GPI), percebe-se duas ausências importantes no evento: de Arruda Câmara (já estávamos sob a vigência do AI-5, ele seria preso logo depois) e também de Heitor Ferreira de Souza, que aparece como o responsável pelas questões físicas do Plano nos mapas (ele provavelmente já havia entrado em choque com seus sócios à época, como afirmou em seu depoimento ao autor). É o arquiteto Jairo José Farias que vai apresentá-las publicamente. 


\title{
A APROVAÇÃO DA LEI DO PLANO DIRETOR
}

Apesar do Plano Diretor Físico estar pronto desde esta época, o Executivo Municipal, liderado por Lancha Filho, enviou o projeto de lei à Câmara, sem qualquer outro debate prévio, efetivamente, apenas no final de novembro de 1971, quando havia uma velada ameaça do governo estadual de suspender repasse de recursos para os municípios que não tivessem um Plano Diretor, coisa que na verdade nunca se concretizou.

O regime militar vivia então seu período de maior repressão política, já sob a égide do AI-5, recrudescendo o autoritarismo do regime. O ofício formal de encaminhamento do projeto de lei à Câmara pelo prefeito José Lancha Filho informa que o Plano, com seus cinco volumes, tratava-se de trabalho altamente técnico, e que o GPI e a equipe técnica da prefeitura estavam à disposição da Câmara para participar dos debates sobre o mesmo. O parecer da Comissão de Justiça, assinado pelos vereadores José Mércuri e José Finardi Garcia, afirma explicitamente que o projeto havia sido enviado à Câmara visando atender o dispositivo da Lei Orgânica dos Municípios, em que nenhum auxílio financeiro ou empréstimo seria concedido pelo Estado ao Município que não tivesse um Plano Diretor. O mesmo parecer afirma também que

\begin{abstract}
"tendo em vista que a área escolhida ou indicado no Plano para o Distrito Industrial não mais corresponde à época atual, visto que o plano foi elaborado há algum tempo, entende que deverá ser escolhido e indicado um novo local. Isto tendo em vista o desenvolvimento da indústria e a expansão urbana" 16 .
\end{abstract}

Com isso, fica clara a intenção dos vereadores em preservar as iniciativas e interesses específicos do setor industrial.

Objeto de duas votações, o projeto de lei foi aprovado definitivamente na sessão extraordinária da Câmara Municipal do dia 27 de dezembro de 1971, sendo promulgado pelo prefeito em 6 de janeiro de 1972.

A Câmara Municipal de Franca, nesta legislatura, era constituída por quinze vereadores, sendo catorze da ARENA e apenas um do MDB. O vereador Fábio Celso de Jesus Liporoni (advogado), era o presidente da mesa da $40^{\circ}$ sessão ordinária, realizada no dia 20 de dezembro de 1971, que aprovou em primeira votação o Plano Diretor, composta ainda por Sebastião Campanaro (advogado), Walter Peres Chimello (advogado), José Granzotte (servidor público) e Severino Edson Salles Meirelles (produtor rural). Votaram ainda Antônio Marcos Kaluf (contador eadministrador de empresas), Ciriaco Garcia Lopes (professor), Francisco Villaron (professor), Heitor de Lima (produtor rural), José Mércuri (taxista), Milton José Baldochi (bancário, o único do MDB). Não compareceram, sem fornecer justificativa, os vereadores Daladier Correa Neves (comerciante) e Domenico Pugliesi (professor) e, com justificativa, José Finardi Garcia (comerciante) e José Sanches Neto (professor) ${ }^{17}$.

Embora nesta legislatura não houvesse nenhum vereador ligado diretamente ao empresariado industrial, havia alguns pontos de ligação com o setor: José Finardi Garcia

\footnotetext{
${ }^{16}$ Extraído do parecer da Comissão de Justiça da Câmara Municipal de Franca, projeto de lei n. 75, de novembro de 1971, p. 2

17 Extraído da Ata da sessão ordinária da Câmara Municipal de Franca de 20 de dezembro de 1971.
} 
era comerciante de produtos químicos para calçados e havia trabalhado na indústria de Hélio Palermo. Sebastião Campanaro e Marcos Kaluf possuíam escritórios de advocacia e de contabilidade que prestavam serviços a indústrias locais. Severino Meireles, Heitor de Lima e Fábio Liporoni eram ligados a famílias tradicionais e abastadas da cidade, possuidoras de terras na região ou próximas à zona urbana.

A ausência de debates mais expressivos e de qualquer tipo de participação da sociedade nas discussões sobre o Plano Diretor e sobre a nova legislação urbanística, decorrentes do momento ditatorial sob o qual vivia o país, foi transferida também para a Câmara Municipal, que aos 429 artigos propostos na nova lei, apresentou apenas sete emendas, que foram aprovadas e incorporadas ao projeto.

As alterações efetuadas pela Câmara, através das emendas ao projeto original do Executivo, atendiam quase exclusivamente o setor industrial: foram deixadas fora da lei aprovada do Plano a parte relacionada à localização do Distrito Industrial, que seria objeto de lei específica, liberava a construção, reforma e ampliação de estabelecimentos industriais em qualquer local do perímetro urbano, enquanto não fosse implantado o Distrito Industrial, e estabelecia um prazo máximo de dois anos para a implantação do próprio Distrito Industrial, permitindo que as fábricas continuassem a ser construídas em qualquer local da cidade, enquanto a municipalidade não o implantasse de fato. Outras duas emendas trataram da composição do Conselho Consultivo do Plano Diretor, que deveria ter treze membros, sendo cinco da Prefeitura, dois da Câmara Municipal e seis da sociedade civil, incluindo-se um representante da Associação do Comércio e da Indústria de Franca. Ressalte-se que este Conselho embora previsto na lei, jamais chegou a ser instituído.

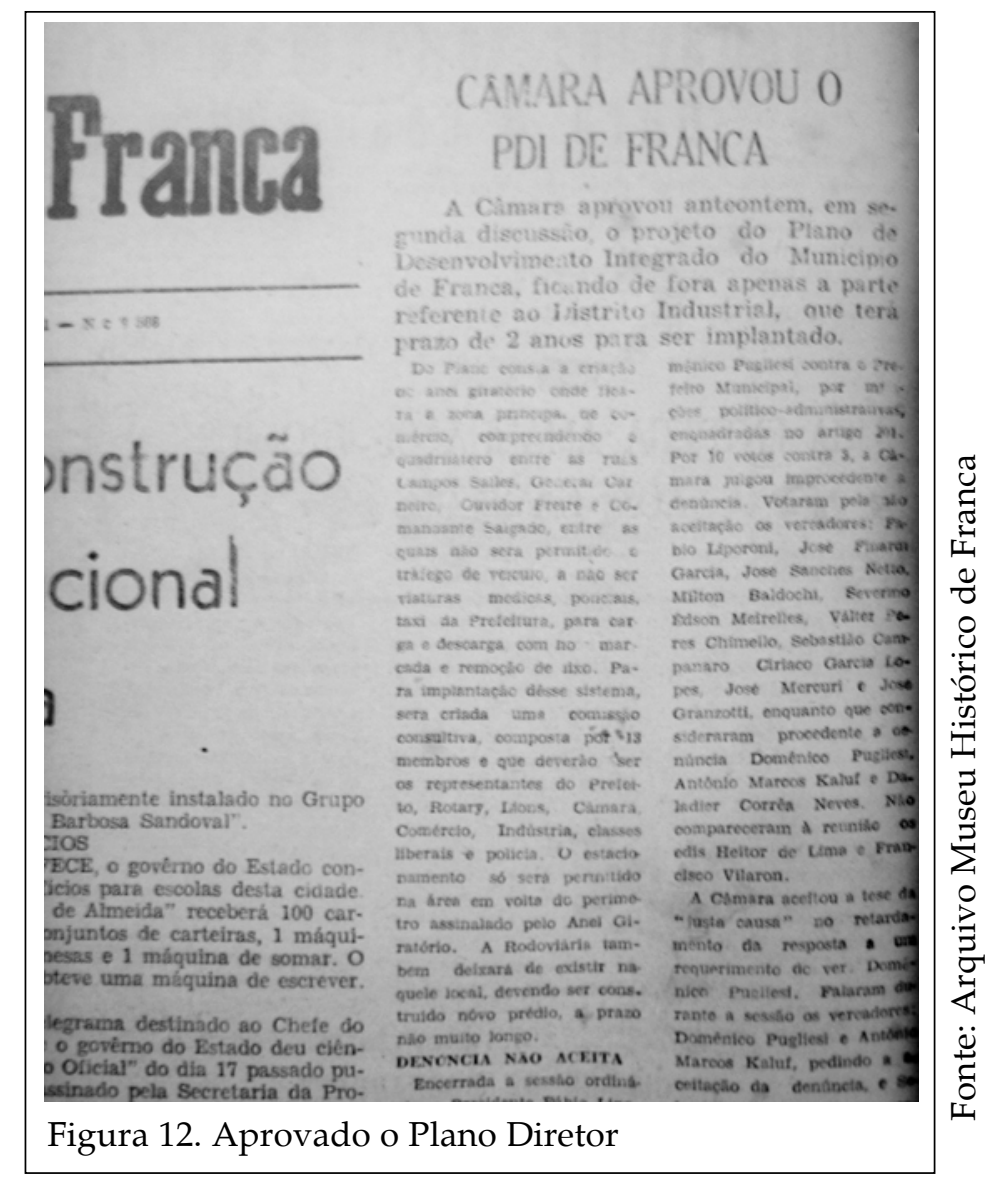


Durante o restante do governo de Lancha Filho, adquiriu-se a área para implantar o Distrito Industrial, continuaram-se as obras iniciadas na gestão anterior, de retificação, canalização de córregos e pavimentação de suas avenidas marginais e inaugurada a área de lazer do Vale dos Bagres. Além destas obras da gestão anterior, dentre outros aspectos do Plano, foi construído o centro de feiras e exposições para abrigar a Francal, de grande interesse dos industriais calçadistas.

Em 1972, o candidato apoiado por Lancha Filho perdeu as eleições para Hélio, que retornou à Prefeitura em janeiro de 1973. É importante ressaltar que Lancha Filho havia abandonado o PMDB no meio do seu mandato, após ser pressionado pelo governo estadual, filiando-se à ARENA, o mesmo partido de Hélio, embora os dois continuassem adversários.

Dentre as obras previstas no Plano, Hélio deu seqüência às avenidas marginais aos córregos do Cubatão e dos Bagres, bem como à avenida Major Nicácio. Outra obra importante prevista no Plano tem iniciada sua implementação, pois foi iniciada a pedestrianização do centro, primeiro em um quarteirão da rua do Comércio, depois um novo trecho do centro, na rua Marechal Deodoro.

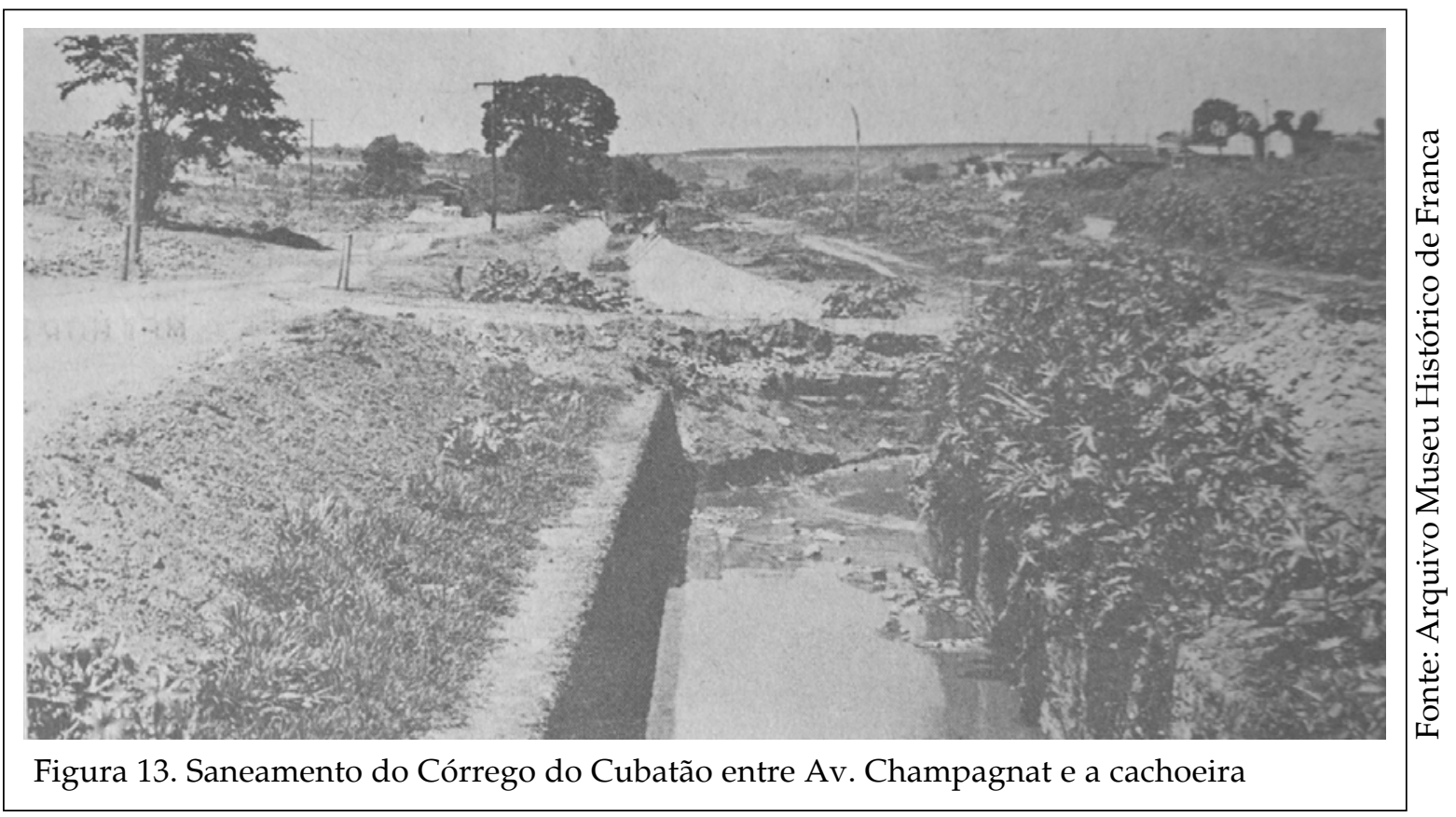

\section{O PLANO DIRETOR NO CENTRO DO DEBATE POLÍTICO}

Em 1974, a tentativa do governo municipal de colocar em prática os dispositivos previstos na Lei do Plano Diretor relativos às normas para edificações nos lotes, como o afastamento e recuos das construções em relação à via pública e outras regras previstas na lei geraram um primeiro embate político e público tendo como temática o Plano Diretor, que envolveu a Câmara, a Prefeitura e a recém-criada Associação dos Engenheiros e Arquitetos de Franca. 


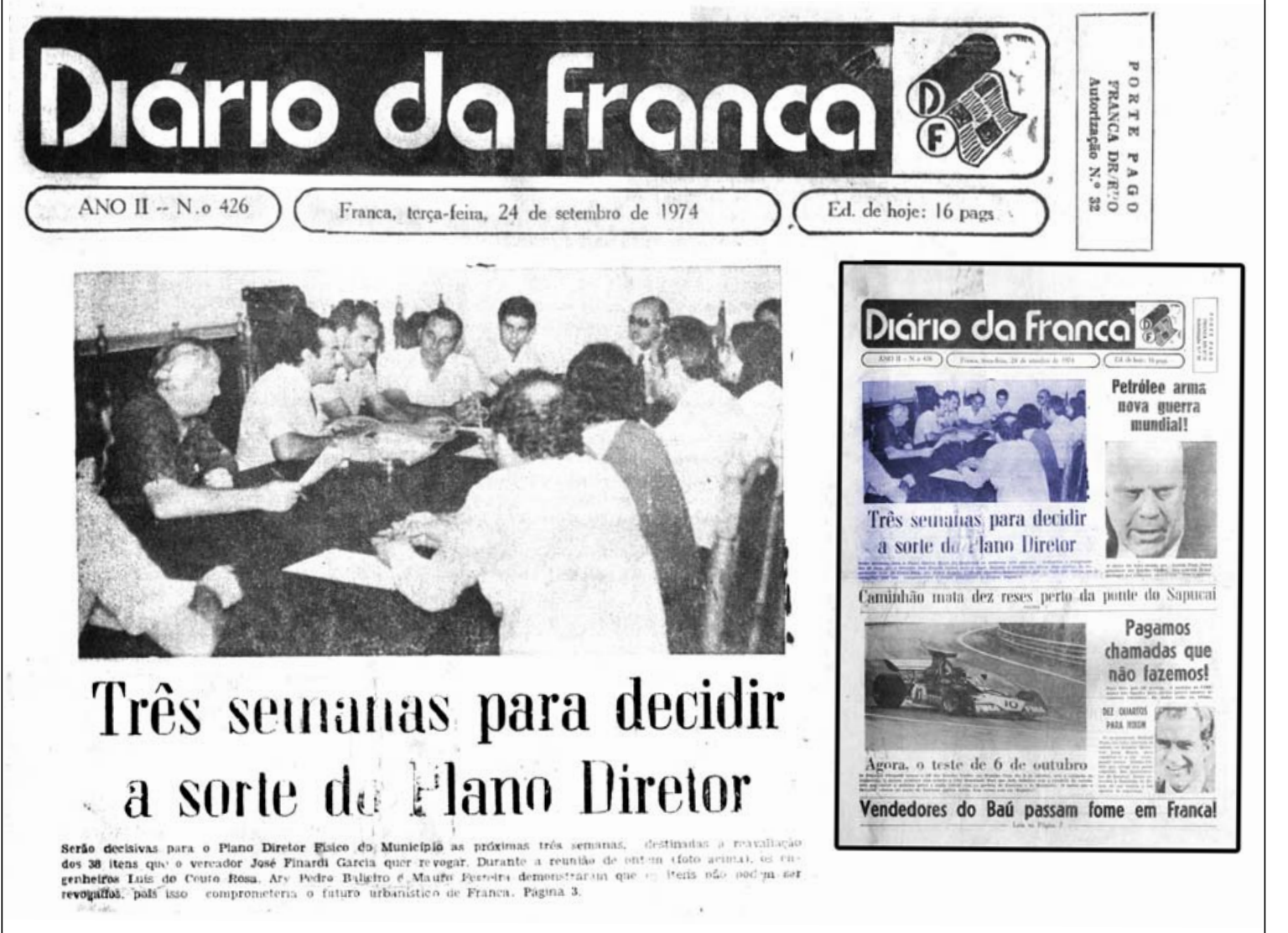

Figura 14. Debates sobre o Plano Diretor vão para manchetes.

O vereador José Finardi Garcia (Arena) ${ }^{18}$ apresentou um projeto de lei que revogava integralmente 38 artigos da lei do Plano Diretor. Sua proposta, no entanto, foi atacada pela Associação dos Engenheiros e Arquitetos e repercutiu na imprensa, levando a modificações negociadas e a uma valorização do Plano pelas autoridades municipais, ao menos no plano discursivo. Os principais aspectos da lei a serem alterados referiamse à exigência de lotes mínimos com $300 \mathrm{~m} 2$ de área e aos afastamentos de 5 metros das vias públicas, em lotes com 20, 25 metros de profundidade e de 1,50 metros das laterais.

Segundo Finardi,

"isto era uma forma de pressionar o Chefe do Executivo, pois há mais de 2 anos vem solicitando ao prefeito a constituição de uma comissão para estudar e reformar certos aspectos do Plano Diretor. Como o chefe do Executivo nunca constituiu a comissão solicitada, preferiu agir sozinho e propôs a revogação pura e simples, como forma de pressão"19.

\footnotetext{
${ }^{18}$ Na época, a Câmara Municipal de Franca possuía 15 vereadores, 14 deles eram da Arena, apenas um do MDB.

${ }^{19}$ DIÁRIO DA FRANCA, 24 de setembro de 1974, p. 3
} 
O projeto de Finardi Garcia, de n. 50/74, foi objeto de um relatório de análise de uma comissão de estudos sobre o projeto, criada pela Associação dos Engenheiros ${ }^{20}$, após duas reuniões, realizadas em 24 e 27 de setembro de 1974.

A síntese das discussões da Comissão, na reunião do dia 24 foi a seguinte:

"Após debates, chegou-se preliminarmente, às seguintes conclusões: que apesar de muito bem estruturado, o Plano Diretor de Franca, já apresenta falhas devido às distorções já ocorridas no crescimento da cidade, pelo tempo ocorrido entre plano e aplicação efetiva. Deste modo, a situação de fato não está sendo levada em conta no planejamento urbano. Portanto, faz-se necessária a reformulação do P.D., sem que para isto seja necessário revogar qualquer de seus itens, por sinal os mais importantes e justamente os que devem ser mantidos. Deste modo, sugerimos a adição dos seguintes itens: 1) para os loteamentos aprovados anteriormente à data de ... e durante 5 anos a contar desta data, serão exigidos:

a. Para edificações residenciais:

1. recuo mínimo de 3 metros;

2. ocupação máxima de $60 \%$;

3. obediência às leis de ventilação e iluminação.

b. Para edificações industriais:

1. recuo mínimo de 6 metros;

2. área mínima de $1000 \mathrm{~m} 2$.

c. Para as seguintes ruas centrais: ...não é obrigatório o recuo.

O prazo fixado acima visa dar tempo aos proprietários dos terrenos terem tempo hábil para construírem, e ainda, dar tempo ao poder público para que execute o distrito industrial, sem o que, qualquer planejamento não terá perspectiva nenhuma, pois não se poderá efetivar o zoneamento" ${ }^{21}$.

Com o argumento da inexistência do Distrito Industrial, o zoneamento previsto na lei não é implementado, não afetando diretamente o setor produtivo industrial, motivo pelo qual as fábricas de calçados continuam se disseminando por todas as regiões da cidade, principalmente nos novos loteamentos que surgiam, como Jardim Guanabara, Jardim Ângela Rosa e Parque Progresso. (FERREIRA, 1989)

\footnotetext{
${ }^{20}$ A Comissão era formada pelos engenheiros Paulo Vieira França e Mauro Silveira, bem como pelos arquitetos Ary Pedro Balieiro e o autor. Nesta época, recém-formado arquiteto pela FAU Braz Cubas, retornei a Franca para trabalhar, inicialmente como funcionário responsável pelo setor de projetos de arquitetura da empresa Balieiro e Construções Ltda., pertencente ao arquiteto Ary Pedro Balieiro (que posteriormente seria eleito vereador e prefeito da cidade). Foi a partir desta experiência inicial, no âmbito da constituição e da afirmação da Associação dos Engenheiros e Arquitetos de Franca (fundada em 1972) enquanto entidade representativa das categorias profissionais nele abrigadas, que iniciei uma participação política mais efetiva. No segundo semestre daquele ano de 1974, uma propositura na Câmara Municipal mobilizou os profissionais arquitetos da cidade (éramos apenas seis então): o vereador José Finardi Garcia apresentou uma proposta de revogação da Lei do Plano Diretor, contra a qual nos insurgimos, levando o debate para a imprensa, o que motivou a abertura de um diálogo com a Câmara que propiciou algumas modificações na lei, basicamente nalguns aspectos relacionados ao uso e ocupação do solo, como recuos das edificações nos lotes e normas para a aprovação de edículas. A discussão foi bastante acalorada, gerando destaque e cobertura da imprensa, que repercutiu amplamente os debates ocorridos. No fundo, porém, o que se discutia não eram as propostas de ação concreta e investimentos públicos previstos pelo Plano, mas seus aspectos de controle do uso do solo.

${ }^{21}$ Extraído da cópia datilografada do documento, arquivo pessoal do autor.
} 


\section{Engenheiros reprovam mudanças no Plano Diretor}
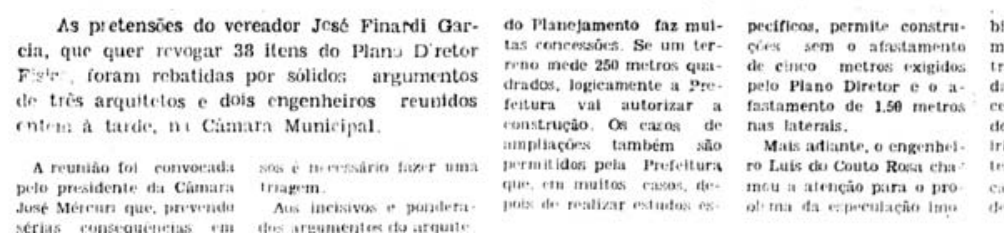

billaria que surgiria fatal-
mente. Esat especulaçẫo

. Esea ispeculaçato por exemplo.

Enèrrando a reuniấo, o cia, que quer rrvogar 39 ilens do Ping F. Toram rebitidas por solide; argurnentos entent à tarde, nt Cimara Municipal.

Figura 15. Técnicos criticam alterações do Plano Diretor

Na verdade, a proposta de Finardi ${ }^{22}$ tinha como objetivo pressionar o prefeito a alterar dispositivos do Plano, voltados ao zoneamento e à ocupação dos lotes e à edificação nos lotes, que atenderia sua clientela política (e de outros vereadores), basicamente visando facilitar a ocupação dos lotes urbanos com duas edificações no mesmo lote, uma construção principal e pequenas edículas nos fundos, principalmente para aluguel. Além disso, a prefeitura não dispunha de uma fiscalização eficiente, que desse conta do surgimento de indústrias de fundo de quintal que surgiam em grande número, sem qualquer processo de legalização e que eram importantes para manter os níveis de emprego e renda da cidade.

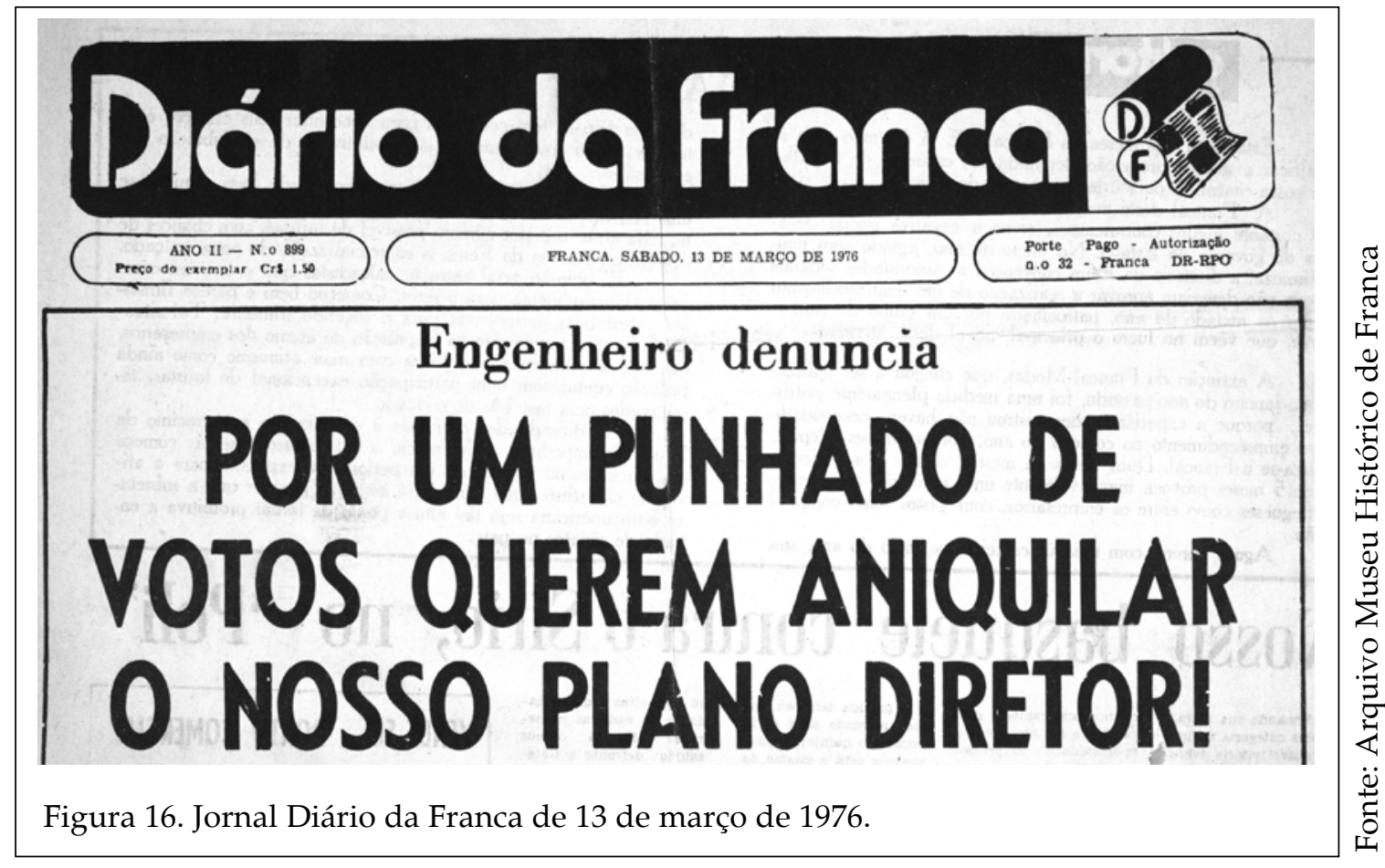

${ }^{22}$ CÂMARA MUNICIPAL DE FRANCA, Projeto de Lei n. 50/1974. 


\begin{tabular}{|c|c|}
\hline 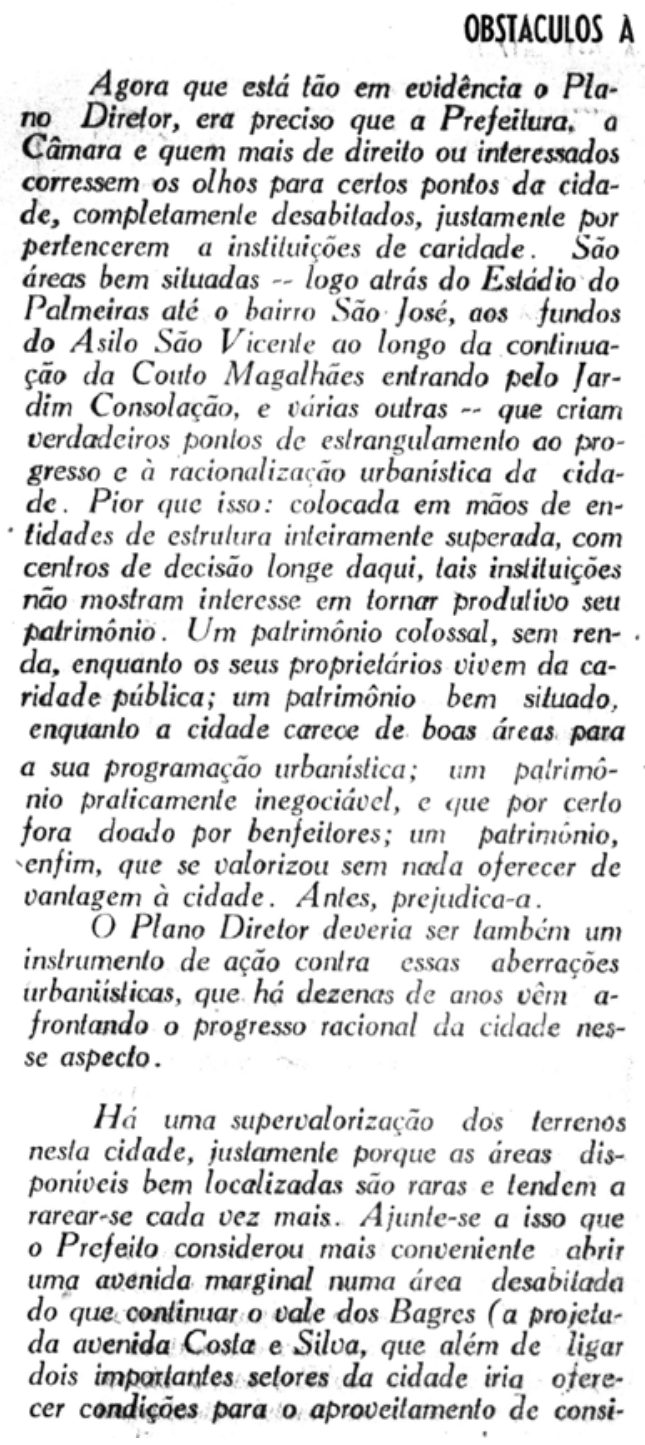 & 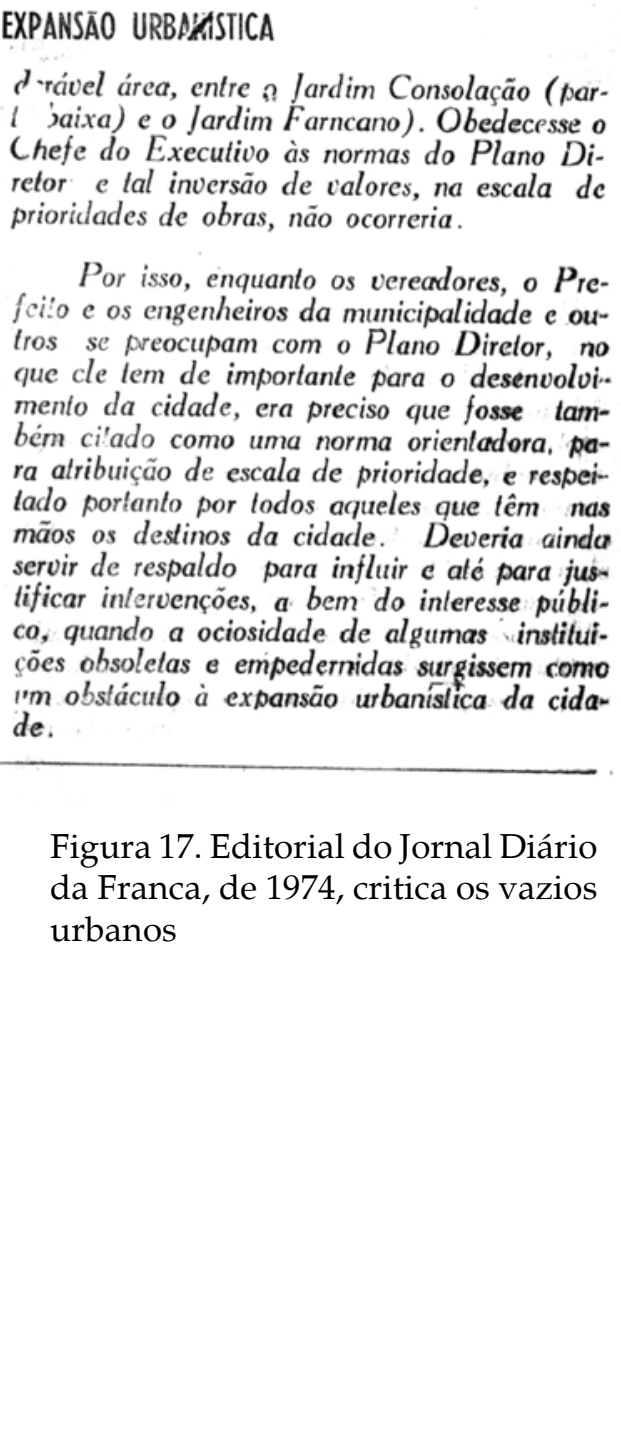 \\
\hline
\end{tabular}

O documento elaborado pela Associação dos Engenheiros serviu para abertura de um diálogo com a Câmara que se transformou numa alteração da lei bem menos radical que a proposta por Finardi, flexibilizando algumas normas e encontrando alternativas no próprio texto da lei, como a permissão para lotes com área de $160 \mathrm{~m} 2$ nos loteamentos considerados populares. No entanto, às vésperas das eleições municipais de 1976, novas e sucessivas alterações de aspectos pontuais, ligados especificamente à implantação das edificações nos lotes foram feitas pela Câmara Municipal. Algumas propostas eram flagrantemente casuísticas, como a que impedia a construção de edifícios com menos que 10 pavimentos, para obrigar a verticalização da praça principal da cidade ${ }^{23}$.

\footnotetext{
${ }^{23}$ Ver artigo "Por uns miseráveis votos, a Câmara quer aniquilar o Plano Diretor", do autor, DIÁRIO DA FRANCA, 13 de março de 1976, p.2.
} 
$\mathrm{Na}$ verdade, os aspectos de controle de uso e ocupação do solo dos lotes foram os que criaram maiores embates políticos, maiores até que os dos loteamentos, pois afetavam direta e conjuntamente interesses dos proprietários de imóveis, do setor imobiliário e de clientela, principalmente dos vereadores, cuja atuação, no contexto de esvaziamento do poder legislativo e da repressão política vigente, retirava-lhes condições de efetuar uma ação realmente fiscalizadora ou propositiva junto ao Executivo, era um Legislativo amordaçado e impedido de atuar como deveria. Ao mesmo tempo, já se acentuavam cobranças explícitas para a implantação do Distrito Industrial ${ }^{24}$.

\section{Carta aherta à administração municipal}

Infelizmente, a administração Hélio $\mathrm{Pa}$ lermo vem se revelando de uma total incapacidade de discernir as prioridades para um desenvolvimento crgânico do município. Com uma Câmara de vereadores tomando decisões sem um minime de bases técnica e uma total inoperância por parte dos técniccs municipais, temos que assistir impotentes à estagnação econômica e urbana da cidade de Franca.

A administração municipal, atuando sem qualquer planejamento e sem qualquer principic básico, executa obras que nem de longe se revelam prioritárias no âmbito do desenvolvimento urbano, mas muito mais como uma es pécie de autc-afirmação do prefeito, como nos casos do Poli-esportivo, do prolongamento da avenida dr. Alonso y Alonso e da ponte que ligará a Francal à cidade. Obras perfeitamente dispensáveis na conjuntura atual, num momento em que a nossa rede de água se mostra incapaz de atender às necessidades, en que grande parte de nossa cilade não tem esgoto nem asfalto, em que a nossa própria industria não tem mais meios fisicos de crescimento, que entrava a nossa ec nomia e por conseguin te toda a cidade.

É hora de lutar pelo Distrito Industrial, de lutar para uma diversificação de nosso parque industrial. É hora de se olhar pelos menos al guns ancs para frente, e implantar o Distrito Industrial, sem o qual a cidade dentro em pouco se tornará inviável, com sua qualidade de vida irremediavelmente em colapso. Hoje, somcs obrigados a conviver com a poluição das água e dar, com a pcluição sonora, que já vem atingindo níveis insuportáveis.

$\Lambda$ ausència do Distrito vem onerando a iniciativa particular francana sobremaneira. Os curtumeiros da cidade vem sendo pressionados pela CETESB para a instalação de filtros $\mathrm{ccm}$ o objetivo de eliminar a poluição das águas, porém com o sistema propcsto, haverá um aumento da poluicão do ar. Ora, a nosso ver, o ploblema poluição não seria resolvide. seria simplesmente protelado: Com a existência do Distrito Industrial, os filtros poderiam ser instalados numa central, com a consequente redução dos custos de instalação e mesmos operacicnais, deixando a iniciativa privada de ser onerada com um investimento supérfluo.

Figura 18. Associação dos Engenheiros e Arquitetos cobra Distrito Industrial para a cidade

A implantação do Distrito Industrial atrairia novas indústrias, pois Franca já é um pólo de atração, só não sendo mais forte seu parque inclustrial pela ausência de infra-estrutura na sua area urbana, já quase que saturada.

Nosso poder público alega falta de ecndicôes para a efetiva implantação do Distrito Industrial, mas para o Poliesportivo (que até agora pelo menos não cumpriu suas finalidades) havia verba da ordem de quase 2 milhões de cruzeiros. A ponte scbre o córrego do Cuba. tão também tem participação financeira d? Prefeitura, que não é pequena. Os pavilhões a a nova entrada "monumental" da Francal também foram construídos $\mathrm{ccm}$ o dinheiro da $\mathrm{Mu}$ nicipalidade. Monumentais foram os gastos inúteis, com prédios que só são usados durante uma semana ao ano. Pode uma cidade pobre como a nossa se dar ao luxo desta capacidade ociosa?

Assim, exigimos da Municipalidade e dos homens que a dirigem, uma definição de prioirdades, baseadics em pareceres técnicos

Qucremos uma politica de ação, não uma pclitica eleitoeira. Como aconteceu com o problemz da água, onde inclusive, nossos jornais noticiaram a reunião do prefeito com as "forças vivas" da cidade para a solução do problema. Só que o Prefeito simplesmente esqueceuse de cenvidar a Associação dos Eengenheiros de Franca, pois ela provavelmente atrapalharia os objetivos demagógicos da reunião.

Não queremos, com este arrázoado, dizer que com o Distrito tudo está resolvido, que o Distrito será a redenção. Mas, que com ele nós teremos dado efetivamente, um largo passo para o futuro, em direção a um desenvolvimento hazmonico e integrado desta cidade.

aa) - Presidente, Vital A. de Paiva Neto, e 1. o Secretáric, Mauro Ferreira, da Associação dos Engenheiros, Arquitetos e Engenheiros Agrônomos da Região de Franca.
${ }^{24}$ Embora eu conhecesse o Plano desde a época de estudante de arquitetura (Luiz do Couto Rosa havia me fornecido um exemplar), foi a partir destes embates sobre o Plano Diretor na Câmara Municipal que passei a ter um conhecimento mais amplo de seu conteúdo e das suas propostas para a cidade. Passei a colaborar assiduamente com a imprensa local, debatendo suas propostas e cobrando das autoridades públicas sua implementação. Em 1975, já exercendo as funções de secretário da Associação dos Engenheiros, elaborei um documento em conjunto com o engenheiro Vital Paiva Neto, intitulado "Carta aberta à administração municipal" (Publicado no DIÁRIO DA FRANCA, 26 de novembro de 1975, p.4), cobrando do prefeito Hélio Palermo a implementação do Distrito Industrial como uma alternativa ao desenvolvimento industrial da cidade, onde afirmava que a construção do Distrito e a diversificação industrial eram componentes essenciais ao futuro da cidade. 
A aplicação de algumas das propostas e diretrizes do Plano, que já vinha se dando mesmo antes de sua transformação em lei, relativas ao sistema viário, ao vale dos Bagres e ao início da pedestrianização do centro se intensificou a partir de 1977, já no governo Maurício Sandoval Ribeiro. Maurício foi eleito por uma sublegenda da Arena, o chamado "Grupo Novo", que se opunha a Hélio Palermo. Sua indicação para o cargo de assessor de planejamento, o economista Fernando Bueno Ribeiro, importou em significativa mudança, pois pela primeira vez exercia o cargo um profissional que não era arquiteto. Na metade da segunda gestão de Hélio Palermo, Couto Rosa havia sido substituído pelo arquiteto Antônio Sérgio Maisano Arantes. Couto Rosa foi deslocado para a direção da Empresa Municipal de Desenvolvimento de Franca - EMDEF, uma empresa pública criada por Palermo em 1975, cujo objetivo principal era realizar obras de infra-estrutura e pavimentação na cidade.

O engenheiro Weber Drauzio David, que havia assessorado Palermo e Lancha Filho no setor de obras, continuou na mesma secretaria ${ }^{25}$. realizando as mesmas tarefas de coordenação e execução de obras públicas, naquela época ainda em boa parte construídas por administração direta.

Sob a coordenação de Bueno Ribeiro, tem início a implementação de aspectos importantes do Plano Diretor Físico, relacionados à expansão da cidade: são desenvolvidos projetos de ampliação do sistema viário, a partir da obrigatoriedade de fornecimento de diretrizes para novos loteamentos, incorporando definitivamente aos projetos o dimensionamento previsto na lei, com avenidas preferenciais de 32,00 metros de largura total mínima ${ }^{26}$, como a Orlando Dompieri (antiga Amélia Antunes Pinheiro), São Vicente, Chafi Facuri, prolongamento da avenida Brasil e outras. Em entrevista, Bueno Ribeiro afirma que enfrentou dificuldades no início,

\footnotetext{
“apanhei muito, né, principalmente em relação à ocupação urbana, você inclusive esteve presente, fomos nós que levantamos a questão de realmente pegar o Plano Diretor e ser instrumento, embora a gente já tivesse feito uma análise do Plano Diretor lá no Instituto de Pesquisas Econômicas - IEPES".27
}

\footnotetext{
${ }^{25}$ Logo após sua posse, em 1977, Bueno Ribeiro convidou-me para exercer, no cargo de arquiteto comissionado, inicialmente, atividades ligadas à aprovação de projetos e de controle de uso e do solo e, posteriormente, em 1978, o engenheiro civil Wilson Luiz Teixeira, para a mesma função, quando fui deslocado para a área de projetos de arquitetura e urbanismo. Foi nesta condição que iniciei polêmicas pela imprensa com a Câmara, visando manter as características principais do Plano Diretor, especialmente em relação ao uso e ocupação do solo, bem como a exigência de cumprimento da lei em relação aos parcelamentos do solo, como áreas verdes e largura das vias. Nesta época, eu já havia deixado o escritório de arquitetura de Ary Balieiro, que havia sido eleito vereador pela Arena, mesmo partido do prefeito eleito, Maurício Sandoval Ribeiro.

${ }^{26}$ Conforme artigo 69 da Lei 2046/72, Lei do Plano Diretor Físico. Posteriormente, desenvolvemos na Assessoria de Planejamento todo um Plano Viário para a expansão urbana, que foi sendo implementado à medida que novos loteamentos eram aprovados. A entrevista de Ary Balieiro concedida ao autor corrobora a existência deste Plano Viário no primeiro governo de Maurício Sandoval Ribeiro, embora seus desenhos não tenham sido localizados.

${ }^{27}$ Entrevista gravada concedida ao autor em 01/02/2005. Bueno Ribeiro havia sido diretor do Instituto de Pesquisas Econômicas - IEPES, da Faculdade de Ciências Econômicas de Franca, autarquia municipal, onde tinha grande contato com a indústria calçadista, desenvolvendo pesquisas sobre a economia local. Diz ainda que cuidou do orçamento programa e de modificações na programação do IPTU, modernizando-o e que, antes de assumir o governo, foram auxiliados por técnicos do Banespa na montagem de um plano de ação para o governo municipal.
} 
Também a exigência de áreas verdes e institucionais passa a obedecer aos limites de $13 \%$ no total da gleba loteada ${ }^{28}$, quando antes se exigia apenas $10 \%$, o mínimo definido pelo Código Sanitário do Estado. Com isso, voçorocas que antes passavam a fazer parte da área cedida ao município como única área verde dos empreendimentos, passaram ao patrimônio público como acréscimo, a exemplo de partes da voçoroca das Maritacas e do Jardim do Líbano.

No entanto, a pressão exercida pela Câmara Municipal sobre aspectos normativos da lei do Plano Diretor Físico permaneceu durante todo o governo de Maurício. Já no início do seu mandato, em junho de 1977, o vereador arenista Victor de Andrade apresentou um conjunto de alterações na lei do Plano, sugerindo adiar as exigências que começavam a ser feitas aos loteamentos para o ano seguinte de 1978, bem como reduzindo exigências técnicas para obras particulares e facilitando o desdobramento de lotes.

\section{Diario da franca \\ Plano Diretor: "projeto do vereador instituirá a promiscuidade urbana"}

Em matéria da última página, o arquiteto Mauro Ferreira, da Assessoria de Planejamento da Prefeitura, refuta as críticas que o vereador Víctor de Andrade (foto) apresentou ao Plano Diretor Físico do Município. O arquiteto diz que 'a parte referente a desmembramentos de terrenos é uma válvula aberta ao especulador imobiliário, pois sob qualquer pretexto, pode-se transformar um lote em vários. $E$ isso é a institucionalização da promiscuidade urbana". Em outra parte da matéria, Mauro Ferreira considera que as mudanças propostas pelo vereador ao Plano Diretor 'se não prejudicam irremediavelmente a parte normativa, pelo menos cria dificuldades enormes na aplicação do referido plano". O arquiteto chega também a afirmar que 0 projeto apresentado pelo vereador 'nos leva a crer que o seu intuito não é apenas modificar a Lei, mas sim levar às últimas conseqüências a sua notória indisposição com o atual assessor'.

Figura 19. Debates sobre o Plano se sucedem

\footnotetext{
${ }^{28}$ Conforme artigo 226 da Lei 2046/72, Lei do Plano Diretor Físico.
} 


\section{Sidnei Rocha: «a cidade está parada por teimosia da Assessoria de Planejamento»}

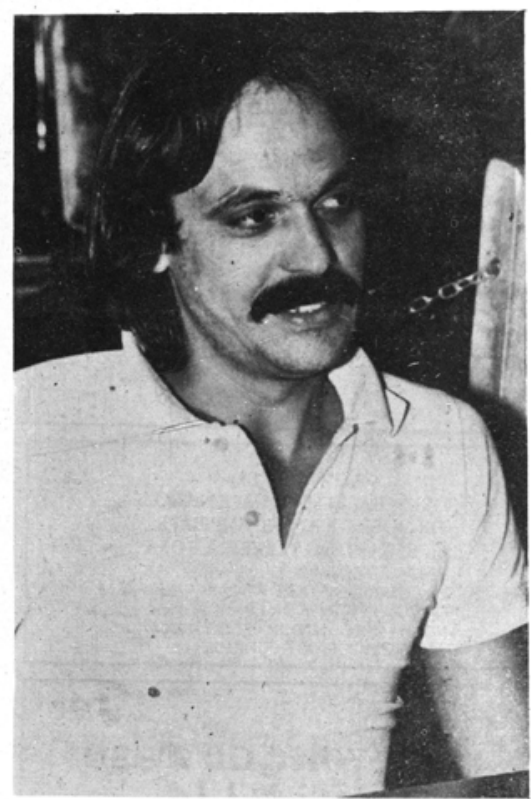

O vereador Sidnei Franco da Rocha refutou as declaraçðes feitas pelo arquiteto Mauro Ferreira a esta folha, da cedição a de 25 último, sob o título 'Projeto do vereador instituirá a promiscuidade urbana ... Disse o edil que leu 'com muita atenção a matéria' e respeita tanto o vereador Victor de Andrade ccmo Mauro Ferreira, mas acha que a cidade está parada, e parada por teimosia da Assessoria de Planejamento da Prefeit
ra'.

ASSESSORIA GANHA TEMPO

A tese que não só Víctor de Andrade levanta sbservou o vereador - é de que nés temos que observou o vereador - é de que nés temos que solucionar os impasses existenités o mais rapidamente de 6 meses. Várias reuniốes foram feitas e não se chegou a conclusão nenhuma. Escre 1-se, ficou t' t itado que a a conclusão nenhuma. Escre 1-se, ficou t' tado que a
Assessoria de Plancjamento enviaria um projeto. Assessoria de Planejamento enviaria um projeto. Quando os vereadores apertam, a Assessoria convoca outra reunião para discutir a musma coisa e, no fim, a
Assessoria está enrolando, ganhando tempo para não resolver os impasses existentes

'Et: pergunto, prossegue Sidnei Rocha: A Assessoria do Planejamento existe para o progresso da cidade, ou para que a cidade fique parada como está e as construç̄es diminuam? As construçōes em Franca, cidade tremendamente carente de moradias, estãu insignificantes. Então, o que precisa haver? Primeiro: nas reunıōes ficaram acertadas muitas modificações. C vereador Víctor de Andrade apenas apresentou-as num projeto seu. E esse projeto, segundo o acordo, deveria ser apresentado pela Assessoria de Planejamento, que não o fez. Só que o vereador apresentou alguma coisa a mais do que es ava convencionado, se bem que nã - "oi discutido tudo"

\section{MAIOR ABERTURA}

'Agora, quando eu lí as críticas do Mauro Ferreira. entendo que tanto a Assessoria como o vereador podem entrar numa briga pessoal. Mas nós não temos que nos preocupar com isso. As modificaçōes sã̃o necessárias porque o Plano Diretor é de aita aplicação numa cidade planejada, como Brasília. Mas Franca está plantada em mais de 150 anos. Então nós temos problemas que o Plano Diretor não soluciona e, se formos segui-lo à risca, a cidade pára"

Sidnei Rocha prossegue suas explanaçōes afirmando que 'o que os vereadores $\mathrm{e} a \mathrm{C}$ amara pleiteian $-\mathrm{e} \mathrm{não}$ só o vereador Víctor de Andrade - é que haja uma abertura maior para que a cidade continue a progredir. Năo acredito em 'promiscuidade urbana' como alega o arquiteto. Inclusive, aquela proposta de 80 por ceete de área construída foi feita na reunião da Câmara, realizada há cerca de 15 dias, e ela não se manifestou, deixando para fazế-lo no jornal'.

\section{NO MESMO ERRO}

Para o vereador, "o arquiteto devia dar sua opinião na Câmara, diante dos vereadores. A verdade é que Assessoria de Planejamento e os vereadores se reúnem. Assessoria de Planejamento e os vereadores se reunem,
estes opinam a Assessoria concorda na hora possivelmente para fazer média, mas depois não resolve possivelmente para fazer media, mas depois náo resolve o problema. E o que acontece? Estamos há um an tentando dinamizar o Plano Diretor $\mathrm{e}$, conseqüentemente.. as construçoes para o progresso da cidade, que em certos aspectos está cerceado pelo plano. Se o Plano está atrapalhando, nôs devemos corrigir o que está errado. O que não podemos é ficar brigando, discutindo, sem chegar a uma soluçăo para os problemas

Dando sequêtncia às suas idéias, Sidnei Rocha apela para que 'a Assessoria de Planejamento não seja tão teimosa assim. E vamos colocar em prática as modificaçðes que são extremamente necessárias, algumas das quais os homens da Assessoria concordam, ou pelo menos concordaram na reunião com os vereadores, que são de extrema urgência. Fora disso fica uma polêmica que não leva a lugar algum. Então nós, que somos na maioria uma equipe nova de vereadores, e Prefeitura, que criticamos tantas as administraçסes pas sadas por polêmicas desnecessárias através das emissora e dos jornais da cidade, estamos exatamente come 'çando a incorrer no mesmo erro, coisa que sou contra'.

'SEM MEDO, CONTINUO A CRITICAR'.

'O que eu acho - disse também Sidnei - é que a Assessoria de Planejamento precisa é de um maio dinamismo, maior boa vontade e deixar de realmente 'botar banca porque eles estão 'botando muita banca' e trabalhando muito pouco"

'Finalizando - arrematou o vereador - digo aos leitores que tenho procurado criticar sem pepreguir a
administração pública. Sou líder do MDB e estou na administraçào pública. Sou lider do MDB́ e estou na Cámara para criticar tudo aqui que está errado. Sei que
os assessores do Prefeito não estão gostando das minhas os assessores do Prefeito não estáo gostando das minhas críticas. O próprio prefeito também não está gostando. cento isto c problema deles e não meu. Na verdade, tem muita coisa errada nessa administração. Só falei a quinta parte daquilo que sei que está errado. O restante a gente vai mostrando à populaçáo com o tempo. Quero dizer que não adianta cara feia, não adiantam ameaça porqle o que está errado nós temos que mostrar. Nós 作 mostrar as falhas. O movimento 'Mário de Andrade', por exempl, eu critiquei e fui muito combatido por isso. Dizia que seria uma piada o movimento Mário de Andrade. Hoje ele é a piada que eu disse, porque vai comecar a querer tapar o sol com a peneira, uma vez que foi criàda a Fundação 'Villa Lobos'. E o movimento 'Mário de Andrade' gastou talvez 600 mil cruzeiros este ano e continua sem estrutura por culpa exclusiva d Prefeitura, através de seu Departamento de Educação e Cultura Entāo as críticas vã̃o continuar, não me afastarei delas, não temo ameaças, não vou me acovardar $c$ se equivocam totalmente aqueles que pensam o contrário. Vou continuar descobrindo que está errade, denunciando e procurando corrigir tais erros, independentemethe do aspecto politico, mas mu mato mascor un progressista 


\section{Mercuri refuta Arquiteto}

"O arquiteto Mauro Ferreira inão devia falar muito sobre Plano Diretor e outros assuntos parecidos, porque foi contra a abertura da rua Angelo Paludetto, quando todos pretendiam da Administração a desapropriação do terreno".

A declaração partiu do vereador José Mercuri que apresentou o recente projeto de lei que intøduziu modificações no Plano Diretor e que teve a assinatura de mais 12 vereadores.

Mercuri disse que o arquiteto Mauro Ferreira " "foi infeliz ao afirmar que a Câmara está a cata de votos com este projeto, porque nenhum vereador teve essa intenção". “Quando a Câmara resolveu apreciar este projeto, foi porque havias problemas de dificil solução que estavam trazendo sérios embaraçós para quem deseja construir - em Franca".

"Nenhum vereador pensou em obter votos. E, de minha parte, posso dizer que nenhum vereador seria ingênuo de pensar que, com um projeto como este ou outro qualquer, teria sua eleição garantida",.

O vereador afirmou, por fim, “que está representando os anseios de um povo que está cansado de ir clamar 'ao Prefeito e aos seus assessores por soluções".

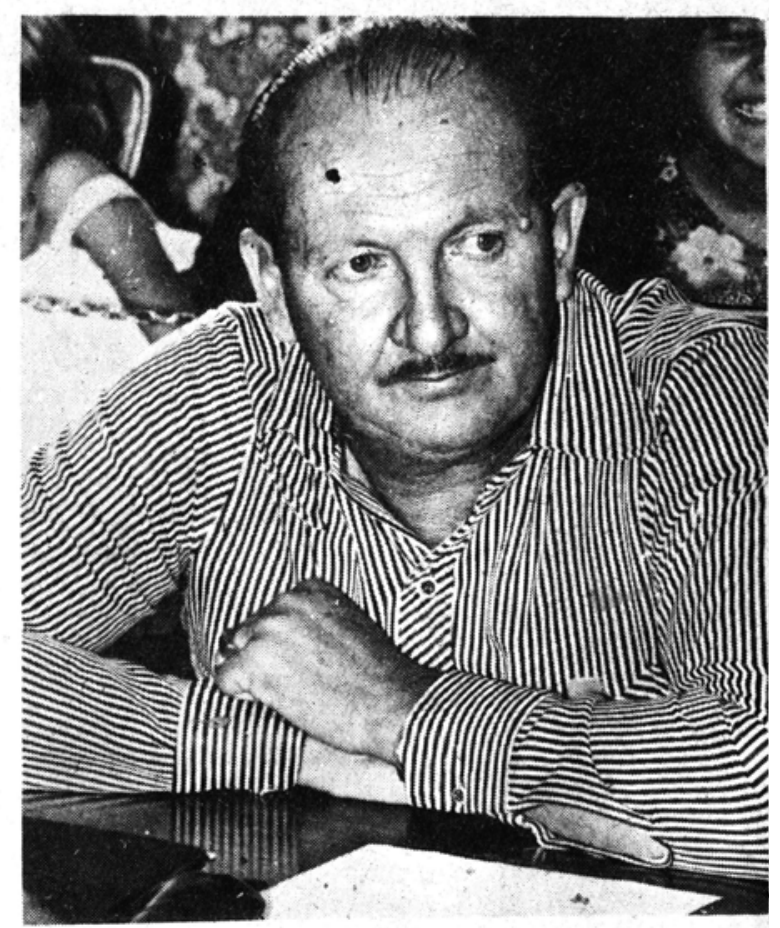

Figura 21

Os debates se sucedem, com a intervenção direta no debate do líder da oposição e da bancada do MDB na Câmara, vereador Sidnei Rocha, posicionando-se favoravelmente às alterações, ao passo que a equipe técnica da assessoria de Planejamento passa a rebater as críticas da Câmara ${ }^{29}$. O prefeito decide bancar o ponto de vista da assessoria apenas no que se refere à implantação de edifícios altos, que exigiam grandes recuos, cedendo nos demais à pressão da Câmara, que aprova mais uma vez alterações na lei. Em seguida, em meados de 1978, nova alteração da lei do Plano reduz os recuos para edificações que, embora questionada na Justiça ${ }^{30}$, através de uma ação popular ${ }^{31}$ contra a Câmara pela aprovação daquela lei, termina com o óbvio resultado favorável à Câmara Municipal.

\footnotetext{
${ }^{29}$ Ver artigos "Plano Diretor: projeto do vereador instituirá a promiscuidade urbana", do autor, DIÁRIO DA FRANCA de 25 de novembro de 1977, p. 8, e entrevista de Sidnei Rocha, "A cidade está parada por teimosia da Assessoria de Planejamento", DIÁRIO DA FRANCA de 30 de novembro de 1977, p.3.

${ }^{30}$ Em conjunto com outros profissionais da Associação de Engenheiros e Arquitetos, embora fossemos servidores da administração municipal, eu e o engenheiro Wilson Teixeira propusemos uma ação popular contra a Câmara Municipal, alegando que a redução dos recuos mínimos poderiam gerar problemas de salubridade nas edificações, além de ferir a legislação sanitária estadual. Fomos derrotados em todas as instâncias a que recorremos.

${ }^{31}$ Ver DIÁRIO DA FRANCA de 16 de junho de 1978, p. 12.
} 


\section{Decisão judicial mantêm Plano Diretor de Franca}

Sentenças proferida nos autos de Ação Popular que os arquitetos Mauro Ferreira e outros propuseram contra a Prefeitura e a Câmara de Franca manteve o atual Plano Diretor Físico do Município. A pretendida ilegalidade das leis que modificaram o Plano Diretor, bem como o dano ao patrimônio estético nâo encontraram o desejado amparo judicial.

Em sua sentença o dr. Rubens Zumstein, Juiz de Direito da Comarca local, dentre outros considerados, decidiu: "Lesividade: Entrentanto, não ficou demonstrada a lesividade dos atos administrativos ao patrimônio público municipal. E nem a sua ilegalidade, como adiante será acentuado. com a máxima vênia dos autores e do representante do Ministério Público. Bem disseram os co-réus Câmara Municipal e seu Presidente, que a lesividade da coisa pública atacada pelos autores, por prejudicar "e muito" o embelezamento da cidade, que se esforça pelos autores, harmoniosamente"...

"desfigurar as linhas arquitêtonicas e funcionais da cidade" constituem" consepção subjetiva".

Frizaram os co-réus, mais à frente, que Fran-
" assim, atendendo a peculiar interesse o Município, através das leis $2497 / 72$ e $2513 / 78$ reduziu o afastamento frontal mínimo para dois metros frontais".

"Ilegalidade. Considero também ausente este requisito para o acolhimento da ação popular. O Decreto estadual $\mathrm{n}^{\circ} 52.497$, de 217.70 , inegávelmente é um regulamento, ou seja, um ato administrativo posto a vigorar para o fim de especificar os mandamentos do decreto lei estadual $n^{\circ} 211$ de 30.3.70. Esse apontado decreto lei dispõe sobre "normas de promoção, preservação e recuperação da saúde no campo de competência da Secretaria de Estado da Saúde"'. "Contém apenas 25 artigos, nada tratando a respeito das exigências minimas dos loteamentos de imóveis em geral. Assentou tão somente caber à Secretaria da Saúde "entrar com órgãos normativos e executivos, destinados a proporcionar... o controle... (XVI, do artigo $\left.3^{\circ}\right)$, dos loteamentos de imóveis..." De igual modo não tem uma palavra $x$ a respeito do sentido estético dos loteamentos, já que o campo de ação é a saúde". çâo Saraiva, 1977, pg. 217 , que deve ser transcrito:

"Um problema surge quando se adota o princípio da legalidade, qual seja o de se saber se, naquelas matérias, em que é omissa a lei, pode o "executivo" editar regras obrigatórias. É o problema dos regulamentos "praeter legem". Em princípio, como é sabido, o regulamento não pode criar ou estinguir obrigaçōes, não pode nem mesmo suspendê-las ou adiá-las como não amplia nem restrige direito. Por outro lado, se costuma ensinar que, no que for além da lei, não obriga, no que for contra a lei, não prevalece. À luz desse ensinamento, que é o clássico, o regulamento praeter legem não obriga. Deve-se observar, todavia, que a doutrina e a jurisprudência o que tem admitido como válido, desde que fundamente em competência constitucionalmente conferida. Assim, se a matéria, na Conşituiçâo, foi atribuida ao "Executivo", não havendo lei que regule os direitos e obrigaçōes nessa esfera, pode aquele poder ditar as regras necessárias, criando obrigaçōes, conferindo direitos"

"Não conta o poder a explicar, não obriga, invadida foi a competência do Poder Legislativo. A improcedência da ação é, destarte, inafastável. Pela motivação extendida e pelo mais constantes destes autos, julgo improcedente a ação" - concluiu o Magistrado.

A propósito do decreto $52497 / 70$, esta havia servido de fundamentação no entender dos engenheiros e nele se basearam os profissionais que impetraram a ação popular ora julgada improcedente, com o que tentaram anular a legislaçâo municipal que alterou o Plano Diretor.

A defesa contou com os advogados dr. Olintho Santos Novais, Procurador Jurídico, pela Prefeitura Municipal e dr. Luis Carlos Faria Soares, diretor do Departamento Juridico da Câmara.

O processo agora deverá ser apreciado pelo Egrécio Tribunal de Justiça de S. Paulo, tendo em vista que na própria sentença, por se tratar de Poder Público, no caso Prefeitura e Câmara, o próprio Juiz recorre.

Diante do exposto, enquanto não ocorrer a apreciação pelo Tribunal da capital, a lei do Plano Diretor, sancionada pelo

Executivo depois de nomuads nols râmo

Figura 22. Técnicos são derrotados em disputa jurídica sobre alterações do Plano Diretor 
A questão dos prédios altos, que estava relacionada, de um lado, aos interesses do setor imobiliário, que desejava implantar novos empreendimentos imobiliários através da construção de arranha-céus no centro da cidade e, de outro, a uma visão de "desenvolvimento da cidade", constituiu-se num elemento de debate constante nos anos 1970, com variadas críticas à administração pela sua postura rígida em somente aprovar projetos que estivessem obedecendo integralmente a lei existente, o que reduzia a possibilidade de efetivar novas obras no centro da cidade, por conta da dimensão reduzida dos terrenos e da baixa capacidade da infra-estrutura de água e esgoto naquela região. Essa crítica ao governo é recorrente na imprensa, vista como uma postura que trava o desenvolvimento da cidade, enquanto a administração se defende afirmando que o centro da cidade não oferece condições para a verticalização excessiva, por conta das citadas carências de infra-estrutura e do sistema viário ${ }^{32}$.

Na verdade, o debate público, seja na Câmara ou na imprensa, que se trava em torno do Plano Diretor sempre se situou em dois eixos principais: de um lado, na legislação de parcelamento do solo, que afetava a produção de novos loteamentos, cuja produção em grande escala era vista como uma maneira de impedir o surgimento de favelas na cidade; do outro, o da implantação da edificação no lote, incluindo recuos e taxas de ocupação.

Ou seja, elementos muito mais ligados aos interesses da produção privada do ambiente construído que às diretrizes gerais que o poder público dispunha para intervir no espaço urbano, como o sistema viário e o Distrito Industrial, este sempre descrito como uma demanda da cidade (e não do setor industrial). Ainda em 1978, é criado pelo governo municipal o Pladein, um programa de desenvolvimento industrial cujo objetivo central é implantar o distrito industrial, um dos mais importantes aspectos do Plano Diretor, que será tratado detalhadamente no Capítulo 4.

No bojo da reorganização partidária do início dos anos 80, após a manobra política efetuada pelo regime militar que resultou na prorrogação do seu mandato por dois anos, o prefeito Maurício transferiu-se para o PDS (sucedâneo da ARENA) e Ary Balieiro, então vereador do grupo de Maurício migrou para o PMDB, lançando-se posteriormente candidato a vice-prefeito na vitoriosa chapa de Sidnei Franco da Rocha, vereador e líder da oposição, que tinha sido assessor de esportes da segunda gestão de Hélio Palermo ${ }^{33}$.

A partir destes episódios, reduzem-se as modificações pontuais da lei do Plano Diretor Físico, que vai sofrer outra alteração de maior porte no início do governo de Sidnei Rocha, em 1983, exatamente sob a alegação de permitir a construção de prédios altos e dinamizar o setor da construção civil ${ }^{34}$, questão que estava presente até mesmo no plano de governo de Sidnei Rocha.

Como o arquiteto Ary Baleiro elegeu-se vice de Sidnei Rocha, foi convidado a

\footnotetext{
${ }^{32}$ DIÁRIO DA FRANCA de 16 de julho de 1979, p.2.

${ }^{33}$ Hélio Palermo faleceu em 1977, menos de um ano após sua saída da Prefeitura.

${ }^{34}$ Logo que Sidnei Rocha assumiu, fui exonerado do cargo de arquiteto da Prefeitura. Nesta época, eu já estava militando no PT, como um dos seus fundadores na cidade. Os engenheiros Wilson Teixeira e Weber David, bem como o arquiteto Luiz do Couto Rosa permaneceram nos quadros técnicos da Prefeitura.
} 
assumir a direção da antiga assessoria de Planejamento, agora transformada em Secretaria de Planejamento. As propostas do Plano sofrem novo impulso, embora Balieiro negue grande influência do mesmo. A abertura de novas avenidas e obras viárias são priorizadas pelo governo municipal. Mas também outras propostas do Plano começam a se tornar realidade, como o Distrito Industrial, implantado e inaugurado em 1984.

Balieiro $^{35}$, em depoimento ao autor, afirma que:

“Então o Plano Diretor na realidade, nós tínhamos como ponto de referência, o que podia e o que não podia. Aí teve aquela polêmica de que, quando nós fomos eleitos prefeito e vice-prefeito, que Franca não tinha prédios altos porque o Maurício não deixava construir, nós fomos olhar era só mudar o ângulo diedro e pronto, o gabarito permitia, fizemos essa mudança ${ }^{36}$, mas acho que essa foi uma coisa tão minúscula, que Franca continuou, essa é minha paixão, com a sua vocação de crescimento horizontal $^{37}$ (...) eu me lembro que eu recebi, quando prefeito, que eu recebia outros prefeitos, eles ficavam impressionados, com ruas largas, arborizadas, uma cidade onde se respira, nossa como vocês conseguiram, vocação da cidade, nunca ninguém impediu nada. O Plano, o sistema viário, foi pensado no governo do Maurício ${ }^{38}$ e foi concretizado no nosso, quando eu fui secretário de Planejamento (...) preciso de 90 dias, eu vou fazer um plano de intervenção na cidade nas áreas de urbanismo, urbanização, sistema viário, educação, saúde e promoção social, e paisagismo. Aí fizemos o projeto do sistema viário da cidade, fizemos o levantamento de todos os bairros, o que estaria faltando, na prefeitura, postos de saúde, escola, localizamos tudo para ele, e fizemos um projeto, aí entrou o calçadão, disse é uma obra que a gente tem que fazer, é o que o povo quer, que vai alavancar aquele centro, tinha uma polêmica se era pior ou melhor para o trânsito, eu nunca me preocupei com o trânsito no centro da cidade, a não ser com o estacionamento, são ruas estreitas, não adianta v. ficar pensando em muita coisa não. Aí, ele (Sidnei) pegou aquele plano e concordou. Só que o início mesmo foi quando o Quércia veio aqui, eu fiz o calçadão (...) entregamos no dia do aniversário da Franca (...)."

Ary Balieiro substituiria definitivamente Sidnei Rocha, que abandonou a prefeitura para assumir um cargo estadual em 1987, completando o mandato de seis anos, que se encerraria em 1988. Durante este período ${ }^{39}$, quando assumiu a secretaria de Planejamento o engenheiro Wilson Luiz Teixeira, foi pedestrianizado considerável

\footnotetext{
${ }^{35}$ Entrevista gravada concedida ao autor em 19/01/2005.

${ }^{36}$ Ary refere-se a uma das principais críticas de Sidnei Rocha ao Plano Diretor quando estava na oposição, afirmando que sua aplicação impedia a verticalização da cidade.

${ }^{37}$ Ary, enquanto dirigente público e empreendedor imobiliário, sempre defendeu esta pretensa "vocação horizontal" de Franca.

${ }^{38}$ Em relação ao Plano Viário, a referência expressa, na verdade, a elaboração de um Plano do qual participei, enquanto técnico da Secretaria de Planejamento, das avenidas para expansão urbana, além dos limites do Plano Diretor de 1972. ${ }^{39}$ Durante este mesmo período, fui membro do Diretório Municipal do PT - Partido dos Trabalhadores, exercendo atividades ligadas à oposição ao governo Sidnei-Ary, principalmente de formação política e de elaboração de propostas na área de urbanismo e habitação para o único vereador eleito pelo PT (Aníbal Vilela Moreira), bem como colaborando regularmente com o jornal Diário da Franca, escrevendo artigos sobre planejamento urbano.
} 


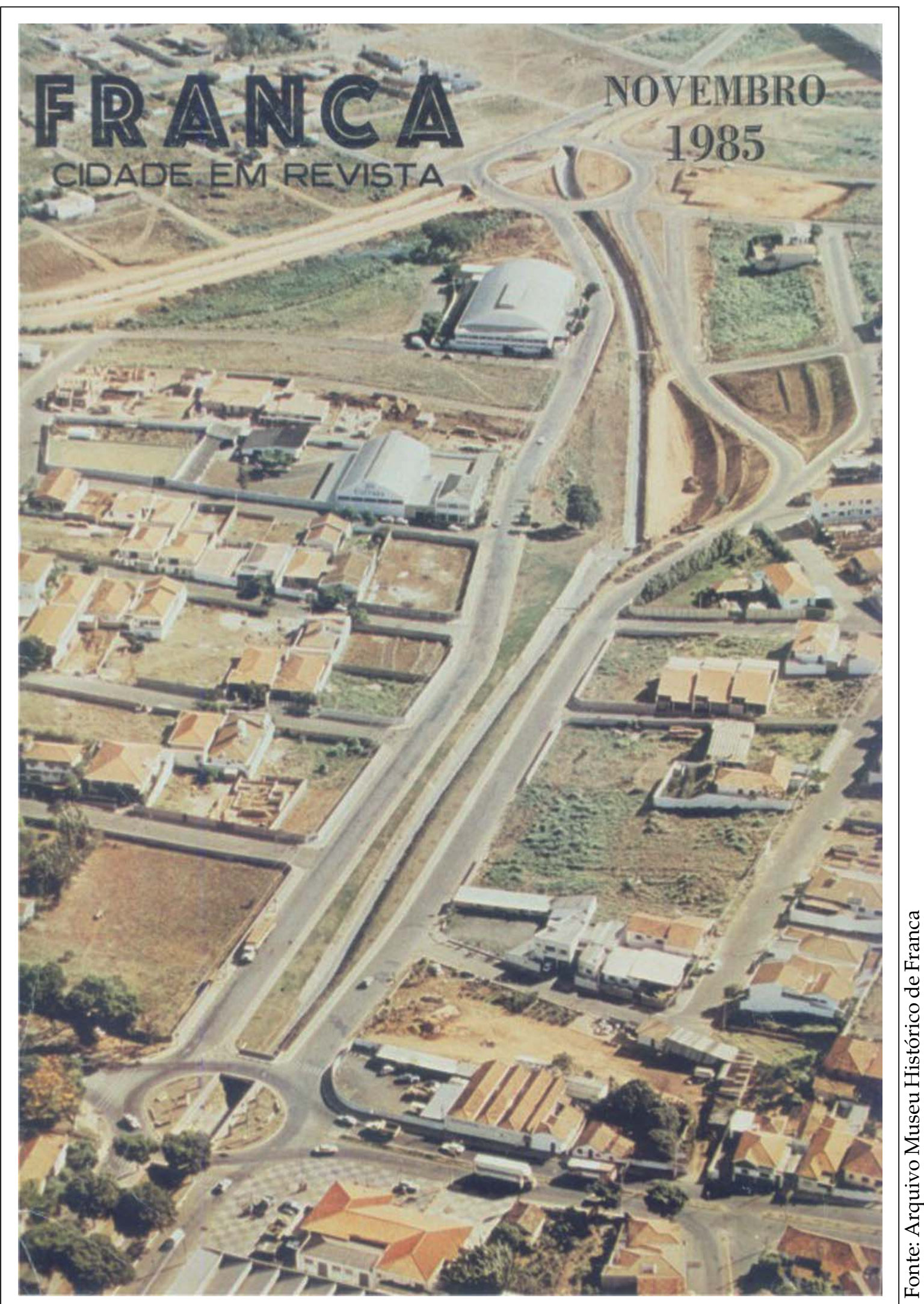

Figura 23. Obras de ampliação da avenida marginal ao córrego do Cubatão e do sistema viário na região 
trecho do centro da cidade, construída a avenida da Integração e urbanizada a voçoroca de Higienópolis, que recebeu a denominação de Jácomo Filetto.

Em 1989, assumiria o cargo de prefeito novamente Maurício Sandoval Ribeiro, abrigado agora na legenda do PTB, que manteve Wilson Teixeira como secretário de Planejamento, bem como Couto Rosa e Weber David em cargos na EMDEF e secretaria de Obras. Neste período ${ }^{40}$, uma grande intervenção urbana é realizada no vale dos Bagres, destruindo a queda d'água natural existente e suas características iniciais para implantar uma avenida de fundo de vale, não prevista no Plano.

Em 1993, retornaria ao cargo de prefeito Ary Balieiro, (ainda pelo PMDB, partido que trocaria no meio do mandato pelo PTB) que iria dar continuidade à extensão das avenidas de fundo de vale dos córregos do Cubatão e do Bagres, bem como realizar intervenções na voçoroca das Maritacas e do Parque São Jorge. Weber David e Couto Rosa se aposentaram, porém Wilson Teixeira continuou à frente da secretaria de Planejamento, até o final do mandato de Ary Balieiro, em $1996^{41}$.

Quase 25 anos depois da aprovação da Lei do Plano Diretor Físico oriundo do processo de planejamento decorrente do financiamento do SERFHAU, suas principais propostas estavam implementadas ou superadas, evidenciando os seus limites, esgotando-se definitivamente um ciclo do planejamento da cidade ${ }^{42}$.

\footnotetext{
${ }^{40}$ Já nesta época, tornei-me assessor técnico para assuntos de habitação e urbanismo do vereador Gilmar Dominici (PT), emergente liderança oposicionista.

${ }^{41}$ Neste novo mandato de Balieiro, permaneci na assessoria técnica do vereador Gilmar Dominici (PT), da oposição. Em outubro de 1996, em substituição a Balieiro, Dominici (PT) seria eleito prefeito de Franca, convidando-me para assumir a pasta do Planejamento.

42 Verificar Quadro 1 nos Anexos, que mostra os principais agentes governamentais do Executivo durante o período de vigência do Plano Diretor de Franca, principalmente técnicos e prefeitos. Por ele, podemos verificar que nos últimos trinta anos, participei ativamente do processo de implantação e revisão do Plano Diretor, como quadro técnico e dirigente político do governo e da oposição, fui personagem e observador privilegiado, motivo pelo qual a isenção total será impossível ser obtida, ao olhar e recortar o objeto da pesquisa. Porém, até mesmo por isso, para entender e resgatar aspectos que considero importantes da história do planejamento e do urbanismo local, considero ter obrigação de aceitar os enormes desafios que tal tarefa propõe: observar, inobstante as limitações apontadas, com rigor científico e verificar em que medida o Plano repercutiu sobre cidade, como um possível conjunto de compromissos de governo e das lideranças locais (mesmo que cheia de idas e vindas), bem como do debate político sobre o desenvolvimento urbano de Franca.
} 


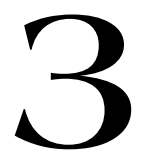

\section{PLANO DIRETOR FÍSICO DE 1972: MODELO DE RACIONALIDADE TÉCNICA?}

O Plano Diretor Físico de Franca foi aprovado e transformado em lei municipal na administração de José Lancha Filho (1969-1973) em 6 de janeiro de 1972 (Lei 2.046), resultado de um longo processo de elaboração que se inicia em 1967, durante a primeira gestão do prefeito Hélio Palermo (1964-1969), até ser aprovado definitivamente na sessão da Câmara Municipal realizada no dia 27 de dezembro de 1971. O objetivo da Lei do Plano Diretor Físico, expresso nos dois primeiros artigos da lei, era "ordenar e disciplinar o desenvolvimento de forma integrada e harmônica, e propiciar o bem-estar social da comunidade francana, instituindo normas ordenadoras e disciplinadoras pertinentes ao planejamento físico do Município".

O projeto de lei do Plano Diretor Físico fazia parte do escopo de um trabalho intitulado Plano de Desenvolvimento Integrado de Franca, iniciado em 1967 e elaborado por uma empresa de consultoria com sede na capital paulista, o GPI - Grupo de Planejamento Integrado. Em sua forma final, o Plano foi apresentado em cinco volumes encadernados, contendo o Diagnóstico, a Política de Desenvolvimento Físico, a Lei do Plano Diretor Físico, o Plano de Ação e a Viabilidade do Distrito Industrial.

No entanto, até chegar aos produtos citados, houve um longo percurso, dividido em várias etapas: uma reestruturação administrativa, a introdução de legislação de pessoal, organização e métodos para a ação burocrática, a estruturação de um cadastro técnico, até se chegar à lei do Plano Diretor propriamente e à implantação de obras. $\mathrm{O}$ primeiro produto visível do contrato com o GPI foi a lei municipal 1.559, de 23 de novembro de 1967, que instituiu um "Sistema de Planejamento do Desenvolvimento Integrado do Município", que consistia na determinação de diretrizes para promover o 
desenvolvimento integrado de Franca e fornecia as bases conceituais e institucionais para a implantação de um processo permanente de planejamento e do Plano Diretor.

O objetivo do Sistema, segundo previa a lei, dentre outros aspectos, era imprimir racionalidade e dinamismo à ação do executivo, desenvolver equilibrada e racionalmente o município e programar adequadamente os investimentos. O sistema exigia obrigatoriamente a existência de um órgão de planejamento, subordinado diretamente ao prefeito, visando assegurar eficácia operacional ao planejamento integrado, ou seja, já impõe um modelo que estava na base das teorias desenvolvidas pelo SERFHAU: que o planejamento deveria constituir um organismo visceralmente ligado ao prefeito, que coordenaria todas as demais ações governamentais, como forma de superar os "problemas urbanos" e seus desafios. A criação de um órgão de planejamento era considerada indispensável para o financiamento, conforme exigência da legislação que criou o próprio SERFHAU e provavelmente sua formatação como assessoria direta do prefeito, que não levava em conta a existência do Departamento de Planejamento e Urbanismo criado desde o final de 1963, visava atender as diretrizes daquele organismo federal.

O artigo 15 da lei estabelecia ainda as finalidades do Plano Diretor Físico, que visaria assegurar o desenvolvimento físico racional, harmônico e estético das estruturas urbanas e rurais. Além disso, a lei definia também diretrizes para a programação orçamentária e financeira da prefeitura, bem como da racionalização administrativa da prefeitura, para atender exigências de racionalidade e produtividade da administração.

Uma nova reorganização administrativa, definida logo em seguida através da lei 1.560, de 1 de dezembro de 1967, estabeleceu um novo organograma da prefeitura de Franca, onde se constitui na estrutura da Prefeitura uma Assessoria de Planejamento com status de secretaria, e um Conselho de Desenvolvimento Integrado, órgão consultivo que seria responsável pela formulação da política municipal de desenvolvimento e dos planos correspondentes.

A nova estrutura, definida no artigo 9 da lei 1560/67, era assim composta:

I - Órgãos de Assessoramento:

a) Conselho de Desenvolvimento Integrado de Franca;

b) Comissão Municipal de Esportes;

c) Assessoria de Planejamento;

d) Gabinete do Prefeito;

II - Órgãos Auxiliares:

a) Secretaria de Administração;

b) Procuradoria Jurídica;

c) Secretaria de Finanças.

III - Órgãos Afins

a) Secretaria de Serviços Urbanos;

b) Secretaria de Educação e Cultura;

c) Secretaria de Obras Públicas. 
Ambas as leis tiveram suas minutas idealizadas pelo GPI, já no âmbito do contrato do futuro Plano Diretor. Ao mesmo tempo, iniciaram-se os trabalhos de reorganização interna de fluxos e de métodos de serviço, de adequação do orçamento-programa e do recadastramento urbano, com o objetivo de atualizar e modernizar o cadastro técnico imobiliário. Para isso, foram realizadas medições em campo, lote por lote, a definição de uma lógica para o funcionamento do cadastro e a estruturação de uma base de dados do espaço físico da cidade mais confiável, que serviria de suporte às propostas do Plano 1 .

A idéia de constituir uma assessoria específica de planejamento vinculada ao gabinete do Prefeito é parte da substituição da estrutura da Prefeitura em vigor naquele momento, que havia sido modificada recentemente, a partir da lei municipal 1.204, de 22 de dezembro de 1963, que criou um Conselho de Planejamento cuja competência incluía opinar sobre o Plano Diretor do Município (que não existia). Na nova lei (n. 1560) apresentada pelo GPI e aprovada pela Câmara no final de 1967, as secretarias de Obras Públicas e de Serviços Urbanos substituíam o Departamento de Viação e Obras Públicas. A Assessoria de Planejamento substituía o Departamento de Planejamento e Urbanismo. As demais modificações consistiam apenas na transformação das estruturas de departamentos existentes em Secretarias. O Conselho de Desenvolvimento Integrado seria presidido pelo prefeito e era constituído, nos termos do artigo 13 da lei 1560, por nove membros designados pelo prefeito, devendo ter a seguinte composição:

a) O chefe da Assessoria de Planejamento;

b) O secretário de Obras Públicas;

c) O diretor da Superintendência de Água e Esgotos;

d) Um representante do Conselho Municipal de Ensino Superior, que seja professor universitário;

e) Um representante da Associação Rural de Franca;

f) Um representante da Associação Comércio e Indústria de Franca;

g) Um representante do Rotary Club;

h) Um representante do Lions Club.

A equipe responsável no GPI para elaborar as propostas de ordem física apresentadas no Plano foi constituída basicamente pelos arquitetos Heitor Ferreira de Souza e pelo arquiteto Jairo José Farias. Na prefeitura, participaram diretamente o arquiteto Luiz do Couto Rosa e o engenheiro civil Weber Drauzio David. O GPI utilizou também, para as questões ambientais, os alentados trabalhos que o geógrafo Aziz Ab’Saber havia feito sobre o solo e os processos erosivos existentes no planalto de Franca, principalmente por causa do impacto da erosão e dos problemas de uso e ocupação do

\footnotetext{
${ }^{1}$ Nas entrevistas de José Suavinho e Marco Résio, concedidas ao autor em 5 e 17/01/2005, respectivamente, apontouse a reorganização interna da Prefeitura e de modernização de seus métodos de trabalho, como uma das tarefas de maior visibilidade do processo de planejamento implantado. Já Weber David, entrevistado em 25/03/2003, afirma que o recadastramento imobiliário foi, em sua opinião, um dos mais importantes aspectos do Plano.
} 
solo ocasionados pelas voçorocas urbanas, cujas diretrizes foram incorporadas ao projeto de lei. O estudo específico do Distrito Industrial, principalmente na área econômica, ficou sob a responsabilidade do sociólogo Maurício Cadaval e a parte física ao arquiteto Jairo José Farias. A lei do Plano Diretor, segundo depoimento de Cadaval, teria sido elaborada por Diógenes de Arruda Câmara.

\section{O DIAGNÓSTICO: INTERPRETAÇÃO REALISTA DA CIDADE}

O volume que trata do Diagnóstico sintetiza, de forma bastante didática, as principais questões julgadas prioritárias pelo GPI a serem enfrentadas no que se refere à estruturação do espaço urbano:

- a estrutura viária insuficiente, carecendo de hierarquização do tráfego, de ligações entre os diversos bairros e o centro, e a necessidade de se criar condições de circulação para os pedestres;

- a necessidade de controlar a expansão urbana, até mesmo através da proibição de novos loteamentos, a indução ao adensamento de áreas com baixa densidade populacional;

- a falta de um zoneamento racional do uso do solo que dificultava a expansão industrial;

- a carência de áreas verdes para fins paisagísticos.

Em relação a este último aspecto, acrescentou-se uma análise aprofundada do grave problema ocasionado pelas voçorocas existentes dentro da estrutura urbana, tanto para a expansão da cidade, para a qualidade ambiental e para a segurança dos moradores vizinhos, pois muitas delas mantinham atividade, ampliando sua área de influência.

Sabe-se que a questão das voçorocas e da erosão já estavam presentes nas preocupações da administração local desde o final do século XIX, pois

\footnotetext{
“em 1887, prevendo a expansão da cidade por causa da chegada da ferrovia, foi apresentada uma indicação para que a Câmara reivindicasse à Assembléia Provincial uma verba de vinte contos de réis para ser aplicada nos concertos de diversas ruas, entupimento das grandes vossorocas que existem, não só no caminho da estação da via-ferrea, como mesmo unido à cidade, onde pode cauzar grandes prejuizos". (FOLLIS, 2004:76)
}

O volume que trata do Diagnóstico expõe ainda um amplo leque de informações sobre a cidade e a região, assim como "as principais análises e conclusões sobre os aspectos da realidade municipal e regional de Franca que interessam ao planejamento integrado do Município", como escrevem os autores do Plano. Segundo o GPI, buscavase captar a situação da cidade naquele momento, como uma etapa do seu processo histórico de desenvolvimento, que "permitirá que sejam equacionados de modo racional e objetivo os problemas a serem enfrentados pela comunidade". (PREFEITURA MUNICIPAL DE FRANCA, [1971?a]:1) 
São levantados aspectos fisiográficos do planalto de Franca e o sistema de polarização regional, incluindo-se seus limites, a demografia e a economia regional, assim como suas inter-relações. Desenvolve-se também um fundamentado histórico do município, desde as suas origens e formação, até o desenvolvimento da indústria coureiro-calçadista. A evolução demográfica é exaustivamente estudada, desde o crescimento, os movimentos populacionais, a população urbana e rural, a sua composição etária e as tendências daquele momento. Realizou-se ainda uma extensa análise das estruturas econômicas, principalmente da indústria de calçados. O trabalho aborda, de forma detalhada, as estruturas urbanas, que são as que mais nos interessam pelo aspecto físico.

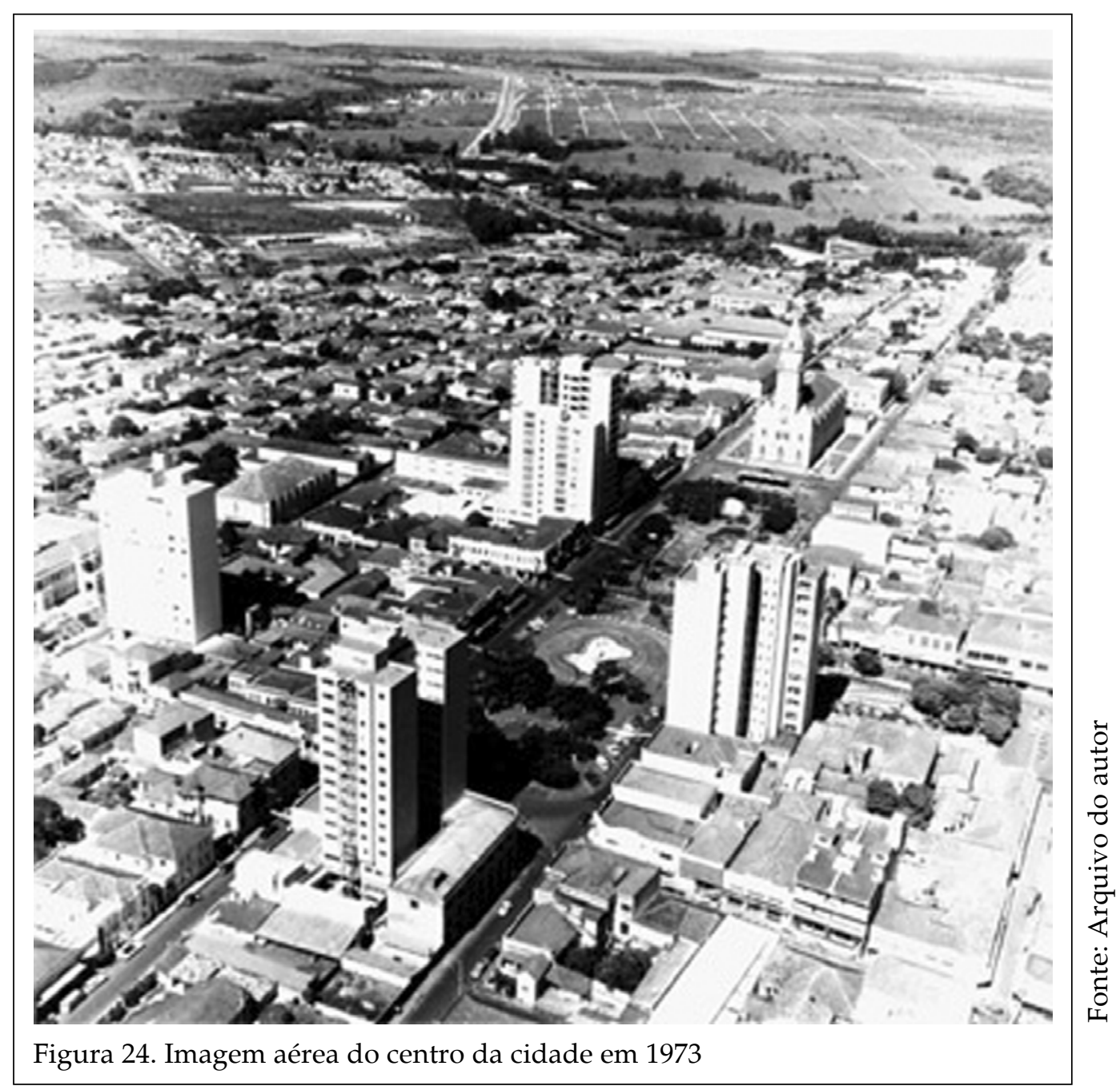

Ao final, o Diagnóstico, longe de ser uma peça acadêmica ou desvinculada da realidade local, realiza uma operação analítica que demonstra coerência das propostas para uma cidade de porte médio sem grandes recursos, tais como sua posição contrária a grandes obras viárias e ressaltando a necessidade de apoiar e desenvolver a indústria calçadista para além dos limites do mercado nacional. Também a radicalidade da proposta de controle da expansão urbana, calcada na dificuldade econômica e insuficiência da arrecadação que levavam à impossibilidade da Municipalidade em prover serviços em quantidade e qualidade necessárias ao ritmo de crescimento da cidade, ao contrário de apontar sua 
irrealidade política, demonstra coerência técnica com a análise da realidade local.

A idéia de um planejamento que abrange a questão regional está presente no Diagnóstico, traduzido no estudo da área de influência imediata do município:

"Franca se comporta regionalmente como verdadeiro escoadouro para onde convergem os principais influxos sócio-econômicos dos demais sub-setores". O estudo revela haver uma tendência acentuada à urbanização da cidade pólo, em contraste com o ritmo bastante pequeno de crescimento demográfico e urbanização das demais pequenas cidades do seu entorno. A polarização em torno de Franca é acentuada em todos os aspectos, desde o comércio e a prestação de serviços, porém "a insuficiência de equipamentos médico-hospitalares e de ensino médio nos núcleos urbanos da região é motivo para uma freqüente sobrecarga nos hospitais e escolas da cidade de Franca, acarretando um considerável ônus para o contribuinte da cidade pólo" (PREFEITURA MUNICIPAL DE FRANCA, [1971?a]:13).

O crescimento demográfico apontava uma forte tendência para a concentração populacional na cidade, com o esvaziamento da zona rural, ou seja, já se configurava a tendência da cidade assumir a condição de um pólo regional. Em 1960, segundo o censo do IBGE, 82,9\% da população de Franca já era urbana, atingindo 47.244 habitantes dos 56.987 do Município. Ao mesmo tempo, o estudo concluía que as principais perspectivas de desenvolvimento na agricultura estavam vinculadas à cultura do café, incluindo medidas para combater a exaustão do solo e a baixa produtividade, assim como a constituição de uma cooperativa de produtores.

As análises do trabalho denotavam ainda que a evolução da economia industrial não deixava dúvidas quanto ao potencial da indústria calçadista, embora "um tal grau de integração da indústria francana em torno de uma só atividade polarizadora faz com que se torne extremamente vulnerável" (PREFEITURA MUNICIPAL DE FRANCA, [1971?a]:93). O estudo apontava também a necessidade de reorganizar o setor calçadista, "seja introduzindo novas técnicas, seja abrindo-a à penetração de capitais externos ou conquistando novos mercados" (PREFEITURA MUNICIPAL DE FRANCA, [1971?a]:95). O depoimento de Maurício Cadaval é revelador da importância assumida pelo setor, após a realização do Plano:

"Eu e o Luciano Coutinho (que foi meu estagiário no Plano de Franca) fomos convidados para fazer uma palestra sobre a indústria de calçados, a propósito da implantação de um Distrito Industrial, previsto no Plano. Naquela época a indústria local não exportava, trabalhando apenas para o mercado interno. Não sei por que razão apontamos a exportação de calçados como uma perspectiva promissora para o desenvolvimento da economia local, uma vez que o café mostrava sinais de decadência. Não houve muitos debates sobre o tema. Depois de terminados os estudos, o Prefeito de Franca e dois industriais locais foram me visitar em São Paulo e fizeram a proposta para que eu dirigisse um grupo de oito indústrias de calçados que estavam interessadas em se lançar na exportação" ${ }^{2}$.

${ }^{2}$ Entrevista ao autor por e-mail, 19 de dezembro de 2005, 10:34 h. 


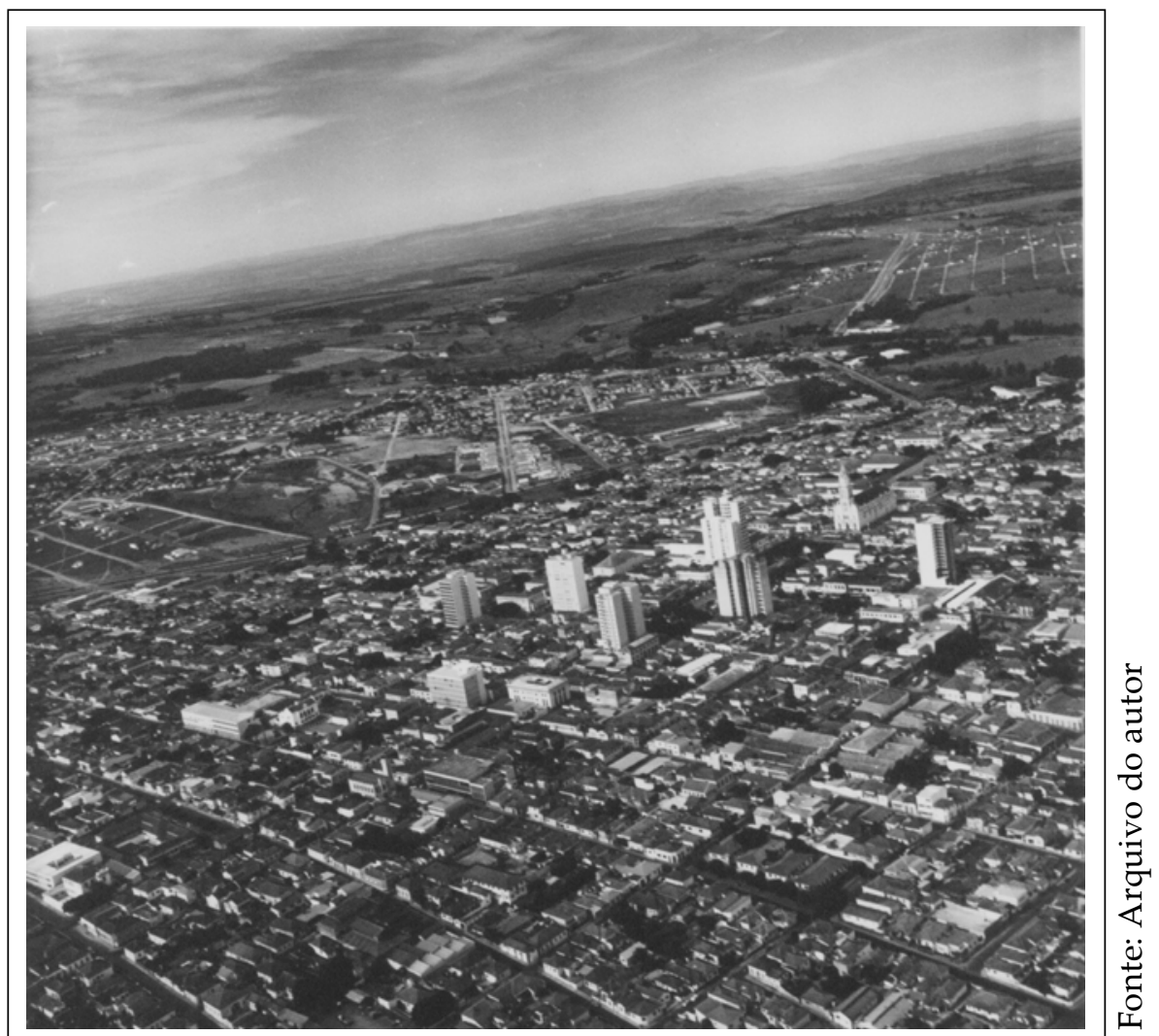

Figura 25. Franca por volta de 1973: escassa verticalização e novos bairros na periferia.

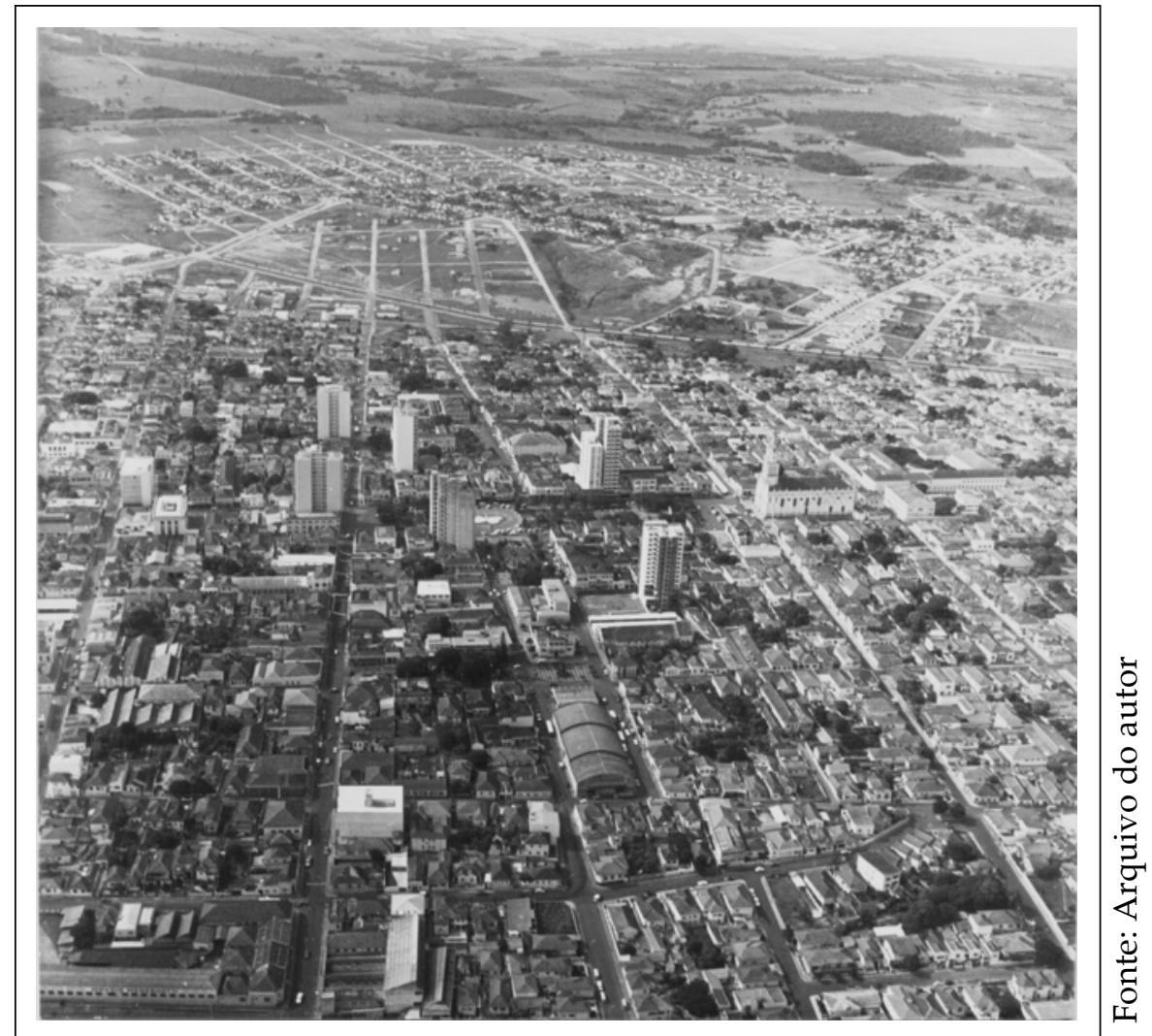

Figura 26. Novos bairros são rapidamente constituídos, no início dos anos 70 . 
Esta movimentação dos segmentos industriais calçadistas revelam uma participação, a partir das discussões do Plano, que não transparece ostensivamente, seja nos documentos ou na literatura disponível. Mas parece importante assinalar que este desejo dos industriais, de ingressarem no mercado internacional e ampliar sua participação no mercado nacional vai demarcar uma ação do poder público local neste sentido, ao incluir no Plano Diretor a necessidade da construção de um Distrito Industrial, bem como a construção de um centro de exposições, que vai fazer parte do Plano de Ação elaborado pelo GPI.

A estrutura urbana, conforme aparece no Diagnóstico,

\begin{abstract}
"revela, quanto à sua evolução, um comportamento senão totalmente espontâneo, pelo menos comodista. A malha reticulada que o tecido urbano assume onde hoje se encontra o centro comercial da cidade, demonstra a intervenção humana disciplinando o traçado original. Daí em diante são nítidas as sucessivas pulsações da estrutura urbana, ora prolongando as ruas do traçado original, ora agregando novas malhas onde as ruas são defletidas, conservando a continuidade das originais, mas se acomodando, sempre que possível, às condicionantes topográficas e demais barreiras físicas." (PREFEITURA MUNICIPAL DE FRANCA, [1971?a]:110)
\end{abstract}

A abertura de novas avenidas preparadas a suportar tráfego em duplo sentido, como as avenidas marginais aos córregos, projetadas e construídas em parte, como importante elemento de modernização do sistema viário da cidade é enfatizada. Em geral, "Franca tem o esquema de sua malha viária em forma quadricular ou retangular, não ortogonal aos eixos geográficos". Sua trama viária "não foi dimensionada com base na hierarquização do tráfego." (PREFEITURA MUNICIPAL DE FRANCA, [1971?a]:111)

O Diagnóstico aponta também que, dadas as condições do momento, seria necessário atingir os objetivos acima sem grandes obras viárias e desapropriações de grande vulto, inclusive em função da precária situação das finanças municipais. De certa forma, o estudo apontava a necessidade de investimento no sistema viário, através da criação de uma base de circulação e mobilidade urbana que possibilitaria sua expansão sem grandes traumas urbanísticos.

O estudo afirma, em relação ao zoneamento de uso do solo, que o chamado processo de crescimento espontâneo criou dois "núcleos principais de animação, com concentrações comerciais mais densas e marcantes: a praça principal e a praça em frente à Estação, comportando-se ainda o primeiro como o coração da cidade". A análise feita no trabalho indica "um diagnóstico pouco favorável, quer na hipótese de manutenção das ruas nas condições atuais, quer na hipótese de aplicação de cirurgia urbana para o alargamento das ruas excessivamente estreitas", considerando que na proposta do Plano seriam indicadas soluções para a circulação de pedestres e veículos, valorizando a região central da cidade. (PREFEITURA MUNICIPAL DE FRANCA, [1971?a]:113)

Ainda quanto ao zoneamento de uso do solo, critica-se o "clássico conflito de usos comuns às cidades não planejadas", que agravam o tecido urbano, como a "poluição ambiental, ruídos, inserção de transportes pesados em quantidades crescente na malha 
de ruas inadequadas ao trânsito, à carga e descarga de matérias-primas e produtos, etc." (PREFEITURA MUNICIPAL DE FRANCA, [1971/a]:114)

A análise da densidade populacional destaca "o problema da rarefação do tecido urbano de Franca, pois as taxas de ocupação revelam valores baixíssimos, que vem constituindo ônus sérios e crescentes à Municipalidade, para atendimento de equipamentos básicos, como rede de água, esgotos, pavimentação, galerias de águas pluviais, etc.". Ou seja, "Franca tem contra si a liberdade de expansão para todos os quadrantes, que vem permitindo o espraiamento empírico do seu tecido urbano com tendência a forte rarefação." (PREFEITURA MUNICIPAL DE FRANCA, [1971?a]:116)

Os quadros referenciais utilizados pelo GPI mostram que se a densidade permanecesse em 95 hab/ha, haveria ainda 623 hectares para serem ocupados, sem a necessidade de produção de novos loteamentos, onde seria possível instalar mais 70 mil habitantes, quando a cidade possuía em 1970, cerca de 93.613 habitantes ${ }^{3}$.

Para o Diagnóstico,

\begin{abstract}
"trata-se, incontestavelmente, de uma exacerbação injustificada do crescimento horizontal da cidade. Quando da análise do atendimento de cada equipamento, podem ser observadas as graves implicações desta situação para a implementação das redes de água, esgoto, pavimentação, energia elétrica, etc. O custo per capita dessas instalações atinge valores elevados que desencorajam os órgãos públicos em beneficiar os bairros mais distantes até mesmo com equipamentos tão fundamentais como as redes de água e esgotos. Imperioso se faz, portanto, a adoção de dispositivos legais que possam estancar, durante determinado período, os limites da área loteada atual incentivando a densificação e ao melhor uso das áreas disponíveis" (PREFEITURA MUNICIPAL DE FRANCA, [1971?]:118).
\end{abstract}

Quanto aos equipamentos de infra-estrutura, foi realizada uma análise detalhada dos serviços locais, principalmente água, esgotos sanitários, energia elétrica e iluminação pública, pavimentação de ruas, galerias de água pluviais, coleta e limpeza pública, dentre outros aspectos ligados à provisão de serviços públicos.

Tabela 5. Evolução da População do Município de Franca entre 1940 e 2000

\begin{tabular}{|c|c|c|}
\hline Ano & População $^{\mathbf{1}}$ & Estimativa $^{\mathbf{2}}$ \\
\hline 1940 & 29.638 & \\
\hline 1950 & 36.176 & \\
\hline 1960 & 56.987 & 90.000 \\
\hline 1970 & 93.638 & 156.000 \\
\hline 1980 & 148.505 & 478.100 \\
\hline 1991 & 233.099 & \\
\hline 2000 & 286.737 & \\
\hline
\end{tabular}

1. Dados dos Censos IBGE

2. Estimativa do GPI no diagnóstico do Plano Diretor, p.47

${ }^{3}$ Censo IBGE 1970. 
A POLÍTICA DE DESENVOLVIMENTO FÍSICO: BASE DAS PROPOSTAS PARA A CIDADE E SEU FUTURO INDUSTRIAL

O volume intitulado Política de Desenvolvimento Físico foi dividido em quatro capítulos de propostas, tratando de fazer, após uma Introdução geral, as Proposições Básicas, as Proposições de Zoneamento de Uso do Solo, as Proposições do Sistema Viário, Circulatório e de Hierarquização das Vias e, finalmente, as Proposições de Equipamentos Comunitários.

Neste volume, além de descrever detalhadamente e justificar as propostas, procura-se imprimir uma ordem de importância e de urgência às proposições do Plano.

São duas as proposições básicas do Plano: o imediato cerceamento da expansão dos loteamentos e a necessidade de aprovar sem alterações o zoneamento de uso do solo.

A proposta de congelamento dos loteamentos visava conter o "processo de expansão da cidade injustificado e danoso, de características megaloplanimétricas, cujos prejuízos às finanças públicas tendem a se agravar se medidas corretivas não forem adotadas a tempo" (PREFEITURA MUNICIPAL DE FRANCA, [1971?e]:3). De acordo com o estudo, os loteamentos estavam sub-utilizados e sem infra-estrutura, o que levaria a Prefeitura no futuro a ter que disponibilizar os serviços públicos sem que houvesse a necessária viabilidade econômica.

Além desta questão, o texto aponta que

"a abertura de ruas para loteamentos sem o cuidado imediato da instalação de sistemas adequados de drenagem de águas de superfície leva, inevitavelmente, à formação de sulcos pioneiros que se transformarão em novas e problemáticas boçorocas" (PREFEITURA MUNICIPAL DE FRANCA, [1971?e]:4).

Desta forma, propunha-se como imprescindível, sob pena de inutilidade do Plano Diretor,

“a) proibição imediata de novos loteamentos e a suspensão dos processos solicitando a aprovação de novos loteamentos já em tramitação na Prefeitura, até que seja aprovada a Lei do Plano Diretor Físico;

b) aprovação ipsis littere dos dispositivos da Lei do Plano Diretor Físico, que estabelecem os limites do Perímetro Urbano e definem os limites da Área de Expansão Urbana; c) aprovação integral dos dispositivos da Lei do Plano Diretor Físico, que estabelecem a exigência de guias, sarjetas e drenagem de águas pluviais ou outras medidas que os órgãos técnicos da Prefeitura julgarem necessários em função da forte tendência à erosão nas áreas do sítio urbano de Franca e de sua circunvizinhança" (PREFEITURA MUNICIPAL DE FRANCA, [1971?e]:4).

Além destes pontos, também se apresentava como indispensável a

"necessidade de aprovação sem alteração dos dispositivos da Lei do Plano Diretor Físico que tratam do Zoneamento de Uso e das Diferenciações Zonais para Edificar nos Lotes. As taxas e os índices de 


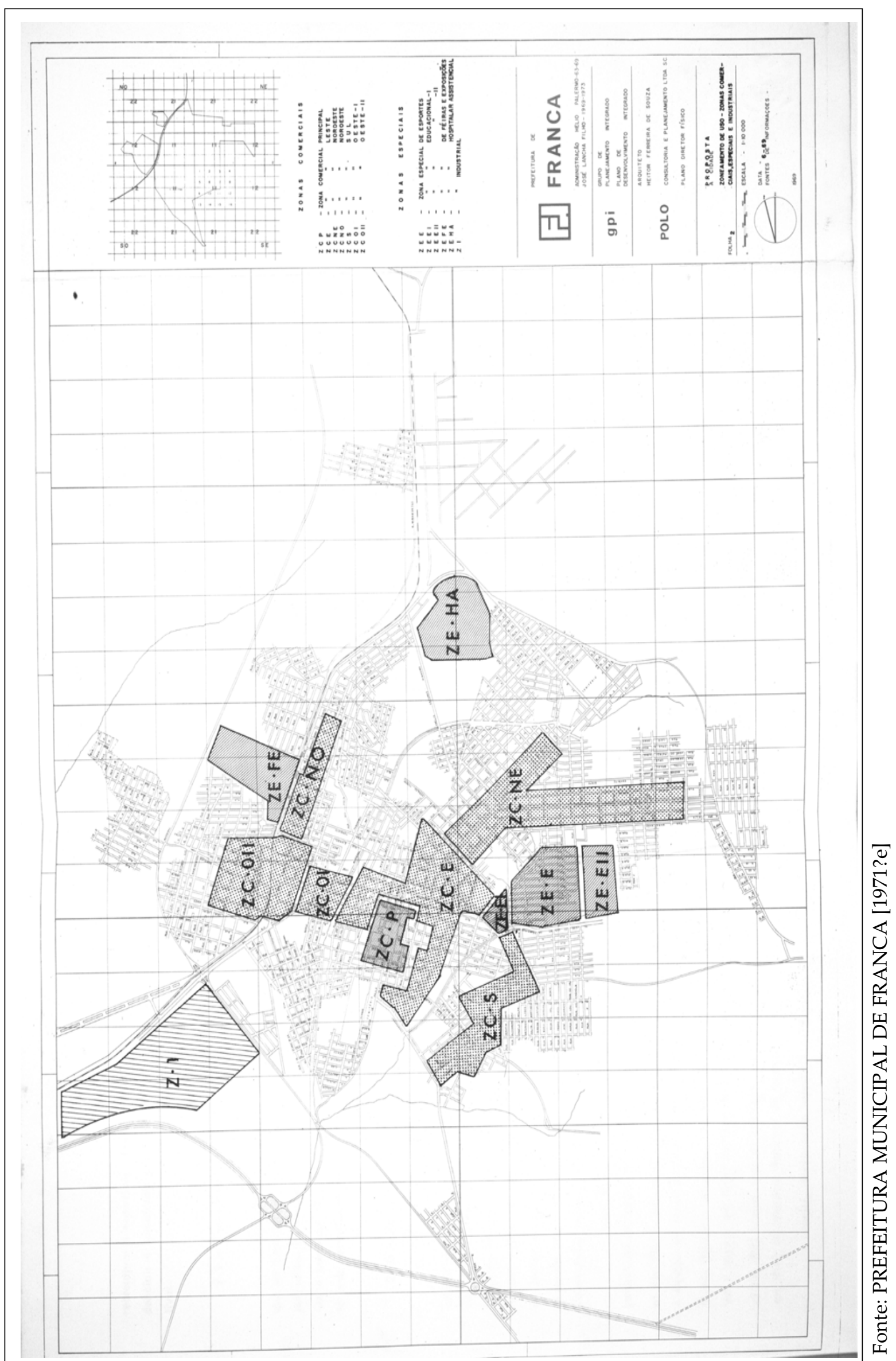

Mapa 2. Zoneamento de uso - Zonas comerciais, especiais e industriais. 
ocupação estabelecidos foram estudados de modo a induzir uma densificação racional da cidade" (PREFEITURA MUNICIPAL DE FRANCA, [1971?e]:5).

Ou seja, as propostas eram vistas como imprescindíveis e não deveriam ser modificadas em hipótese alguma, nem mesmo pela Câmara Municipal, refletindo traços autoritários e fornecendo uma característica impositiva ao Plano, que pode ser adjetivada como tecnocrática, pois não abre espaço para qualquer questionamento da proposta, vista portanto como tecnicamente perfeita e inquestionável, impermeável ao debate.

Para modificar o quadro diagnosticado da ocupação e uso do solo da cidade, propunha-se que, com base em critérios como densidades de ocupação, padrão das edificações, características topográficas do sítio natural e processo da ocupação urbana fosse possível subdividir a área urbana em cinco diferentes zonas: o centro, o bairro da Estação, a Cidade Nova, os loteamentos situados depois da estação ferroviária e a Santa Cruz. O objetivo seria facilitar e sistematizar a análise do espaço urbano e seus componentes.

Vê-se aqui, uma clara manifestação quanto à pretensa "racionalidade técnica" do trabalho de planejamento desenvolvido, onde

"qualquer alteração nas taxas de ocupação previstas ou no zoneamento preconizado provocará o desmoronamento de toda a estrutura da Política de Desenvolvimento Físico, fundamentada neste trabalho com base em mais de um ano de estudos minuciosos" (PREFEITURA MUNICIPAL DE FRANCA, [1971?e]:5).

Segundo o Diagnóstico, havia também uma urgência para:

a) "Hierarquizar o tráfego mediante a determinação precisa das vias primárias e secundárias, bem como o estabelecimento dos acessos, das saídas e das direções.

b) Estabelecer com nitidez a interligação entre as rodovias e os sistemas primário e entre estes e os secundários.

c) Identificar e estabelecer as ligações inter-bairros sem que o tráfego cruze o centro da cidade.

d) Criar os sistemas destinados aos pedestres" (PREFEITURA MUNICIPAL DE FRANCA, [1971?a]:112).

Com isso, estariam justificadas as intervenções no sistema viário, que era considerado antiquado e insuficiente para atender as demandas de expansão da cidade e de suas atividades econômicas.

Tomando-se como base as propostas, pode-se dizer que o Diagnóstico nada tinha de irreal, nem era apenas uma extensiva compilação de dados pouco efetiva, em contraposição à crítica que os Planos financiados pelo SERFHAU, por sua concepção tecnocrática e autoritária, não faziam a leitura adequada da realidade, presente em vários planos do período, como no PUB de São Paulo e no Plano Doxiadis do Rio de Janeiro, como vários estudos demonstram.

Primeiro, porque aquilo que o Diagnóstico aponta, estava calcado numa análise situacional que diagnosticava corretamente os principais entraves para o tipo de desenvolvimento econômico que o poder público e o setor empresarial calçadista desejavam: 
- um sistema viário moderno, que permitisse a rápida circulação do automóvel e das mercadorias produzidas pela indústria;

- a melhoria da região central, onde se instalava o comércio principal;

- a expansão horizontal da cidade, que prejudicava o fornecimento de infraestrutura e serviços, bem como a capacidade de investimento e manutenção da cidade pela prefeitura;

- a implantação de um distrito industrial moderno, segregando as indústrias consideradas incomodas em um local distante das moradias e, ao mesmo tempo, propiciasse ganhos de escala na produção, já que a indústria coureirocalçadista estava disseminada por toda a cidade, inclusive nas regiões centrais e começavam a ser alvo de reclamações da vizinhança (FERREIRA, 1989).

Especificamente no caso do sistema viário, a adoção impositiva nos novos parcelamentos do solo a partir de 1977, com base nas dimensões exigidas pela Lei do Plano Diretor Físico, de vias principais hierarquizadas com largura de 32 metros, às expensas dos empreendedores, foi suficiente para o surgimento de novas e importantes vias de circulação intra-urbanas, sem quaisquer ônus para o Município em desapropriações, como nas avenidas São Vicente, Chafi Facuri, Orlando Dompieri, Abrahão Brickman, prolongamento da Brasil, dentre outras, como se pode verificar analisando os processos de aprovação dos empreendimentos imobiliários que deram origem às mesmas junto ao Cadastro Físico da Prefeitura. Além disso, os procedimentos de aprovação de loteamentos passaram a exigir o fornecimento de diretrizes prévias aos empreendedores e de caução para garantir as obras de infra-estrutura de responsabilidade dos empreendedores ${ }^{4}$.

Os aspectos que não foram implementados ou, ao contrário, seguiram em direção oposta ao diagnosticado, como a expansão da cidade, onde a tentativa de bloquear novos loteamentos não prosperou por muito tempo, podem ser debitados à conta de uma visão dos dirigentes municipais e principalmente do setor empresarial calçadista, que tinha na política de expansão territorial da cidade sem grandes limitações preservadas suas possibilidades de investimentos em terrenos, construção e implantação generalizada de fábricas pela cidade, expansão que poderia continuar ocorrendo sem necessidade de transferência para um outro local enquanto a administração não viabilizava o Distrito Industrial.

As palavras dos ex-prefeitos Ary Balieiro e Maurício Sandoval Ribeiro são elucidativas neste aspecto, quando Ary afirma que Franca, em seu mandato, continuou "com a sua vocação de crescimento horizontal", e de Maurício Sandoval Ribeiro, que diz:

"eu lembro de uma frase do Fernando, logo no começo da administração, ele disse, ora Maurício, o governo estadual e federal não tem dinheiro para construir casa para todo mundo, eu falei qual a solução, a solução é nós abrirmos o maior número possível de loteamentos, porquê aí entra a lei da oferta e da procura, tendo bastante lote o preço vai cair e a pessoa mais humilde vai ter condições de comprar em suaves prestações mensais e ele vai construir sua casinha e nós não vamos ficar dependendo só do governo estadual e federal, e imediatamente eu concordei" ${ }^{5}$,

\footnotetext{
${ }^{4}$ Ver a respeito CHIQUITO, 2006.

${ }^{5}$ A frase de Maurício, oriundo de tradicional família de políticos da cidade, de proprietários de terra com atividades ligadas à cafeicultura, foi proferida em entrevista gravada fornecida ao autor em 28/01/2005.
} 


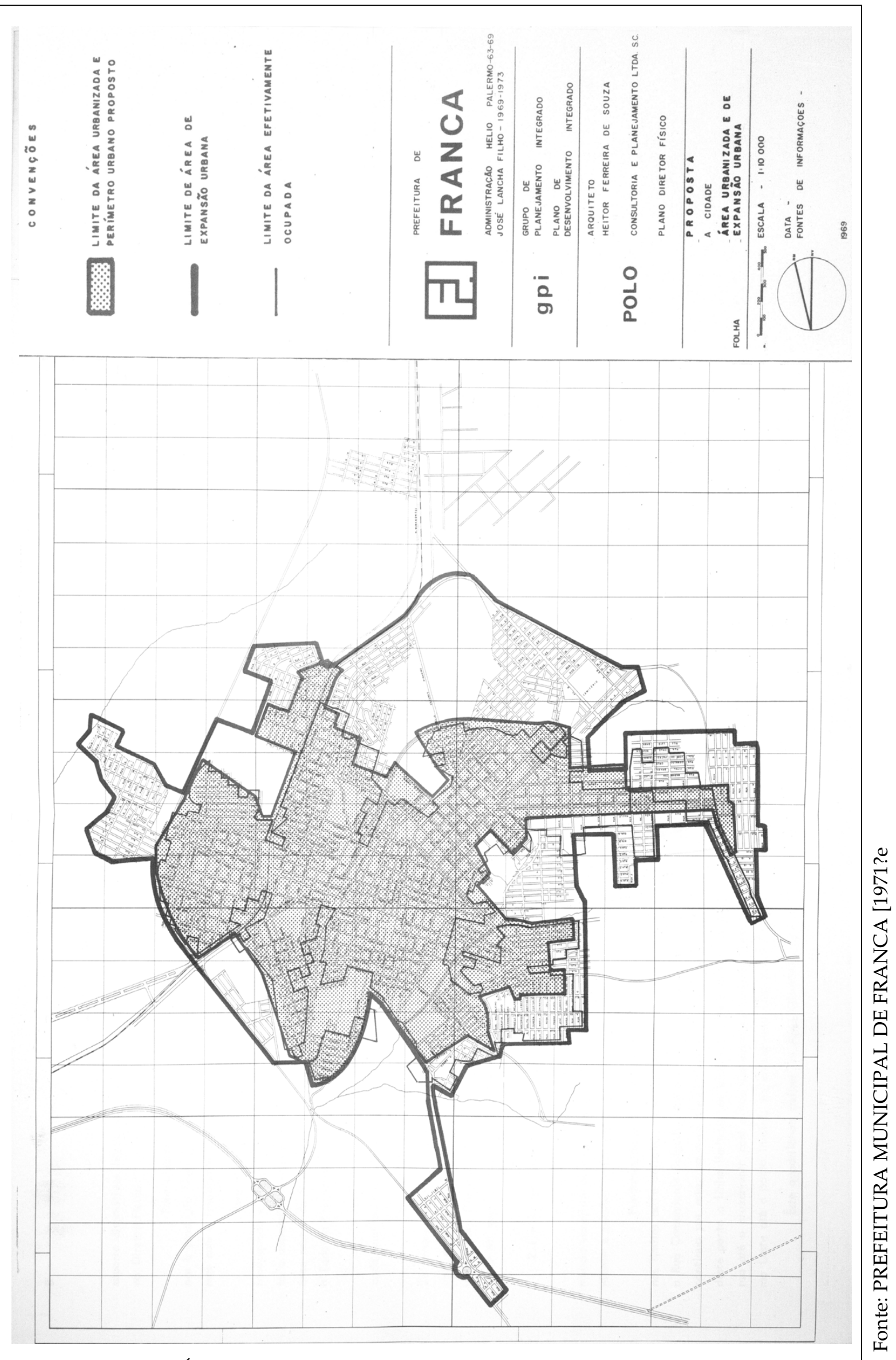

Mapa 3. Mapa da Área Urbanizada e de Expansão Urbana proposta pelo Plano. 
ou seja, isto é importante ressaltar, que esta visão da cidade como tendo uma vocação de horizontalidade, de abertura para novos loteamentos como contraponto às favelas, é um discurso que permeia as explicações sobre a questão pelos dirigentes locais ${ }^{6}$.

\section{AS PROPOSTAS DO PLANO DIRETOR FÍSICO: O CONTROLE DA EXPANSÃO URBANA E O ZONEAMENTO DE USO E OCUPAÇÃO DO SOLO}

A partir de uma introdução aos temas considerados prioritários, o trabalho realizado pelo GPI procura demonstrar didaticamente as propostas físicas para a cidade. O mapa da Área Urbanizada e de Expansão Urbana apresenta a área já urbanizada e para onde deveria ocorrer a expansão urbana, definindo o limite do perímetro urbano, pouco ampliado além das regiões já efetivamente ocupadas ou em processo de ocupação.

Verificaremos, mais adiante, que a expansão urbana não respeitou os limites impostos pela proposta, ao contrário, em poucos anos estava muito superior aos mesmos, bem como a recomendação para não aprovar novos loteamentos vigorou por pouco tempo.

Definia-se também a instituição de 24 zonas de uso do solo, agrupadas por uso, semelhanças e compatibilidades. Até então, o município carecia de qualquer tipo de zoneamento específico ou de controles sobre o uso e ocupação do espaço urbano, a não ser algumas regulamentações gerais para aprovar loteamentos, como aquelas previstas na lei n. 1095, de 21 de dezembro de 1962 e n. 1285, de 23 dezembro de 1964, e do Código de Edificações, provavelmente elaborado pelo GPI e transformado na lei 1647, de 2 de setembro de 1968. As únicas formas de controle sobre a produção de edificações e o licenciamento de atividades econômicas eram a aprovação de plantas e a emissão de licenças para construir e para funcionamento de atividades, de acordo com o código de obras e o código tributário vigentes, não havendo restrições zonais de uso ou ocupação do solo.

De acordo com a proposta, o setor primário, na zona rural, estava destinado à produção de alimentos; o setor secundário tinha como proposta a localização de uma área específica, o futuro distrito industrial; e para o comércio e prestação de serviços, são indicadas diversas áreas, assim como para as residências, indicando um procedimento de setorização das atividades urbanas dentro dos princípios defendidos à época pelos planejadores modernistas brasileiros. Além destas zonas, definiram-se também áreas de proteção ambiental e áreas verdes, principalmente as áreas constituídas pelas voçorocas.

Para a Zona Comercial Principal, diferentemente das outras, havia uma proposta bastante inovadora para uma cidade do interior: o bloqueio de um grande quadrilátero, que definiria um anel giratório para os veículos. No seu interior, não seria permitido o ingresso de veículos, a não ser em condições excepcionais, como ambulâncias, bombeiros, transporte de móveis e outros, cuja regulamentação seria feita. Desta maneira,

\footnotetext{
${ }^{6}$ A frase de Ary foi proferida em entrevista gravada fornecida ao autor em 19/01/2005. É importante lembrar que Ary Balieiro, antes de assumir a Secretaria de Planejamento, foi empresário-construtor de diversos empreendimentos imobiliários, como conjuntos habitacionais do BNH (Jardim Pedreiras, de 1969 e Jardim do Éden, de 1975), assim como de loteamentos residenciais (Jardim do Líbano, de 1980 e Jardim Portinari, de 1981). Ver a respeito FUENTES, 2006.
} 
"com base nesta orientação a área central da cidade poderá ser totalmente reestruturada nos seus aspectos urbanos: infraestrutura, equipamentos, paisagens, estética, etc. Assim, poderá transformar-se numa área onde existiriam condições mais adequadas para os pedestres, sem os riscos e inconvenientes da presença da circulação motorizada". (PREFEITURA MUNICIPAL DE FRANCA [1971?e]:9)

Esta zona, portanto, seria reestruturada, admitindo-se acesso aos estabelecimentos bancários, comércio e residencial plurihabitacional. A proposta estava atualizada e vinculada ao debate urbanístico vigente naquele período histórico, quando as idéias de renovação dos cascos históricos centrais das cidades começam a se tornar uma tendência internacional nas práticas de planejamento, principalmente pela difusão de experiências como a de Bolonha, na Itália, do desenvolvimento de parceria público/privado nas grandes cidades norte-americanas, como Boston, Saint Louis, Philadephia e Louisville e, principalmente, as propostas desenvolvidas pelo IPPUC para Curitiba, no Brasil (VARGAS e CASTILHO, 2006).

As demais zonas comerciais foram situadas nos corredores de circulação existentes, em especial junto às avenidas Presidente Vargas, Brasil e rua da Estação, onde já havia uma concentração deste tipo de atividade. As zonas especiais Educacionais foram previstas com base na construção dos novos prédios para as faculdades municipais de Economia e Direito (então em projeto), visando assumir características de um campus universitário.

A zona especial de Esportes deveria receber o novo estádio de futebol, que a A.A. Francana estava dando início, mas que foi encampada pelo poder público municipal ao final do governo de Hélio. A zona especial de feiras e exposições foi prevista na região onde já existia o parque estadual Fernando Costa, utilizado como local para exposições ligadas à pecuária e agricultura, onde deveriam se concentrar hotéis e atividades turísticas.

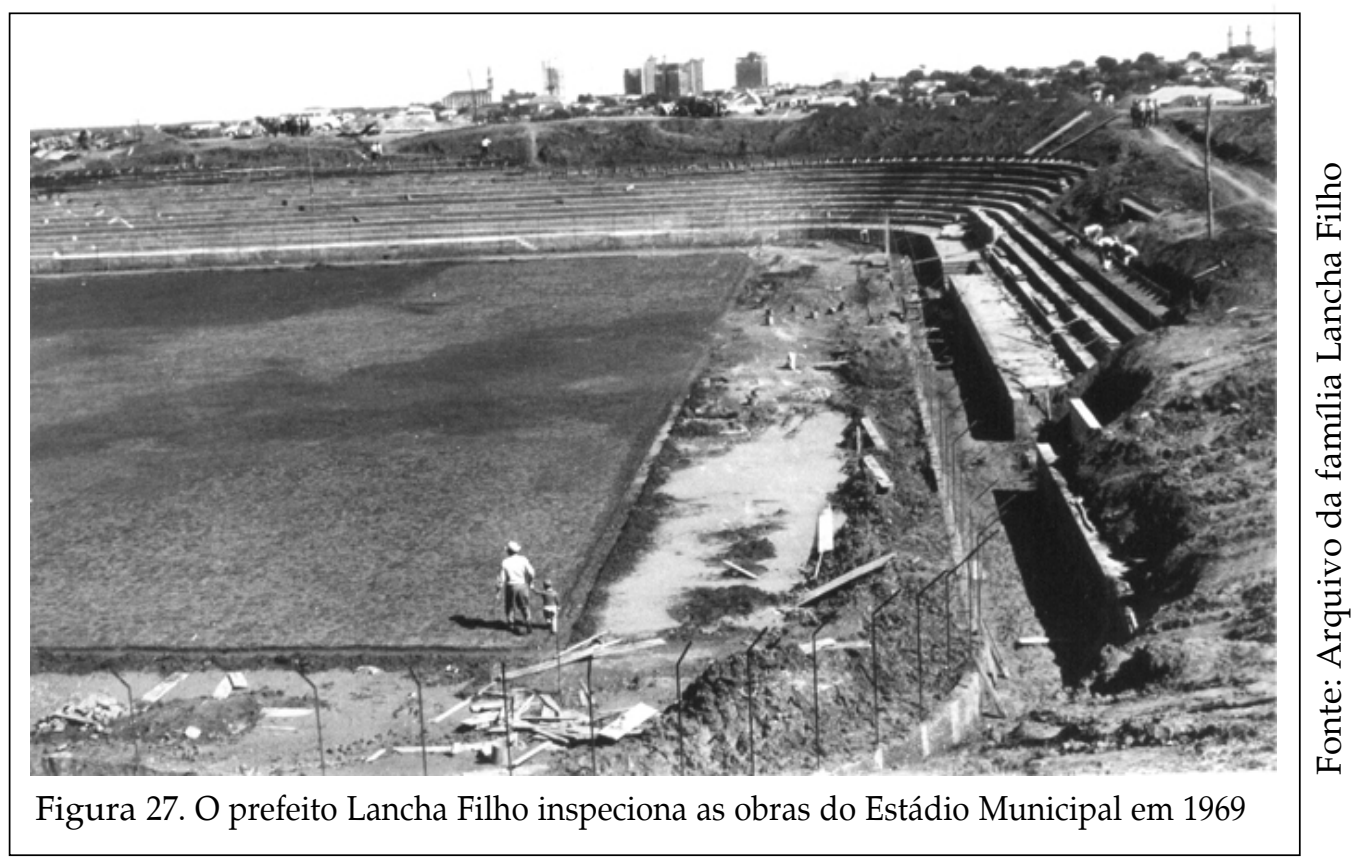




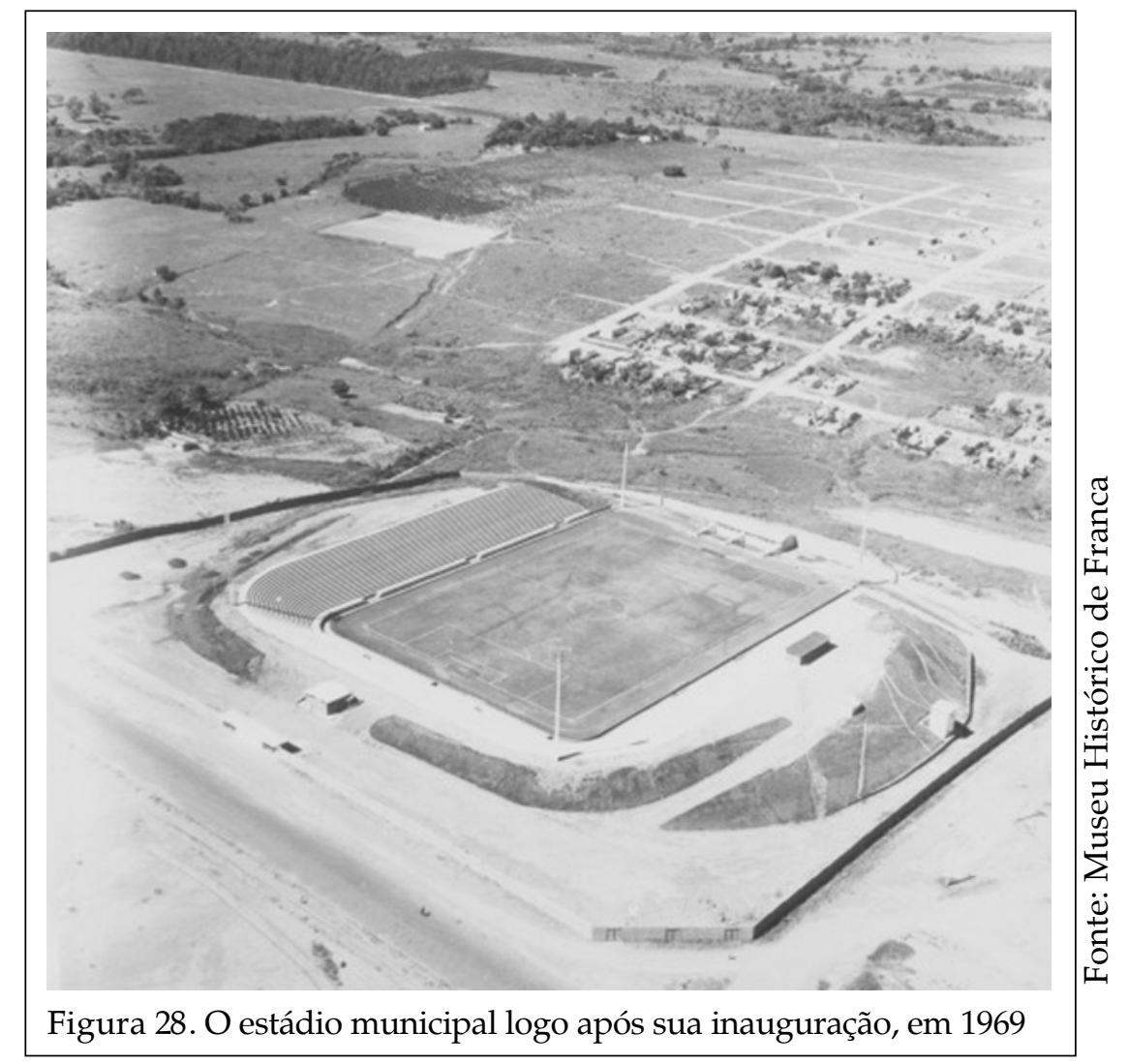

Quanto às zonas residenciais, foram previstas dez, caracterizadas como sendo de alta densidade (350 hab/ha), média (200/ha) e baixa (100 hab/ha), estas últimas situadas nas periferias da cidade. Em três delas, foram estabelecidos cinturões especiais de proteção, em torno dos hospitais, visando preservar estas instituições da perturbação pelo tráfego de veículos, poluição atmosférica, ruídos e vibrações. Os mapas de zoneamento do uso apresentam os perímetros das diversas zonas residenciais e suas densidades previstas.

Pode-se inferir na proposta do zoneamento, além de uma preocupação com a capacidade da prefeitura atender as demandas por infra-infraestrutura, a evidente incorporação de propostas da própria prefeitura em andamento, como a instalação dos novos prédios das faculdades municipais de Direito e Economia, assim como do estádio municipal de futebol, demonstrando que a leitura da cidade levava em conta idéias locais e não apenas da empresa de consultoria. 
AS PROPOSTAS DO PLANO DIRETOR FÍSICO: MODERNIZAÇÃO DA CIRCULAÇÃO E DO SISTEMA VIÁRIO

Quanto ao sistema viário, circulatório e hierarquização das vias, a Política de Desenvolvimento Físico aponta como urgente a necessidade de se melhorar a circulação de veículos,

\footnotetext{
"quer através de cirurgia urbana em pequenos trechos onde este processo seja viável com mais ênfase, quer através da abertura de novas avenidas que facilitem a ligação entre bairros distantes". (PREFEITURA MUNICIPAL DE FRANCA [1971?e]:15)
}

A proposta previa ainda a construção de duas passagens sobre os trilhos da estrada de ferro, relacionadas a uma possível e futura retirada da ferrovia, que já estava em situação de decadência. Além disso, recomendava-se a construção de dois novos acessos rodoviários à cidade, pela estrada Franca-Araxá e estrada FrancaBarretos. Também uma nova estação rodoviária deveria ser implantada, aproveitandose a voçoroca de Santa Rita, ao lado da nova avenida marginal do córrego do Cubatão.

A proposta de hierarquização do sistema viário define as vias principais: a avenida marginal do córrego dos Bagres, avenida Getúlio Vargas, rua Paraná, avenida José Negreiros Sayão (posteriormente renomeada como Sete de Setembro), avenida marginal do córrego Cubatão, avenida Champagnat, avenida Major Nicácio, e outras de menor expressão.

Para implantar o anel giratório junto ao centro da cidade, propõe-se o remanejamento das quadras situadas dentro do quadrilátero formado pelas ruas Campos Salles, General Carneiro, Ouvidor Freire e Comandante Salgado. Para isso, seria preciso também bloquear a passagem de veículos em acessos controlados, que somente seriam abertos no período noturno para limpeza, mudanças, carga e descarga, bem como para acesso de bombeiros, ambulâncias e, valorizando a importância política da igreja católica na cidade, de "veículos que conduzam passageiros à igreja matriz". (PREFEITURA MUNICIPAL DE FRANCA [1971?e]:20)

A proposta previa ainda a necessidade de promover a instalação de garagens comerciais, repavimentar as vias do anel, homogeneizar seus passeios e revesti-los com elementos paisagísticos e decorativos, de maneira que o local se tornasse mais atraente a seus usuários.

Outro aspecto levantado quanto ao sistema viário foi o disciplinamento dos cruzamentos, através de praças rotatórias ou passagens em desnível, para reduzir os pontos de conflito no tráfego urbano. Os pontos sugeridos, constantes no mapa do sistema viário, são:

- avenida marginal ao córrego do Cubatão com Champagnat, Saldanha Marinho e Major Nicácio;

- avenida Major Nicácio com avenida Getúlio Vargas e Brasil com Getúlio Vargas;

- avenida marginal do córrego do Bagres com ruas Batatais, General Telles, General Carneiro, General Osório, Evangelista de Lima, Afonso Pena, Amália Antunes Pinheiro; 
- avenida marginal do córrego dos Bagres com avenida Getúlio Vargas;

- rua G com rua São Benedito;

- cruzamento da rua Evangelista de Lima com a rua Carlos de Vilhena

- cruzamento da avenida Rio Branco com rua Cássia

Aqui também transparece a preocupação de incorporar projetos em andamento, como das avenidas marginais aos córregos dos Bagres e do Cubatão. Além disso, as demais propostas viárias se apresentam viáveis, não demandando grandes obras ou desapropriações, além de atender todas as regiões urbanizadas, não evidenciando qualquer direcionamento ou ênfase em locais específicos para a expansão da cidade.

\section{AS PROPOSTAS DO PLANO DIRETOR FÍSICO: EXPANSÃO DOS EQUIPAMENTOS PÚBLICOS}

A Política de Desenvolvimento Físico estabelecia ainda uma priorização em relação à produção de equipamentos comunitários e infra-estrutura, conforme apresentado no mapa Áreas Urbanizadas e Prioridades de Urbanização, indicadas em termos de primeira a quarta prioridade. Propõe-se, dentre outros aspectos, a construção de estação de tratamento de esgotos sanitário e industriais, emissários para captação de esgotos, novos reservatórios de acumulação de água potável, expansão e modernização das redes de energia elétrica e iluminação pública, galerias pluviais, aterro sanitário, modernização dos serviços de comunicação e telefonia, e uma infra-estrutura de abastecimento alimentar, através de sete células ou pequenos mercados distritais, conforme apresentado no Mapa de Localização de Núcleos de Abastecimento Alimentar. Ou seja, além dos aspectos físicos, o planejamento integrado, de acordo com a metodologia proposta pelo SERFHAU, propugnava uma articulação com os demais aspectos econômicos e sociais da cidade, incluindo educação e saúde.

Em função desta integração do planejamento, recomendava-se a reserva de uma área para instalar as faculdades municipais, em área próxima à avenida Major Nicácio e à marginal do córrego do Cubatão, onde já se preparava a instalação das faculdades municipais. Propõe-se ainda a construção de quatro novas escolas municipais, todas localizadas em regiões periféricas da cidade.

Outro aspecto apontado é a necessidade de implantar vinte e sete parques infantis, por toda a cidade, e três postos de puericultura, visando atendimento de saúde infantil, na Vila Nova, Vila Santa Rita e bairro da Capelinha, também localizados nas áreas periféricas da cidade. Todos os equipamentos citados estão apontados no Mapa Localização de Parques Infantis, Postos de Puericultura e Escolas, inclusive com sua respectiva priorização.

Recomenda-se também atenção especial às vias não pavimentadas e à conservação da pavimentação existente, assim como o emplacamento de ruas e a arborização de vias. Ao final, propõe-se também utilizar o potencial paisagístico e urbanístico das áreas das voçorocas, transformando-as em parques e jardins públicos, em especial a das Maritacas, bem como a construção de um lago artificial no vale dos Bagres, criando um ponto de atração e lazer próximo ao centro da cidade, propostas apresentadas no Mapa de Áreas Verdes para Fins Paisagísticos, incorporando basicamente aquelas as proposituras e considerações dos estudos de Aziz Ab'Saber. 


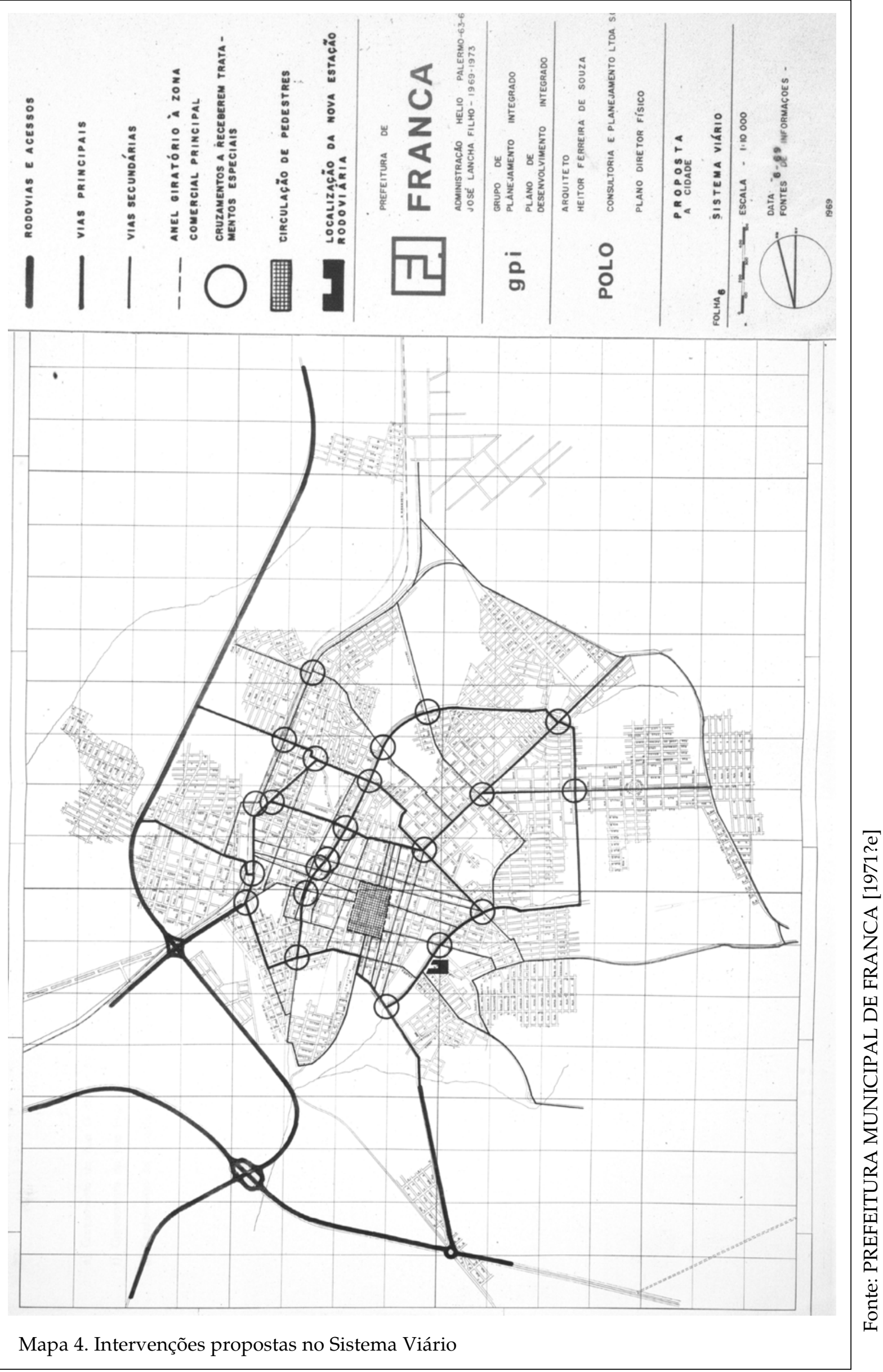


Propunha-se também, dentro de uma linha de diversificação do desenvolvimento econômico, de estabelecer incentivo ao turismo através da criação de novos clubes nas represas das barragens das usinas hidrelétricas de Estreito e Peixoto. Além disso, deveria ser estudada a localização de um parque destinado à instalação da feira industrial, que promoveria as indústrias locais e atrairia fluxo de turistas à cidade, vista como uma necessidade premente para acelerar o desenvolvimento do parque industrial calçadista. É o embrião da idéia de uma feira da indústria local que se transformaria na Francal, hoje uma das mais importantes feiras calçadistas da América Latina.

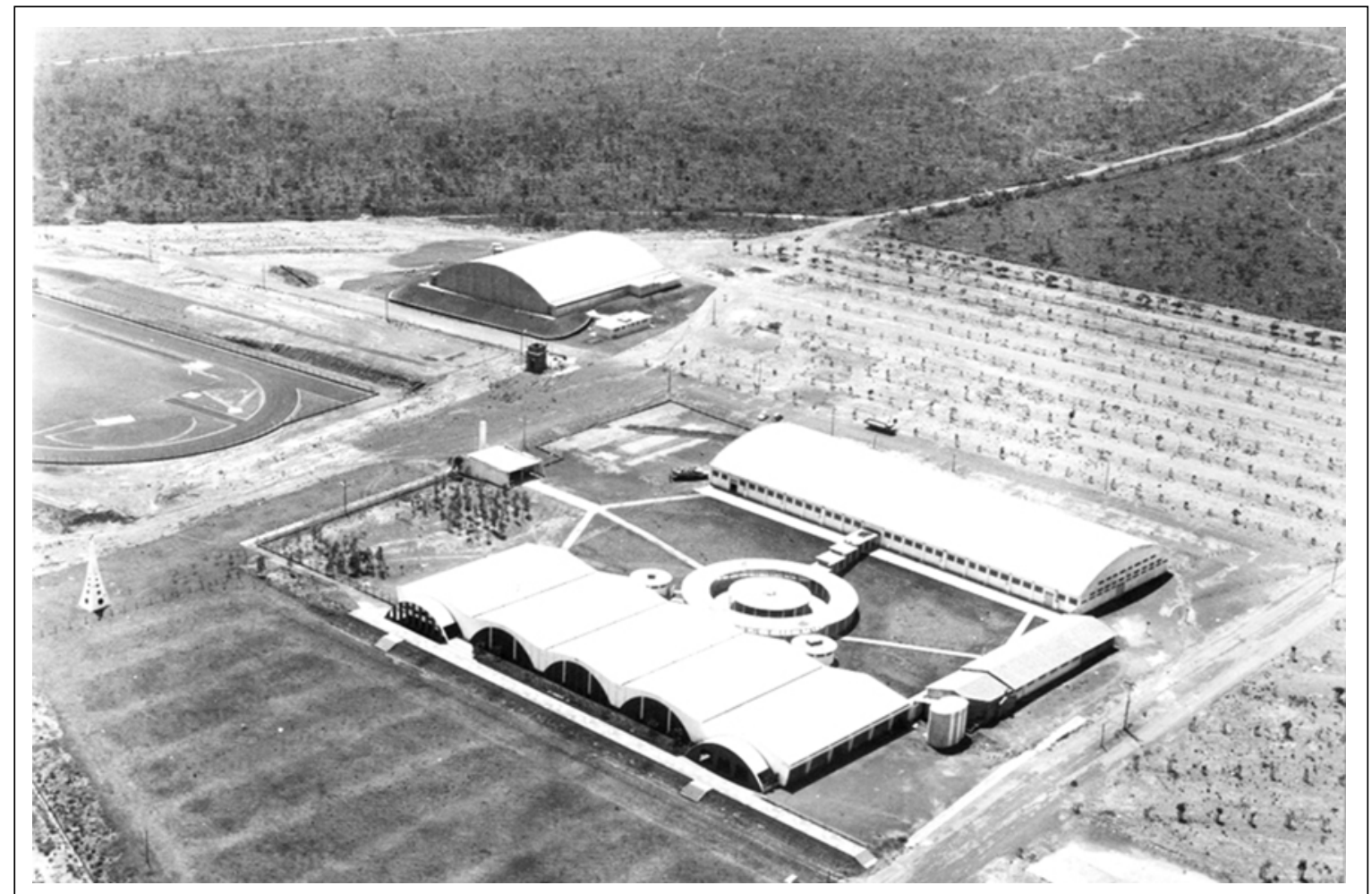

Figura 29. Os pavilhões recém construídos da Francal em meados dos anos 1970.

O conjunto das propostas pode ser considerado equilibrado e integrado: preocupa-se com o centro da cidade e com a sua modernização e, ao mesmo tempo, com a criação de equipamentos públicos e fornecimento de infra-estrutura para as regiões periféricas em processo de ocupação. Ao mesmo tempo que propõe uma contenção radical da expansão urbana, define a criação de um poderoso pólo indutor de desenvolvimento, o distrito industrial. Também as áreas já ocupadas são objeto de tratamento urbanístico e controle, através do zoneamento de uso que define com clareza uma ocupação "racional" para os espaços já urbanizados e, ao mesmo tempo, exige a implantação de novos equipamentos de educação, lazer e outros, permitindo um adensamento das áreas já ocupadas ou em processo de ocupação. Também a política de ampliação do sistema viário está calcada na idéia da pedestrianização do centro e na ampliação de vias já existentes, reduzindo despesas com grandes desapropriações.

Ou seja, as propostas não eram inexeqüíveis nem estavam em descompasso com a realidade e com os interesses dos setores políticos dominantes, em especial o industrial. A não ser na questão da expansão horizontal e da localização industrial. 


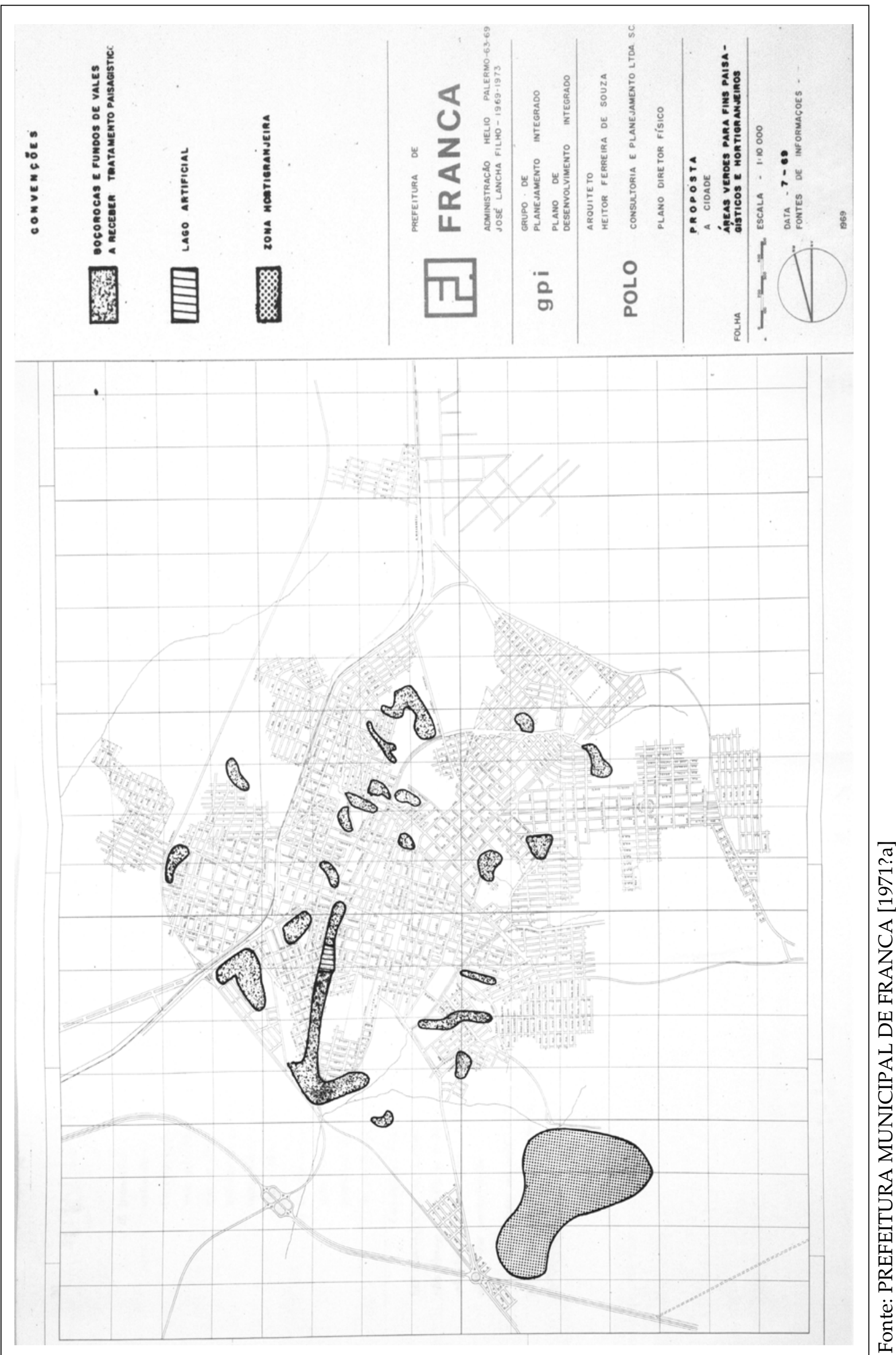

Mapa 5. Áreas para fins paisagísticos e produção hortigranjeira. 
O volume que traz o projeto de lei do Plano Diretor Físico segue uma espécie de padrão modelo dos projetos de lei elaborados pela empresa GPI. Verificamos entre os projetos de lei de Franca e de Votuporanga (SP), que foram desenvolvidos quase ao mesmo tempo pelo GPI, aspectos formais de elaboração legislativa bastante próximos. O que diferencia o projeto de Franca é o conjunto de programas concretos de ação contidos nele, principalmente de obras a serem realizadas. Segundo Cadaval, o projeto de lei foi sistematizado por Diógenes de Arruda Câmara ${ }^{7}$.

Além dos aspectos de identificação e instrumentos de controle de zonas de uso do solo, de regras físicas e administrativas para a realização de loteamentos e edificações particulares, incluindo dimensões de vias e de áreas públicas para usos institucionais e verdes, de emplacamento de vias (proposta que também foi realizada, todas as edificações urbanas foram renumeradas a partir da reorganização do cadastro, no governo de Lancha Filho) e outros aspectos administrativos ligados à gestão espacial urbana, há no projeto de lei de Franca propostas concretas de intervenção física no espaço da cidade, para além das tradicionais diretrizes e normativas urbanísticas de controle do uso do solo usuais neste tipo de projeto de lei.

São previstos 442 artigos, distribuídos em 20 capítulos, que estão dispostos na seguinte sequência:

- Disposições Gerais

- Do Plano Diretor Físico

- Do Sistema de Referência Cadastral

- Da Divisão Territorial em Áreas Integradas

- Do Abairramento

- Do Sistema de Estradas e Caminhos Municipais

- Do Sistema Viário Urbano

- Do Alinhamento e do Nivelamento

- Do Zoneamento de Uso dos Terrenos, Quadras, Lotes, Edificações e Compartimentos

- Da Urbanização de Terrenos

- Das Áreas Públicas Paisagísticas e da Preservação da Paisagem Natural

- Do Planejamento ou Remanejamento de Quadras, do Desmembramento ou Reagrupamento de Lotes e do Projetamento de Conjuntos Residenciais

- Das Edificações nos Lotes

- Da Estética dos Logradouros na Paisagem Urbana

\footnotetext{
${ }^{7}$ Em depoimento, Cadaval diz que a sistematização do projeto de lei foi obra de Diógenes. Heitor, em seu depoimento, afirma que Diógenes tinha grande experiência na elaboração de projetos de lei por ter sido deputado, geralmente assumindo esta tarefa nos trabalhos do GPI.
} 
- Do Sistema de Circulação e do Estacionamento

- Da Renovação Urbanística da Cidade de Franca

- Da Implantação do Plano Diretor Físico

- Da Fiscalização da Prefeitura

- Das Infrações e Penalidades

- Disposições Finais e Transitórias (PREFEITURA MUNICIPAL DE FRANCA [1971?d]:3)

O capítulo inicial, que trata das Disposições Gerais, institui o Plano Diretor Físico do Município de Franca como o ordenador e disciplinador do seu desenvolvimento, de forma integrada e harmônica, estabelecendo ainda a obrigatoriedade de uma estrutura cartográfica para a representação territorial. O capítulo II, que trata do Plano Diretor Físico, estabelece as finalidades do Plano: assegurar o desenvolvimento físico racional, harmônico e estético das estruturas urbanas e rurais, propiciando estruturas urbanas capazes de atender plenamente as funções de habitar, trabalhar, circular e recrear, para proporcionar à população ambiente urbano equilibrado e sadio. Observa-se, neste capítulo, a clara influência no plano do discurso, dos conceitos estabelecidos pelo planejamento modernista definidos na Carta de Atenas. O capítulo III institui um Sistema de Referência Cadastral, por meio de um sistema cartesiano de coordenadas ortogonais, constituindo quadrantes divididos em quadrículas, com a finalidade de permitir a identificação dos elementos componentes de sua configuração física, e a representação do cadastro físico da estrutura e dos equipamentos urbanos. Com estes elementos, o Plano estabelece a obrigatoriedade e a necessidade de implantação e um permanente processo de manutenção e atualização de seu cadastro físico, enquanto elemento gerador de informações para o planejamento da cidade e a cobrança de tributos municipais.

A Divisão Territorial em Áreas Integradas está prevista no capítulo IV, dividindo o território do município em três áreas distintas, a urbana, a de expansão urbana e a rural. A área urbana compreende os terrenos com edificações contíguas servidas, em 6 de janeiro de 1969, por dois melhoramentos públicos, como meio fio, pavimentação, rede de água potável, rede de esgotos sanitários, rede de iluminação pública ou ainda escola primária ou posto de saúde situado no máximo a três quilômetros do imóvel considerado. Através de descrição e de mapa, fixa-se uma área urbana e de expansão urbana, ficando o restante do território como área rural. $\mathrm{O}$ capítulo $\mathrm{V}$ define um Abairramento, com dez bairros: Centro, Estação, Vila Nova, Cidade Nova, Capelinha, Vila Monteiro, Santa Rita, São José, Santa Cruz e Consolação. A utilidade do abairramento está descrita como necessária para assegurar o ordenamento e disciplinamento da localização e dimensionamento dos equipamentos comunitários. Através da definição de uma zona urbana e de expansão urbana e sua divisão territorial como unidade para o planejamento, pressupunha-se garantir uma racionalidade para a ocupação do espaço urbano e a aplicação dos recursos públicos e investimentos de forma a atender as necessidades da população.

No capítulo VI, que trata do Sistema de Estradas e Caminhos Municipais, o objetivo é assegurar o livre trânsito público na área rural do município, o escoamento 
da produção e o acesso às glebas e propriedades. O capítulo estabelece um conjunto de regras destinado a identificar as vias e suas especificações técnicas. Já em relação ao Sistema Viário Urbano, objeto do capítulo VII, o objetivo é hierarquizar as vias de maneira a compatibiliza-las com as funções que deveriam desempenhar na estrutura física, compreendendo vias de trânsito rápido, principais ou preferenciais, secundárias e locais. O capítulo define com detalhe as especificações técnicas das vias, como larguras, declividades máximas e concordâncias nos cruzamentos. O capítulo VIII complementa o anterior, estabelecendo regras para o Alinhamento e Nivelamento das vias públicas, com a finalidade de regular a implantação das vias e das construções em consonância com a respectiva via pública. O capítulo XV complementa o assunto, estabelecendo o Sistema de Circulação e Estacionamento. Basicamente, ele fixa diretrizes para o ordenamento e disciplinamento do sistema de circulação e estacionamento, como sinalização, mãos de vias, itinerários do transporte coletivo, proibições de estacionamento e circulação, etc. Com estes elementos, a Lei do Plano Diretor Físico condensa a legislação sobre o sistema viário, visto como essencial para o desenvolvimento da cidade.

O capítulo IX define o Zoneamento de Uso dos Terrenos, com a finalidade de agrupar usos idênticos, análogos e compatíveis entre si, de modo a impedir conflitos entre as atividades sociais e econômicas, de forma a permitir o desenvolvimento racional dos aglomerados urbanos. Para isso, os terrenos poderão ter utilização residencial, cultural, recreativa, assistencial, institucional, prestação de serviços, comercial, bancária e industrial. Define-se um conjunto de 24 zonas de uso, descritas minuciosamente em planta e no texto da lei. Para cada uma delas, há uma descrição dos usos permitidos e permissíveis. Institui-se assim, pela primeira vez, um zoneamento de uso e ocupação do solo na cidade, buscando "especializar" algumas regiões da cidade, que era ocupada de forma "espontânea", com bairros residenciais da população mais pobre localizados nos altos da Capelinha e após a estrada de ferro, o comércio concentrado no centro, na Estação e na Cidade Nova, e a indústria esparramada por toda cidade.

O capítulo $X$ trata de urbanização de terrenos, objetivando assegurar que o planejamento e a urbanização de terrenos assegurassem disposição, forma, dimensionamento e conexões equilibradas dos espaços destinados às funções urbanas, como habitar, circular, recrear e trabalhar. Para tanto, estabelece requisitos e padrões urbanísticos decorrentes dos modernos princípios a serem atendidos, como comprimento e largura de quadras, dimensões mínimas para lotes e outras especificações. Há uma seção específica estabelecendo critérios para o planejamento de terrenos para fins populares, reduzindo o grau de exigências e de dimensionamento, em zonas residenciais específicas. Também o planejamento de terrenos para fins urbanos na área rural tem previsões e regras urbanísticas específicas para sua urbanização. Este capítulo estipula ainda as regras burocráticas referentes ao processo de tramitação para aprovação do projeto de urbanização de terrenos, bem como as exigências técnicas e de infra-estrutura a serem realizadas pelos empreendedores. Define ainda a forma de fiscalização e recebimento das obras realizadas pelos empreendedores pela Prefeitura, e como deverão ser executados os serviços. Além disso, estabelece pioneiramente a necessidade dos empreendedores cederem uma caução ao poder público como garantia da realização das obras sob sua responsabilidade. O conteúdo deste capítulo condensa e moderniza todo o processo de elaboração, aprovação e implantação de 
novos loteamentos na cidade, que vinha se constituindo desde os anos 1950 e seria um dos principais instrumentos do poder público para controlar e direcionar a expansão da cidade.

A Reserva de Áreas Públicas para Fins Paisagísticos e da Preservação da Paisagem Natural é objeto de detalhamento pelo capítulo XI. O objetivo é assegurar equilíbrio ecológico e propiciar áreas adequadas à recreação e ao lazer da população, através da reserva de áreas públicas para fins paisagísticos e do seu planejamento adequado, da preservação da paisagem natural e da valorização de acidentes geográficos com importância paisagística. Foram previstas a reserva de 20 áreas públicas para fins paisagísticos, localizadas em terrenos onde se inserem voçorocas. Estas áreas deveriam ser decretadas de utilidade pública dentro de um prazo de 240 dias a contar da vigência da lei do Plano, devendo ser destinadas à implantação de centros de tempo livre, com equipamentos culturais e recreativos. As áreas previstas, após sua implantação, perfazeriam um total de 113 hectares.

Estudos recentes mostram que,

"no que se refere à questão das voçorocas, sua incorporação pelo
controle urbanístico estabelecido pelo Plano Diretor revela uma ação
precursora, em um momento em que a questão ecológica e ambiental
estava sendo formulada a partir das grandes catástrofes em nível global,
a partir dos movimentos ambientalistas" (CHIQUITO, 2006:121).

Além do pioneirismo relativo à questão das erosões urbanas, o capítulo previa a fixação de um percentual de oito por cento das áreas a urbanizar para novas áreas públicas para fins paisagísticos, e mais cinco por cento para usos institucionais. São definidas também especificações mínimas para dimensionar novas praças e áreas públicas, devendo ser dada atenção especial ao planejamento de um lago artificial represando o córrego dos Bagres. Aborda ainda a preservação permanente dos terrenos marginais dos córregos, medida importante para evitar enchentes e a destruição das matas ciliares.

O capítulo XII trata do Planejamento ou Remanejamento de Quadras, estabelecendo regras para a renovação urbana, para projetos de conjuntos residenciais edificações pluri-habitacionais. No capítulo XIII, são tratadas as questões relativas às edificações nos lotes, tais como densidades demográficas, índice de aproveitamento dos lotes e taxa de ocupação. Definem-se recuos obrigatórios e limitações ao processo de verticalização, em especial quanto ao tamanho dos lotes que abrigariam edifícios altos. Também são tratados aspectos dos estacionamentos para veículos nas edificações e das diferenciações zonais para edificar nos lotes. Para a Zona Residencial Central e na Zona Comercial Principal, prevê-se aproveitamento do lote no máximo igual a quatro vezes a área do lote, reduzindo-se esse aproveitamento conforme vai se afastando do centro. Define-se também regras gerais para a futura Zona Industrial, a ser implantada.

A Estética dos Logradouros na Paisagem Urbana é o título do capítulo XIV. O objetivo é assegurar à paisagem urbana autênticas características estéticas e funcionais, desobstruindo calçadas de obstáculos, colocar obras de arte em locais públicos e harmonizar a paisagem. Para isso, são definidas regras para colocação de implementos 
visíveis nos logradouros públicos, tais como bancas, lixeiras, etc. A nomenclatura e o emplacamento das vias recebe um conjunto de regras, assim como a publicidade em locais públicos, como anúncios, letreiros e painéis. A construção e conservação de passeios, o posteamento, a arborização urbana, a instalação de serviços de água e esgoto, tem regras previstas na lei.

O capítulo XVI trata da Renovação Urbanística da cidade de Franca, cujos objetivos principais eram revitalizar e valorizar a paisagem do centro comercial da cidade, adequar usos das edificações, recuperar edificações degradadas e reurbanizar bairros ou zonas, estimular a melhoria das edificações de baixo custo. Os instrumentos para efetuar esta renovação seriam promover o remanejamento de quadras ou lotes, promover a urbanização de terrenos não aproveitados, a fim de atender o interesse social da comunidade (grifo nosso), promover o entendimento entre proprietários de lotes para remanejamento, mediante cooperação do Poder Público, a desapropriação e outros instrumentos, inclusive facilidades fiscais. Para isso, propõe-se a criação do Anel Giratório na Zona Comercial Principal, delimitado pelas ruas Campos Salles, General Carneiro, Ouvidor Freire e Comandante Salgado, com acessos bloqueados e controlados. Trata-se aqui, também, de outra proposta precursora, guardadas as proporções e diferenças, já que estabelece a idéia do atendimento do interesse social da comunidade, promovendo a urbanização de terrenos não aproveitados, proposta que retornaria no bojo do movimento pela Reforma Urbana nos anos 1980, incorporado pela Constituição Federal de 1988 e regulamentado pelo Estatuto da Cidade apenas em 2001.

O capítulo XVII trata da implantação do Plano Diretor, através de uma programação quadrienal, desdobrada anualmente. De quatro em quatro anos, deveria ser feita revisão sistemática do Plano Diretor, considerando-se os aspectos positivos e negativos na execução dos serviços e obras previstas para a implantação do referido Plano. Fixa ainda a competência do prefeito e da Assessoria de Planejamento da Prefeitura no processo de implantação do Plano Diretor.

Institui ainda o Conselho Consultivo do Plano Diretor como órgão de assessoramento do prefeito, praticamente com a mesma composição e atribuições dos Conselhos existentes nas leis municipais elaboradas nos anos 1960 (leis 1204/1963 e 1559/67), seguindo os moldes das Comissões do Plano preconizadas por Anhaia Melo desde os anos 1930 e que, no caso de Franca, nunca foram implantados. O Conselho seria formado pelo chefe da Assessoria de Planejamento, o secretário de Serviços Urbanos, o secretário de Obras Públicas, o procurador jurídico da Prefeitura, um representante da Superintendência de Águas e Esgotos, um representante do Conselho Municipal de Ensino Superior, que seja professor universitário, um engenheiro civil e um arquiteto, de livre escolha do prefeito, um representante do Rotary Clube, um representante do Lions Club, um representante da Associação do Comércio e da Indústria de Franca e dois representantes da Câmara Municipal. Note-se que no Conselho Consultivo do Plano Diretor, há somente representantes da Prefeitura, das elites locais, representadas pelos representantes dos clubes de serviço Lions e Rotary, e de técnicos especializados, nenhum representante dos trabalhadores, de moradores de bairros, de usuários de serviços públicos ou de movimento sociais. É bem verdade que, à época, a organização da sociedade civil em entidades participativas era quase 
inexistente, e os sindicatos de trabalhadores atuavam dentro de limites bastante específicos, exclusivamente de defesa de direitos econômicos de suas categorias profissionais, num ambiente de repressão política. Na prática, no entanto, este Conselho jamais foi constituído, não existiu. Toda a implementação do Plano ficou, de fato, a cargo da Assessoria de Planejamento.

O capítulo XVIII define as responsabilidades da Prefeitura na fiscalização das obras e serviços relativos à implantação do Plano Diretor, detalhando normas para vistorias. O capítulo XIX estabelece as infrações e penalidades, inclusive multas pecuniárias por atividades ou obras que descumprissem o Plano. O último capítulo, o XX, estabelece as Disposições Finais e Transitórias, que tratam de aspectos administrativos específicos, tais como validade de licenças já expedidas antes da promulgação da lei e aspectos correlatos.

A Lei do Plano Diretor Físico consolidou e modernizou um conjunto de diretrizes e regras sobre o uso, ocupação e parcelamento do solo da cidade e sobre o planejamento territorial urbano de Franca que vinham sendo perseguidas desde os anos 1950. Sua aplicação, mesmo que parcial, permitiria ao poder público local realizar investimentos e exigir do setor privado que assumisse responsabilidades que não existiam antes, sendo responsável por considerável impacto na produção do ambiente construído local, principalmente no fornecimento de infra-estrutura, áreas públicas e sistema viário dos novos loteamentos. 


\section{4}

\section{O PLANO DIRETOR DE FRANCA: DO PAPEL À PRÁTICA}

\section{CONTEXTO E EFETIVIDADE DO PLANO DIRETOR DE FRANCA}

A literatura disponível sobre o planejamento urbano desenvolvido durante os anos do período autoritário, principalmente aquele elaborado sob a égide do Serviço Federal de Habitação e Urbanismo - SERFHAU, com raras exceções, geralmente tem apresentado análises genéricas que descrevem os Planos daquele período como de baixa efetividade, sendo considerados como "planos de gaveta", "papel pintado" e outras referências ainda menos elogiosas quanto à sua utilidade e eficácia. A julgar por aí, pode-se considerar que a produção e os planos daquele período foram totalmente inócuos.

Este julgamento, por demais severo e simplista, no entanto, desconsidera totalmente que a institucionalização de um processo de planejamento e a implantação de um Plano Diretor numa prefeitura de uma cidade do interior pode ser considerada um desafio por si só, diante das enormes dificuldades e precariedades vivenciadas pelo poder público no Brasil, especialmente o municipal, que é o ente federativo que até hoje fica com a menor parcela de recursos do setor. Não compactuo da visão que todos os planos funcionaram, seria cair no extremo oposto, mas sim que a leitura dos planos diretores do período do SERFHAU deve ser relativizada, suas realizações não podem ser simplesmente obscurecidas pelos tempos da ditadura.

Como verificamos nos capítulos anteriores, o processo de elaboração do Plano Diretor e de planejamento recomendado pelo SERFHAU se iniciou na Prefeitura de Franca após a contratação de uma empresa de consultoria externa, o GPI, que produziu 
e deu as condições básicas para estabelecer uma nova legislação municipal, tendo como horizonte uma reestruturação administrativa interna e a elaboração de um conjunto de propostas que visava modernizar não só a administração pública, mas também o espaço físico da cidade.

Ou seja, a ação do SERFHAU deve ser observada também a partir da motivação e dos financiamentos que propiciaram a elaboração não somente de Planos Diretores, chamados integrados, de eventual conteúdo abrangente e generalista, mas também da possibilidade de dar corpo a uma reestruturação e modernização das prefeituras.

É bem verdade que, no caso específico de Franca, este interesse pela modernização administrativa era almejado desde o início do governo de Flávio Rocha, nos primeiros anos da década de sessenta. Este movimento vinha no bojo de um processo defendido pelos municipalistas desde a década de 1940, de modernização do serviço público, e intensificado na década seguinte (FELDMAN, 2005a).

A lei municipal n. 1188, de 9 de dezembro de 1963 é uma das primeiras leis que tratam de um planejamento para as ações da Prefeitura, absorvendo as idéias municipalistas difundidas naquele período. Sabe-se também que a partir de 1964, a lei federal n. 4.320 passou a exigir de todos os entes da federação a utilização do orçamentoprograma para a elaboração orçamentária, como forma de permitir um maior controle de receitas e despesas do setor público, embora as altas taxas de inflação do período tenham reduzido sua eficácia.

Porém, podemos afirmar que foi somente a partir da lei municipal de número 1.559/1967, que instituiu o Sistema de Planejamento de Desenvolvimento Integrado o Município, que se iniciou de fato um amplo processo de modernização e integração da administração local, da legislação municipal ${ }^{1}$, da criação de instrumentos técnicos de controle do espaço urbano, como um cadastro técnico imobiliário de maior qualidade, de normas e procedimentos de serviços, de mecanismos burocráticos de controle, tanto fiscais quanto de procedimentos internos. Ressalte-se ainda a realização de concurso público para o acesso às carreiras do setor público municipal em 1969, após a aprovação da lei n. 1699, de 12 de dezembro de 1968, que criou cargos e modificou o enquadramento de pessoa ativo e inativo do funcionalismo público municipal, ampliando e profissionalizando quadros técnicos com maior competência ${ }^{2}$.

Evidentemente, há muitos aspectos daquele planejamento que não se concretizaram. Um dos focos centrais do Plano, que era limitar a cidade e combater sua expansão horizontal e os vazios urbanos, não teve respaldo político para ser implementada. Porém, mesmo esta iniciativa, de combater a expansão horizontal, foi tentada pela administração, ou seja, o Plano foi um instrumento utilizado, mesmo que tenha fracassado neste aspecto.

\footnotetext{
${ }^{1}$ Foram elaboradas pelo GPI e aprovadas pela Câmara Municipal, além do Plano Diretor, as leis que instituíram os novos Código de Edificações (1647/68), Código Tributário (1672/68) e o Código de Posturas (2047/72).

${ }^{2}$ Depoimentos nas entrevistas com José Suavinho, Marco Résio e Weber David apontam as mudanças operacionais internas como definidas pelo processo de planejamento implantado a partir do Plano Diretor, assim como a reestruturação interna da Prefeitura.
} 
Em 1969, uma das primeiras medidas do governo de Lancha Filho é estabelecer, através da lei 1.749, de 30 de junho, uma delimitação do perímetro urbano da cidade de Franca. Este perímetro tinha forma poligonal, definindo com maior clareza a área urbana. Logo em seguida, em 30 de abril de 1970, através da lei 1.859, estabeleceu-se uma proibição para aprovar novos planos de loteamentos e arruamentos no Município de Franca. Seu artigo primeiro dizia que

nenhum projeto de loteamento ou arruamento de áreas urbanas será aprovado pela Prefeitura Municipal, até que entre em vigor o Plano Diretor de Desenvolvimento Integrado do Município. Excetuam-se da proibição de que trata esta lei, os loteamentos que apresentem, previamente, no mínimo três dos seguintes melhoramentos: energia elétrica, água, esgoto, pavimentação, guias e sarjetas, galeria de águas pluviais.

Na prática, embora o objetivo fosse bloquear a expansão da cidade sem a respectiva infra-estrutura, a exigência de instalação pelos empreendedores de apenas alguns elementos de infra-estrutura tornava inócua a lei, pois a colocação de guias e sarjetas, água e energia elétrica eram procedimentos relativamente simples, sem grandes custos a onerar os empreendedores. O fato é que a cidade vivia um explosivo crescimento demográfico no período, próximos de 5\% ao ano. (PREFEITURA MUNICIPAL DE FRANCA [1971?a]:47)

A solução política encontrada pela administração municipal foi liberar os loteamentos, sem grandes preocupações com a sua capacidade de fornecer a infraestrutura urbana necessária, à revelia das recomendações do Plano Diretor. Os controles foram frouxos também quanto ao zoneamento de uso do solo: o longo tempo decorrido entre a proposta e a real implantação do Distrito Industrial impossibilitou politicamente ao governo municipal tentativas mais abrangentes de implementar um zoneamento mais rígido, pois as empresas de calçados começavam em fundos de quintais e se expandiam sobre as zonas residenciais próximas. (FERREIRA, 1989)

Estas são características da cidade até os dias de hoje, de um uso misto envolvendo habitações e pequenas indústrias calçadistas. Apesar disso, as tendências de uso apresentadas na lei se consolidaram, principalmente as intituladas Zona Comercial Principal, Zona Comercial Noroeste, Zona Comercial Oeste I e Oeste II, Zona Comercial Noroeste. A Zona Especial de Esportes recebeu o estádio municipal. A Zona Especial Educacional I recebeu os prédios das duas faculdades municipais, de Direito e de Ciências Econômicas, onde se encontram até hoje. É importante ressaltar que tais investimentos, definidos pela própria Prefeitura, foram incorporados ao Plano até mesmo no zoneamento de uso do solo. Ou seja, a crítica que geralmente se faz a diagnósticos exaustivos e feitos por especialistas que desconhecem a realidade local não se sustenta totalmente no caso de Franca.

A Zona Especial de Feiras e Exposições, onde está situado o parque Fernando Costa, destinado a exposições agropecuárias, embora tenha mantido este uso, não recebeu os investimentos destinados à implantação do parque de exposições calçadistas (Francal), que ficou localizado na zona sul, fora da área urbana prevista na lei, assim 
como as instalações do complexo Poli esportivo, ambos construídos entre 1970 e 1974. Mas isto pode ser explicado pelo fato que o Parque Fernando Costa pertence ao Estado e não ao município, que preferiu investir em área própria ${ }^{3}$.

No entanto, como verificaremos adiante, além da reestruturação interna da Prefeitura, um conjunto bastante significativo das intervenções físicas propostas do Plano Diretor, descritas na Política de Desenvolvimento Físico e tornadas obrigatórias pela Lei do Plano Diretor Físico, foram realizadas ao longo de quase dois decênios, por diversos governos.

Com isso, queremos afirmar que, no caso de Franca, a crítica geral ao planejamento efetuado durante o período dos governos militares, não pode ser automaticamente aplicada, pois há evidências bastante fortes de sua aplicação e efetividade, no sentido de que foi possível almejar sua transformação em compromissos do poder público local, ainda que isto não fosse claramente evidenciado nos discursos dos seus governantes.

Com base na leitura da Política de Desenvolvimento Físico e na Lei do Plano Diretor Físico, dentre as dezenas de propostas, procuramos identificar, verificar e selecionar as obras e atividades desenvolvidas a partir dos trabalhos do GPI, principalmente aquelas de maior impacto e que interferiram na configuração do espaço físico da cidade, que consideramos como principais, e que tiveram como ponto de partida as propostas do Plano, cotejando-as com a realidade atual, a saber:

- Distrito Industrial

- Avenidas preferenciais e seus cruzamentos

- Pedestrianização do centro

- Parque do Vale dos Bagres

- Transformação de voçorocas em áreas de lazer

Além das propostas físicas, incluímos também a questão da Modernização Administrativa pelo fato da Prefeitura institucionalizar uma estrutura de planejamento que, embora perseguida desde a década de 1950, era inexistente até então, e que vai se responsabilizar pelo desenvolvimento das propostas físicas do Plano Diretor.

Consideramos importante também analisar o Plano de Ação proposto pelo GPI, que contempla as diretrizes gerais da Política de Desenvolvimento Integrado do Município, que envolviam a promoção e orientação do desenvolvimento econômico, social e físico, a racionalização e dinamização da administração municipal e a expansão das redes de equipamentos urbanos e de serviços públicos de forma a atender a necessidade de toda a população local.

Ora, este Plano de Ação colocava como peça fundamental do planejamento o Plano Plurianual, contendo um orçamento dos investimentos necessários, abrangendo o período de 1970-1973. Pode-se verificar que o Orçamento Plurianual proposto para aquele período continha recursos para a construção das seguintes obras:

${ }^{3}$ Somente no início dos anos 90 o Estado cedeu o Parque Fernando Costa para a Prefeitura administrar, ainda assim em comodato. 
- Paço Municipal (que se efetivou em 1970);

- para a elaboração do projeto do Distrito Industrial (a área foi adquirida e se efetivou em 1984);

- para a construção do Pavilhão de exposições calçadistas, a Francal (que se efetivou em 1972);

- para implantação do corpo de bombeiros (que se efetivou em 1970);

- para a construção da nova rodoviária (que se efetivou somente em 1979);

- construção do estádio municipal (que se efetivou em 1969);

- construção do colégio técnico industrial (que se efetivou em 1971);

- canalização de córrego e urbanização do vale dos Bagres (que se efetivaram, ao longo de 20 anos);

- construção das avenidas marginais (que se efetivaram ao longo de quase 20 anos) (PREFEITURA MUNICIPAL DE FRANCA, [197-?]b)

Ou seja, as principais propostas presentes no Plano e as obras previstas para aquele período se concretizaram naqueles anos ou nos subsequentes.

Com isso, queremos reafirmar que o Plano Diretor de Franca, por suas propostas e efetivas realizações, não corrobora a idéia que o planejamento do período do SERFHAU foi apenas "papel pintado" arquivado nas prateleiras da prefeitura. É preciso considerar também o contexto em que se dá este planejamento, de limitação das liberdades democráticas e de centralização de recursos em nível federal, dentre outros aspectos, tolhendo a capacidade de intervenção do poder local.

Apesar de todas as limitações do período, o Plano Diretor de Franca estava sintonizado com algumas das principais idéias e propostas dos urbanistas e planejadores daquele momento:

- a devolução do centro das cidades aos pedestres e a restrição para circulação dos veículos motorizados;

- o incentivo à industrialização como motor do desenvolvimento, ao lado de um zoneamento de uso que destinasse área específica às indústrias (distritos ou parques industriais);

- a ampliação das áreas verdes urbana e de uso coletivo, através de parques urbanos;

- a ampliação do sistema viário para integrar áreas novas às cidades que cresciam velozmente;

- a modernização da administração pública para permitir o atendimento das demandas por serviços públicos.

Desta maneira, as propostas do Plano de Franca podem ser comparadas com aquelas elaboradas em outras cidades no mesmo período, verificando-se inclusive certa identidade entre elas e, ao mesmo tempo, a efetividade de alguns aspectos de outros planos realizados no período do SERFHAU, que demandam novos estudos e pesquisas. 
A paradigmática Curitiba, cujo Plano foi transformado em lei em 1966, tinha como propostas a criação de uma Cidade Industrial para promover a industrialização, a mudança de enfoque na questão do transporte coletivo e do sistema viário estrutural (problema ainda incipiente em Franca, por sua população à época), o zoneamento, os grandes parques urbanos, o tratamento diferenciado à região central, através dos calçadões (OLIVEIRA, 2003).

Campinas é uma destas cidades cujo Plano Preliminar de Desenvolvimento Integrado foi elaborado no mesmo período que o de Franca, transformado em lei em 1971, na gestão do prefeito Orestes Quércia. A construção de grandes avenidas e modernização do seu sistema viário durante o governo de Lauro Péricles Gonçalvez, (1973-1977) previstas no Plano direcionaram a expansão da cidade para áreas então desocupadas, bem como a implantação do Distrito Industrial de Campinas - DIC (PREFEITURA DE CAMPINAS, 1995).

São José do Rio Preto é outra delas, onde a criação de distritos industriais prevista pelo Plano foi determinante para mudança de seu perfil, de agrícola para industrial (BUENO, 1979). O caso da cidade de Votuporanga, outro município localizado no norte do estado de São Paulo, também possui similaridades com Franca. Elaborado pelo GPI, os trabalhos do Plano foram iniciados em 1967 e concluídos em 1970. Segundo o engenheiro Jesus Silva Melo, o Plano Diretor de Votuporanga propôs a criação de uma secretaria de Planejamento na administração municipal, que propiciou a implementação de diversos aspectos previstos pelo Plano, como o cadastro técnico municipal, o incremento do processo de industrialização do ramo moveleiro (distrito industrial) e o zoneamento de uso do solo ${ }^{4}$. No caso de Franca, o orgão de planejamento se manteve e, embora tenha se transformado ao longo do tempo, consolidou-se definitivamente na estrutura do executivo municipal.

Contudo, estes elementos são pistas a serem seguidas, serão necessários estudos e pesquisas mais aprofundados para confirmar as similaridades e efetividades destes outros municípios com Franca e com as diretrizes do SERFHAU, que não são objetivos deste trabalho.

\section{A INDUSTRIALIZAÇÃO PAULISTA E AS IDÉIAS SOBRE DISTRITOS INDUSTRIAIS}

O Distrito Industrial foi objeto específico de detalhamento num dos volumes do Plano Diretor de Franca, revelando a grande importância ocupada pelo setor calçadista nas propostas.

O termo "distrito industrial" tem sido usualmente utilizado para designar qualquer forma de aglomeração industrial, desde um arruamento, um loteamento até a concentração espontânea de indústrias num determinado local ou região. Geralmente, as concepções de distrito industrial se fundamentam em duas considerações principais: necessidade de atender às exigências da legislação trabalhista e a acirrada disputa nos mercados interno e externo que exigem maior complexidade administrativa e comercial.

${ }^{4}$ Informações obtidas em depoimento ao autor em 22/02/2007. 
Segundo GARCIA (1996), podem-se definir os distritos industriais como aglomerações de empresas de pequeno e médio porte de um mesmo setor ou segmento industrial localizadas numa área geográfica limitada, configurando-se ainda por características específicas como a existência de relações interempresariais, que intensificam a especialização em algumas etapas do processo produtivo e possibilitam ações coletivas; redução da burocracia e verticalidade das empresas e capacidade de fornecer resposta rápida e flexível às mudanças da demanda; internalização da capacidade tecnológica, que permite um processo constante de inovação tecnológica nos produtos.

Citando Zeitler, GARCIA (1996) afirma ainda que os distritos industriais "representam uma das formas de manifestação do conceito de especialização flexível", decorrentes em parte do processo de descentralização das grandes empresas, articulando-se com pequenas e médias empresas colaboradoras, fenômeno que se evidenciou no sistema produtivo europeu a partir dos anos 1960. Tal sistema demonstrou a viabilidade dos distritos industriais como alternativa de organização da produção, envolvendo a atuação governamental local, que propiciou acesso a financiamentos, a capacitação tecnológica e a infra-estrutura urbana necessária aos empreendimentos.

Um dos primeiros projetos de uma cidade industrial é atribuído ao francês Tony Garnier, desenvolvido entre 1901 e 1904, que incorporava a idéia de uma divisão entre a zona industrial e a residencial separada por um cinturão verde. Parece que o primeiro distrito industrial foi implantado em Manchester, Inglaterra, em 1896, por um grupo de investidores privados. Em 1905, uma empresa privada fundou, nas proximidades de Chicago, os Central Manufactoring Districts, e em 1904, na Itália, a Prefeitura de Nápoles criava sua zona industrial, administrada pelo poder público. Na Inglaterra o programa de implantação de distritos industriais foi iniciado a partir de 1935, motivado pelos efeitos decorrentes do "crack" da bolsa norte-americana e da depressão econômica do período. (FERRARI, 1977)

A União Soviética, no seu esforço para industrializar o país, criou a partir de 1926 e dos Planos Econômicos Qüinqüenais, mais de mil novas cidades industriais. Outros países em desenvolvimento, como a Índia, desenvolveram amplos programas de construção de distritos industriais, a partir de 1952, com o objetivo de fomentar a instalação de pequenas e médias empresas, com uso intensivo de mão de obra, exemplo seguido pelo México e por Porto Rico. A experiência brasileira com cidades industriais inicia-se com a construção da pioneira cidade industrial de Contagem, em Minas Gerais, em 1941. A política desenvolvimentista de Getúlio Vargas e Juscelino Kubistcheck, nos anos 1950, incentivam a industrialização e o avanço dos investimentos em siderurgia em Minas Gerais vão fazer surgir instalações industriais e o planejamento do seu entorno, como em Ipatinga e João Monlevade. No período imediatamente posterior, já durante o regime militar, vai ocorrer o surgimento de distritos industriais em dezenas de cidades brasileiras, como Aratu (Bahia), Caxias (RJ), Porto Alegre (RS), Curitiba e Ponta Grossa (PR), Presidente Prudente (em SP, projetado pela FAU USP), Joinville (SC) Fortaleza (CE) e muitas outras. (FERRARI, 1977)

Os principais elementos a serem destacados da experiência internacional com distritos industriais estão relacionados ao entrelaçamento de relações entre as empresas, 
ao papel dos agentes exportadores e importadores, a identidade sociocultural, a atmosfera industrial local, o papel decisivo determinado pelo apoio das autoridades locais, a presença de instituições complementares e de apoio ao setor industrial, a manutenção de padrões de qualidade e tecnologia, grande capacidade de sobrevivência das empresas, dinamismo e alta competitividade (GARCIA, 1996).

A questão das políticas públicas de fomento à atividade industrial no Brasil, presentes na formulação de incentivos à atividade e na proteção às atividades produtivas, tem sua discussão focada nas tarifas aduaneiras ou nas oscilações da taxa de câmbio, o que obscurece a questão do apoio local à industrialização, presentes na forma de incentivos fiscais de impostos locais ou na cessão subsidiada de terra urbanizada, como na maior parte dos distritos industriais construídos no país.(SUZIGAN, 1986)

As desigualdades regionais do país, no início da década de 1960, eram pensadas como superáveis pelo uso das técnicas de planejamento. Por outro lado, da mesma forma que a divisão internacional do trabalho teria aumentado as disparidades regionais em prejuízo dos paises subdesenvolvidos, alegava-se que no Brasil, internamente, havia uma "injusta divisão territorial do trabalho" em função da crescente concentração industrial em São Paulo e a conformação de uma produção predominantemente primária na periferia nacional. A industrialização, era, portanto, vista como uma necessidade, para desenvolver as regiões mais pobres. (CANO, 1977)

O período que vai de 1956 a 1967 é considerado a primeira fase da industrialização pesada do Brasil, concentrada principalmente em São Paulo. Medidas governamentais foram decisivas para isso, tais como a reforma cambial de 1953, que possibilitava melhor remuneração do exportador, a atração de investimentos estrangeiros ampliada por instrução governamental de 1955 e a criação de novos organismos estatais de fomento, como o Banco Nacional de Desenvolvimento Econômico - BNDE em 1952 e a criação da Petrobrás, em 1954. O protecionismo à indústria nacional foi ampliado ainda mais porque, além dos investimentos estatais na produção direta de insumos básicos, como combustível e aço, além de uma rede básica de infra-estrutura, como em energia e nas várias modalidades de transportes, foram decisivas a utilização dos instrumentos de política econômica apontados anteriormente e o oferecimento de crédito subsidiado a setores considerados prioritários, incluindo-se também a concessão de terrenos industriais e isenções de importação de máquinas e equipamentos pesados. A segunda fase de industrialização pesada, a partir de 1967, vai aprofundar as discussões sobre a interiorização e desconcentração industrial paulista. Durante o governo de Abreu Sodré (1967-1971), criou-se um grupo de trabalho com o objetivo de definir diretrizes para uma política de descentralização industrial, cogitando inclusive a criação de distritos industriais nos núcleos urbanos mais dinâmicos, o que mostra que a proposta do GPI para um distrito industrial em Franca estava sintonizada com o debate sobre os rumos da economia paulista que se realizava naquele momento. O governo seguinte, dirigido por Laudo Natel (1971-1975), adotou uma forte política de interiorização, que previu a construção de estradas, elaboração de diagnósticos sócio-econômicos das regiões do estado, utilização dos escritórios regionais de planejamento como instrumento de ação estatal, assessoria a projetos de relocalização industrial e a criação de uma companhia ambiental para controlar a reinstalação industrial. Esta política de interiorização do 
desenvolvimento subordinou-se, de modo geral, a interesses empresariais, deixando fluir as decisões espontâneas de localização industrial. Na fase mais intensa da industrialização do estado, com a concentração das atividades em um número relativamente reduzido de cidades, as administrações municipais do interior do Estado viram-se estimuladas a implantar áreas e distritos industriais, como forma de atrair indústrias na expectativa de aumentar a receita municipal através da arrecadação do Imposto de Circulação de Mercadorias - o ICM. Os problemas da produção industrial envolvem basicamente duas questões: uma regional e outra local, o que envolve um processo de escolha de áreas onde se possa produzir de forma mais econômica, e de definição do lay-out industrial, com o objetivo de minimizar os custos de produção e otimizar os lucros. Assim, os estudos dos fatores locacionais devem incluir o fator transporte, os aglomerativos e os desaglomerativos, no sentido de buscar uma maior eficiência produtiva, ganhos de escala e competitividade no mercado (NEGRI, 1992).

Outro aspecto que ganha relevância é o ambiental, para efeito de agrupamento e zoneamento industrial em função dos diferentes critérios de análise e licenciamento das atividades, envolvendo os graus de nocividade das atividades industriais, tais como o grau de emissão de ruídos, gases, fumaça, poeira, odor, calor, riscos de incêndio ou explosão, efluentes líquidos, etc. (FERRARI, 1977).

A indústria surge como um dos fatores que mais contribuiu para a instituição do zoneamento, pois a segregação que é compelida pelo zoneamento vem ao encontro dos interesses das próprias indústrias, na medida em que passam a atuar em ambientes muito mais vantajosos, em função de diversos fatores, como a dimensão e custo das áreas para sua instalação, facilidades de circulação e transporte de matéria-prima e produtos acabados, disponibilidade de mão de obra, facilidades relativas ao meio ambiente. (PUPPI, 1980)

A política adotada pelo governo paulista, durante os anos 1970, considerava os distritos industriais como importante instrumento de política regional, pois teria condições de desempenhar diferentes funções, de acordo com as peculiaridades das regiões em que seriam implantados. Além disso, demonstrariam que sua eficácia está intimamente associada à presença de fatores locacionais demandados pelo próprio empresariado e que a concentração planejada de indústrias consiste, em linhas gerais, na utilização de instrumentos a nível governamental capazes de induzir e viabilizar a expansão do processo de industrialização de forma ordenada, incorporando elementos no sentido de aumentar ou pelo menos preservar o nível de eficiência produzida. Em linhas gerais, o governo paulista afirmava que os distritos e áreas industriais se constituíam em instrumentos para uma ação descentralizadora e disciplinadora do espaço territorial paulista, dada a sua capacidade de ordenar o solo urbano e de oferecer vantagens proporcionadas pela economia de escala e de aglomeração, desde que sua implantação se processasse através de um planejamento industrial integrado. (SÃO PAULO, 1980)

Verifica-se, portanto, uma longa relação entre a ação do Poder Público no Brasil e o fomento à atividade industrial e, dentre elas, a constituição de distritos industriais como elementos importantes na política de industrialização, em experiências disseminadas por todo o país, não se constituindo Franca numa exceção neste aspecto. 
Ao mesmo tempo, pode-se afirmar que a iniciativa privada, com raras exceções nos anos 1960 e 1970, não realizou investimentos de infra-estrutura como loteamentos ou áreas industriais, tarefa que ficou quase exclusivamente vinculada às ações do Poder Público, principalmente como incentivo à industrialização local ou regional.

\section{A GÊNESE DO DISTRITO INDUSTRIAL DE FRANCA}

O documento técnico elaborado pelo GPI como um dos volumes do Plano de Desenvolvimento Integrado de Franca, recebeu o título "Viabilidade do Distrito Industrial" que, nas suas 26 páginas e num mapa de proposta de localização procurava complementar o Diagnóstico do Plano, "apresentando preliminares sobre a viabilidade e a conveniência de um Distrito Industrial em Franca", entendendo o Distrito como um elemento que propiciaria desenvolvimento econômico e urbano, pois possibilitaria integrar diversos elementos de uma política industrial local, além da localização e infraestrutura adequada, envolvendo também subsídios técnicos e fiscais aos novos empreendimentos a serem fixados no mesmo. A introdução do documento deixa clara a idéia que a simples venda de terrenos a baixo preço não se constituiriam em diferencial para atrair indústrias de outras regiões.

Na concepção do Plano, o Distrito

poderia desempenhar duas funções básicas: de um lado, racionalizar e regulamentar o uso do espaço urbano para fins industriais, capacitando determinadas áreas para receber este tipo de atividade econômica, (PREFEITURA MUNICIPAL DE FRANCA, [1971?c]:4)

numa concepção de regular o zoneamento urbano, e de outro lado, "promover novos investimentos industriais", através de redução de custos de instalação e operação.

O fato de a indústria local estar esparramada por toda a malha urbana, misturada a usos residenciais, até mesmo na região central, não se constituía, segundo o estudo, em problema de maior gravidade, "exceto, talvez, a poluição ambiental gerada pelos curtumes", porém tais inconvenientes poderiam se agravar na medida em que a industrialização se acelerasse, transformando-se num obstáculo importante ao "desenvolvimento integrado e harmônico das funções urbanas".

Justificava-se, portanto, do ponto de vista territorial, a implantação do Distrito Industrial para a "racionalização do uso do espaço urbano", embora os altos custos necessários para sua viabilização em infra-estrutura não se apresentassem como prioridade naquele momento, "como a melhoria de infra-estrutura na área urbana, a extensão do sistema viário interno e as obras relacionadas ao ensino e à assistência médico-hospitalar à população".

Já em relação ao desenvolvimento econômico, portanto à atração de novos empreendimentos industriais, o Diagnóstico deixou evidente que para gerar emprego 
e renda para os trabalhadores que migravam do campo para a cidade seria mais viável no desenvolvimento da indústria de transformação, o que ensejava o desenvolvimento industrial como uma meta importante para o governo municipal, indo ao encontro dos interesses do setor calçadista.

Para que este desenvolvimento industrial ocorresse, o Plano discute duas alternativas: de um lado, "a expansão da produção industrial baseada na estrutura atualmente existente" e, de outro, "a expansão da produção industrial mediante a diversificação da estrutura atual".

A análise efetuada pelo GPI indica claramente o rumo a tomar: utilizar o Distrito Industrial como estímulo à expansão da indústria existente no município, um próspero complexo coureiro-calçadista, uma vez que as informações disponíveis naquele momento indicavam perspectivas otimistas para o ramo, que começava a ganhar escala e o mercado internacional, em especial o norteamericano. $\mathrm{O}$ peso da indústria calçadista para a cidade havia se tornado fundamental para sua economia.

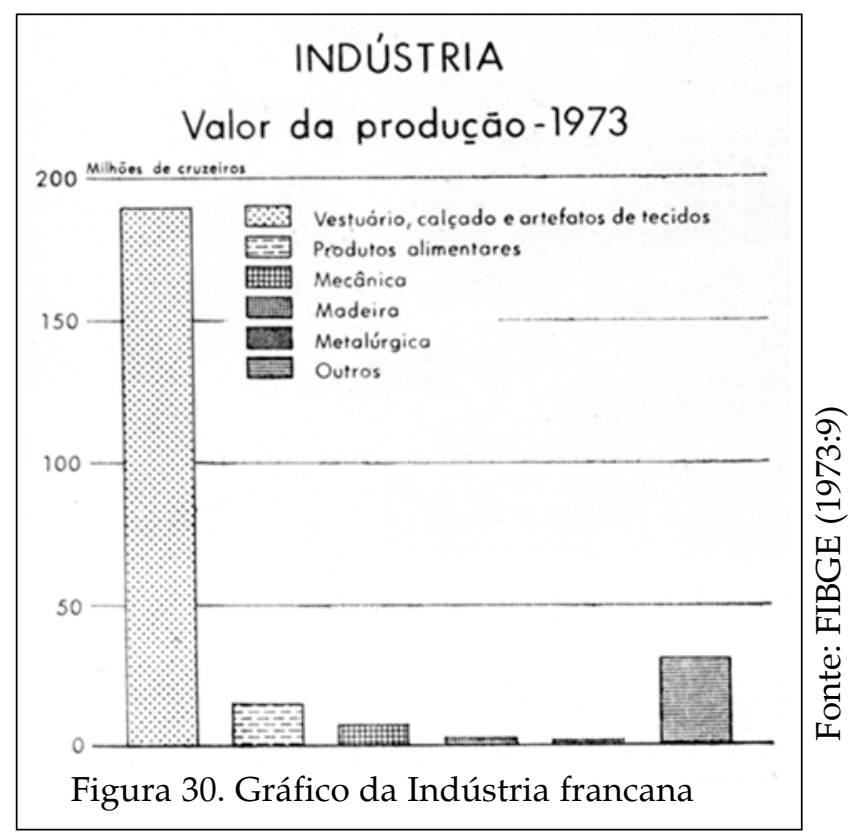

O estudo aponta ainda que,

para se atingir o objetivo de exportação ao mercado norte-americano é necessário realizar gestões, seja através de órgãos oficiais, seja diretamente junto a importadores daquele país. Ao mesmo tempo, duas providências devem ser tomadas: a união das principais indústrias da cidade e a modernização dos curtumes locais, de modo a melhorar a qualidade do couro. (PREFEITURA MUNICIPAL DE FRANCA, [1971?c]:9) 
Em relação à atração de outras indústrias, o estudo aponta as limitações do município, quer pela sua localização em relação a Ribeirão Preto, o pólo regional mais importante, quer pela rede de transportes e estrutura de comércio e serviços altamente desenvolvida e que gera economia externa superior ao que Franca poderia oferecer, configurando uma enorme vantagem para Ribeirão Preto na atração de investimentos.

Com isso, o estudo conclui que

qualquer que seja o desenvolvimento futuro da indústria de Franca, tudo indica que a orientação dos novos investimentos não irá mudar, seja pela inexpressividade do volume da produção agrícola do Município e das áreas próximas, seja pela existência de uma estrutura industrial formada dentro da mesma orientação. (PREFEITURA MUNICIPAL DE FRANCA, [1971?c]:12)

A partir destes elementos, o Plano apresentou uma pré-estimativa de ocupação de áreas industrial, com a perspectiva de 10 anos, até 1980, baseada nas indústrias de calçados e de couro, que eram a maioria e que ocupavam a maior área urbana, estimando uma necessidade de área até 1980 de 70 hectares. A metodologia para estudar as áreas alternativas utilizou, em princípio, fotos aéreas.

O trabalho procura analisar a realidade local, envolvendo a infra-estrutura já existente e a facilidade de implantação em glebas virgens, assim como a proximidade e afastamento da área urbanizada e os riscos de poluição ambiental.

O estudo apontou as áreas mais favoráveis como sendo aquelas situadas no setor sudoeste da cidade, próximas à rodovia Franca-Araxá, Franca-Barretos e a Estrada de Ferro Mogiana, sob os seguintes argumentos: afastamento das aglomerações residenciais, embora distante apenas $3 \mathrm{~km}$ do centro da cidade; proximidade das rodovias; proximidade da estrada de ferro; proximidade de linhas de energia elétrica de alta tensão; mananciais hídricos próximos e de fácil captação; facilidade de ocupação, pois ocupadas atualmente por pastagens; situação favorável quanto aos ventos dominantes; suave declividade, facilitando redes de água, esgotamento sanitário e drenagem, além de não exigir grandes terraplenagens. Seria possível também construir uma estação de esgotos industriais, com capacidade para tratar também os esgotos domésticos da cidade. A proposta de ocupação seria realizada em três etapas. 


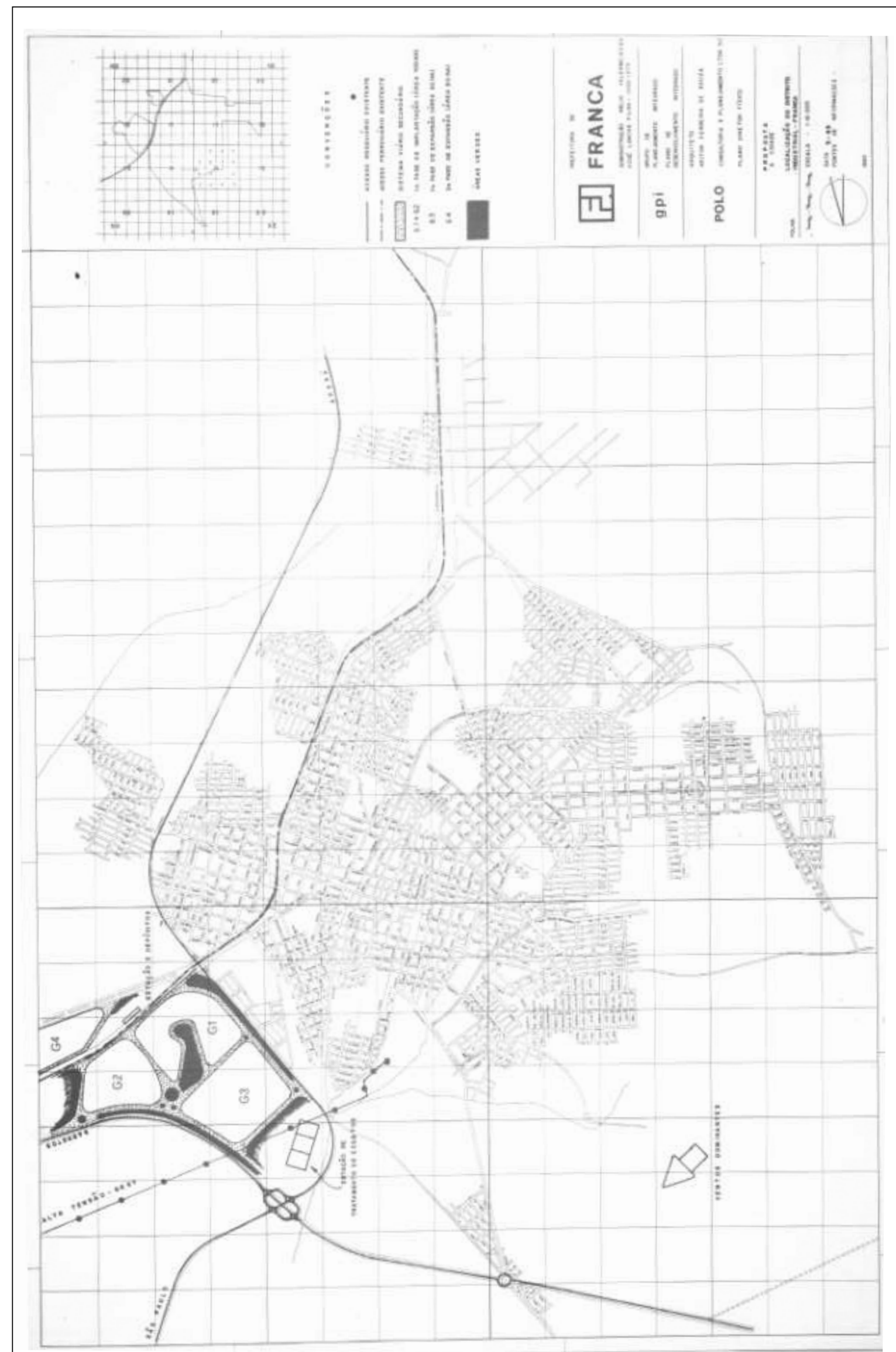

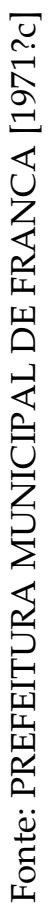

Mapa 5. Localização do Distrito Industrial 
Feitas todas as considerações de ordem física, o Plano indica a necessidade de se elaborar um "Plano do Distrito Industrial", que deveria conter as medidas de caráter legal necessárias para a desapropriação das áreas; a elaboração dos projetos institucionais, como a lei que criaria o Distrito, suas normas e regulamentações; a estrutura de ação, operacional; os estudos econômicos; o projeto de urbanização da área do Distrito Industrial; os projetos técnicos de infra-estrutura urbanística; os projetos financeiros; e, finalmente, o plano promocional, com os perfis do município e os incentivos à industrialização local.

A proposta, desta maneira, encaminha uma idéia básica inovadora, a da criação de uma política industrial local, com base na inserção de Franca na região e nas dificuldades que a indústria calçadista teria para se expandir. Ao mesmo tempo, especifica a necessidade de um zoneamento de uso do solo mais rígido na cidade existente, como instrumento de racionalização do espaço urbano e de redução das incomodidades ocasionadas pela indústria.

Nos anos seguintes, assuntos ligados à indústria calçadista vão ser constantes na imprensa, especialmente no jornal "Comércio da Franca", com críticas recorrentes às medidas do governo federal e à difícil situação da indústria local frente às restrições ao crédito, porém em nenhum momento localizamos qualquer reivindicação direta do empresariado quanto à necessidade de um Distrito Industrial para a cidade neste período, mas isso não quer dizer que a proposta não tenha tido acolhida ou vista como desnecessária, o que se dará mais adiante.

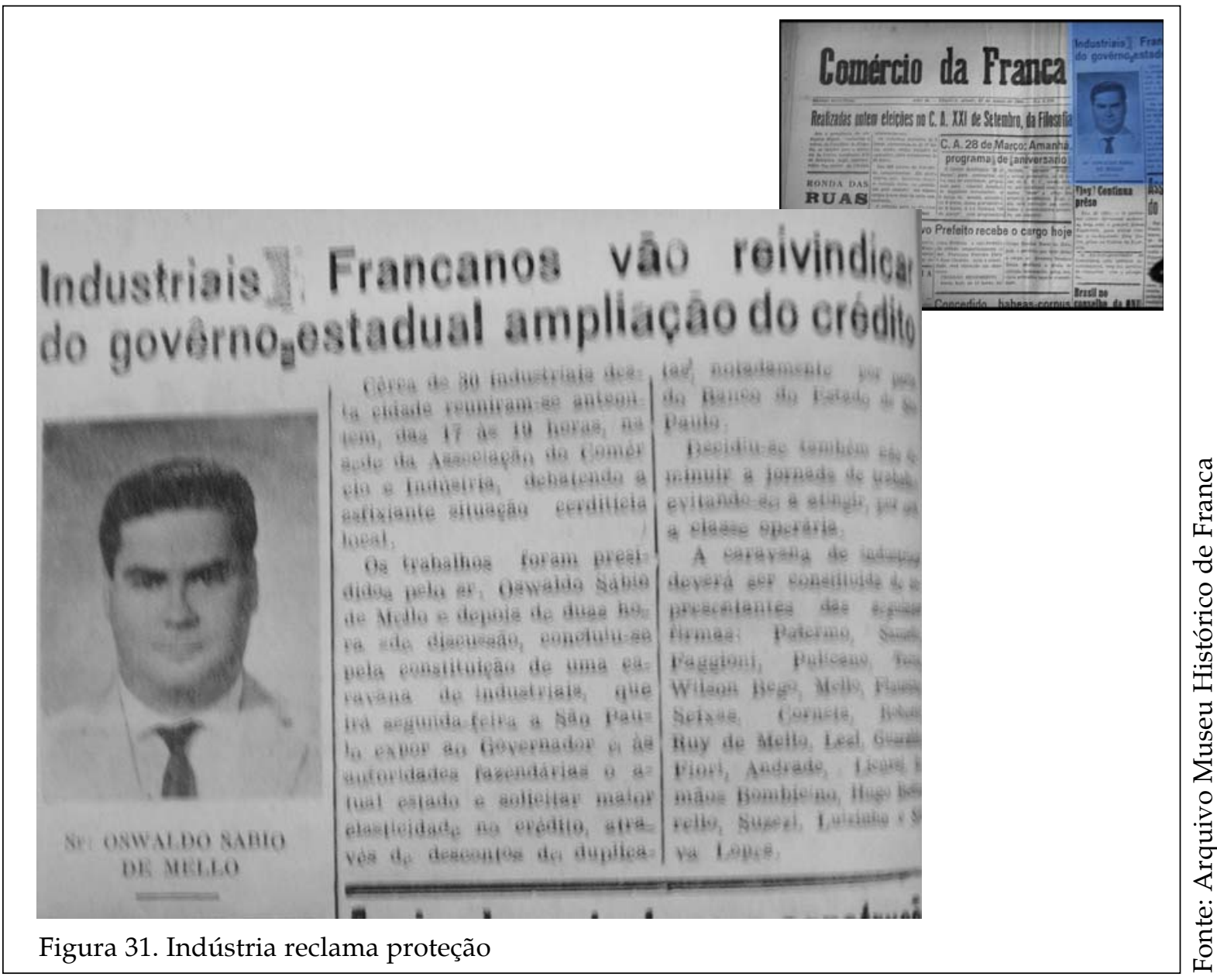


Em contrapartida às preocupações de ordem econômica do setor coureirocalçadista, começam a surgir reclamações da população quanto à "fedentina na Vila Industrial" ${ }^{\prime}$, onde se situavam os curtumes, às margens do córrego do Cubatão, localizados na região central da cidade desde o final do século XIX, então já totalmente envolvidos pela urbanização e ocupação densa de seu entorno e da colina da Santa Cruz.

É bom lembrar que a construção da avenida marginal ao córrego e sua canalização também foi um fator de atração para novos empreendimentos na região, criando uma nova centralidade incompatível com a continuidade dos curtumes no lugar. Serão exatamente os curtumes, inicialmente, as indústrias a reivindicar a necessidade do Distrito, já na década de 1970, depois do Plano aprovado.

De qualquer modo, parece-nos que a proposta do Distrito Industrial aparece pela primeira vez na imprensa local, com a realização do já citado Primeiro Seminário de Avaliação do Plano Diretor de Desenvolvimento Integrado de Franca, realizado pela Prefeitura em 26 de janeiro de 1969, apenas cinco dias antes de Hélio Palermo transmitir o cargo para seu sucessor, José Lancha Filho. O assunto pouco foi discutido nos anos seguintes, até a apresentação da proposta de aprovação do Plano Diretor na Câmara Municipal, no final de 1971. Aqui, torna-se importante lembrar que na reunião em que foi aprovado o projeto de Lei do Plano Diretor Físico, não foram aceitos os aspectos referentes à imediata implantação do Distrito Industrial, que teria prazo de dois anos para ser implantado ${ }^{6}$.

Inicialmente, a área apontada pelo GPI foi descartada, provavelmente por pertencer à principal grupo empresarial de artefatos de borracha da cidade, o poderoso grupo Amazonas, que então estava em grande expansão de sua planta industrial. No mesmo período, o governo do Estado se dispôs a construir um novo aeroporto para a cidade $^{7}$. Com isso, seria liberada a grande área ocupada pelo aeroporto então existente, situado defronte aquela proposta pelo GPI. Ou seja, uma área próxima à cidade, plana, servida por rodovia pavimentada e ferrovia, basicamente com os mesmos atributos daquela área estudada inicialmente. Com isso, o governo Lancha Filho adquiriu outra grande área limítrofe ao velho aeroporto, praticamente duplicando sua área.

Em sua exposição de motivos à Câmara para apresentar o projeto de lei de aquisição da área, em ofício datado de 14 de agosto de 1972, Lancha Filho afirma que

como é do conhecimento dessa Egrégia Câmara, um dos principais pontos do Plano Diretor de Desenvolvimento Integrado ou do Plano Diretor, como é mais popularmente conhecido, é o que se refere ao Distrito Industrial, isto é, a área onde deverão ser instaladas as indústrias locais, a exemplo, aliás, do que já vem sendo feito em diversos municípios paulistas e brasileiros: Jundiaí, Ribeirão Preto, Bauru, etc. A área escolhida para o Distrito Industrial localiza-se num ponto privilegiado, em terreno praticamente de topografia plana, nas proximidades do trevo que demanda São José da Bela Vista, ao lado do atual aeroporto ${ }^{8}$.

\footnotetext{
${ }^{5}$ COMÉRCIO DA FRANCA, 26 de fevereiro de 1965, p.8.

${ }^{6}$ COMÉRCIO DA FRANCA, 29 de dezembro de 1971, p.12.

${ }^{7}$ COMÉRCIO DA FRANCA, 16 de setembro de 1972.

${ }^{8}$ Dados extraídos do ofício PJ-17/72, de 14 de agosto de 1972, Projeto de Lei 57/72, Câmara Municipal de Franca.
} 
Ainda no mesmo ano, através da lei 2.100, de 21 de setembro de 1972, o Executivo foi autorizado a desapropriar uma gleba para implantação do Distrito Industrial de Franca. No dia 3 de outubro, o Município de Franca, utilizando a lei, fez lavrar a escritura de compra da gleba, nos seguintes termos:

O Município de Franca, autorizado a expropriar, por via amigável, para a instalação do DISTRITO INDUSTRIAL DE FRANCA, nos termos da lei já em vigor, o seguinte imóvel de propriedade deles outorgantes: uma gleba de terras, situada na Fazenda Santa Cecília, situada neste distrito, município e comarca de Franca, imediações do aeroporto local, com a área de 120, 73,00 hectares9.

Além da desapropriação da área, no entanto, Lancha pouco tempo teve para fazer algo mais. Apenas um estudo inicial para ocupação da área, incluindo uma nova estação ferroviária, foi desenvolvido em seu governo. O retorno de Hélio Palermo em 1973, no entanto, se não trouxe continuidade efetiva ao processo de implantação do Distrito, trouxe o início de discussões acirradas sobre sua necessidade.

Logo no início do governo de Hélio, o vereador arenista Antônio de Freitas Diniz dizia que a instalação do Distrito Industrial não poderia mais ser adiada, os curtumes estavam interessados em sua construção por conta da poluição no córrego do Cubatão. Segundo ele, "a criação e implantação do Distrito Industrial é uma necessidade imperiosa, para disciplinar o crescimento de nosso parque fabril sem trazer embaraços de qualquer espécie à população. Os próprios industriais estão interessados na localização do Distrito Industrial. Trata-se do local mais apropriado para as obras, pois além de oferecer condições fáceis para ser dotado de infra-estrutura, água, energia, asfalto, naquele setor a corrente dos ventos é em sentido contrário à cidade. Este último aspecto é importante para evitar-se o problema da poluição do ambiente, já bastante acentuada em nossa cidade, em face dos problemas dos curtumes na marginal do Cubatão." ${ }^{10}$.

Em novembro de 1973, o mesmo vereador condenou a omissão na peça orçamentária enviada por Palermo à Câmara dos recursos destinados à implantação do Distrito Industrial ${ }^{11}$. No final de dezembro, foi a vez do único vereador emedebista na Câmara Municipal, Milton José Baldochi, criticar o governo de Palermo sobre a ausência de ações visando implantar o Distrito Industrial, alegando que a infra-estrutura do Distrito já deveria estar pronta, conforme previa o Plano Diretor. Segundo Baldochi, “o prefeito também é industrial e sabe que o crescimento desordenado da cidade, com fábricas se espalhando a esmo, acabará provocando estrangulamentos e gastos absurdos"12. Além disso, pesquisadores da universidade local (UNESP) começavam também a cobrar do governo municipal a implantação do Distrito ${ }^{13}$.

\footnotetext{
${ }^{9}$ Transcrição da escritura, matriculada sob n.29.672, no Cartório de Registro de Imóveis e Anexos de Franca.

${ }^{10}$ DIÁRIO DA FRANCA, 19 de abril de 1973, p. 3

${ }^{11}$ DIÁRIO DA FRANCA, 27 de novembro de 1973, p.3

${ }^{12}$ DIÁRIO DA FRANCA, 21 de dezembro de 1973, p.12

${ }^{13}$ Ver artigos no DIÁRIO DA FRANCA do professor Cláudio Vasques, "Razões para implantar o Distrito Industrial”, de 24 de dezembro de 1973, e "7 Fortes razões que obrigam a instalar o Distrito Industrial", de 24 de dezembro de 1974 .
} 


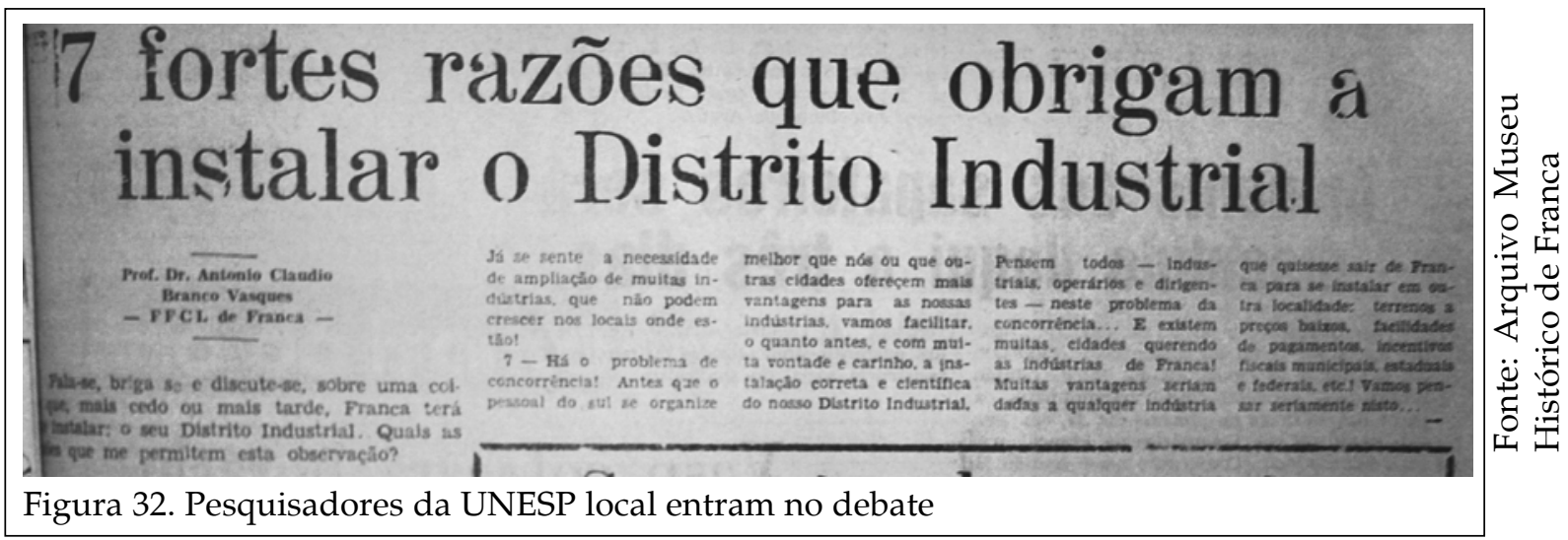

O agravamento da poluição ambiental gerada pelas atividades industriais dos curtumes na região central adquire força, embasado nas reclamações populares. A Fundação Estadual de Saneamento Básico - FESB notificou os curtumes, em 1974, para construir seus sistemas de tratamento de esgotos industriais, sob pena de multas. Tal fato gerou posicionamento da imprensa, que se aproveitou do fato para cobrar a implantação do Distrito com alternativa para solucionar a questão ambiental ${ }^{14}$.

\section{Curtumes envenenam a cidade}

Começaram as pressões legais contra os curtumes que atiram seus residuos aos córregos e contribuem para envenenar as águas e o ar de Franca: O Fundo Estadual de Saneamen to Básico (FESB) já notificou alguns curtumeiros e concedeu-lhes certo prazo para construírem sistema de tratamento de seus esgotos industriais.

Tal informe, contido em nota oficial da Prefeitura, não esclarece os prazos concediclos nelo FESB. Mas observa que o dr. Luiz do Couto Rosa. chefe da Assessoria de Planejamento da Prefeitura, comentou, tão logo tomou conhecimento das notificaçôes: "Isto confirma nossas poderacões, não só quanto ì poluicão das águas, .como também quanto à poluição atmosférica"

A prónria nota oficial admite que a $\mathrm{Li}$ do Plano Diretor Físico, aprovada em 1972 prevê com prioridade a transferência d-s $\mathrm{cu}$ tumes para o Distrito Industrial. Mrs se linnita a adiantar que "já foram aćquiridos mais de 100 hectares em local previamente pesqui-

\section{Pedras contra o Fusca}

sado para sua implantação", e que o plano "deve ser encaminhado à apreciação do Prefeito dentro de poucos dias".

Depois disso, segundo o dr. Couto Rosa, "se diligenciará junto aos curtumeiros, para que seja efetivada a transferência", sem no entanto estabelecer datas especificas, enquanto já se pensa em solicitar ao FESB a dilatarão do prazo concedido pelas notificaçóes.

Tal injeção de ânimo na Administraçâo Municipal produzida pelo FESB contrasta com a veemente atuarão do vereador Antônio Marcos Kaluf, quando era lider do Prefeits na Câmara: Fazendo-se também porta-voz das empresas, ele justificava a demora na implantacão do Distrito garantindo que as fábri cas e curtumes ainda não se encontravam bas tan'e sólidos para gastarem com a fretagem de Ônibus destinados ao transporte dos operários. E garantia que a Prefeitura nấo poderia tomar de afogaditho a iniciativa de implantar o Distrito, por falta de verbas capazes de cis. tearem a infra-estrutura - sistema de água e esgotos na área de mais de cem hectares iá adquiridos.

Figura 33. Reclamações contra a indústria curtumeira repercutem na imprensa

A cobrança da implantação do Distrito passa a ser tema recorrente na imprensa, em editoriais e artigos. A imprensa alega que o prefeito Hélio não dedicou a devida importância ao Distrito, relegando-o a segundo plano, afirmando ainda que foi

\footnotetext{
${ }^{14}$ DIÁRIO DA FRANCA, 09 de abril de 1974, p. 3: "Curtumes envenenam a cidade".
} 
justamente na gestão anterior de Hélio que se inculcou a idéia da concentração industrial, quando era estudado o Plano Diretor da cidade, e a aprovação de um projeto de lei do vereador governista José Finardi Garcia, adiando para 1976 as obras, acabaria deixando para o seu sucessor a tarefa ${ }^{15}$.

Porém, foi no governo seguinte, de Maurício Sandoval Ribeiro que o processo realmente começou a deslanchar, com a efetiva integração do empresariado nos trabalhos, dando corpo à proposta. A criação do Plano de Desenvolvimento Industrial - PLADEIN, através da lei municipal n. 2.552, de 16 de novembro de 1978, que era constituído por grupos de trabalho que envolvia o poder público e entidades empresariais, proporcionou o início de ações concretas da administração municipal para implantar o Distrito Industrial. O objetivo do PLADEIN era implantar o Distrito Industrial, a partir dos estudos elaborados por uma Comissão Diretora dividida em três grupos, técnico, jurídico e executivo, com representantes da Prefeitura, da Câmara, de concessionárias de serviços públicos e de entidades empresariais. Caberia à Comissão Diretora planejar, analisar propostas, estabelecer estímulos e emitir pareceres sobre os pedidos de instalação de indústrias no local. No final dos anos 70, a construção de uma subestação de energia elétrica pela concessionária CPFL foi realizada em local anexo ao futuro Distrito, visando atender a futura demanda da indústria. Ao mesmo tempo, empreenderam-se difíceis negociações com o Aeroclube local, que resistia à idéia de desativar o antigo aeroporto, cuja área seria ocupada pelo empreendimento. É Maurício Sandoval Ribeiro, então prefeito da cidade, quem relata:

Eu tinha um conhecimento muito superficial (do Plano Diretor), a própria equipe que nós montamos é que fez o estudo, depois que eu tomei posse, e foi rápido, acredito que uns três meses eles tomaram conhecimento, do Plano. E começamos a juntar, pelo Distrito Industrial, já começamos a entrar em entendimento com o Aeroclube, no sentido de eles saírem de lá, mesmo por que praticamente já tinha sido inaugurado o novo aeroporto, faltavam os asfaltamentos ali da parte da estação, que nós fizemos toda aquela parte, ajardinamento, a prefeitura fez, eles inauguraram sem acabar aquilo ali, peguei e pus as máquinas da prefeitura, mesmo sem convênio, sem nada, fizemos toda a frente da estação, o fundo, arborizamos, gramamos, depois fizemos, v. lembra, fizemos o hangar para o Aeroclube e asfaltamos até a pista do hangar, para os aviões (...) o Morandini veio para a Administração, ele estava na Administração e depois foi para o Planejamento, eu sei que ele atuou muito foi na área do Distrito Industrial, até o nome Dinfra foi escolhido por aquela equipe que estava lá, que participou todos os segmentos da cidade, outros setores, né, da cidade, que acabaram escolhendo o nome Dinfra, eu lembro que o Morandini entrou no meu gabinete, e disse, prefeito, nós escolhemos já o nome, Dinfra, você aprova? Eu disse tá ótimo, Distritos Industriais de Franca S.A., até isso não foi mudado, quando o Sidnei assumiu, o nome e toda aquela estrutura ${ }^{16}$.

\footnotetext{
15 Ver editoriais do DIÁRIO DA FRANCA, 03 de março, p.2 e 05 de dezembro de 1974, p.2 e matéria do dia 01 de dezembro de 1974, p. 3, "Äté quando a cidade ficará sem seu Distrito Industrial?".

${ }^{16}$ Entrevista gravada concedida ao autor, em 25/01/2005.

${ }^{17}$ O Plano Diretor não explicitava a criação de uma empresa, embora mencionasse a necessidade de ações no campo jurídico. A constituição do DINFRA foi, portanto, uma sugestão surgida no âmbito do PLADEIN.
} 
Ao mesmo tempo em que as questões institucionais eram objeto de estudos, como a formulação de um projeto de lei para criação de uma empresa estatal ${ }^{17}$ que seria responsável pelo Distrito Industrial, a Secretaria de Planejamento tomou medidas no sentido de efetuar a regularização fundiária da gleba, já que as descrições das escrituras não correspondiam ao terreno efetivamente existente. Também foi iniciado o projeto urbanístico, todo ele desenvolvido ainda durante a gestão de Maurício Sandoval. A divulgação institucional do Distrito Industrial de Franca, mesmo sem ainda existir de fato, já ocorria em eventos estatais destinados à atração de investimentos para as cidades do interior ${ }^{18}$.

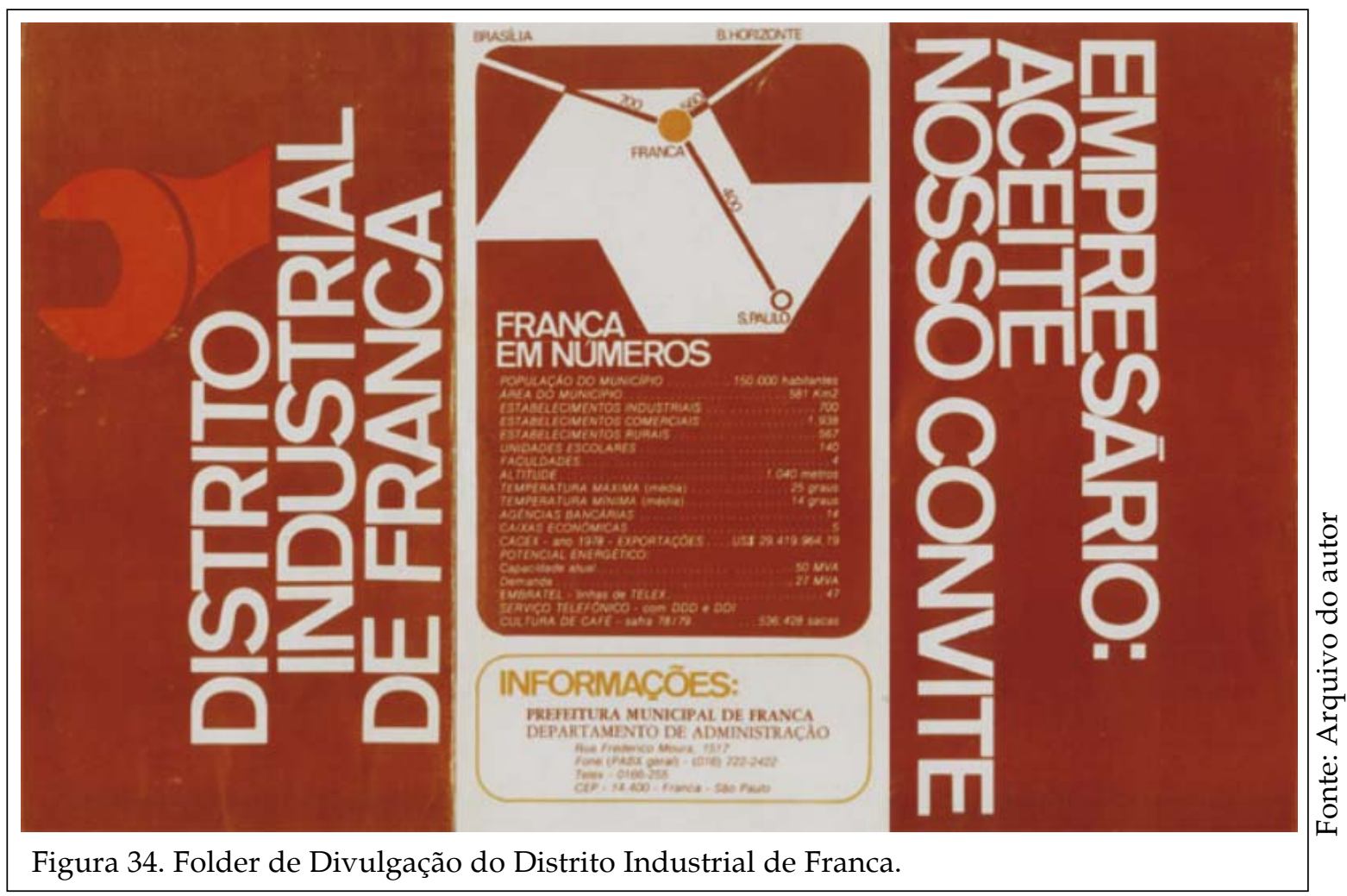

No final de sua gestão, em 1982, a avenida Santos Dumont, que dava acesso ao antigo aeroporto, foi totalmente pavimentada com duas pistas, com o objetivo de garantir acesso ao local. Tais investimentos permitiram ao sucessor de Maurício Sandoval Ribeiro (então no PDS), Sidnei Franco da Rocha (PMDB) tomar as medidas necessárias ao início das obras do loteamento industrial e a criação legal do DINFRA S.A, empresa de economia mista que seria responsável pelo Distrito, com 99,9\% de suas ações pertencentes à Municipalidade.

A partir de 1983, a proposta do Distrito Industrial entrou em outra fase. Em sua proposta de governo, Sidnei Franco da Rocha apresentava um diagnóstico econômico e social da cidade preocupante, afirmando que

\footnotetext{
${ }^{18}$ Ver folder (figura 34) de divulgação do Distrito Industrial de Franca, julho de 1980, produzido pela Prefeitura, para veiculação na Feira dos Municípios Paulistas, realizada no Anhembi, em São Paulo.
} 
não se discute mais as dificuldades que temos tido para a criação de novos empregos. Dia a dia cresce assustadoramente o número de desempregados (...) assim, propomos as seguintes providências imediatas, para que, ao menos no âmbito municipal, amenizemos o problema:

- Urgente implantação do Distrito Industrial, com o desenvolvimento de um amplo estudo para se atrair mais indústrias para a cidade;

- "Revisão do Plano Diretor para edificações, com uma nova legislação que abra espaço para a indústria da construção civil em geral, inclusive a obras de grande porte (edifícios). (PARTIDO DO MOVIMENTO DEMOCRÁTICO BRASILEIRO, 1982:2)

Para reforçar a idéia do Distrito Industrial, a proposta detalhava como isso seria feito:

implantação do Distrito Industrial, de maneira gradativa e segura, com base em uma legislação que atenda, antes de tudo, a realidade industrial de Franca. A urgência dá-se em razão do seguinte:

1. necessidade de mudança imediata daquelas empresas que carecem de um espaço físico mais amplo e funcional;

2. atrair para Franca indústrias correlatas à do calçado, visando sempre melhorar a produtividade de nosso parque fabril; atrair indústrias produtoras de materiais na área da construção civil, principalmente a indústria de materiais básicos; ampliar, enfim, nosso parque industrial, hoje já bastante significativo. (PARTIDO DO MOVIMENTO DEMOCRÁTICO BRASILEIRO, 1982:15)

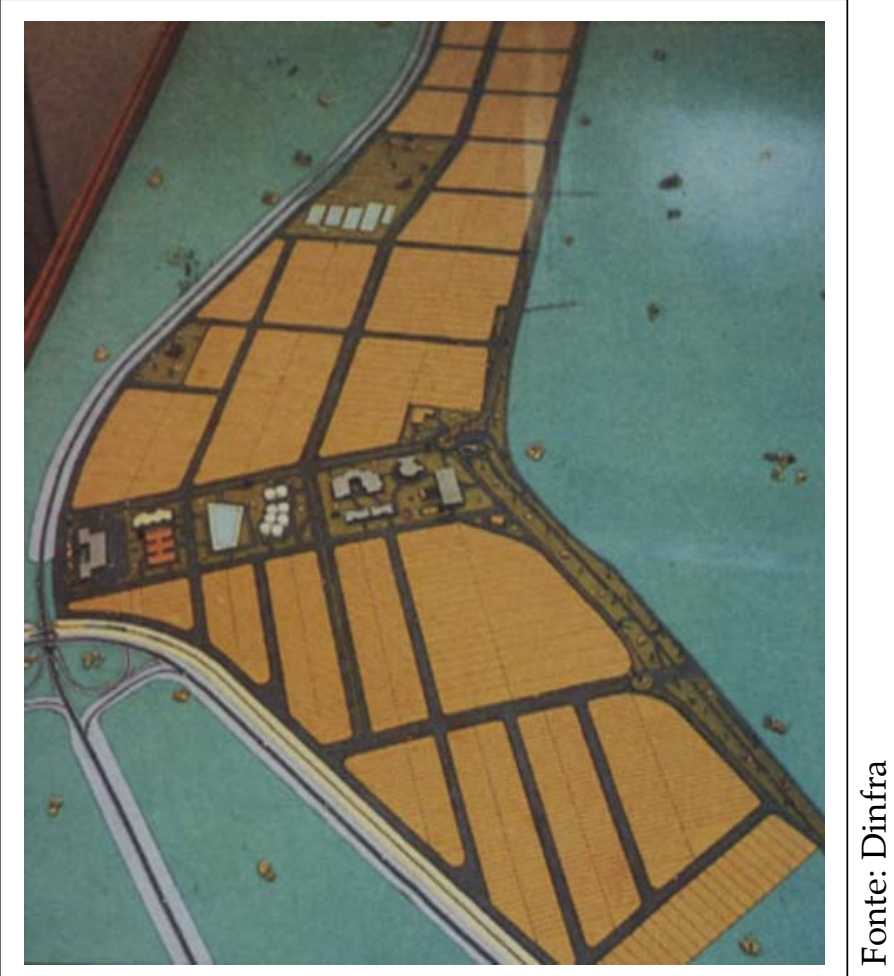

Figura 35. Maquete do Distrito Industrial de Franca. 


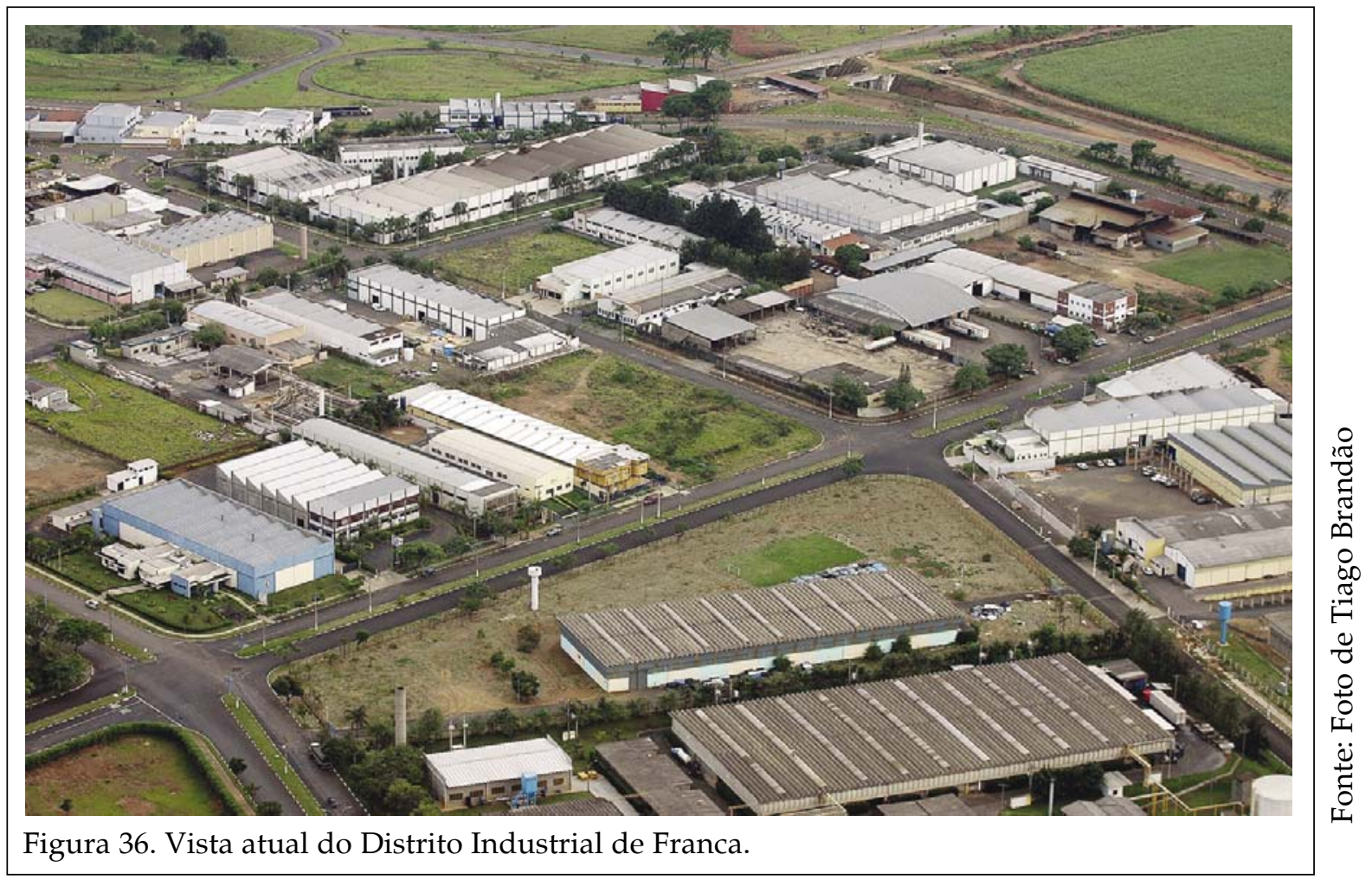

Dentre outros aspectos, a proposta de Sidnei Franco da Rocha também previa "a implantação do anel viário, com a conclusão das avenidas marginais e projeção de novo acesso à cidade e a racionalização do tráfego urbano". (PARTIDO DO MOVIMENTO DEMOCRÁTICO BRASILEIRO, 1982:10)

Tais referências explícitas em um programa de governo vencedor, 15 anos depois do início da sua elaboração, parece trazer evidências bastante fortes que o Plano Diretor, enquanto compromisso de governo, se introduziu como elemento importante no discurso político local, como se fosse um componente essencial da modernização da cidade e de sua administração pública, dando suporte aos interesses expressos pelo mais importante setor industrial local. Ofato é que o governo de Sidnei Rocha tomou todas as iniciativas visando implantar o Distrito Industrial, aproveitando os estudos elaborados no governo anterior. Aprovou, implantou e consolidou a empresa de economia mista responsável pelo seu gerenciamento, o DINFRA S.A., cuja constituição havia sido autorizada pela lei municipal n. 2.863, de 24 de junho de $1983^{19}$. A empresa coordenou as obras de implantação do empreendimento e a comercialização dos imóveis, sendo que as primeiras empresas se instalaram na área a partir de 1984.

Evidente que a implantação do Distrito não atendia apenas as necessidades de modernização e expansão do setor industrial: de outro lado, as exigências ambientais para instalação de novas indústrias no estado de São Paulo se intensificaram a partir de 1976, quando entrou em vigor a lei que criou a CETESB, companhia estadual criada para fiscalizar os parâmetros ambientais para regular as atividades industriais. Para culminar o interesse no processo de implantação do Distrito Industrial, havia também a localização da antiquada indústria coureira em áreas centrais da cidade, que gerava vigorosas e constantes reclamações da população contra a poluição do ar e das águas pelos curtumes. Era também uma oportunidade para a relocalização e modernização do setor, liberando áreas nobres e centrais para novos empreendimentos imobiliários, não previsto pelo Plano Diretor.

${ }^{19}$ A empresa DINFRA entrou em processo de liquidação a partir de 2005, sob o novo governo de Sidnei Rocha (PSDB) e Ary Balieiro (PTB). 


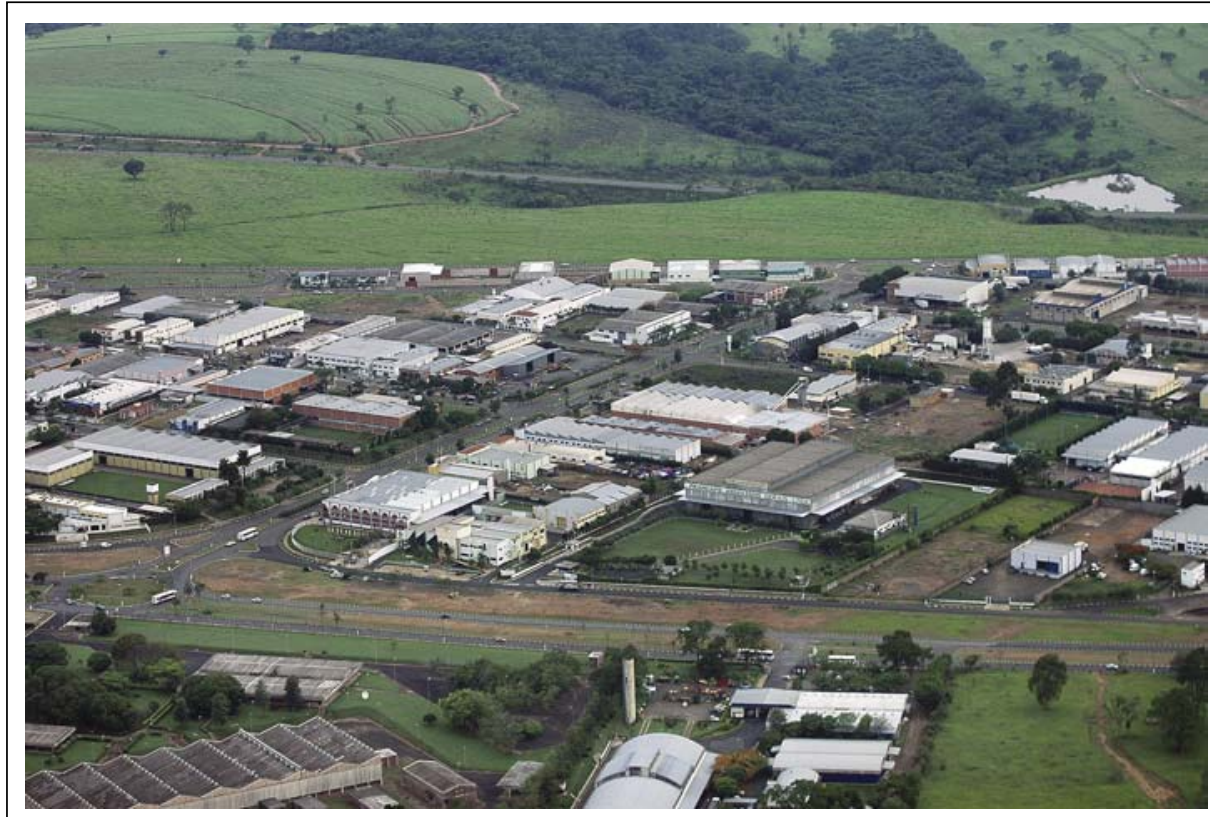

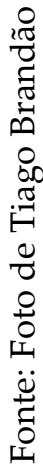

Figura 37. Vista atual do Distrito Industrial de Franca.

INTERVENÇÕES NO SISTEMA VIÁRIO: PREPARANDO A CIDADE PARA SUA EXPANSÃO HORIZONTAL

O Plano Diretor propunha um expressivo conjunto de intervenções viárias, desde a abertura e consolidação de novas vias e soluções para locais de maior tráfego de veículos, visando equacionar e melhorar a circulação intra-urbana, conforme já sugeria o Diagnóstico. Os locais apontados são:

- avenida marginal ao córrego do Cubatão com Champagnat, Saldanha Marinho e Major Nicácio (avenida dr. Ismael Alonso y Alonso)

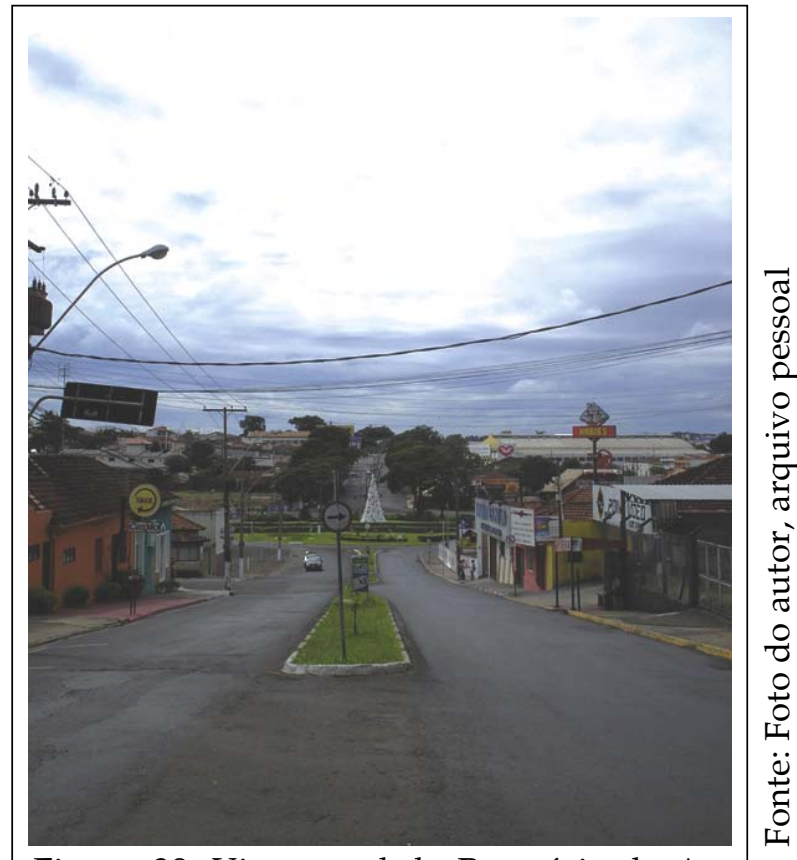

Figura 38. Vista atual da Rotatória da Av. Ismael Alonso com Av. Champagnat. 


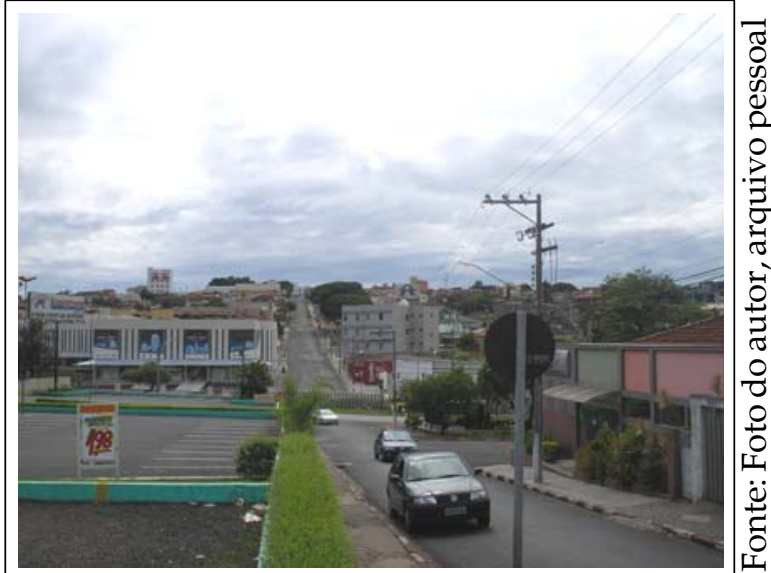

Figura 39. Vista atual da Rotatória da Avenida Ismael Alonso com Rua Saldanha Marinho.

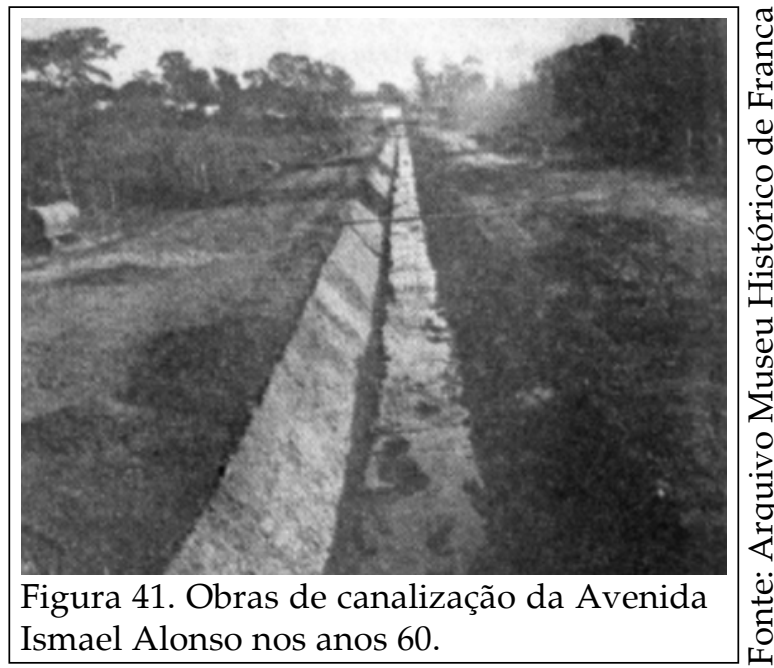

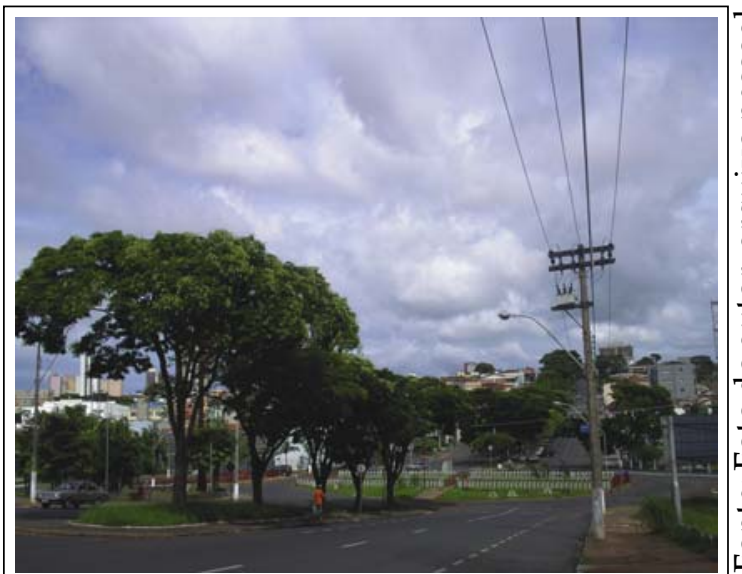

Figura 40. Vista atual da Rotatória da Avenida Ismael Alonso com Avenida Major Nicácio.

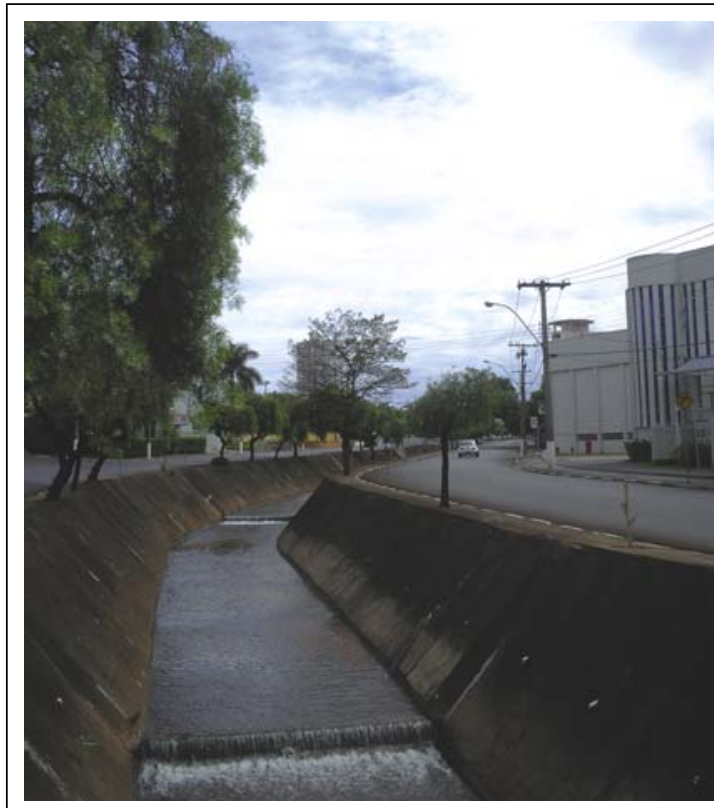

Figura 42. Trecho canalizado da Avenida Ismael Alonso.

Esta avenida teve seu primeiro trecho iniciado em 1964, logo no início da gestão de Hélio Palermo. Nos dois anos seguintes, os trabalhos prosseguiram, até que em 1966 foi possível concluir um primeiro trecho de 500 metros. Foi inaugurada em 1967 por Hélio Palermo, recebendo a denominação de avenida dr. Ismael Alonso y Alonso (um médico, ex-prefeito da cidade e falecido na época das obras), e somente foi concluída em toda sua extensão no início dos anos 1990. Na verdade, o trecho previsto pelo Plano foi ampliado nos dois sentidos, ao longo de todo o curso d'água situado na malha urbana.

Os três cruzamentos desta avenida apontados pelo Plano como sendo necessária uma intervenção, receberam uma praça rotatória para disciplinar o fluxo de veículos, a partir de 1968. Estes locais, por sua importância no tráfego local, vem sofrendo seguidas remodelações, sendo a última intervenção de maior porte, que ampliou a praça rotatória existente, executada no cruzamento com a avenida Champagnat, que mereceu desapropriações de grande vulto, em 1995, no governo de Ary Balieiro.

- avenida Major Nicácio com avenida Getúlio Vargas;e Brasil com Getúlio Vargas 


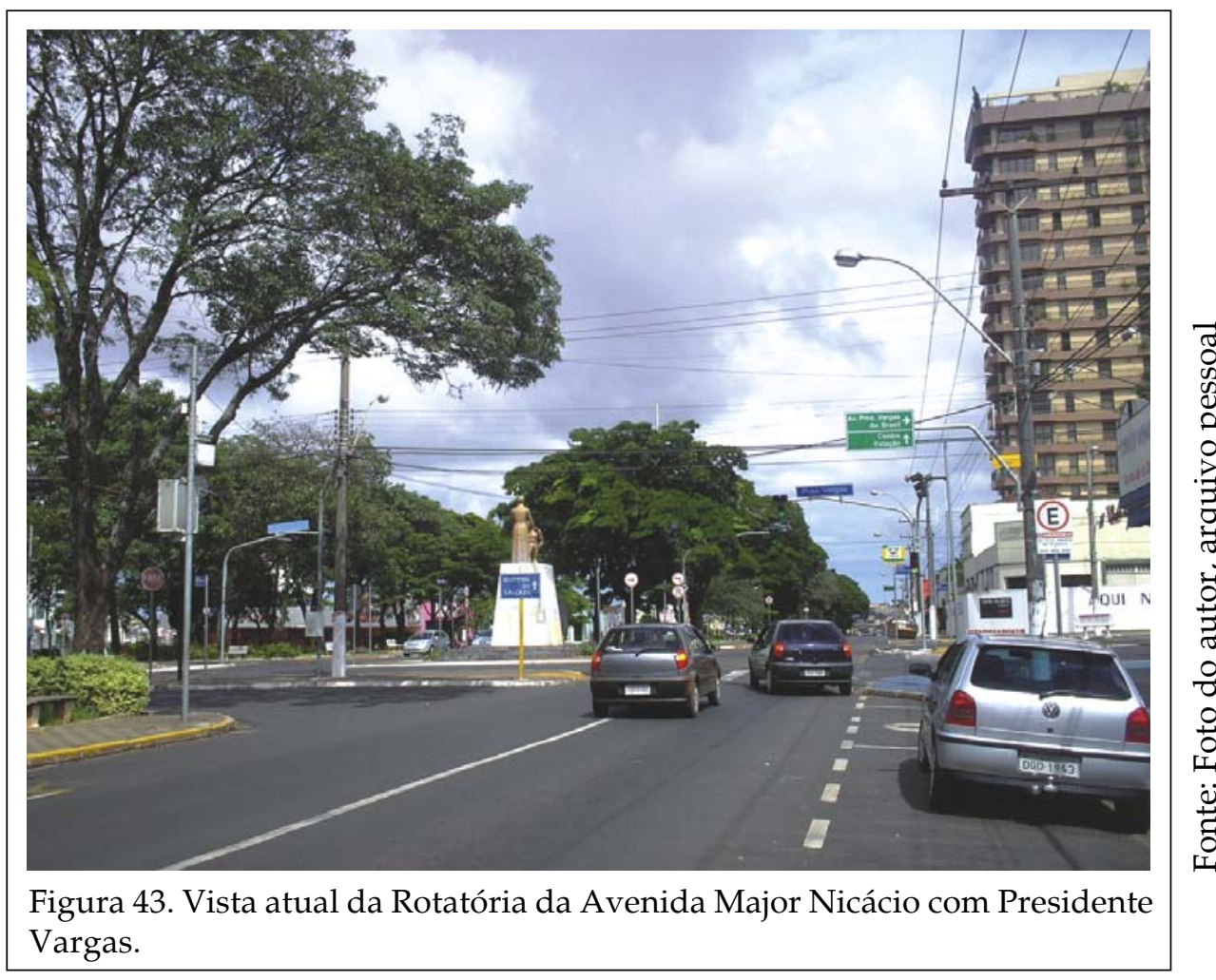

O cruzamento da Major Nicácio com Getúlio Vargas foi objeto de uma grande intervenção em 1988, no governo de Ary Balieiro, que incluiu o remodelamento da praça João Mendes e melhorias em seu paisagismo; já entre as avenidas Brasil e Getúlio Vargas, não houve intervenção significativa, apenas semafórica.

- avenida marginal do córrego do Bagres com ruas Batatais, General Telles, General Carneiro, General Osório, Evangelista de Lima, Afonso Pena, Amália Antunes Pinheiro (avenidas Hélio Palermo e Antônio Barbosa Filho)

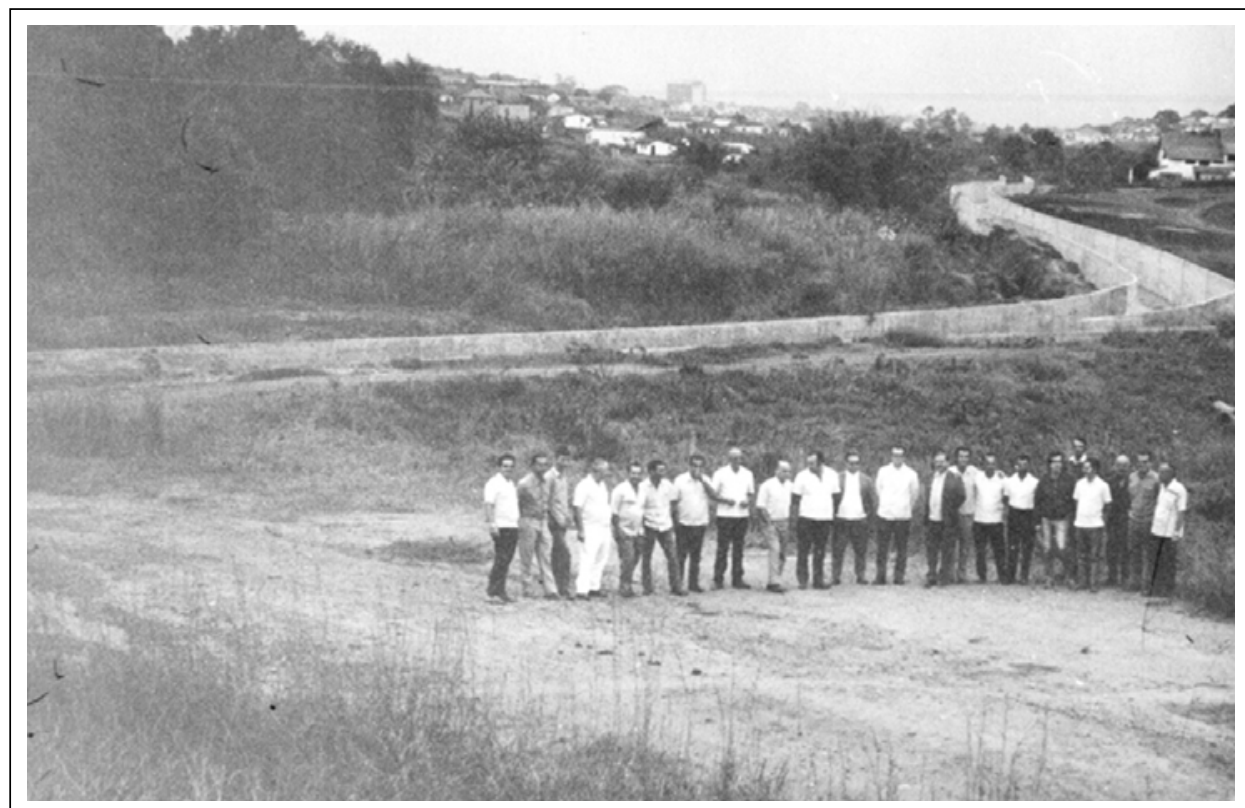

Figura 44. Lancha e membros de sua equipe visitam obras de canalização do córrego dos Bagres 
A avenida, que teve seus primeiros trechos de córrego canalizado em 1968 por Hélio Palermo, recebeu inicialmente a denominação de Robert Kennedy. Após o falecimento de Hélio Palermo, em 1977, a avenida teve sua denominação alterada para o nome do ex-prefeito. Como a avenida era truncada pelo Vale dos Bagres até o início dos anos 1990, o outro trecho recebeu a denominação de avenida Costa e Silva, posteriormente substituída pelo nome do ex-prefeito Antônio Barbosa Filho. Suas obras foram realizadas por partes, até os anos 1990.

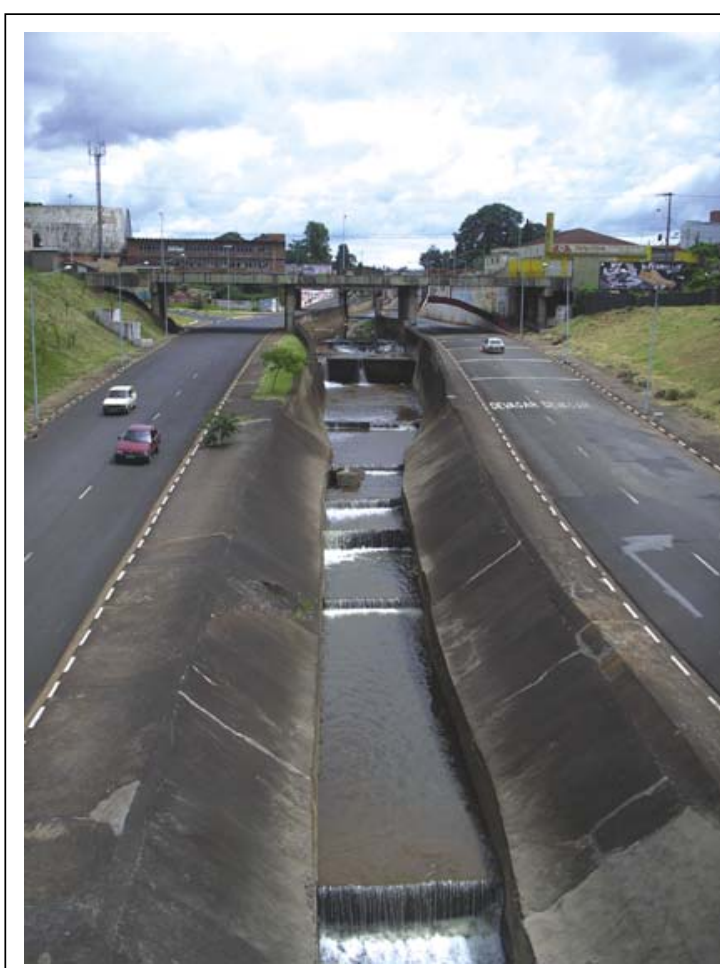

Figura 45. Canalização do córrego dos Bagres na avenida Hélio Palermo, após destruição da cachoeira.
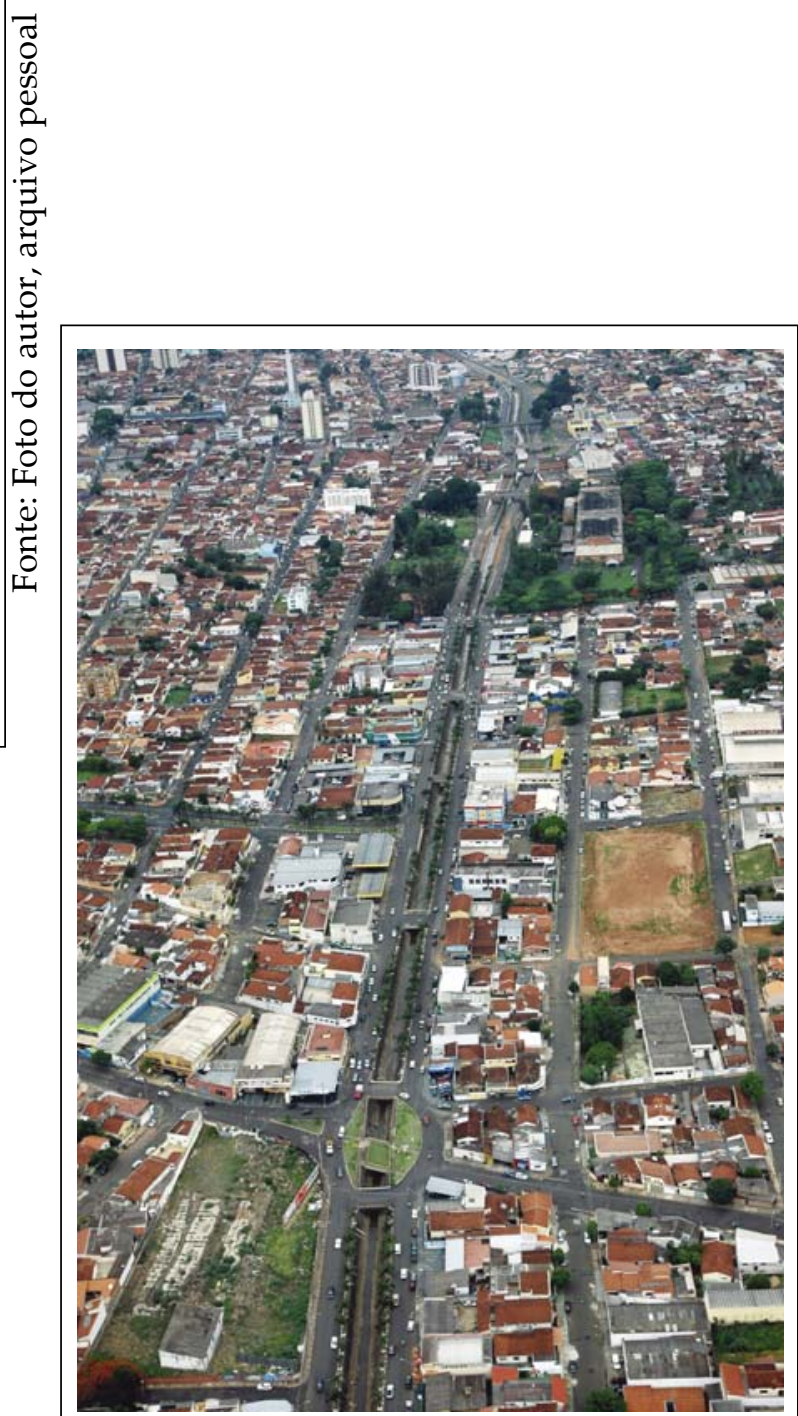

Figura 46. Vista atual da avenida Major Nicácio e rotatória com avenida Hélio Palermo. 
Foram construídas praças rotatórias no cruzamento com as ruas Afonso Pena e com a avenida Amália Antunes Pinheiro. No cruzamento das ruas Batatais, General Telles, General Carneiro e General Osório, foram construídos viadutos que permitem o cruzamento em nível diferenciado. Na rua Evangelista de Lima, foi construída uma ponte em nível, regulada por semáforo.

- avenida marginal do córrego dos Bagres com avenida Getúlio Vargas;

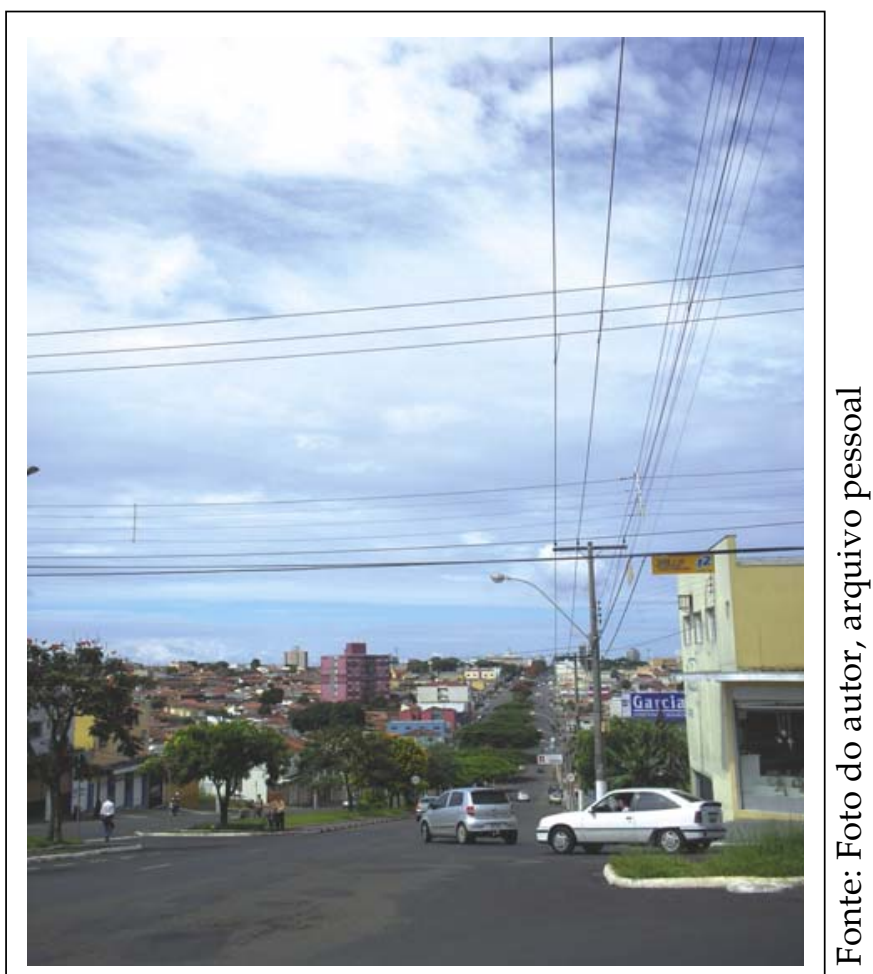

Figura 47. Vista atual do cruzamento da avenida Presidente Vargas com avenida D. Pedro I.

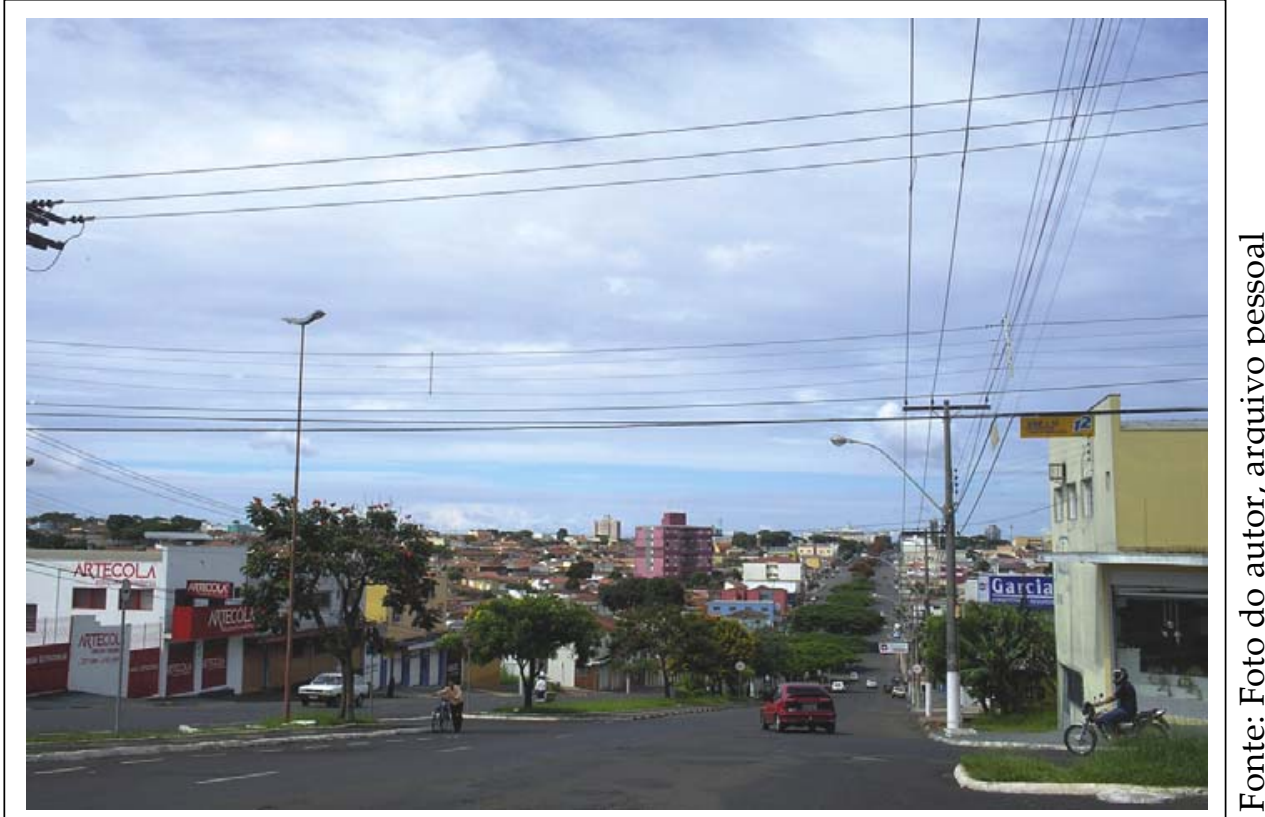

Figura 48. Vista atual do cruzamento da Av. Presidente Vargas com D.Pedro I. 
O cruzamento da avenida Hélio Palermo com avenida a Getúlio Vargas recebeu dois viadutos nesta última, que viabilizaram um passagem em níveis diferenciados.

- rua G com rua São Benedito;

- cruzamento da rua Evangelista de Lima com a rua Carlos de Vilhena

- cruzamento da avenida Rio Branco com rua Cássia

Estes cruzamentos não receberam qualquer modificação significativa, mesmo porque com o decorrer dos anos, perderam importância em função da criação de alternativas de circulação por novas avenidas e vias.

Uma outra proposta era a travessia dos trilhos da estrada de ferro Mogiana, então em atividade, em dois pontos: um através da rua General Telles e outra no prolongamento da rua Evangelista de Lima. O ramal ferroviário de Franca, no entanto, foi desativado definitivamente em 1977, o que motivou a Prefeitura a substituir os trilhos por uma avenida, chamada da Integração. Em ambas as vias, foi possível executar praças rotatórias para ligar os lados da cidade, até então divididos pela ferrovia.
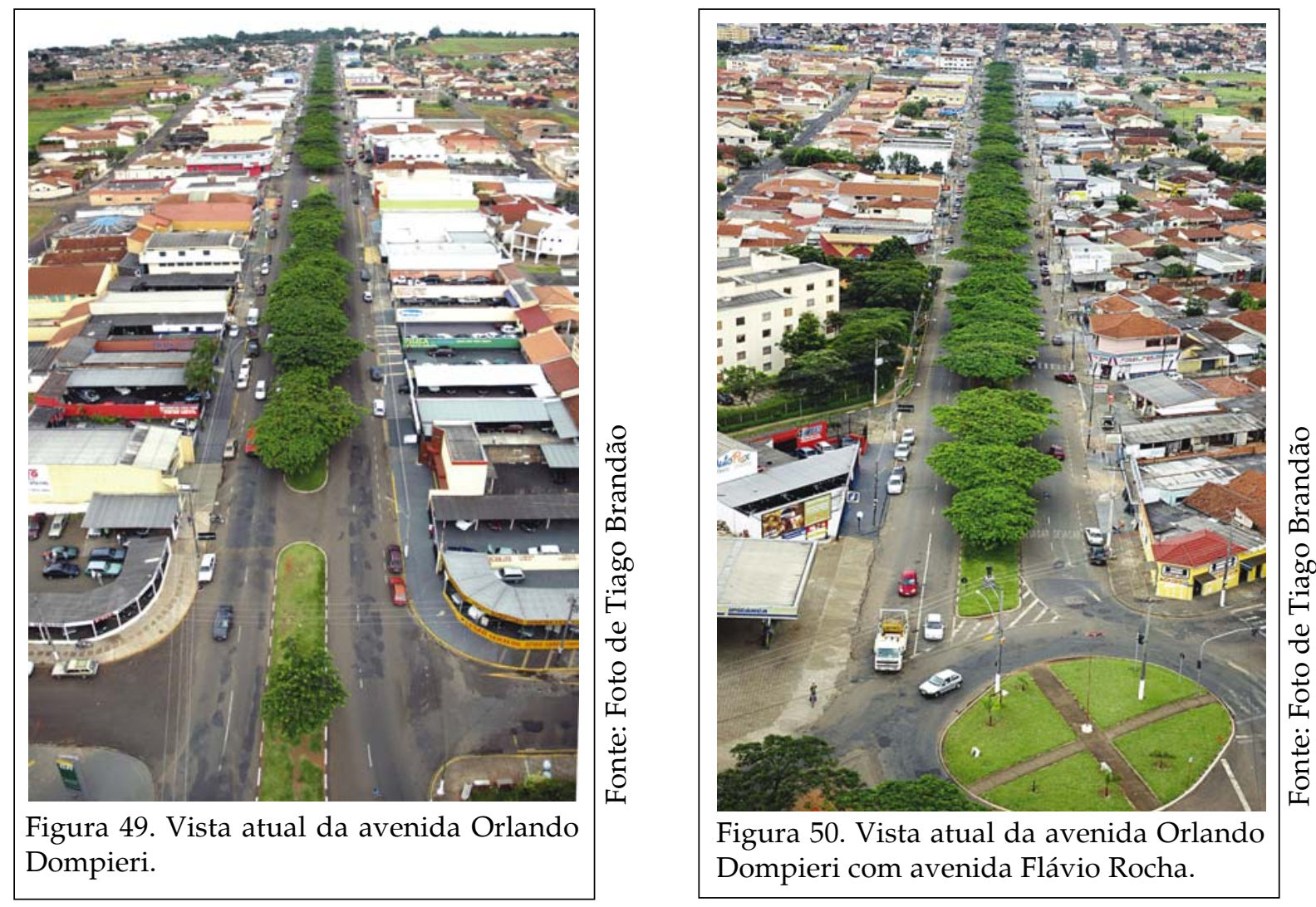

Outra via importante que foi aberta no início dos anos 1980, prevista pelo Plano, foi a atual avenida Orlando Dompieri (antiga Amélia Antunes Pinheiro), que permitiu a interligação da cidade então existente com a região de subúrbio onde foi construído o Parque Habitacional Vicente Leporace, empreendimento iniciado pela CECAP (hoje CDHU) no final dos anos 70, que abriga hoje três mil unidades habitacionais de baixa renda. Sem esta via, seria inacessível e inviável a ocupação da região, situada do outro 
lado da rodovia Cândido Portinari, fora dos limites da área urbana estabelecidos pelo Plano Diretor em 1972.

Desta maneira, pode-se observar que as principais propostas do Plano Diretor para o sistema viário, formado principalmente pelas duas vias de fundo de vale, bem como pela avenida Presidente Vargas, Major Nicácio e Champagnat, foram integralmente construídas e seus principais cruzamentos receberam intervenções físicas e melhoramentos, criando melhores condições gerais de circulação e trânsito automobilístico da cidade e gerando novas possibilidades locacionais de negócios e empreendimentos imobiliários. Estas obras atendem principalmente uma região que se poderia chamar hoje de centro expandido: a colina central e o bairro da Estação, as regiões mais antigas da cidade, cuja ocupação se iniciou no século XIX e hoje as mais densamente urbanizadas, até mesmo porque foram projetadas nos anos 60, quando a cidade ocupava apenas as colinas do centro, Estação e Santa Cruz. Desta maneira, as intervenções se distribuíram por toda a cidade então existente, sem que houvesse um claro privilégio regional em termos de distribuição das obras viárias.

\section{O CENTRO DA CIDADE PARA OS PEDESTRES}

As primeiras experiências de pedestrianização do centro de cidades no Brasil foram desenvolvidas em Curitiba (PR), a partir de 1972. O Plano Diretor da capital paranaense propunha desde a década de 1960 o desestímulo ao uso de carros na região central. Com isso, uma de suas principais vias comerciais, a rua XV de Novembro foi modificada para atender os pedestres e mobiliada com quiosques modulares, novas luminárias, bancos e floreiras, que foi rapidamente absorvida pela população. Para evitar liminares da justiça impetradas pelos comerciantes que eram contrários ao projeto, a obra foi realizada num final de semana de maio daquele ano de 1972 pelo prefeito nomeado, o arquiteto Jaime Lerner, que havia participado da equipe que elaborou o Plano Diretor. Com isso, a prefeitura de Curitiba procurava tornar irreversível o processo de retirada dos veículos particulares do centro da cidade, já que algumas delas já estavam fechadas à circulação de veículos desde o ano anterior. (OLIVEIRA, 2003)

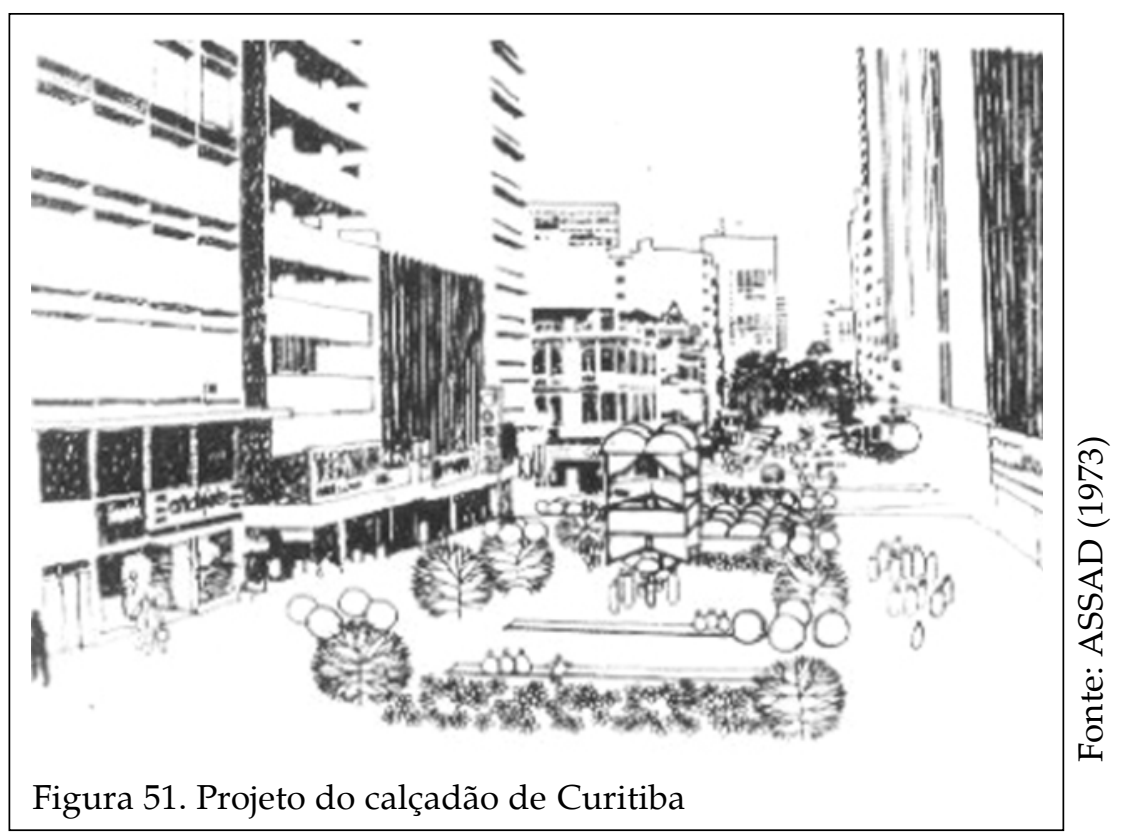


O impacto e o sucesso da iniciativa geraram o desencadeamento de iniciativas similares em dezenas de cidades brasileiras. Segundo a arquiteta Olga Brostein,

"a tendência de privilegiar o pedestre em detrimento do uso exagerado do automóvel prevaleceu também na década de 70, tendo sido incentivada a multiplicação de calçadões. Alguns deles existiam desde o início do século, como a Rua do Ouvidor, no Rio. Outras, antes abertas ao tráfego, já haviam sido transformadas em vias de pedestres, como todas as compreendidas na região conhecida por Saara, uma zona comercial semelhante ao Bom Retiro, em São Paulo. Mas foi a partir de 1970 que a política de implantação de calçadões realmente se intensificou (op. Cit. LEME, M. B.; VENTURA, D.V.B., 2000:55).

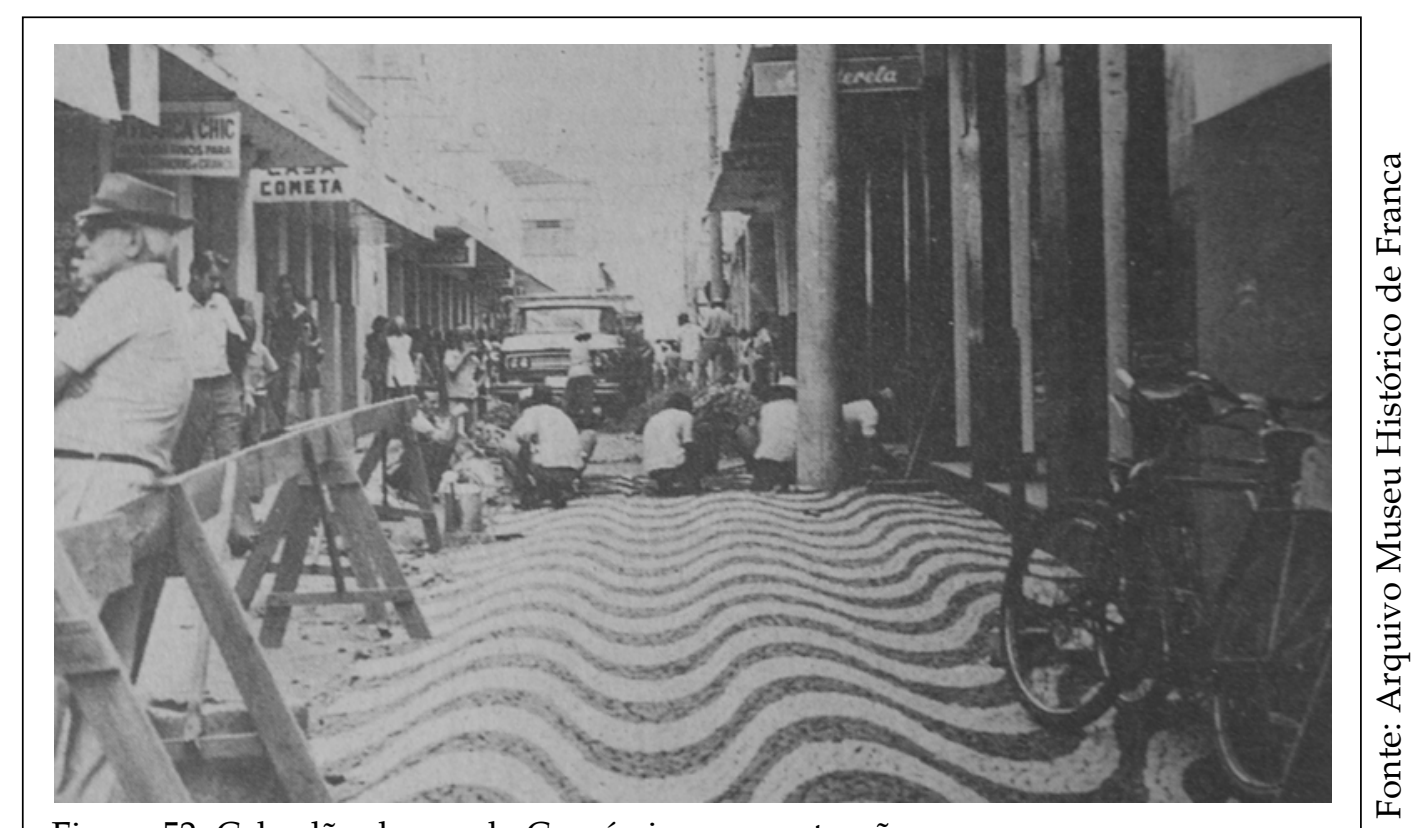

Figura 52. Calçadão da rua do Comércio em construção

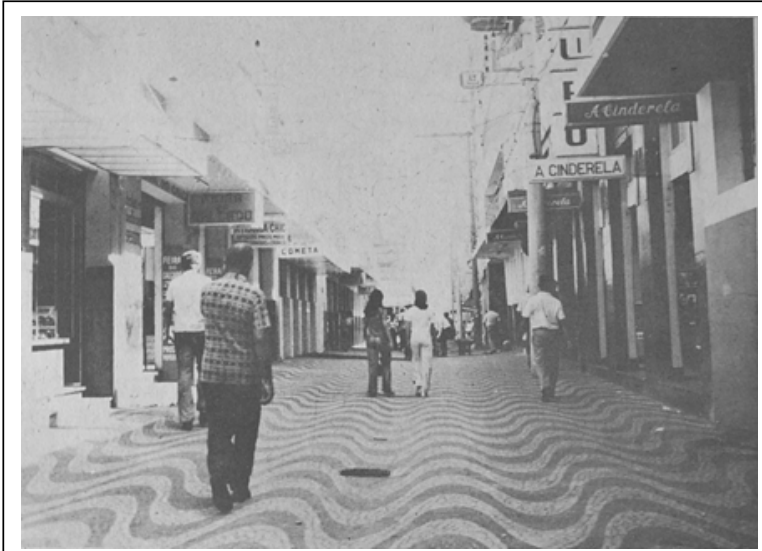

Figura 53. Calçadão da rua do Comércio concluído

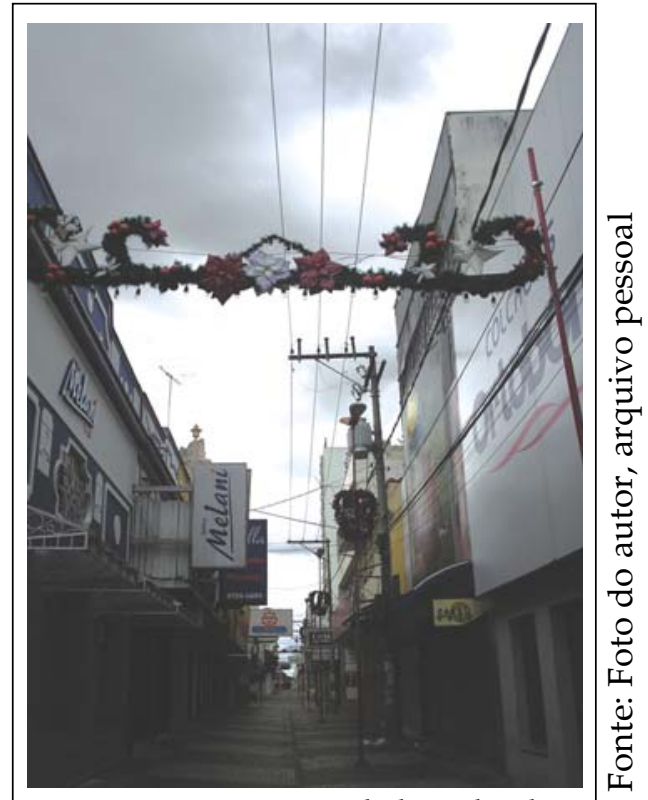

Figura 54. Vista atual do calçadão da Rua do Comércio. 
Em Franca, a primeira experiência foi realizada ainda em 1974, já durante o segundo governo de Hélio Palermo. Embora a proposta do Plano fosse dos anos 1960, sua implantação demonstra que o Plano e sua execução estavam sintonizadas com as idéias urbanísticas em circulação naquele momento e viabilizou-se por causa do sucesso da iniciativa curitibana, a pedido dos próprios comerciantes locais. O primeiro trecho pedestrianizado foi da rua do Comércio, entre as ruas Voluntários da Franca e General Telles. A rua do Comércio já era, à época, uma via estritamente comercial, de reduzidíssimas dimensões de sua caixa de rolamento, com calçadas diminutas e onde apenas dois veículos de pequeno porte podiam circular simultaneamente.

É evidente que a proposta do Plano Diretor, de fechar a região central para o tráfego de veículos particulares fazia parte do debate urbanístico à época, presente nos Planos de outras cidades, mas cuja efetivação teve como força motriz o sucesso do calçadão da rua XV de Novembro em Curitiba. Basicamente, uma questão girava em torno do tema: o congestionamento das regiões centrais das cidades pelo uso exacerbado do automóvel particular e a precariedade do transporte coletivo. O debate à época sobre a "renovação urbana" tinha como pano de fundo o remanejamento de áreas específicas localizadas no interior das aglomerações urbanas: seu objetivo seria

corrigir certos desvios, ou remover anomalias urbanas incomodas ("ghetos" ou quistos sociais; segregação social, favelização, concentração excessiva de habitações chamadas "sub-normais", etc.) que possam ameaçar ou por em risco a eficiência dos mecanismos específicos de produção do espaço urbano e do sistema mais geral da economia (GOMES, C., 1973:55)."

Em Curitiba, a idéia que norteou a implantação do projeto da rua XV, segundo seu autor, vindo do Plano Diretor, foi solucionar aspectos negativos advindos da "invasão descabida do veículo motorizado", e a solução foi o desestímulo ao uso de veículos no centro da cidade. A renovação da rua XV, primeiro passo para a solução do problema, foi

“a retirada dos veículos motorizados e a ligação dos pisos de um lado ao outro e de uma extremidade a outra, unindo a rua central às praças vizinhas num único piso. Com isso, reavemos um grande espaço destinado ao homem, justamente na área mais densa". (ASSAD, A., 1973:112)

O espaço renovado da rua poderia desempenhar funções sociais, de lazer, local de encontro, funções econômicas, políticas e culturais. O aumento do movimento de pedestres nas lojas e estabelecimentos comerciais do lugar, disputando espaço com os carros, e o sucesso do calçadão de Curitiba, propiciaram as condições políticas à Prefeitura de Franca efetuar este primeiro movimento de restrição à circulação de veículos. Em virtude das dimensões reduzidas da rua, a intervenção física restringiu-se à colocação de um piso de pedras portuguesas, com uma paginação diferenciada, luminárias novas e alguns vasos elevados de concreto, que impediam a passagem de veículos de maior porte. O projeto é atribuído ao arquiteto Luiz do Couto Rosa. Ao 
mesmo tempo que fazia essa intervenção, a Prefeitura optou por exigir, nas novas construções, um recuo que permitisse futuramente o alargamento das ruas centrais. No entanto, esta iniciativa não teve conseqüências práticas, uma vez que apenas duas obras (uma na rua do Comércio, outra na rua Saldanha Marinho) obedeceram a regra, sendo logo abandonada a exigência.

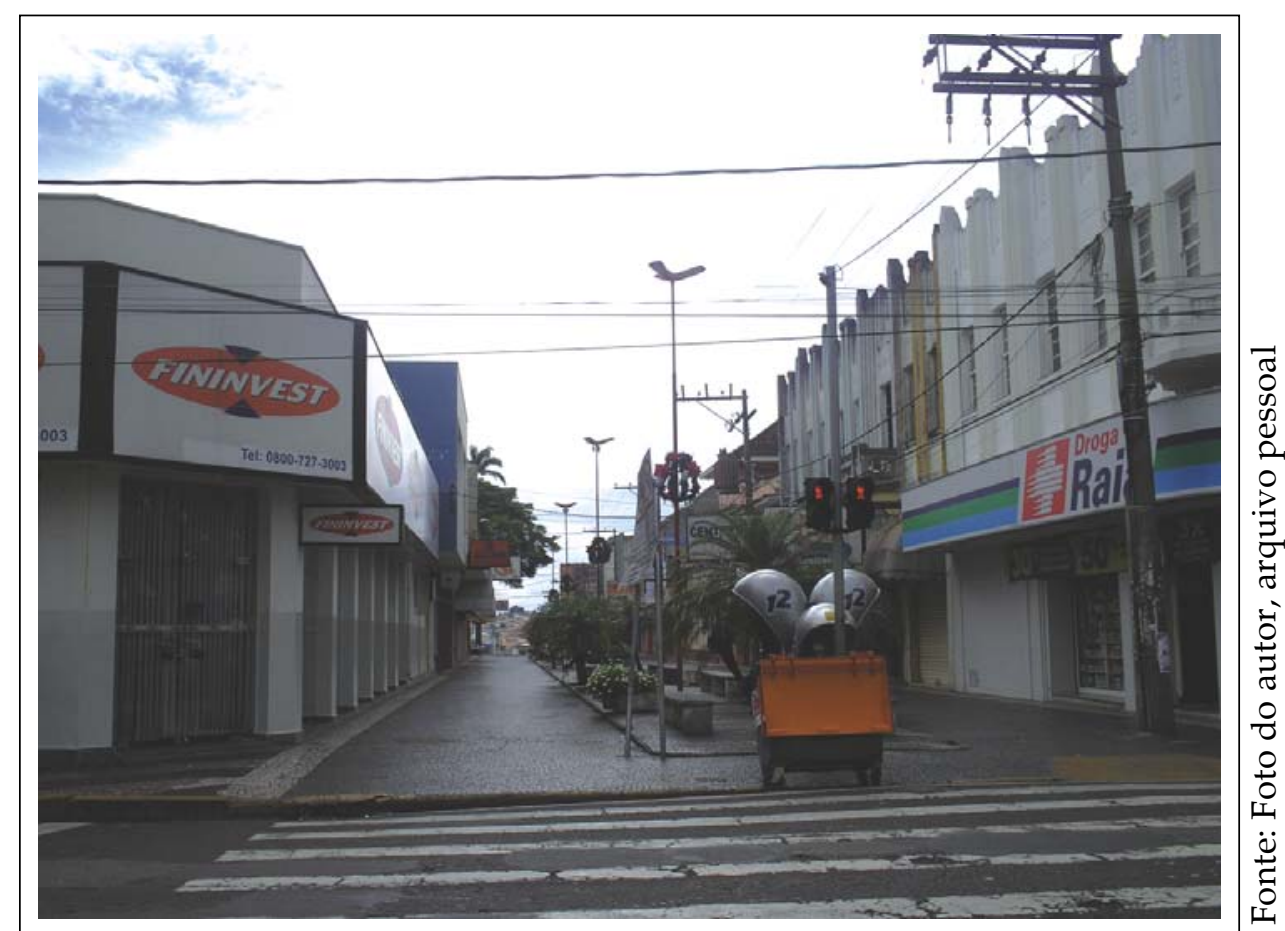

Figura 55. Vista atual do calçadão da rua Mal. Deodoro, construída na segunda gestão de Hélio Palermo.

Apenas em 1975, um novo projeto de Luiz do Couto Rosa para a rua Marechal Deodoro, no trecho situado entre as ruas Major Claudiano e Campos Salles, foi realizado. Como a largura da via era bem mais generosa que a da rua do Comércio, Couto Rosa optou por levantar alguns centímetros o trecho central da via, colocando ali a iluminação, alguns bancos e o ajardinamento, ficando as laterais livres para a circulação dos pedestres.

Mas foi em 1987-88, durante o breve primeiro governo de Ary Pedro Balieiro, vice-prefeito que foi guindado o cargo de prefeito ao substituir Sidnei Rocha, que ocorreu uma grande intervenção na região central. Todo o quadrilátero situado entre as ruas Monsenhor Rosa, Saldanha Marinho, Ouvidor Freire e General Osório teve suas vias fechadas ao tráfego de veículos e transformadas em calçadões, região considerada o "coração comercial" da cidade, além de abrigar casco histórico importante do período cafeeiro. 


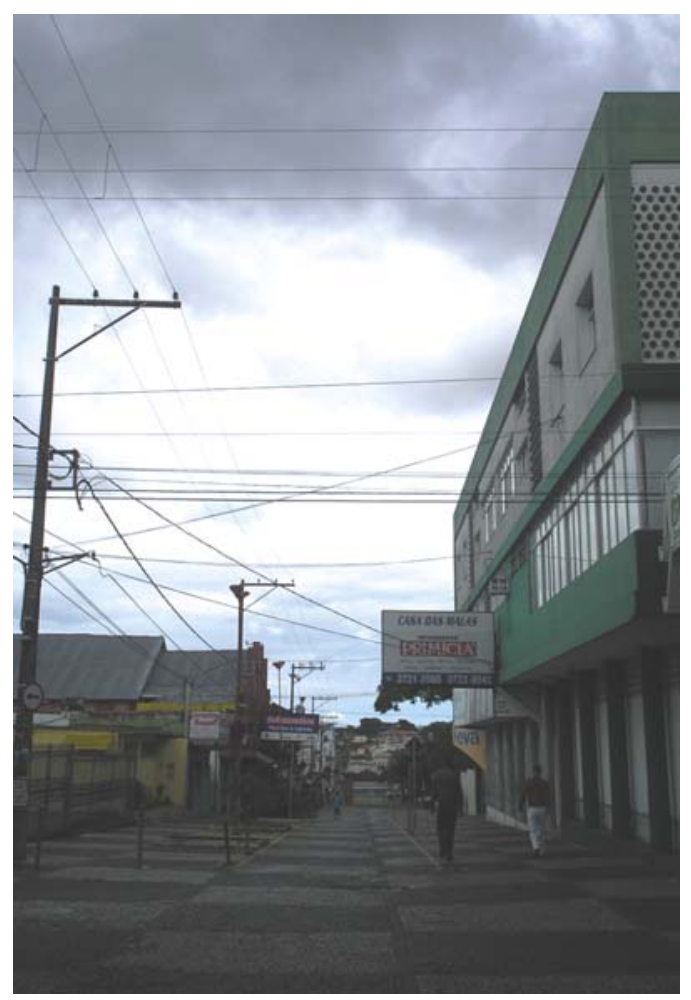

Figura 56. Vista atual da rua Mal. Deodoro, transformada em calçadão no primeiro governo de Ary Balieiro.

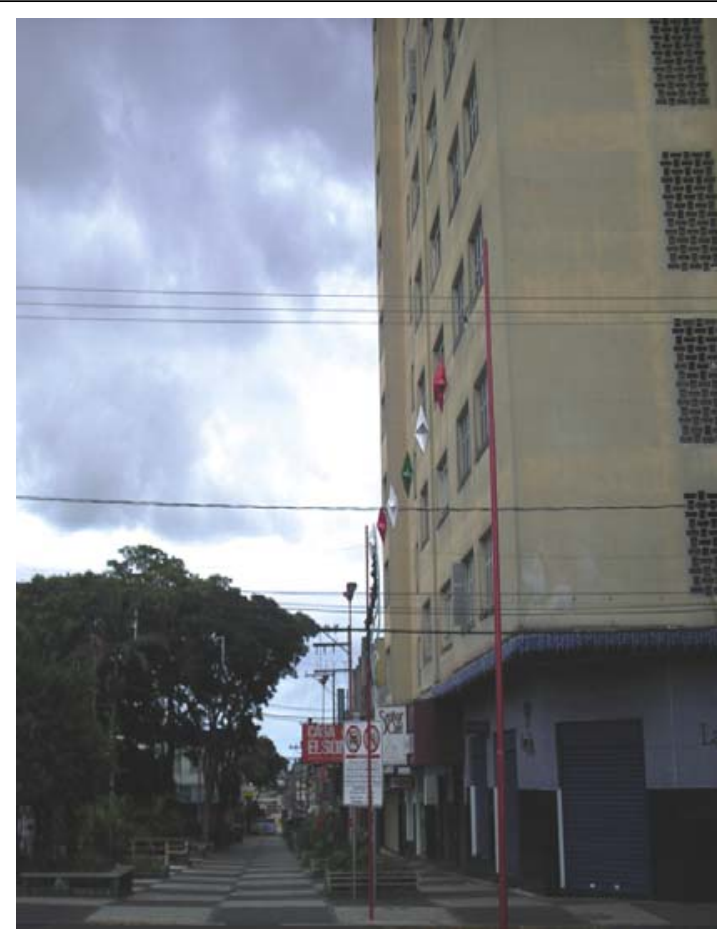

$\pi$
0
0
0
0
0
0
0
0
0
0
0
0
0
0
0
0
0
0
0
0
0
0
0
0
0
0
0

Figura 57. Vista atual da rua Gal. Telles, transformada em calçadão em 1988, no governo de Ary Balieiro.

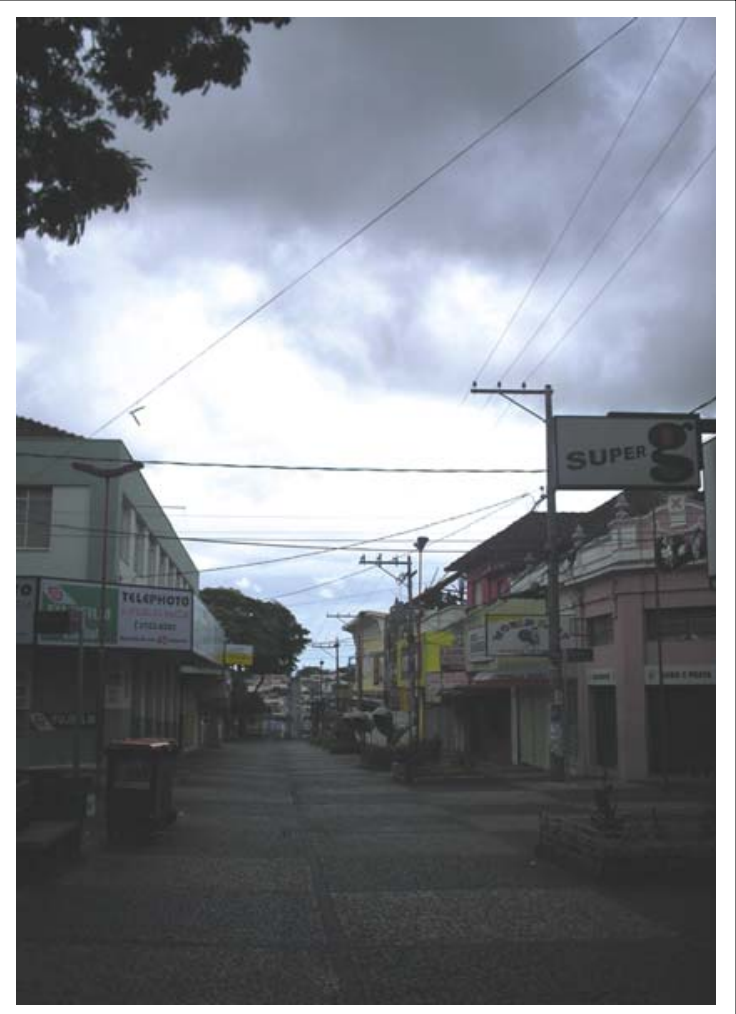

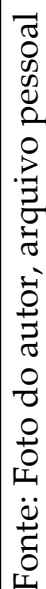

Figura 58. Vista atual da rua do Comércio e praça Barão da Franca, transformadas em calçadão. 
O projeto, atribuído ao arquiteto Antônio Fernando Silva, servidor de carreira da Prefeitura, previu a colocação de um piso de pedras portuguesas em todas as vias, inclusive refazendo o trecho existente da rua do Comércio, iluminação diferenciada e uma ampla reformulação dos jardins na região. A intervenção, à época, recebeu críticas na imprensa, porém foi apoiada e incentivada pela poderosa Associação Comercial e Industrial de Franca - $\mathrm{ACIF}^{20}$. De qualquer modo, o calçadão pouco se diferenciava em termos físicos aos anteriores, imitando Curitiba no tipo de piso, luminárias e jardineiras.

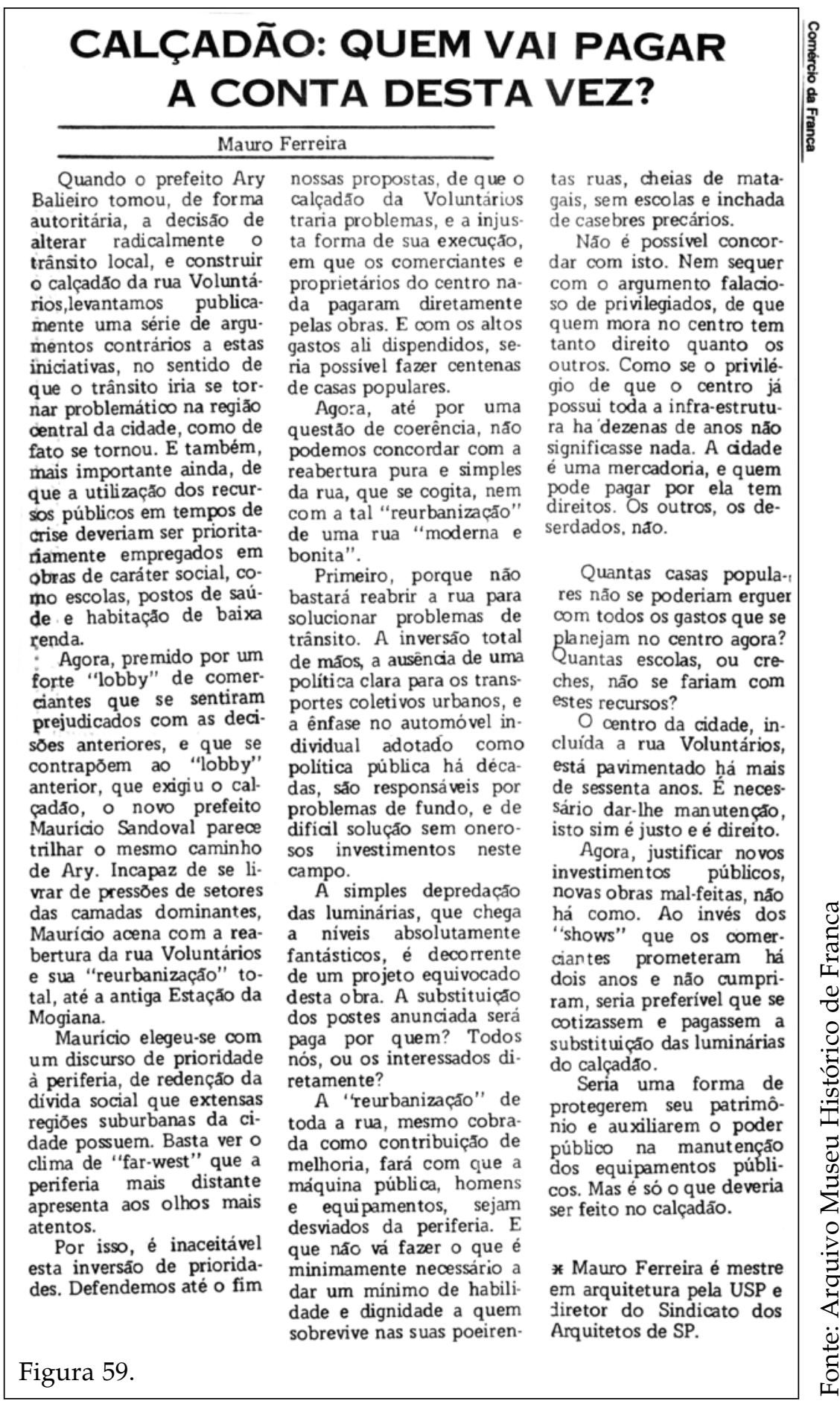

${ }^{20}$ Ver artigos "Calçadão, quem vai pagar a conta desta vez", COMERCIO DA FRANCA, 20 de setembro de 1987, p.2, do autor, e "Contribuição de Melhoria. Quem paga?", COMÉRCIO DA FRANCA, 22 de setembro de 1987, p.2, de autoria de Luciano Botto, presidente da ACIF. 


\section{Contribuição de melhoria. Quem paga?}

$\star$ Luciano C. D. Bôtto

O arquiteto Mauro Ferreira fez publicação domingo último de um artigo, com o título acima, que recebe agora o posicionamento de um lojista francano como eu, que posso até entender seu ponto-de-vista com respeito à lei da "Contribuição de Melhoria", porque também a considero esdrúxula, feita para atender interesses alheios à vontade popular.

Todavia, não entendo por que o Arquiteto se volta contra a classe dos empresários lojistas como se o "calçadão" que se implantará num trecho da rua Voluntários da Franca e outras próximas, fosse exigência ou fruto de negociação com o Poder Executivo. Nada disso...

Os "calcadões" no centro comercial são an-

Figura 60. paga pelos empresários lojistas. Primeiramente porque cerca de $70 \%$ dos imóveis não pertencem aos lojistas, são alugados e, segundo, o "calçadão" não virá por certo valorizar os imóveis, muito pelo contrário: a maioria enfrentará, com isso, inúmeros problemas. Só que, todos entendem sua viabilidade como fruto do progresso e da tranqüilidade que trará à cidade como um "todo", o que nós lojistas e nem o Arquiteto conseguiremos deter.

Temos convicção de que os "calçadões" de Franca darão certo, como aliás ocorre em outras grandes e médias cidades brasileiras, além do sucesso que fazem há décadas na Europa, que dão a essas áreas um tratamento humanizado, valorizando o transeunte em detrimento de veiculos poluidores do meio-ambiente.

As críticas ao fato de não ser cobrada contribuição de melhorias dos proprietários dos imóveis centrais para realização das obras foram substituídas, mais adiante, pelas críticas à decadência comercial da rua Voluntários da Franca, cujo fechamento no trecho do calçadão e estabelecimento de novas rotas para o transporte coletivo constituíram fatores preponderantes para o impacto observado, no fechamento de estabelecimentos comerciais naquela que tinha sido, durante quase um século, a mais importante via comercial da cidade, pois ligava a antiga estação ferroviária ao centro da cidade.

Embora a proposta original não tenha sido integralmente realizada, principalmente a construção da avenida de contorno do centro, a pedestrianização do centro ocorreu em significativo trecho do comércio da região. Vale lembrar que, a partir dos anos 1970, há um processo de valorização da memória, da organização da sociedade em defesa do patrimônio histórico e do discurso que os cascos históricos centrais das cidades eram elementos geradores de identidade local e essenciais à vida urbana (VARGAS e CASTILHO, 2006).

Este processo de valorização da memória, ao lado da redução de recursos dos municípios durante o período do regime militar para suas atividades, decorrentes da centralização política, eliminaram qualquer possibilidade de apoio político a intervenções radicais e demolidoras como a proposta da avenida de contorno. Mas o processo de implantação dos calçadões deixa marcas da articulação do setor organizado do comércio da região central, como parte diretamente interessada e com poder de pressão sobre o poder público municipal, na defesa dos seus interesses. 


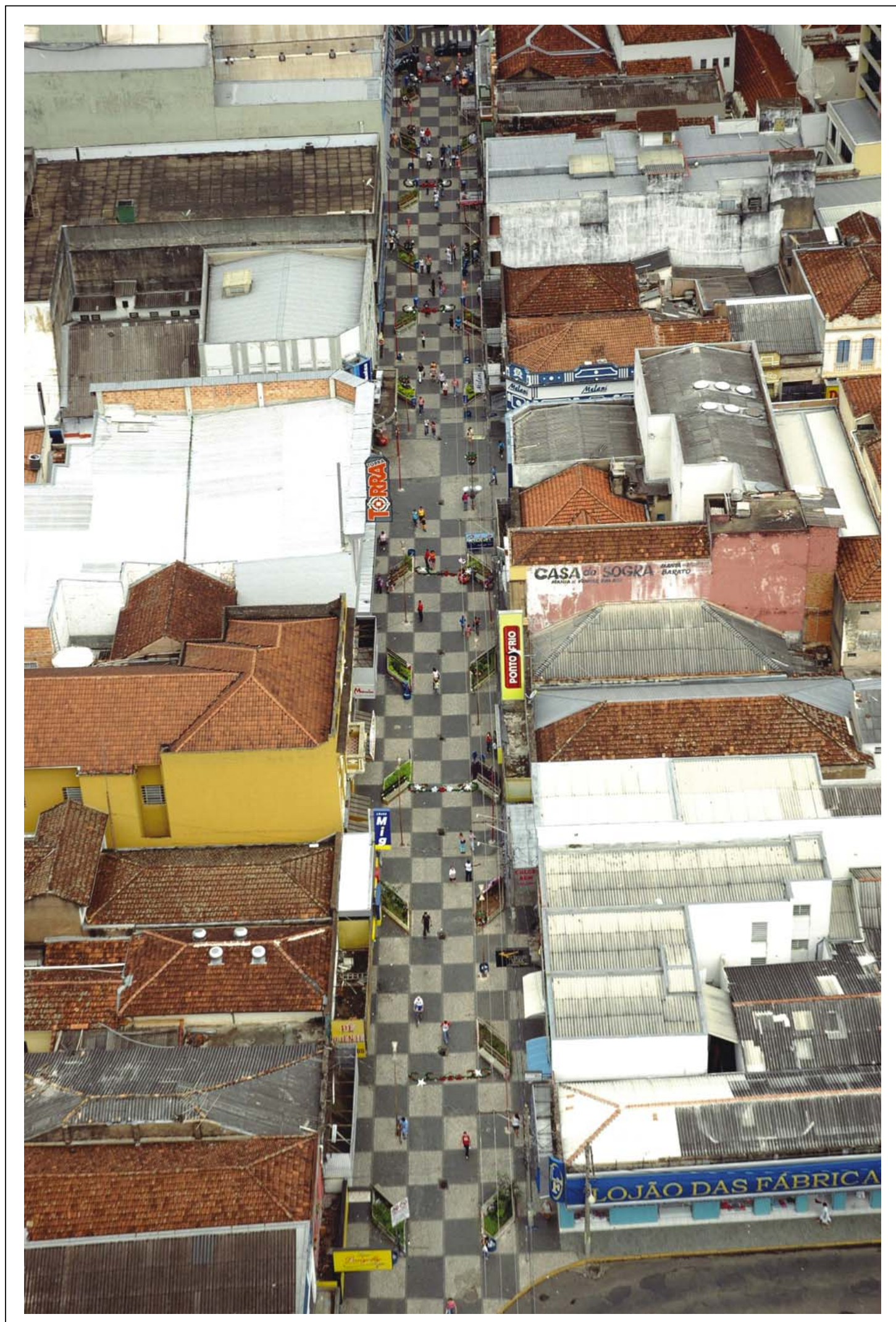

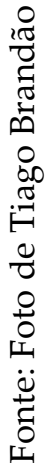

Figura 61. Vista atual do calçadão da rua do Comércio. 


\section{UM PARQUE NA ÁREA CENTRAL: O VALE DOS BAGRES}

A proposta de implantar um parque urbano na região central da cidade, utilizando o fundo de vale do Córrego dos Bagres está prevista no artigo 225 da lei do Plano Diretor. No entanto, já em 1968, durante o primeiro governo de Hélio Palermo, com o Plano Diretor sendo elaborado pela GPI, a lei municipal n. 1.688, de 9 de dezembro, declarava de utilidade pública terreno, estipulando em seu artigo primeiro, que para "utilização como acesso ao futuro bosque que será formado com o aproveitamento das áreas adjacentes do córrego dos Bagres, com ambas as suas margens no trecho compreendido que vai da rua Voluntários da Franca até a rua Simão Caleiro", com uma área total de $6.518 \mathrm{~m}^{2}$. O prefeito Hélio Palermo também tentou obter recursos junto ao governo federal para a execução das obras, pois em seu noticiário de 16 de fevereiro de 1968, o jornal Comércio da Franca informava que Hélio Palermo havia obtido recursos do Departamento Nacional de Obras contra a Seca - DNOS para fazer um lago no córrego dos Bagres, que poderia ser utilizado para o lazer da população. No entanto, os recursos que vieram do convênio com DNOS foram suficientes apenas para canalizar um pequeno trecho do córrego dos Bagres, do encontro das águas do Bagres com o córrego Espraiado até a rua Cuba, no Jardim Consolação, já no governo Lancha Filho.

Posteriormente, em 1970, também no governo Lancha Filho, a lei n. 1955, de 15 de dezembro de 1970 autorizou o Executivo a expropriar, por via amigável, um conjunto de imóveis, com o objetivo de possibilitar a abertura e retificação de ruas e construção de locais de recreio junto ao futuro vale dos Bagres. Nos termos desta lei, foram três os imóveis a serem desapropriados, totalizando um acréscimo de $6.197 \mathrm{~m}^{2}$ de terrenos,

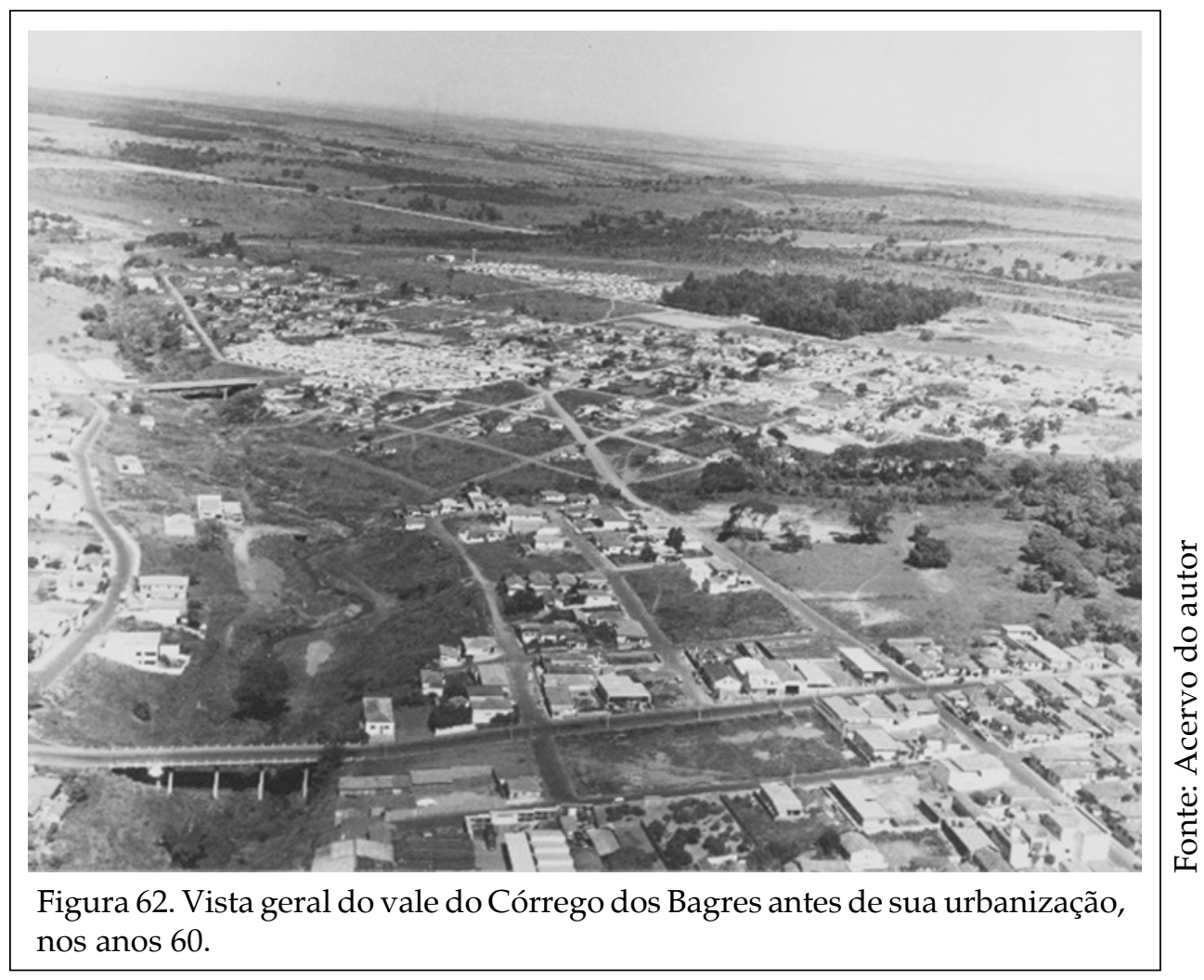




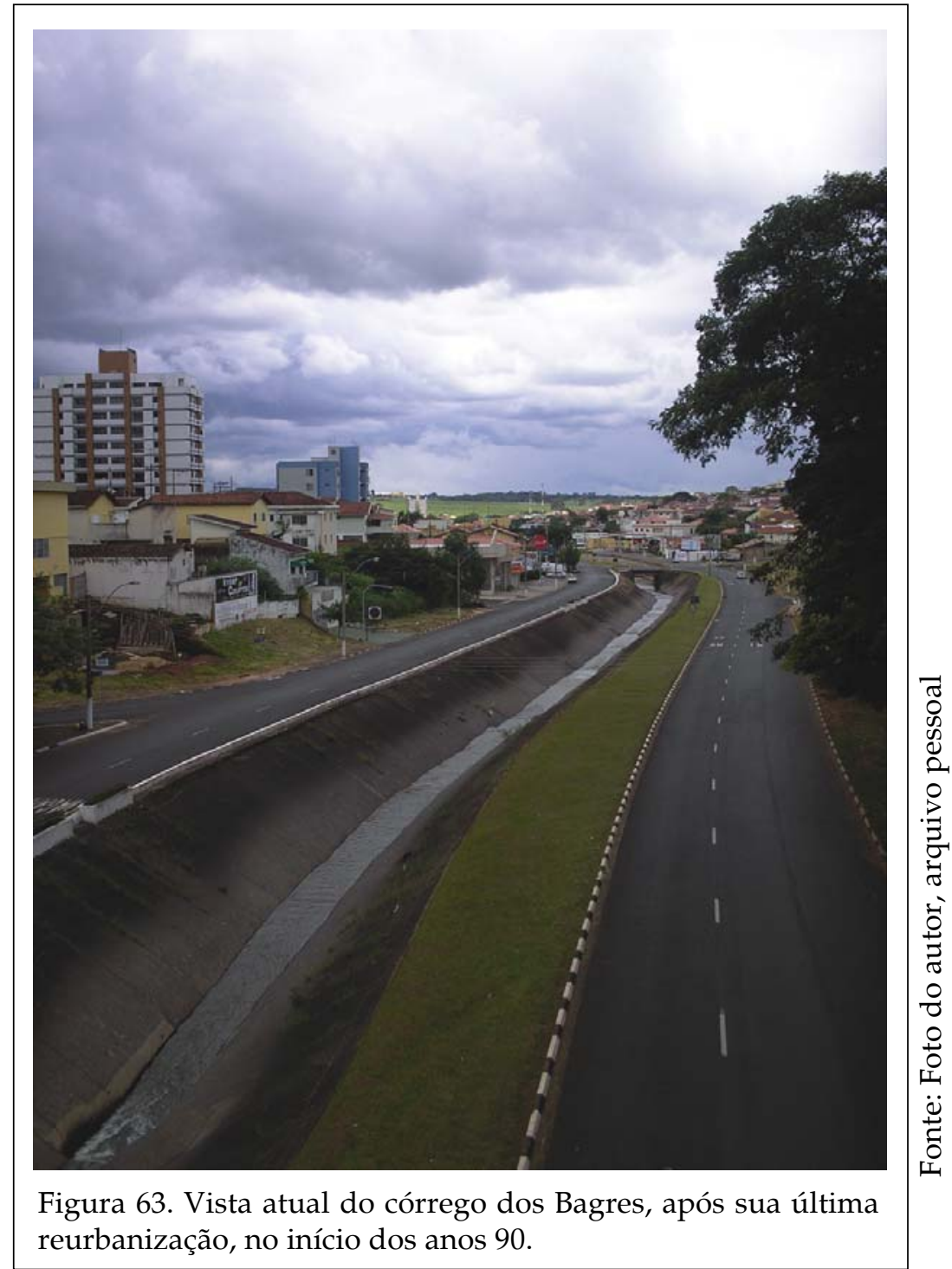

todos lindeiros ao córrego dos Bagres, anexos àqueles previstos anteriormente pela lei $1.688 / 68$.

É mais uma evidência que o Plano, desde o princípio, incorporou diretrizes de governo e demandas locais no âmbito do processo de elaboração do Plano Diretor. Lancha Filho deu conseqüência à proposta, elaborando um projeto de urbanização de trecho do fundo de vale do córrego dos Bagres, entre a cachoeira da rua Voluntários da Franca e a rua Comandante Salgado. Os serviços foram iniciados por volta de agosto de 1972, incluindo a canalização de mais um trecho do córrego dos Bagres, a abertura de uma avenida marginal à mesma (avenida Costa e Silva), executada em parte com recursos federais do DNOS ${ }^{21}$.

O projeto do parque, de autoria do arquiteto Luiz do Couto Rosa, previu a canalização do córrego após a queda da cachoeira, cujas águas despencavam sobre uma espécie de dissipador natural de energia em pedras naturais, acessada por um

\footnotetext{
${ }^{21}$ COMERCIO DA FRANCA, 24 de agosto de 1972, p.12
} 
conjunto de escadarias incrustradas na pedra e um pequeno caminho pavimentado para os pedestres. Foram construídos também um anfiteatro ao ar livre, para apresentações teatrais e musicais, um parque infantil, quiosques, passeios e ainda o tratamento paisagístico e a revegetação das encostas do vale.
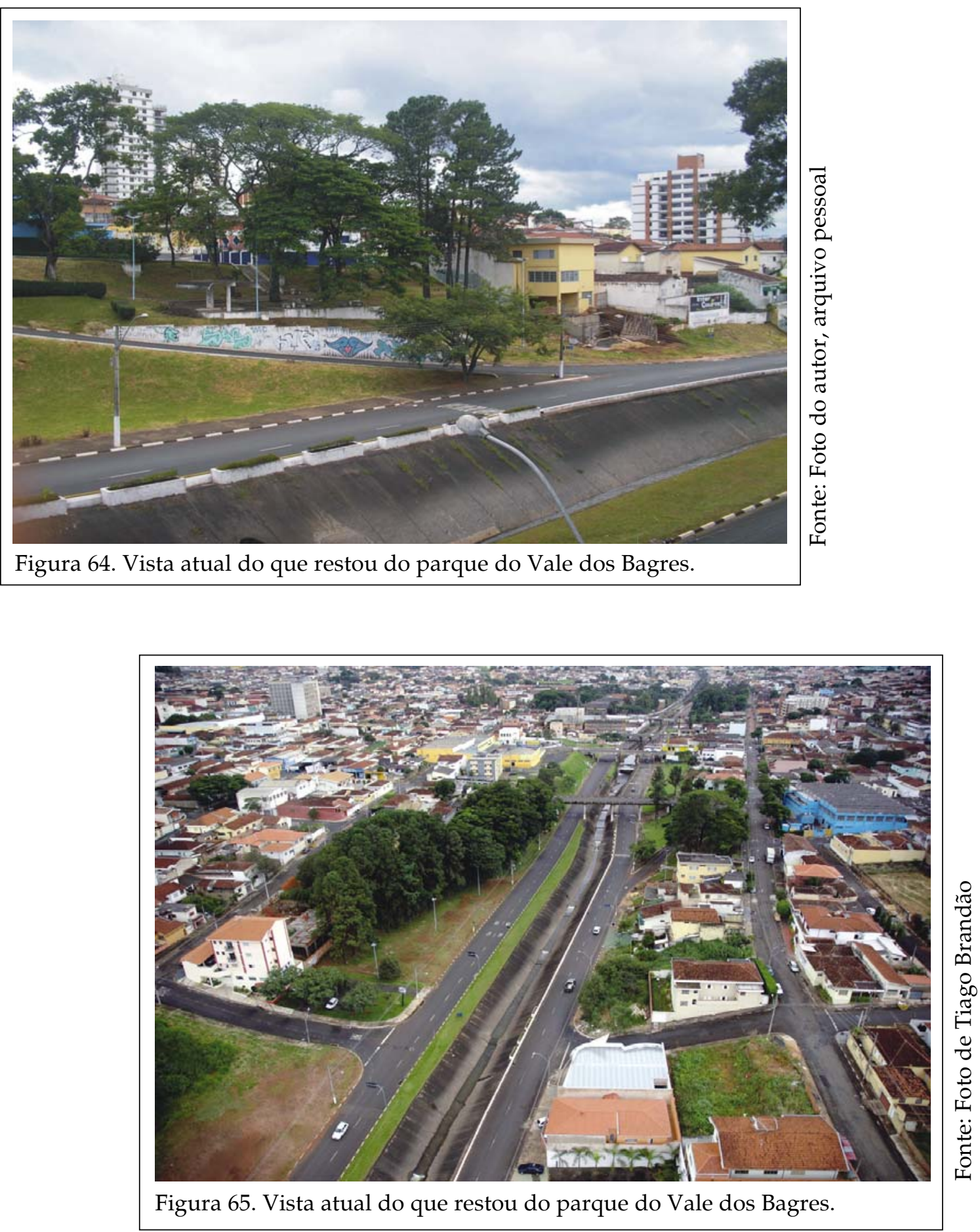
A obra foi inaugurada, mesmo incompleta, em 11 de novembro de 1972, no final do governo Lancha Filho e às vésperas das eleições municipais, vencidas por Hélio Palermo contra o candidato de Lancha Filho. Durante seu governo, Hélio recebeu várias críticas pelo abandono do projeto. Editorial do jornal "Diário da Franca" 22 criticava o fato: "o lago, antes diversão da garotada, foi esgotado", lamentando ainda a falta de continuidade do projeto do parque, da canalização do córrego e da avenida que o margeava.

\section{0 poder público náo se interessa pelas áreas verdes}
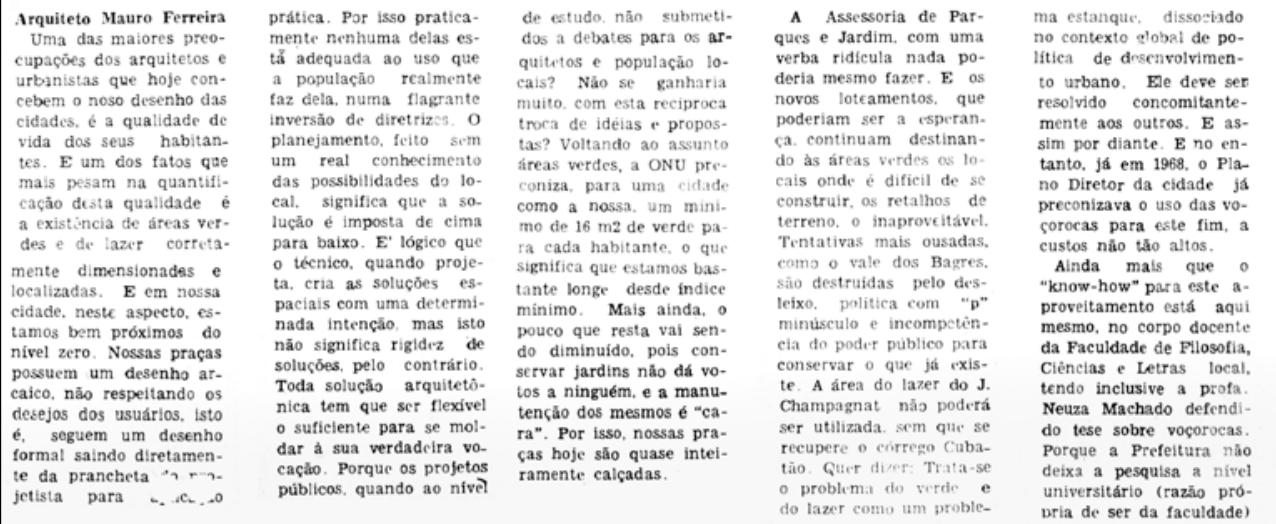

interferir no processo de desenvolvimento urbano? quipe multidisciplinar para tratar do assunto, com arquitetos, engenheiros. logos, etc, tanto mais porque a má ocupação do solo urbano, nas proximidades das voçoro:as, amplia a erosăo e cria graves problemas sociais (vide norte do Paraná) Nato temos parques, nem arase. nem drvoses. de poderemos ficar llvres c em contato com a natureza, onde poderemos deixar nossas crianças soltas? Será que ainda é proibido pisar na grama. pela sua própria inexis-

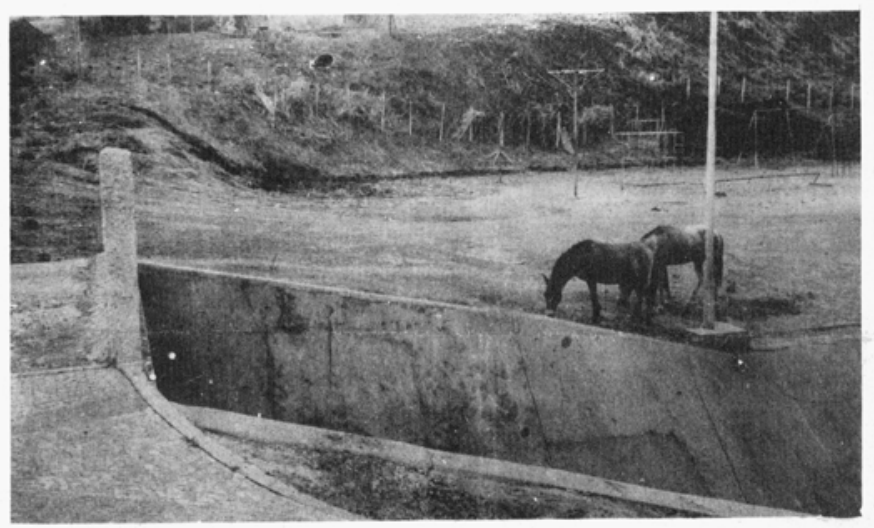

Figura 66. Críticas ao abandono do Vale dos Bagres

${ }^{22}$ DIARIO DA FRANCA, 05 de abril de 1973, p. 2 
Somente no início dos anos 1980, já no governo de Maurício Sandoval Ribeiro ${ }^{23}$, foram recuperadas as instalações principais do parque, sendo construídos novos equipamentos, como uma quadra poli esportiva e um bar, visando revitalizar o local, que havia sido abandonado durante boa parte da segunda gestão de Hélio. No entanto, os problemas de mau-cheiro pelo lançamento de esgotos sem tratamento no córrego dos Bagres, a manutenção inadequada, falhas na limpeza e de vigilância do patrimônio público permaneceram, propiciando sua ocupação por desocupados que geraram insegurança em seus usuários, o que acentuou ainda mais o abandono do local pelo poder público.

Posteriormente, no início de 1988, durante o primeiro governo de Ary Balieiro, foi dado início ao projeto de uma avenida de fundo de vale no local, que destruiu todos os equipamentos de lazer existentes e boa parte da vegetação do parque, seccionandoo em duas partes e eliminando qualquer resquício de um parque urbano, tal como havia sido proposto originalmente, pois foi invadido pelo ruído e pelos automóveis em alta velocidade. À época, o prefeito Ary Balieiro justificou as intervenções que realizaria da seguinte maneira:

o sistema viário de Franca exige a interligação das avenidas Antônio Barbosa Filho à avenida dr. Hélio Palermo e, por isto, há necessidade de uma obra de arte sobre o córrego dos Bagres e sob a rua Voluntários da Franca (...) a implantação de duas pistas envolve o sacrifício de algumas árvores do Vale dos Bagres (...) o crônico Vale dos Bagres, que passa a ser área integrada ao sistema viário e deixará de se reduto de ações excusas (...) e haverá inclusive mais uma opção de acesso às saídas oficiais de Franca ${ }^{24}$.

Com o uso intensivo de explosivos, foi retirada a cachoeira natural existente para em seu lugar colocar um canal com escadaria em concreto, que foi inteiramente destruído por três vezes consecutivas, tal a velocidade e violência das águas, demonstração de um erro primário de engenharia hidráulica e estrutural e de grande desconhecimento e desconsideração ao meio ambiente.

Verifica-se que, embora o projeto original do Parque do Vale dos Bagres tenha sido posteriormente descaracterizado e destruído em boa parte, assim como os fundos de vale do córrego do Bagres não tenham recebido adequado tratamento paisagístico, que um elemento importante das propostas previstas pelo Plano Diretor foi realizado, demonstrando na prática a viabilidade técnica de criar áreas verdes e paisagísticas em locais centrais e de fácil acesso à população.

\footnotetext{
${ }^{23}$ Com projeto de arquitetura elaborado pelo autor.

${ }^{24}$ DIÁRIO DA FRANCA, 14 de novembro de 1987, p.3.
} 


\section{TRANSFORMANDO VOÇOROCAS EM ÁREAS URBANIZADAS}

A proposta do Plano Diretor definiu, em seu artigo 225 da lei, a reserva de um total de 20 áreas de voçorocas e fundos de vale que deveriam ser expropriadas e transformadas em áreas de lazer, como sugeriam os estudos de $\mathrm{Ab}$ 'Saber. Conforme estabelecido no referido artigo, as áreas deveriam ser destinadas à implantação de centros de tempo livre, onde seriam implantados equipamentos culturais, recreativos, como teatros ao ar livre, parques infantis, restaurantes e bares, dentre outras atrações. Embora o prazo para desapropriação e elaboração dos projetos não tenha sido cumprido (a declaração de utilidade pública era de apenas 240 dias a partir da vigência da lei, prazo impraticável para o orçamento municipal), várias destas áreas foram de fato sendo transformadas em áreas de lazer, ao longo dos diversos governos, e outras em equipamentos públicos.

A seguir, podemos verificar qual foi a destinação para cada uma das voçorocas listadas nos estudos de Ab'Saber e inseridas na Lei do Plano Diretor.

\section{- VOÇOROCA DO PARQUE SÃO JORGE}

A voçoroca do Parque São Jorge foi aterrada parcialmente com resíduos sólidos da construção civil, durante toda a década de 1970. No início dos anos 80, com projeto do autor, na parte mais alta do local, que já era pública e não tinha sido aterrada, a Prefeitura construiu uma praça e uma escola infantil. Posteriormente, durante o governo de Sidnei Rocha (1983-1986), o restante da área foi limpo, arborizado e recebeu equipamentos esportivos e de lazer, como campo de futebol.

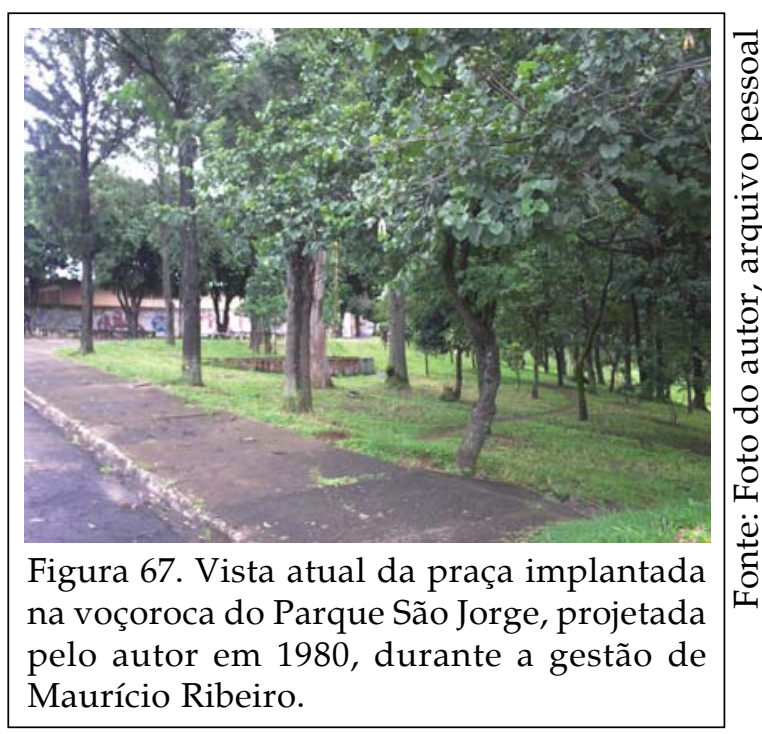

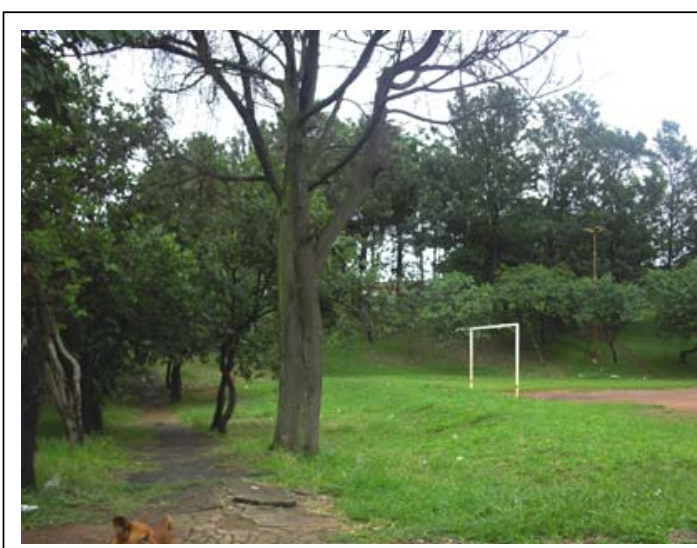

Figura 68. Vista atual da área esportiva, implantada em 1984, na gestão de Sidnei Rocha. 

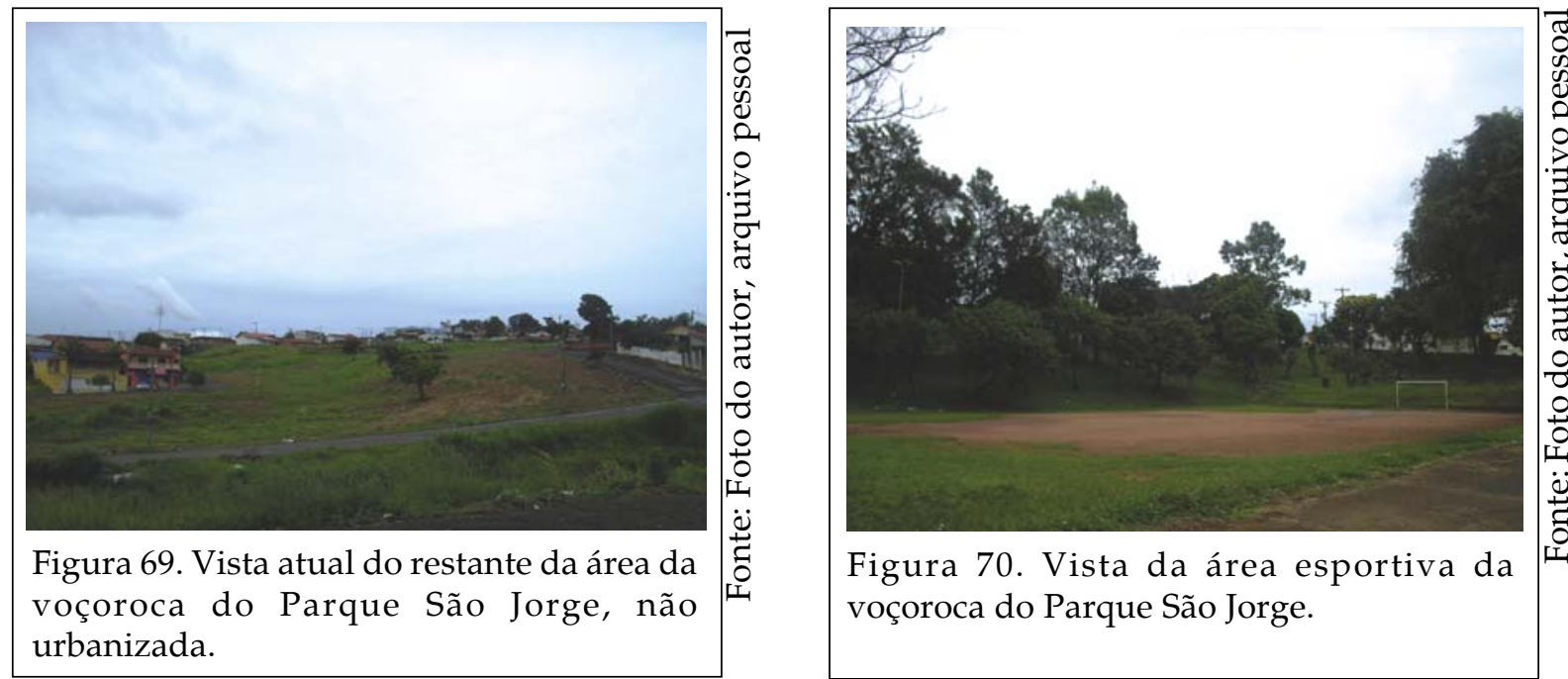

\section{- VOÇOROCA DAS MARITACAS}

A voçoroca das Maritacas era a maior de todas, à época de elaboração do Plano Diretor. Durante parte dos anos 1970 e 1980, recebeu aterro municipal com resíduos domésticos, tendo sido sua área objeto de desapropriação e doação de áreas institucionais por empreendimentos imobiliários anexos. Manifestação dos moradores, contrários ao aterramento, por causa do mau-cheiro e problemas sanitários decorrentes dos serviços, fez com que a Prefeitura elaborasse um projeto de aterro industrial no local, que funcionou de 1988 até 2004, quando foi definitivamente encerrado ${ }^{25}$, prevendo-se finalmente sua transformação num grande parque urbano. No entanto, as áreas mais altas e que não tinham sido aterradas, receberam quadras esportivas e uma escola municipal.

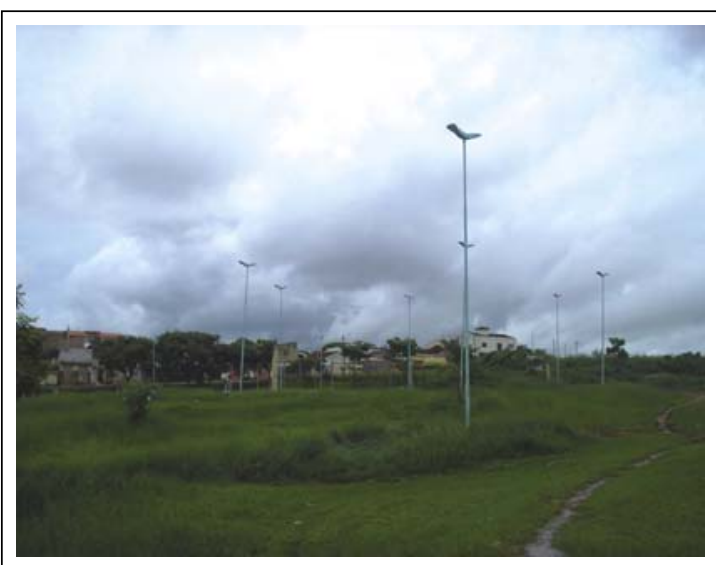

Figura 71. Vista atual de parte urbanizada da voçoroca das Maritacas, construída durante o governo de Ary Balieiro, em 1994.

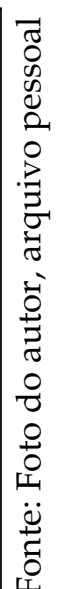

Figura 72. Vista atual de parte já aterrada, porém não urbanizada da voçoroca das Maritacas.

\footnotetext{
${ }^{25}$ O Termo de Encerramento do Aterro Industrial assinado entre Prefeitura e Cetesb em 2004 prevê, além do monitoramento das águas, a recuperação e arborização de toda a área aterrada. Também o novo Plano Diretor da cidade, aprovado em 2003, prevê sua transformação em parque urbano.
} 


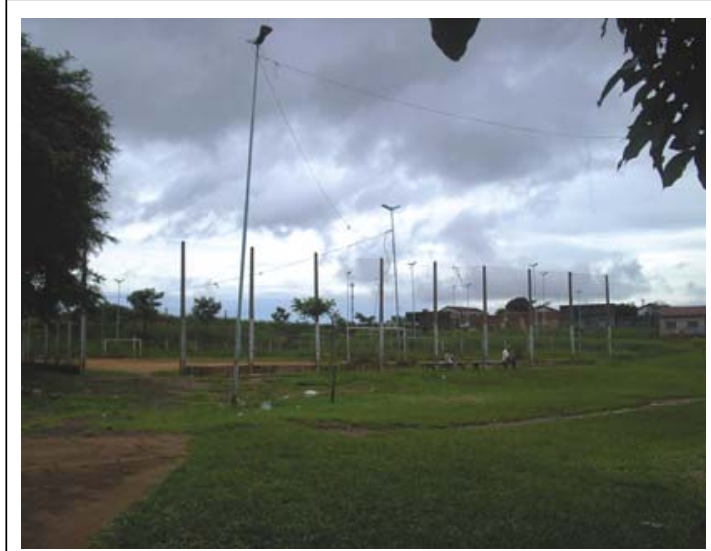

Figura 73. Vista atual de área esportiva implantada na voçoroca das Maritacas, construída no governo de Ary Balieiro, em 1994.

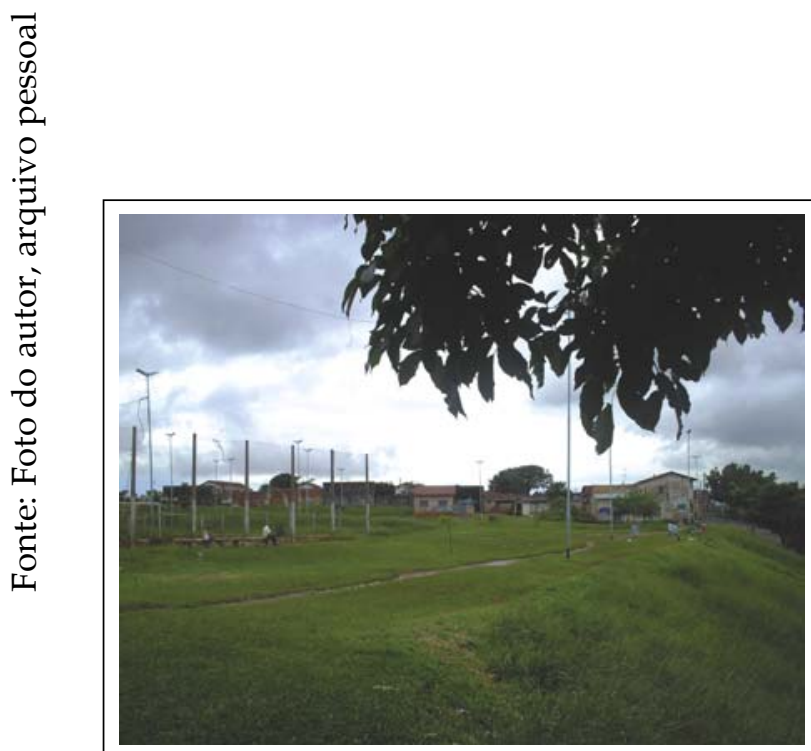

Figura 74. Vista atual da área esportiva da voçoroca das Maritacas.

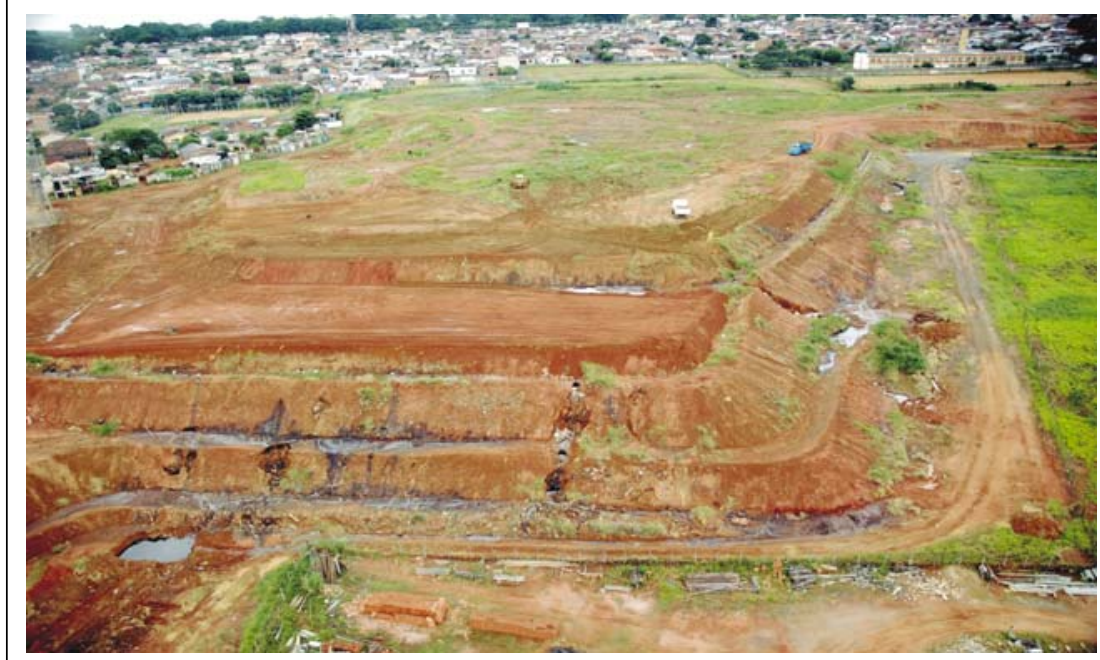

Figura 75. Vista atual do aterro sanitário industrial das Maritacas, após seu encerramento.

\section{- VOÇOROCA DA VILA CATOCOS}

A voçoroca da Vila Catocos foi aterrada paulatinamente durante os anos 1970, sendo parte dela transformada no prolongamento da rua Afonso Pena e parte em áreas ajardinadas e praças. 
- VOÇOROCA DA VILA MONTEIRO

A voçoroca da Vila Monteiro foi, em sua maior parte, urbanizada entre 1987-88, e transformada numa praça pública. Uma pequena parcela foi aterrada e comercializada em lotes por particulares.
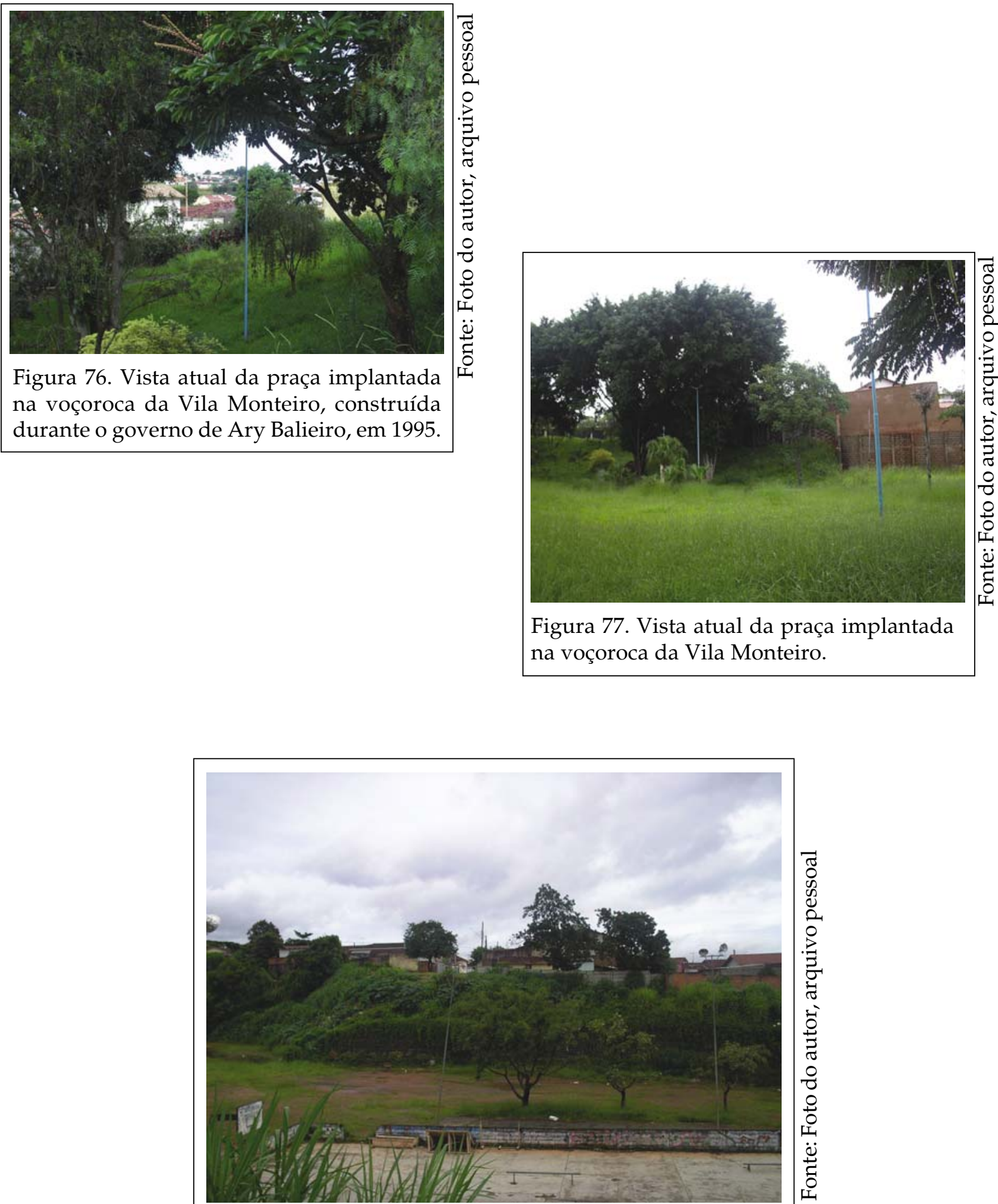

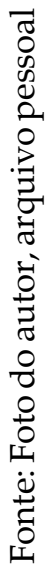

Figura 78. Vista atual da voçoroca da Boa Vista, com equipamentos esportivos deteriorados. 


\section{- VOÇOROCA DA BOA VISTA}

A voçoroca da Boa Vista foi objeto de uma grande intervenção no final dos anos 1970, quando ali foi implantado o Centro Social Urbano - CSU, com recursos obtidos em convênio com a União. Sua área foi parte desapropriada pelo governo municipal e parte obtida através da cessão de áreas exigidas por lei de loteamentos particulares. Porém, suas encostas não foram tratadas, e parte da infra-estrutura de lazer do local foi destruída por deslizamentos, que até hoje ainda colocam em risco moradias particulares situadas em suas bordas.
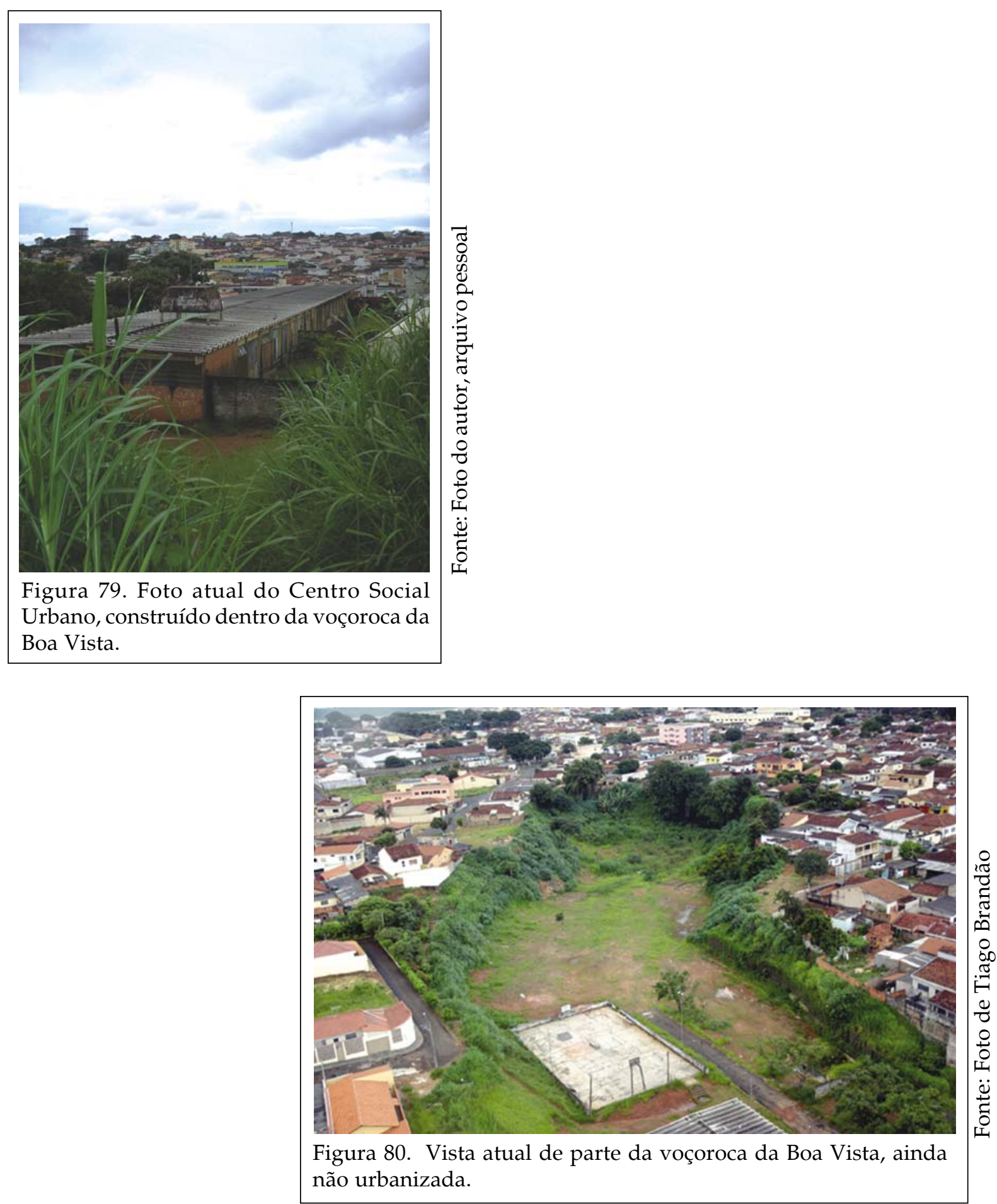
- VOÇOROCA DO PESTALOZZI

A voçoroca do Pestalozzi foi aterrada com resíduos sólidos da construção civil durante a década de 1970, após o desenvolvimento de um projeto de avenida sobre o local, ainda no governo Maurício Sandoval Ribeiro. A partir de 1983, foi urbanizada com a implantação do prolongamento da avenida Major Nicácio, entre a rua Major Claudiano e a avenida Hélio Palermo, marginal ao córrego dos Bagres. A conclusão se deu por volta de 1987, durante o governo de Sidnei Rocha e Ary Balieiro.

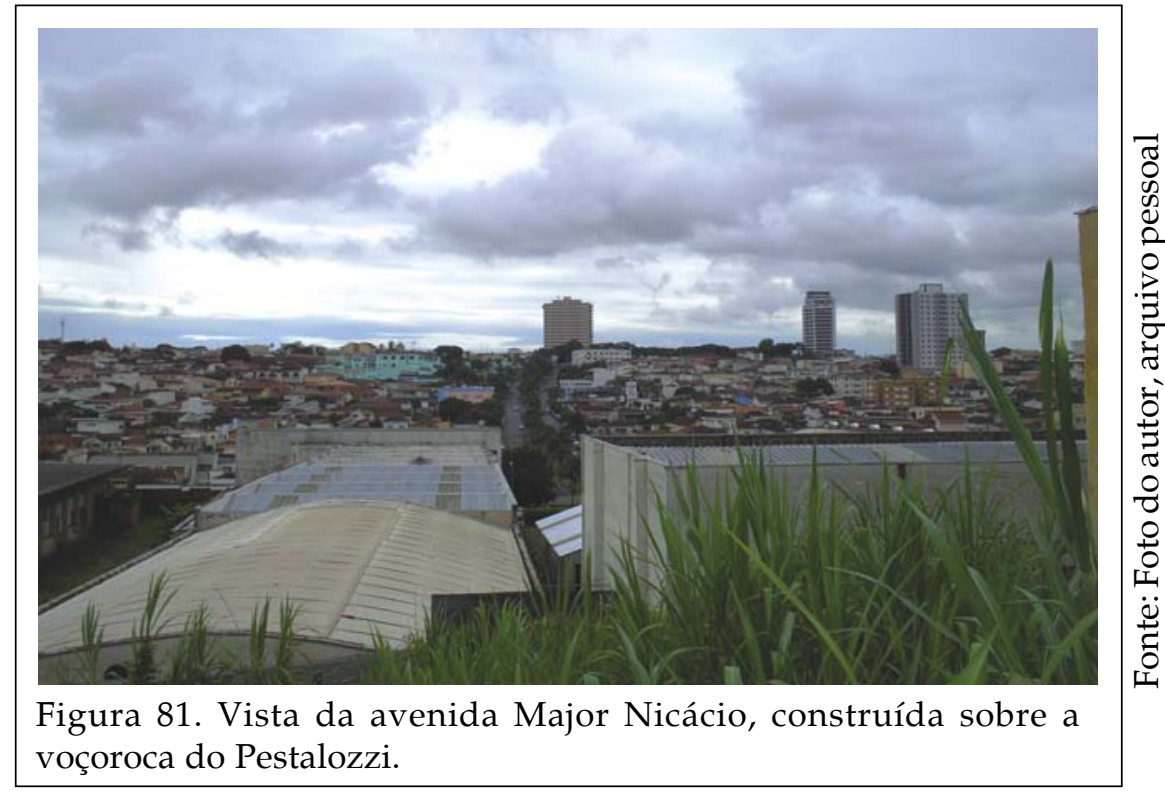

\section{VOÇOROCA DO JARDIM CONCEIÇÃO LEITE}

A voçoroca do Jardim Conceição Leite também foi aterrada com resíduos sólidos da construção civil. Atualmente, parte dela transformou-se na avenida Gini Rocha e parte foi cedida à Prefeitura para implantar área de lazer, não executada ainda.

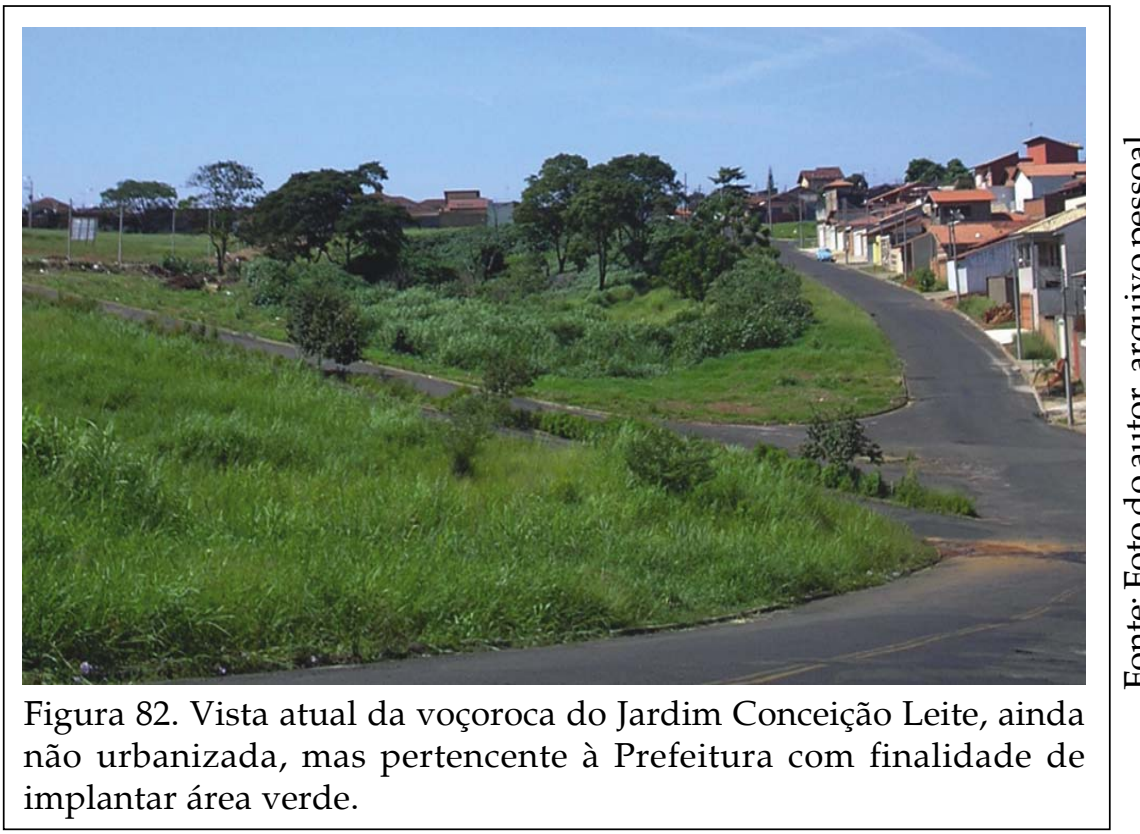




\section{- VOÇOROCA DA VILA RAYCOS}

A voçoroca da Vila Raycos foi parcialmente aterrada com resíduos sólidos da construção civil, porém até hoje é área particular. O novo Plano Diretor da cidade prevê instalação de parque urbano no local.

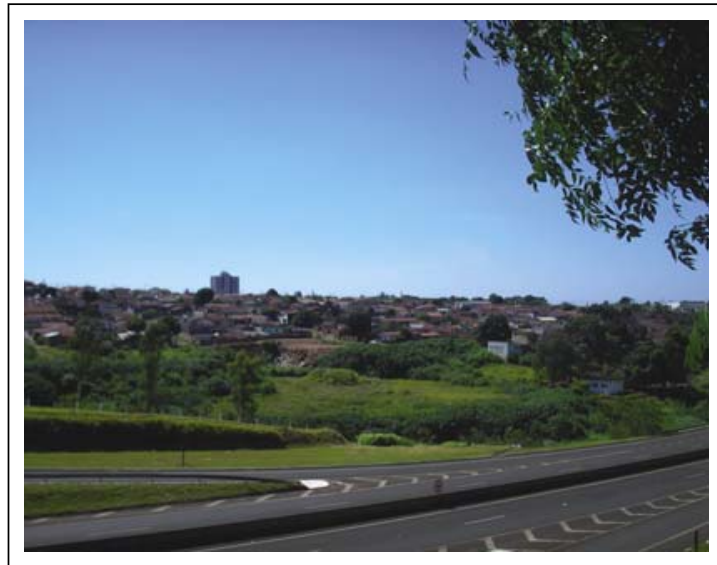

Figura 83. Vista atual da voçoroca da Vila Raycos, que está sendo aterrada com resíduos da construção civil.

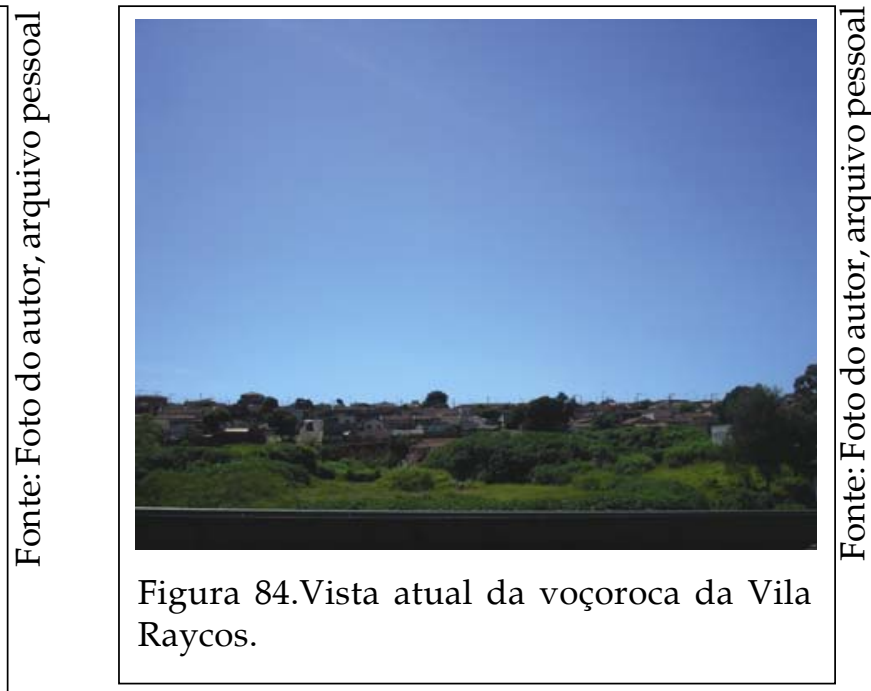

Figura 84.Vista atual da voçoroca da Vila Raycos

\section{- VOÇOROCA DA PONTE PRETA}

Foi urbanizada na década de 1980, parte foi transformada em lotes particulares e comercializada. $\mathrm{O}$ restante foi transformado em área de lazer e praças. A última intervenção efetuada pela Prefeitura foi em 2003, mas ainda há parte significativa da área a ser tratada paisagisticamente.

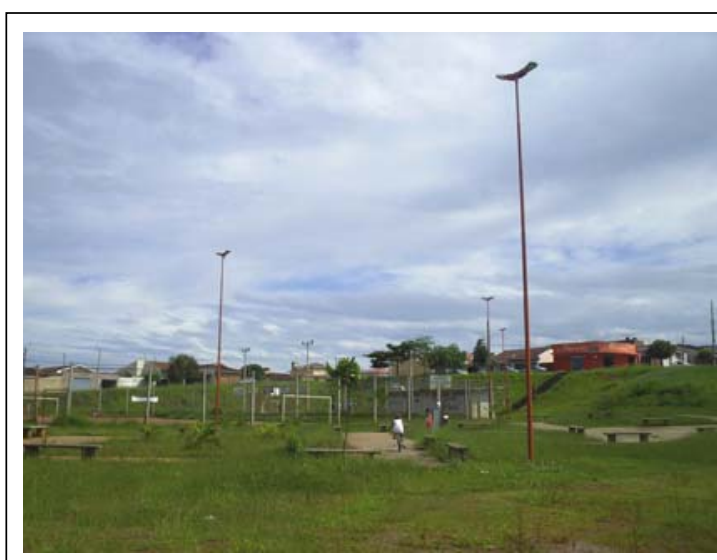

Figura 85. Vista atual de equipamento esportivo implantado na voçoroca da Ponte Preta, durante o governo de Gilmar Dominici (2003).

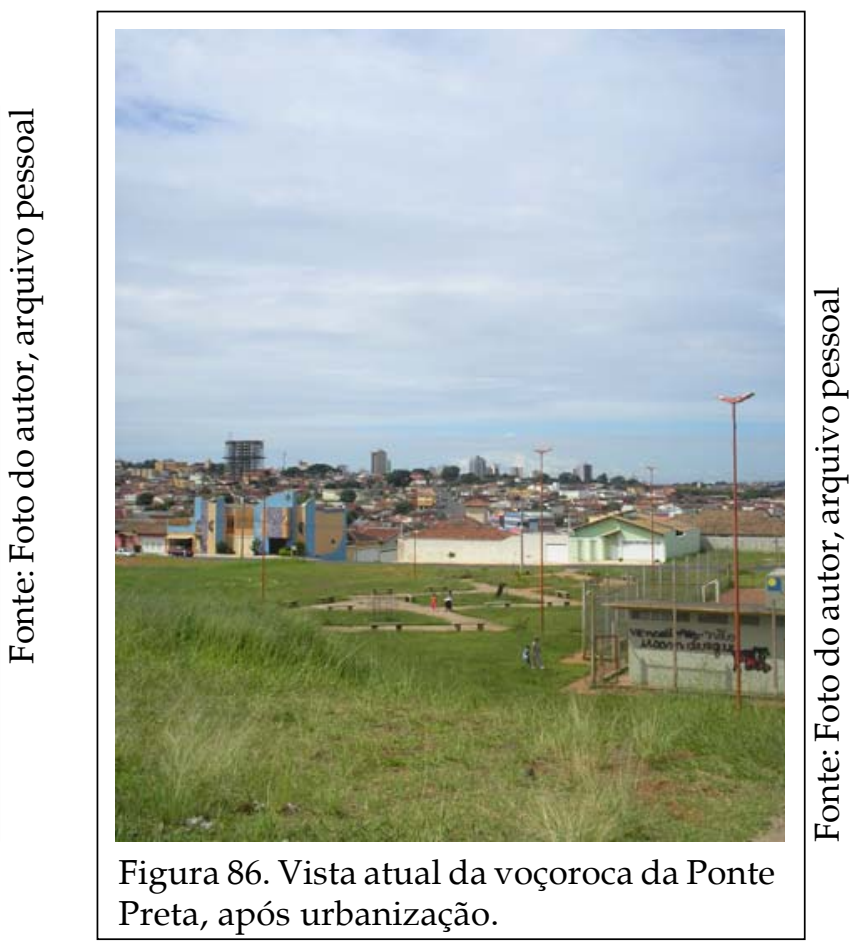


- VOÇOROCA DA VILA PLANALTO

A voçoroca da Vila Planalto foi aterrada e comercializada em lotes por particulares.

\section{- VOÇOROCA DA VILA SAMELO}

Foi urbanizada na década de 1980, transformada em loteamento particular e comercializada em lotes.

\section{- VOÇOROCA VILA PALMEIRAS}

A denominada voçoroca da Vila Palmeiras (na verdade, o Plano deu-lhe esta denominação referindo-se ao campo do Palmeiras Futebol Clube, que fica nas suas imediações), foi aterrada no início de 1981, para ali instalar-se a nova estação rodoviária de passageiros da cidade, com grandes áreas verdes em seu entorno.

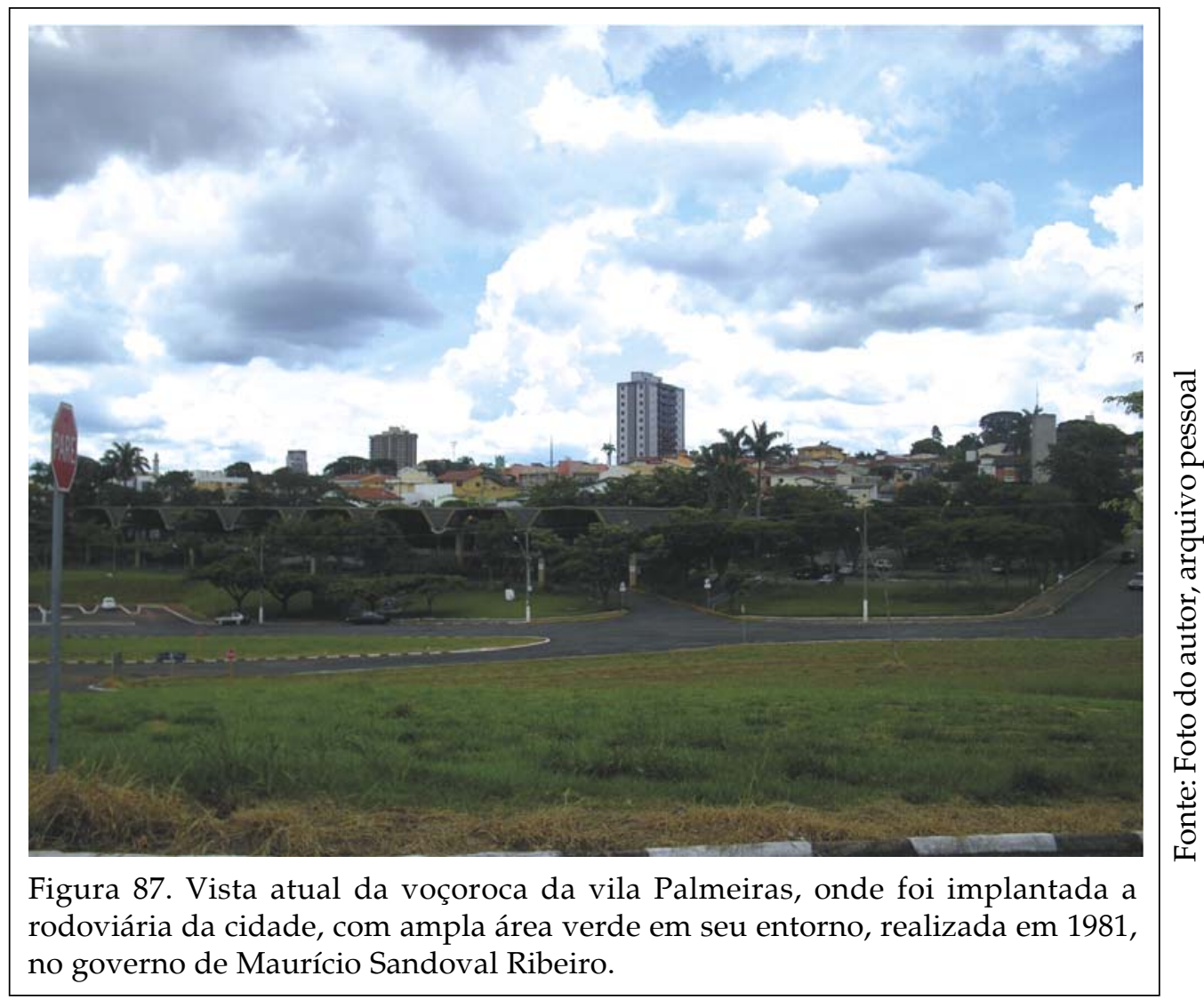




\section{- VOÇOROCA DA MANOEL VALIM}

A voçoroca da Manoel Valim foi urbanizada pela Prefeitura durante o governo de Lancha Filho (1969-1973), que ali instalou a escola municipal Antônio Sichierolli, que funciona até hoje.

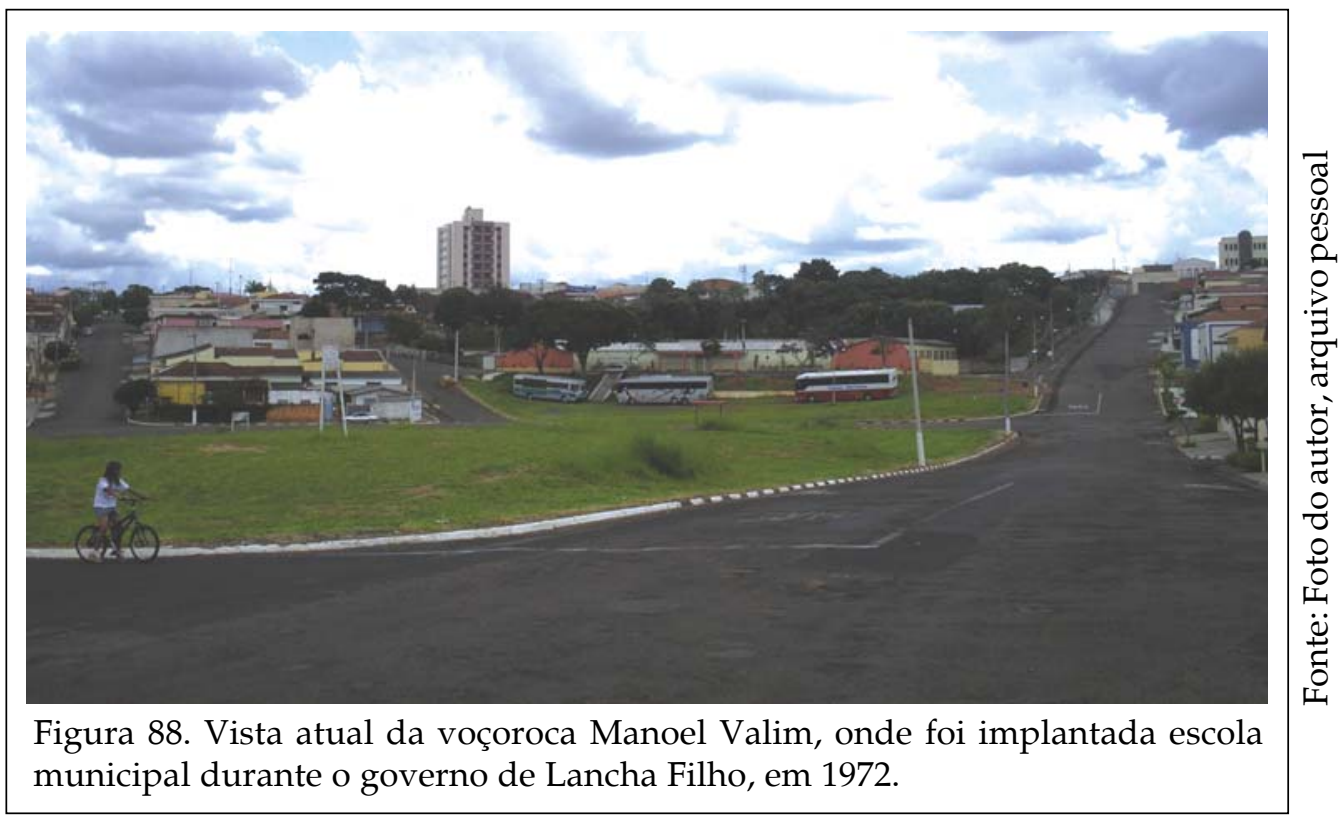

\section{- VOÇOROCA DA SCARABUCCI}

A voçoroca da Scarabucci foi totalmente aterrada e urbanizada por particulares em meados da década de 1970, que transformaram a gleba em lotes comercializáveis, hoje bastante ocupada com edificações. Apenas um pequeno trecho, na parte mais alta, foi reservada à prefeitura. No local, estava prevista a instalação da nova estação rodoviária, que após estudos desenvolvidos pelo governo estadual, foi transferida para a área da voçoroca da Vila Palmeiras.

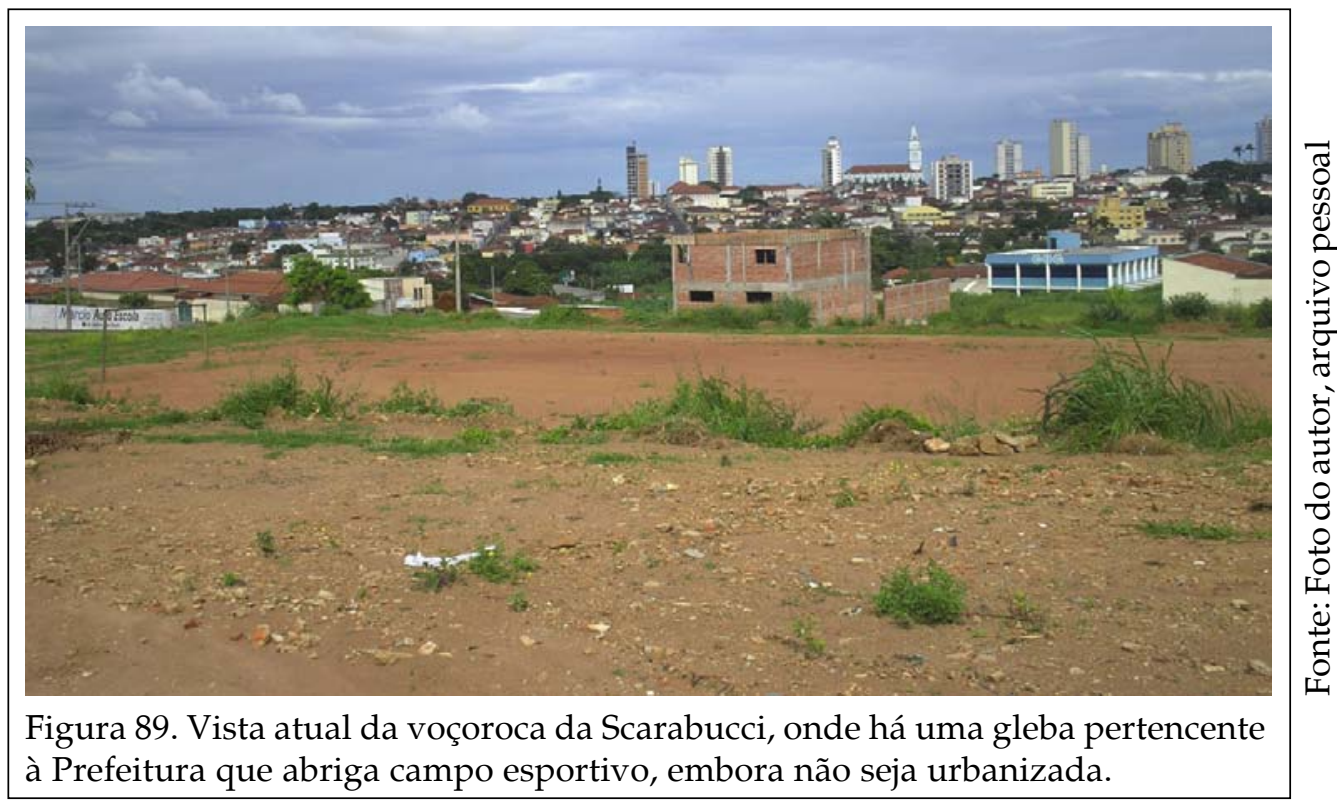


- VOÇOROCA DO QUIRINO

A voçoroca do Quirino também foi totalmente aterrada e drenada por particulares e pela Prefeitura em meados da década de 1970, dando-lhe destinação de lotes residenciais. No local, restaram algumas áreas públicas, mas boa parte delas foi utilizada em permutas para pagamento de desapropriações efetuadas pela municipalidade, principalmente no final da década de 1980. Restou apenas uma praça, denominada Maria Helena Teixeira, localizada na alameda Arminda Nogueira. Foi inaugurada em janeiro de 1983, no final do primeiro governo de Maurício S. Ribeiro, com projeto básico do autor.

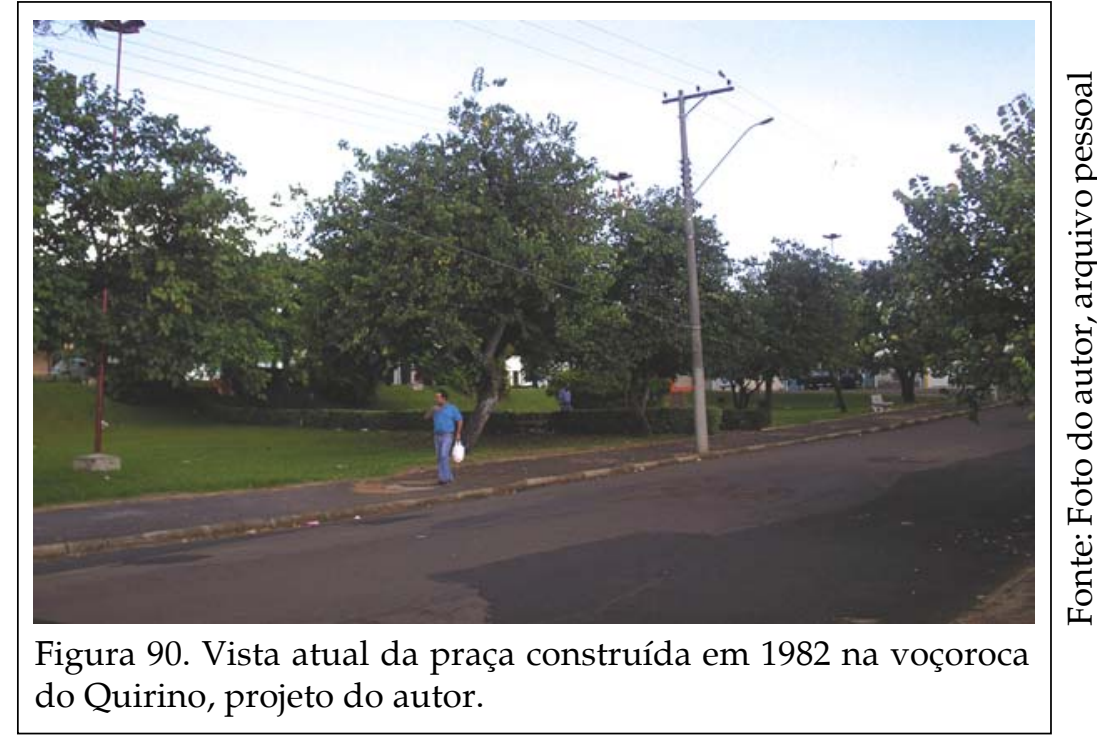

\section{- VOÇOROCA DO CHINÉ}

A voçoroca do Chiné foi, em sua maior parte, aterrada e vendida por particulares na forma de lotes. Existe ainda uma parcela da área desocupada, embora já aterrada. A parcela remanescente foi utilizada como equipamento de lazer da Prefeitura, construído no final dos anos 80, durante o governo Ary Balieiro.

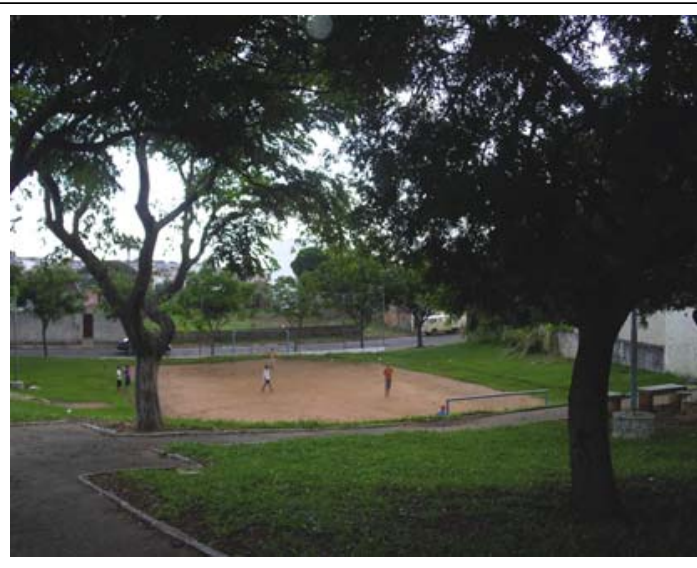

Figura 91. Vista atual da area esportiva implantada na voçoroca do Chiné, construída durante o governo de Ary Balieiro, em 1988.

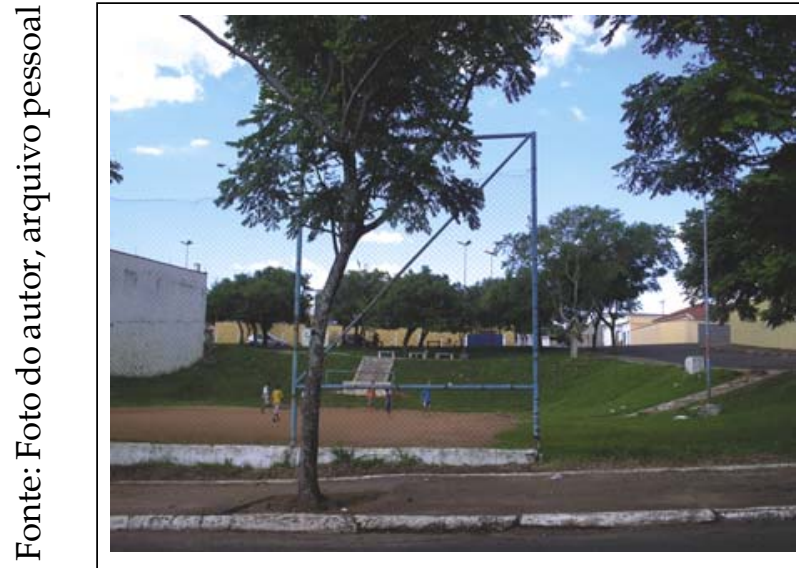

Figura 92. Vista da atual área de lazer da voçoroca do Chiné. 


\section{- VOÇOROCA DE HIGIENÓPOLIS}

A voçoroca de Higienópolis foi transformada em área de lazer e parte num bosque, denominado Jácomo Filetto, durante o governo de Ary Balieiro (1993-1996).
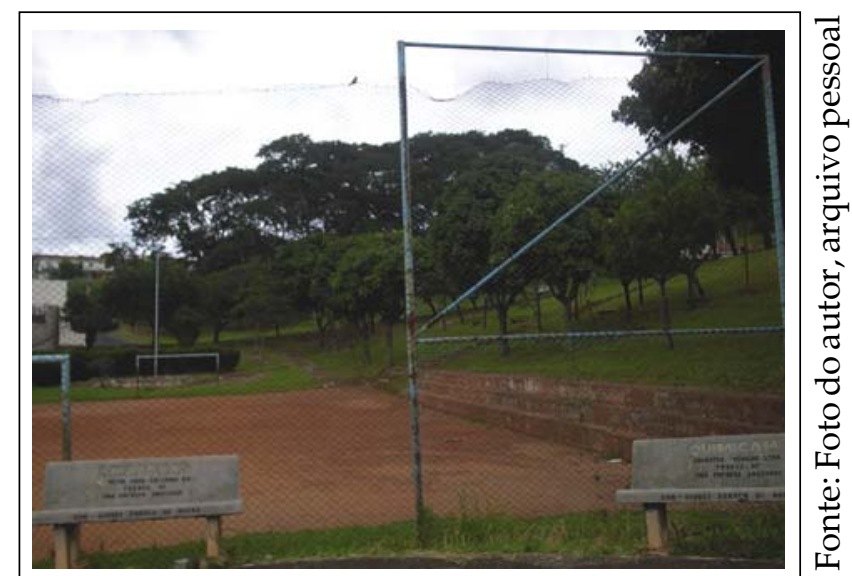

Figura 93. Vista atual da voçoroca de Higienópolis, onde foi implantado equipamento desportivo, durante o governo de Ary Balieiro, em 1988.

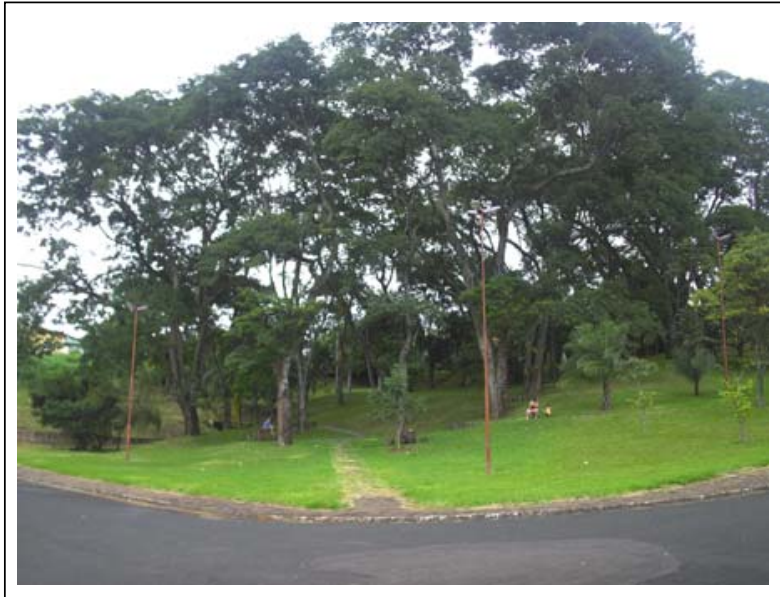

Figura 94. Vista atual da voçoroca de Higienópolis, após implantação de praça, durante o segundo governo de Ary Balieiro, em 1994.

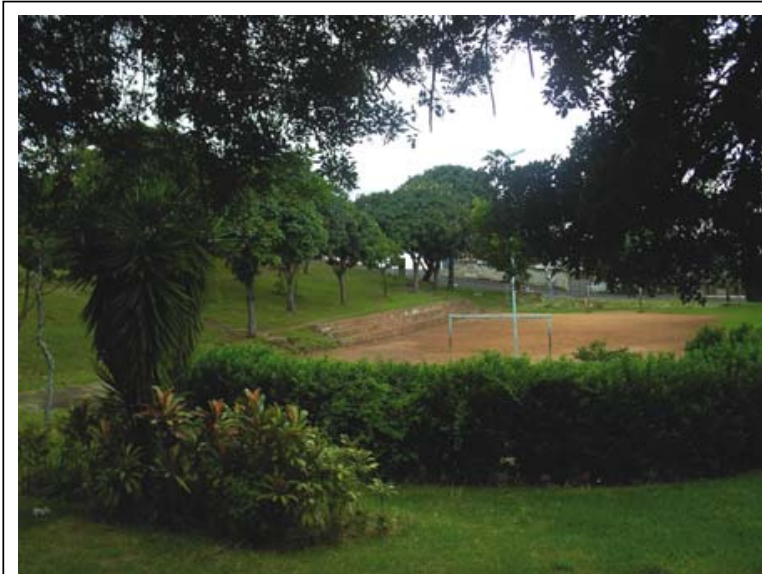

Figura 95. Vista atual de equipamento desportivo na voçoroca de Higienópolis. 
- VOÇOROCA DE ADALGISIO LEITE

A voçoroca de Adalgisio Leite foi aterrada e cedida à Prefeitura por empreendimento particular de loteamento como área destinada à implantação de praça pública no final da década de 1970, porém até hoje a gleba continua sem qualquer tratamento paisagístico.

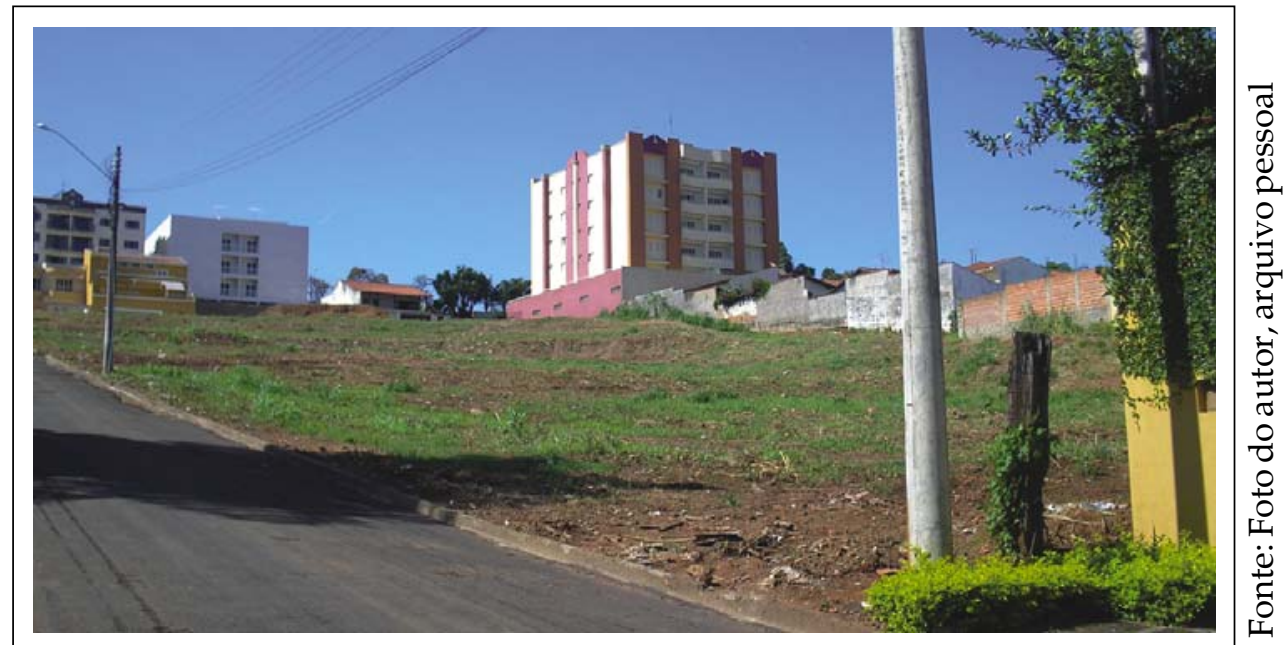

Figura 96. Vista atual da voçoroca Adalgisio Leite, que foi aterrada, embora ainda não urbanizada, pertencente à Prefeitura.

\section{- FUNDO DE VALE DO CÓRREGO DOS BAGRES}

Excetuado o chamado Vale dos Bagres, onde estava previsto o lago e foi implantado um parque público, toda a região prevista para receber tratamento paisagístico foi substituída pela canalização do córrego e implantação das avenidas marginais ao córrego dos Bagres (avenida Antônio Barbosa Filho) e ao córrego do Cubatão (avenida Ismael Alonso y Alonso). Ao longo da canalização, apenas pequenos trechos mantiveram afastamento do curso d'água, com alguma arborização.

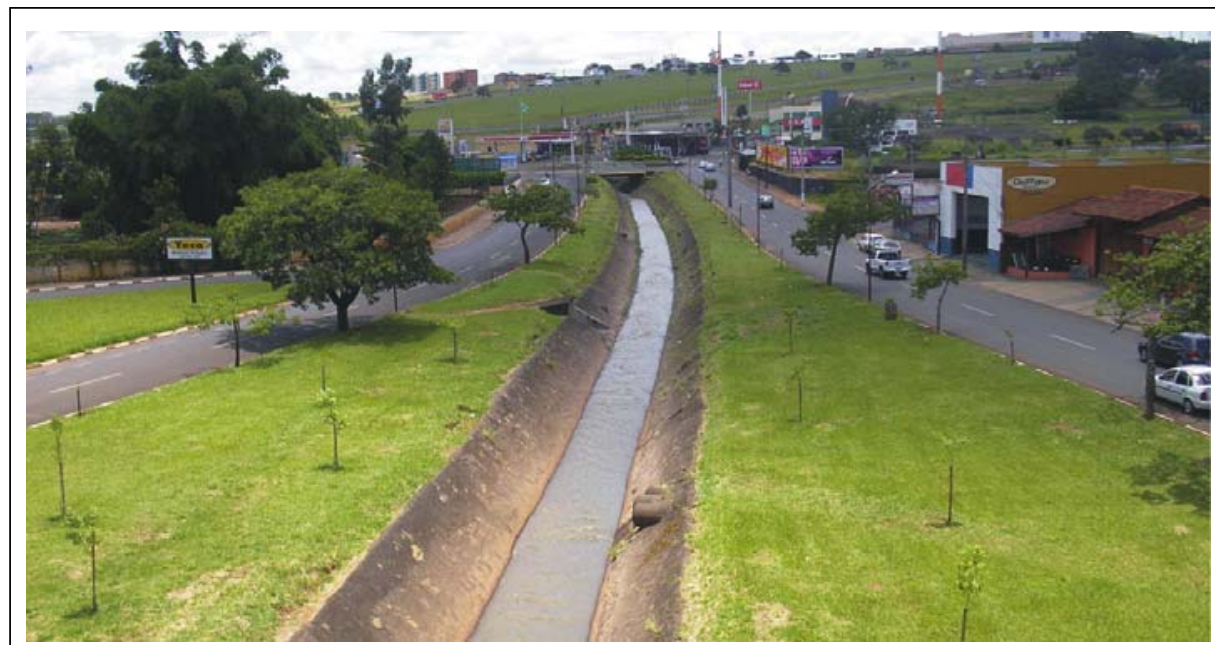

Figura 97. Vista atual da canalização do córrego do Cubatão, no encontro com o córrego dos Bagres. 
- ÁREA ENTRE LOTEAMENTOS JARDIM FRANCANO E VILA ROSELÂNDIA E A AVENIDA RIO BRANCO

Área situada em propriedade da empresa Amazonas, que a utilizou na ampliação de sua unidade industrial.

Podemos verificar, portanto, que uma parcela significativa das áreas previstas no Plano, ainda que parcialmente, foram transformadas em patrimônio público, embora sua destinação, uso e ocupação não tenham sido, em sua totalidade, respeitados integralmente na forma proposta pelo Plano Diretor. Mesmo assim, a implantação em parte das áreas de algum tipo de tratamento paisagístico e urbanístico permitiu sua integração às regiões consolidadas da cidade, ampliando os espaços livres da zona urbanizada e, em boa parte, também ampliando as áreas verdes da cidade.

\section{MODERNIZAÇÃO ADMINISTRATIVA: FORMAÇÃO DE QUADROS PARA A PREFEITURA}

A estrutura administrativa do Município de Franca, tal como subsistia até o golpe militar de 1964, era bastante tradicional e comum às demais prefeituras das pequenas cidades naquele período: um pequeno conjunto de departamentos, subordinados diretamente ao gabinete do prefeito municipal, que tratavam de assuntos específicos para cada pasta: educação, saúde, finanças, administração, obras e viação, eram os principais setores da gestão municipal. Os serviços de abastecimento de água e esgotamento sanitário eram mantidos por uma autarquia, o Serviço Autônomo de Água e Esgoto de Franca (SAEF).

Apenas em 1958 havia sido criado o Departamento de Viação e Obras Públicas, através da lei municipal n. 687, de 12 de fevereiro, com uma seção de Urbanismo e Obras Particulares, cuja competência incluía o Plano Urbanístico da cidade e de sua expansão, embora não se tenha qualquer notícia de sua feitura. (CHIQUITO, 2006)

Os moradores da cidade enfrentavam uma situação dramática, com o virtual colapso dos serviços de água e saúde a partir do rápido incremento de sua urbanização (entre 1950 e 1960, a população urbana de Franca tinha quase duplicado, crescendo $82,9 \%$ ), decorrentes da industrialização e migração, que drenou boa parte da população de pequenas cidades vizinhas (FERREIRA, 1989).

A necessidade de expansão dos serviços essenciais prestados pela Municipalidade levou o governo local a concluir pela necessidade de realizar uma ampla reforma administrativa na Prefeitura e investir nela, idéia que já vinha sendo gestada desde o início dos anos 60. O então prefeito Flávio Rocha (1959-1963) chegou a enviar dois servidores para um curso no IBAM, no Rio de Janeiro, visando qualificá-los a desenvolver uma ampla reforma administrativa, que foi efetivamente enviada à Câmara Municipal, porém somente aprovada em novembro de 1963, no final de sua gestão, logo após a vitória de Hélio Palermo. Posteriormente, esta estrutura administrativa foi modificada, já no âmbito do novo Plano Diretor, a partir dos trabalhos do GPI, que iriam elaborar as propostas de reforma administrativa e sua efetiva implantação. $\mathrm{O}$ 
prefeito Hélio Palermo (1964-1969) reuniu as condições políticas e administrativas para iniciar de fato a modernização da gestão municipal, dentro de um conjunto de atividades que faziam parte do contrato com o GPI: Hélio fez aprovar uma legislação que instituía uma nova estrutura administrativa, que incluía a criação de novos cargos técnicos cujo acesso seria realizado através de concurso público, modernizou o cadastro técnico municipal e elaborou um Plano Diretor para a cidade. Ou seja, reuniu e deu conseqüência às bases de uma nova estrutura para a gestão administrativa. (FERREIRA, 2004)

Foi também durante seu primeiro mandato, numa linha de modernização da administração municipal, que se realizou em 1966 um concurso público de anteprojetos de arquitetura, vencido pelos arquitetos paulistanos José Guilherme Savoy de Castro e Antônio Sérgio Bergamin, visando construir o novo Paço Municipal, erguido nos altos da Cidade Nova ${ }^{26}$.

O projeto de Castro e Bergamin vinculou-se, como afirma XAVIER et allii (1983), à chamada modernidade da arquitetura racionalista, por seu pleno domínio da tecnologia do concreto armado. O edifício, que ocupava toda uma quadra, previa um bloco horizontal para o atendimento ao público, um vertical para abrigar todas as secretarias, as instalações da Câmara municipal e um centro cultural. No entanto, apenas o bloco administrativo e a Câmara municipal foram iniciados. Sua construção, porém, não se concluiu no primeiro mandato de Hélio, tendo sido seu sucessor Lancha Filho o responsável pela mudança do Paço para o prédio, por volta de 1971, mesmo inacabado ${ }^{27}$.

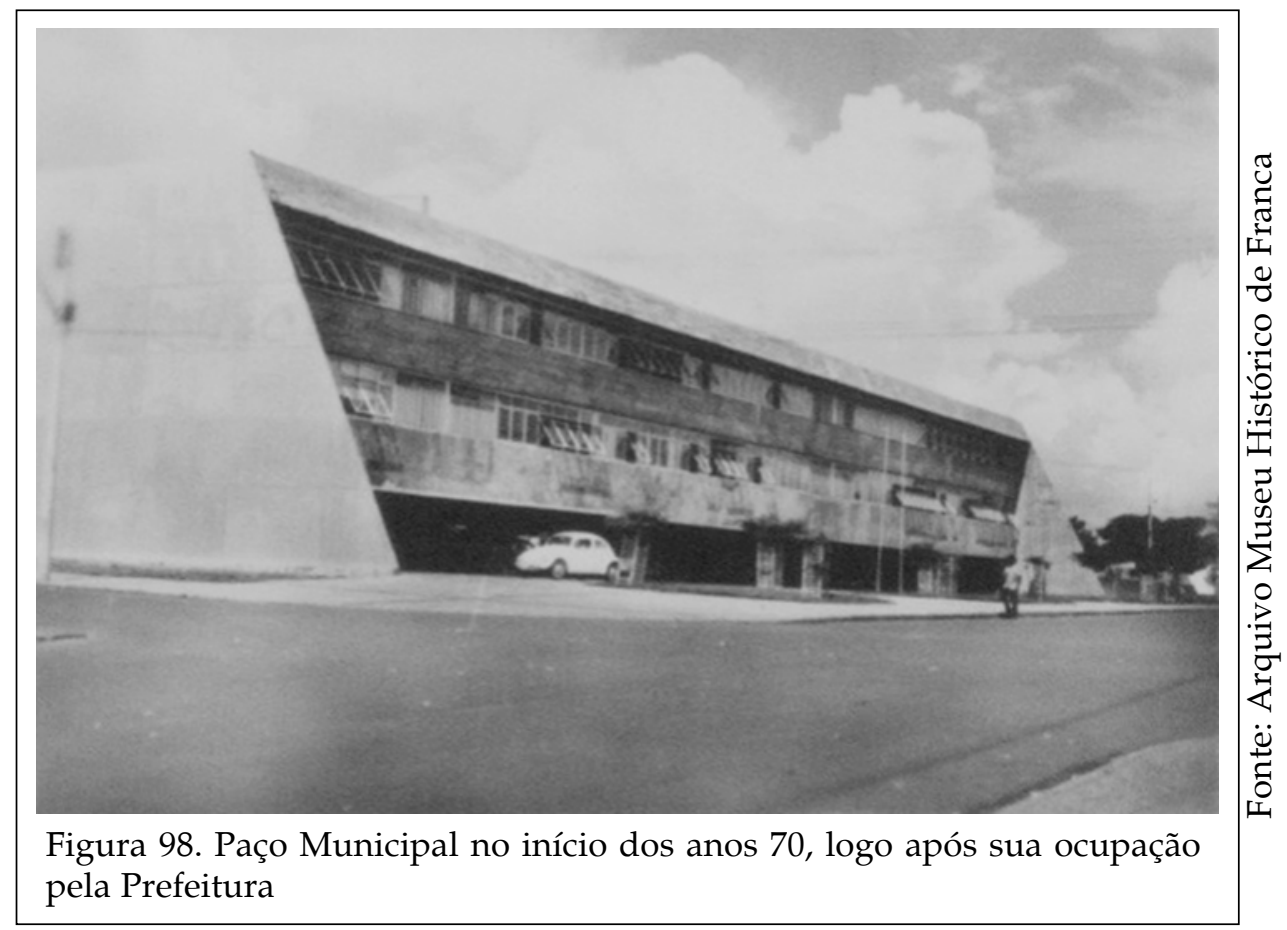

${ }^{26}$ COMÉRCIO DA FRANCA, 15 de janeiro de 1966, p.8.

${ }^{27}$ Informações obtidas na entrevista com José Eurípedes de Oliveira Ramos, em 16/10/2003, Franca-SP. 
É verdade que o período do primeiro governo de Hélio Palermo foi um período de grandes mudanças para a administração pública. Uma nova lei federal, ( $n^{\circ}$. 4320/ 1964), aprovada nos últimos dias do governo de João Goulart regulamentou a elaboração do orçamento público, que passou a fazer parte da rotina dos municípios. Sua hermética forma representou mais um passo importante para a tecnoburocracia assumir relevância na administração pública, pois ilegível e complexa para os leigos (IANNI,1971).

Logo no início, o regime criado pelo golpe militar de 1964 causou também profundas transformações administrativas. A implantação pelos municípios de um processo denominado planejamento local integrado era um dos objetivos do novo governo, casando recursos públicos com investimentos necessários à superação dos "problemas urbanos" detectados diagnósticos técnicos, onde a razão técnica passava a ser o fator determinante em detrimento da política, o que foi a tônica do período, eivada de um certo positivismo, de superação dos problemas urbanos e sociais pela ciência e pela técnica (RIBEIRO e CARDOSO, 1990).

(CASALI, 1983) afirma que é fundamental neste processo a contribuição de Max Weber, que salienta o fenômeno das transformações provocadas pelo processo de urbanização no sentido de uma racionalização da religião, na medida em que favorece o desenvolvimento de um corpo de especialistas, incumbidos da gestão material e intelectual das atividades religiosas, que vão se transmudando para as demais instituições do mundo capitalista europeu. Com isso, os princípios da racionalidade tecnocrática vão surgir como elementos da ideologia do Estado do capital monopolista, ou seja, "o tecnocratismo surge como forma específica do imaginário social enquanto fórmula de legitimação do campo do poder do capital monopolista. A racionalidade técnica e neutra viabiliza não apenas a tomada de decisões com exclusão de consulta e ou legitimação popular, como também condiciona diretamente a participação e o apoio dos setores não-vanguardistas ou associados da elite dominante" (CASALI:1983:51).

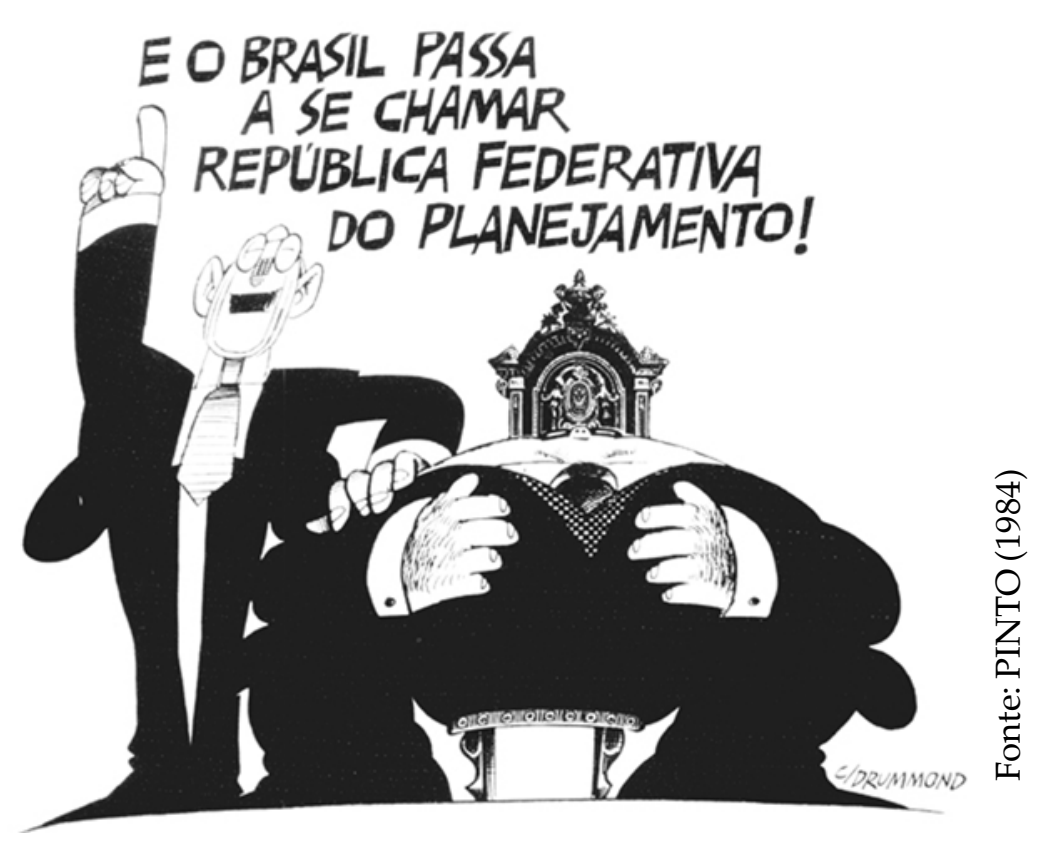

Figura 99. A importância do planejamento durante o Regime Militar foi objeto de ironia pelo cartunista Ziraldo 
Assim, obedecendo aos pressupostos desta racionalização administrativa preconizada pelo governo federal, dá-se a aprovação da lei municipal $\mathrm{n}^{\circ}$. 1.559 , de novembro de 1967, produzida pelo GPI, instituindo o Sistema de Planejamento do Desenvolvimento Integrado de Franca, cujos objetivos, dentre outros aspectos, estão assim descritos:

- imprimir crescente racionalidade e dinamismo à ação executiva da Administração Municipal;

- conseguir que o desenvolvimento do Município se processe de forma racional e equilibrado;

- programar adequadamente os investimentos, a fim de assegurar melhoria de sua produtividade e racionalidade na execução de obras e serviços;

- assegurar permanente racionalidade de todo o sistema administrativo, direto e indireto do Município, mediante a simplificação das rotinas e procedimentos;

Ou seja, todo o aparato ideológico que transparece na legislação municipal instituída naquele momento histórico tem, subjacente, a idéia weberiana de que deveria haver uma racionalidade na ação governamental que, substituindo a política pela técnica, seria capaz de promover o desenvolvimento harmônico e integrado das estruturas locais.

Mais ainda, a lei exige que

para assegurar eficácia operacional ao sistema de planejamento do desenvolvimento municipal integrado, é obrigatória existência de órgão de planejamento na Prefeitura de Franca, componente de sua estrutura administrativa, subordinado diretamente ao Prefeito, ${ }^{28}$

avocando para uma estrutura técnica formal e obrigatória a responsabilidade pela coordenação geral das ações do governo. Evidentemente, dentro de suas obrigações, este novo organismo seria responsável pela "identificação das fontes de financiamento e aplicação racional e adequada dos recursos municipais", e exigir dos demais organismos de governo a apresentação de planos e projetos tecnicamente elaborados, para incluí-los no orçamento municipal.

Clarifica-se, desta maneira, um processo de institucionalização e legitimação da tecnoburocracia, para dar suporte "técnico e científico" às atividades da Prefeitura Municipal. A lei impõe uma pretensa "racionalização do sistema administrativo municipal", que deverá "atender sempre as exigências de racionalidade e produtividade no sentido do atendimento das funções do Município". Para isso, dentre outras providências, caberia realizar:

- o estudo sistemático do sistema administrativo, a fim de corrigir possíveis desvios em relação à ação do governo municipal;

\footnotetext{
${ }^{28}$ Lei municipal n. 1559/1967.
} 
- racionalização permanente da organização e funcionamento dos órgãos e entidades da administração municipal;

- modificação nas atribuições e rotinas de trabalho;

O novo órgão de planejamento deveria ser dirigido, obrigatoriamente, por um especialista de reconhecida experiência em planejamento, assegurando-se desta forma a um tecnoburocrata a direção do organismo que seria ligado diretamente ao Prefeito, assessorando-o na condução do governo.

Logo após a aprovação da lei que organizou o sistema de planejamento, duas novas leis trataram de criar as condições administrativas e organizacionais para que a Prefeitura pudesse dar conta das tarefas previstas pelo seu planejamento: a lei 1.560, de 1 de dezembro de 1967, que tratava da reorganização administrativa e a lei 1.596, de 11 de março de 1968, que dispôs sobre o quadro de pessoal da Prefeitura, estabelecendo um quadro com as bases de salários dos cargos públicos, assim como também um prazo para a realização de concursos públicos de acesso à carreira do serviço público municipal.

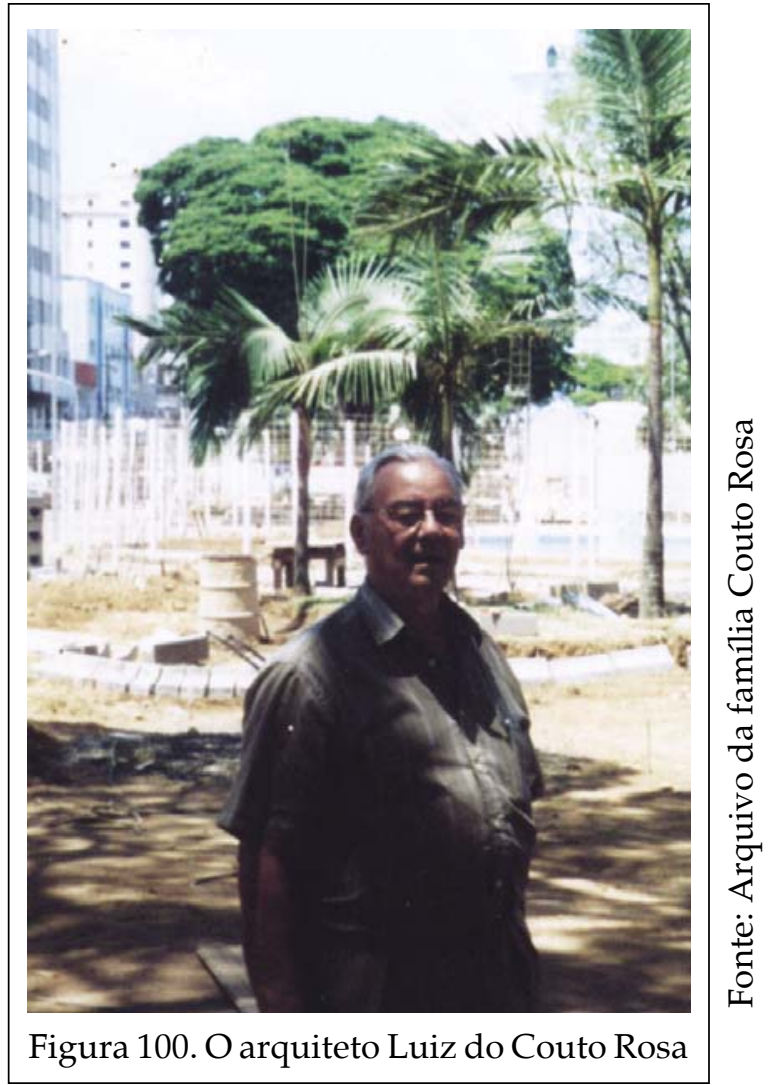





\section{CONCLUSÕES}

Os resultados desta pesquisa permitem demonstrar que as principais críticas encontradas na literatura sobre o planejamento urbano desenvolvido durante o período de existência do SERFHAU e por ele financiado, não correspondem exatamente ou não encontram referência direta com os estudos elaborados pelo GPI para o município de Franca, nem tampouco com a efetiva experiência do processo de elaboração e implementação do Plano Diretor de Desenvolvimento Integrado local elaborado sob sua égide.

Embora o planejamento desenvolvido a partir do Plano de Franca nunca assumisse o caráter integrado que sua concepção inicial indicava, ele também não se reduziu exclusivamente aos aspectos físico-territoriais comumente admitidos, ou à sua absoluta inexistência prática e/ou abandono, relativizando as críticas encontradas na literatura. A repercussão da aplicação do Plano, conforme analisamos, mostra ter ocorrido uma clara opção nas ações da Prefeitura pela consolidação de uma proposta de cidade que interessava às elites dominantes emergentes, a industrial calçadista, em detrimento da elite agrária que prevalecera até então. A ascensão de uma dinâmica e próspera indústria calçadista na cidade, que demandava mão de obra em abundância, áreas para expansão de novas empresas e para moradia das classes trabalhadoras e infra-estrutura para produzir vão se refletir no processo decisório sobre o espaço urbano. Investe-se pesadamente em infra-estrutura para a indústria, implantando-se um distrito industrial totalmente com recursos próprios da municipalidade, criando-se inclusive uma empresa específica com capital majoritariamente público para o empreendimento (o DINFRA S.A). A pesquisa revela que ao mesmo tempo, enquanto não se consolida o processo de planejamento e de estruturação de um setor de planejamento e dos instrumentos de controle de uso e ocupação do solo, não há freios para a expansão da cidade: a idéia vigente é propiciar lotes em profusão para os trabalhadores e para a expansão da indústria por toda a cidade, sem grandes restrições de zoneamento de uso e ocupação do solo, utilizando o discurso da pretensa "vocação horizontal" da cidade. Ou seja, apesar da proposta radical do Plano Diretor de estancar a expansão horizontal e de incentivar a ocupação das áreas com disponibilidade de infra-estrutura, por conta da própria dificuldade da prefeitura atender a demanda, os interesses imobiliários de 
setores da sociedade, como a indústria calçadista e os empreendedores imobiliários, que envolviam alguns dos prefeitos do período pesquisado, foram atuantes no sentido de propiciar a produção de lotes e de uma expansão horizontal da cidade que faz surgir novos vazios urbanos e agrava as dificuldades da municipalidade em atender as necessidades locais e ampliam os problemas ambientais já detectados naquela época, como as erosões. De certa forma, esta atuação de políticos e setores empresariais agiu no sentido da construção e legitimação de um discurso de uma identidade local de forte caráter ideológico, até mesmo porque, ainda hoje, este discurso das lideranças e elites locais sempre procura apresentar como sendo um dos aspectos positivos da cidade a inexistência de favelas (até o momento), embora aspectos sociais como os indicadores de pobreza e a iniqüidade da divisão de renda local em nada sejam muito diferentes do restante do país.

O diagnóstico permite também revelar que o plano aborda a questão econômica com uma visão muito mais ampla que os simples limites municipais, ao colocar em questão as possibilidades concretas de inserção internacional da produção industrial calçadista da cidade, via exportações, utilizando como instrumento para ampliar seus mercados a implantação de uma Feira calçadista. Estas propostas de fato se viabilizaram, pois a cidade se transformou em plataforma exportadora de calçados e a feira se transformou na Francal, hoje referência internacional, saindo inclusive do âmbito espacial da cidade, pois é realizada atualmente na capital do estado de São Paulo. O papel do processo de elaboração do Plano para esta inserção é inegável, pois a introdução do tema da industrialização e dos caminhos para sua consolidação no debate político local vai se ampliar consideravelmente, com propostas concretas de ação para o poder público local e para o empresariado quando da elaboração do Plano, e as medidas para a efetiva implantação do Distrito Industrial vão se iniciar a partir da aprovação da lei do Plano Diretor. Além disso, o Plano incorporou demandas locais, como uma estrutura física para a realização de uma feira calçadista, estratégia que se revelou acertada para o incremento de vendas para os mercados externo e interno.

A aplicação das diretrizes do Plano também se valeu de uma contingência política local, pois a descontinuidade administrativa, comum entre adversários políticos na tradição brasileira, não se verificou de maneira expressiva, restringindo-se mais ao plano discursivo-ideológico. Mesmo prefeitos manifestamente opositores em termos da política local, como Hélio Palermo e Lancha Filho, ou Sidnei Rocha e Maurício Sandoval Ribeiro, sem exceção, todos vão utilizar propostas do Plano e dar continuidade à sua implementação, como verificamos no caso do Distrito Industrial, da pedestrianização do centro comercial principal, da ampliação e modernização do sistema viário como instrumento de abertura de novos eixos de ocupação urbana e novas centralidades para expansão da cidade, da construção de parques urbanos e recuperação ambiental de voçorocas, dentre outros aspectos.

Apesar das limitações dos instrumentos disponíveis para os municípios naquele período, num contexto de autoritarismo e centralização federal, o Plano Diretor Físico de Franca, da maneira como aprovado, se não foi certamente capaz de constituir uma experiência de planejamento integrado tal como pressupunha sua teoria, foi capaz de nortear a expansão urbana, consolidando e integrando ações políticas locais e 
instrumentos de controle e da produção do espaço urbano, institucionalizando certos aspectos fundamentais do sistema de aprovação de novos loteamentos (criando regras para o fornecimento de diretrizes urbanísticas antes mesmo da lei federal 6.766/79, para a realização e fiscalização das obras de infra-estrutura, assim como redefinindo o dimensionamento do sistema viário e dos equipamentos públicos) e de expansão da cidade.

Outro aspecto importante a considerar é que o processo de elaboração do Plano permitiu constituir e consolidar uma estrutura permanente de planejamento na administração municipal, bem como capacitar um corpo técnico e burocrático qualificado para a administração pública, outro fator importante para os aspectos de continuidade administrativa apontados. A partir da constituição da Assessoria de Planejamento, cujo primeiro ocupante foi o arquiteto Luiz do Couto Rosa, servidor de carreira do Município, estruturou-se ao longo dos anos uma Secretaria de Planejamento que até hoje permanece no organograma da Prefeitura, permitindo a qualificação e capacitação de outros técnicos municipais, além de acumular uma memória de planos e projetos físicos. Couto Rosa foi, além de assessor de Planejamento, secretário de Planejamento e presidente da Empresa Municipal de Desenvolvimento de Franca, um dos técnicos que coordenou a equipe local do Plano Diretor, fazendo a interlocução com o GPI, e sua carreira perpassou o mandato de cinco prefeitos. Outros técnicos foram José Suavinho e Marco Aurélio Résio, que iniciaram a carreira como escriturários, no período de elaboração do Plano, e chegaram a ser secretários de Finanças e Administração do Município, respectivamente.

Desta maneira, pode-se perceber a existência de dois elementos conjugados que permitiram a continuidade do processo de planejamento e implantação do Plano Diretor: de um lado, em 32 anos (1964-1996), apenas cinco pessoas exerceram o cargo de prefeito de Franca, revezando-se três deles em dois mandatos não consecutivos, inclusive porque não havia o instituto da reeleição (Hélio Palermo, Maurício Sandoval Ribeiro e Ary Pedro Balieiro); destaque-se ainda que Ary Balieiro foi vice e secretário de Planejamento de Sidnei Rocha que, por sua vez, foi assessor de Esportes na segunda gestão de Hélio Palermo; de outro, técnicos como Couto Rosa, Suavinho e Résio fizeram parte dos escalões superiores em todos esses governos, até suas aposentadorias no início dos anos 1990, assim como Teixeira e o autor até os dias de hoje, o que permite inferir a existência de um grau bastante alto de continuidade e de memória de planos e projetos elaborados pela Prefeitura.

Como bem lembra RODWIN (1967:45),

\footnotetext{
"estudos e planos não são feitos por máquinas, mas por seres humanos, que pensam, dispõem, discutem e experimentam suas idéias. As tarefas a desempenhar ficam sempre muito mais claras em retrospecto. As decisões tomadas podem trazer resultados e estes podem ajudar a formular decisões adicionais".
}

Ou melhor, as ações definidas num plano, que sempre são julgamentos provisórios ou mesmo incompletos, ajudarão a formular o futuro. Se as pessoas que experimentaram ou criaram as propostas acreditam em sua viabilidade, elas ajudarão 
a executá-las. Queremos reafirmar com isso que o Plano Diretor de Franca e suas propostas, de certo modo, foram utilizados pelos os setores predominantes na economia e política local, como o empresariado coureiro-calçadista, os empreendedores imobiliários de loteamentos e o comércio da região central, através de suas entidades representativas, como a Associação Comercial e Industrial de Franca - ACIF e o Sindicato da Indústria de Calçados, durante o longo processo de elaboração e de sua implantação, até mesmo enquanto discurso ideológico e justificativo das políticas adotadas, para que a cidade fosse preparada para atender ao capital imobiliário e industrial, não como a realização pura e simples de métodos e técnicas cuja neutralidade inexiste, mas como deliberada política.

O próprio discurso dos ex-prefeitos, sobre uma pretensa "vocação de crescimento horizontal" é a expressão mais acabada desta visão sobre a cidade enquanto espaço de dominação e acumulação do capital, gerando grandes áreas vazias e a formação de um mercado imobiliário restrito e fortemente especulativo, de exclusão social e seletividade no fornecimento de infra-estrutura e serviços públicos, como mostram estudos recentes (FELDMAN, 2002 e CHIQUITO, 2006).

Portanto, o discurso corrente na literatura, afirmando que se considerarmos apenas o nível local de planejamento urbano, justamente o que mais se desenvolveu na década de 1960 sob o estímulo do extinto SERFHAU, que teria sido irrelevante a influência do planejamento na transformação concreta das cidades, cujo processo de elaboração seria puramente tecnocrático, distanciado da sociedade local, não pode ser aceito sem um aprofundamento e realização de novos estudos e verificações de sua repercussão naquele período. Como a maioria dos estudos se refere aos centros metropolitanos, onde os planos em sua maioria limitaram-se a exaustivos diagnósticos técnicos, divorciados das reais possibilidades de intervenções concretas do poder público local, pode-se considerar que nas cidades de menor porte esta possa não ser a mesma realidade.

O papel desempenhado por aquele organismo federal e pela empresa de consultoria contratada para elaborar o plano de Franca, no mínimo, possibilitou a formação de quadros técnicos para a gestão da cidade, bem como o desenvolvimento de metodologias de planejamento que não foram ainda totalmente superadas no quadro atual. O desvendamento das ações e da história do GPI, inclusive como estratégia de sobrevivência de quadros técnicos da esquerda oposicionista ao regime militar, bem como sua contribuição à formulação de metodologias de planejamento e a formação de profissionais para o setor público e para a universidade não pode ser desprezada ou esquecida. O aprofundamento das pesquisas e análises destas experiências se apresenta como necessária inclusive porque, nos últimos anos, a partir da exigência da lei federal que criou o Estatuto da Cidade, centenas de municípios brasileiros retomaram a elaboração de Planos Diretores, cuja eficácia ainda não foi testada, nem suas metodologias objeto de comparações mais apuradas com aquelas fruto da experiência do SERFHAU.

Na medida em que verificamos nesta experiência que importantes aspectos das propostas do Plano Diretor foram realizados em considerável parcela, orientando a ação e os investimentos públicos durante largo espaço de tempo, no sentido de estruturar 
a cidade para abrigar o desenvolvimento industrial e a necessária mão de obra intensiva para a produção calçadista, o caso de Franca pode ser exemplar para abrir novas perspectivas de pesquisa daquele período. Mesmo porque o novo Plano Diretor de Franca, transformado em lei em 2003, já sob a vigência do Estatuto da Cidade, retoma velhas questões que o Plano Diretor de 1972 já considerava e que não foram enfrentadas: o excessivo crescimento horizontal da cidade e o agravamento das condições de infraestrutura urbana, em especial a manutenção do sistema viário e da limpeza pública, a criação de grandes vazios na malha urbana existente gerando deseconomias, são objeto de tratamento específico através da criação de macrozonas de edificação e/ou urbanização compulsórias, sob pena de aplicação do chamado IPTU progressivo. As novas voçorocas surgidas em decorrência da ausência de um eficiente sistema de drenagem urbana ou o processo de envelhecimento e decadência da região central deverão ser enfrentadas por Programas de Gestão Integrada, instrumentos novos para velhos problemas. Com uma significativa e importante diferença para os tempos do SERFHAU: o processo de desmonte do Estado brasileiro operado desde o final do século $X X$, o agravamento das dificuldades econômico-financeiras das municipalidades e o aumento da participação, das demandas e reivindicações da sociedade nas políticas públicas sob a democracia tornam a implementação dos novos Planos desafio e incógnita que o conhecimento do passado pode ajudar a superar. 



\section{BIBLIOGRAFIA}

AB'SABER, A.N. (1969). Geografia e planejamento. São Paulo: Ed. Universidade de São Paulo. (Série geografia e planejamento)

AB'SABER, A.N. (1975). O planalto de Franca: estudos básicos para planejamento regional. São Paulo: Ed. Universidade de São Paulo. (Série geografia e planejamento)

AMBROSIS, C. (1972). O planejamento local nos municípios do Estado de São Paulo. São Paulo: Cepam. (mimeo).

AMBROSIS, C.; MOREIRA, A.C.M.L. (1977). A rede urbana do Estado de São Paulo. São Paulo: Fundação Prefeito Faria Lima : CEPAM.

ARANTES, O.; VAINER, C.; MARICATO, E. (2000). A cidade do pensamento único: desmanchando consensos. Petrópolis: Vozes.

ASSAD, A.A. (1973). Curitiba: Revitalização de um centro urbano. Cj Arquitetura, São Paulo, n. 2, p.113-119, ago./out.

ASSOCIAÇÃO INTERNACIONAL DE ADMINISTRADORES MUNICIPAIS (1964). Planejamento urbano. Rio de Janeiro: Fundação Getúlio Vargas.

AZEVEDO, E.A. (1976). Avaliação do planejamento municipal no Estado de São Paulo: relatório de pesquisa. São Carlos: USP/EESC.

BARBOSA, A.S. (1997). Política e modernização no interior paulista. 205f. Dissertação (Mestrado) Faculdade de História, Direito e Serviço Social, Universidade Estadual Paulista “Júlio de Mesquita Filho", Franca, 1977.

BENTIVOGLIO, J.C. (1997). Trajetória urbana de Franca: centro (1805-1995). Franca: Ed. UNESP.

BERTOLINO, O. Diógenes Arruda: "um comunista danado". Disponível em: <http:// www.vermelho.org.br/diario/2004/0706/0706_arruda.asp>. Acesso em: 29 mai. 2005.

BIRKHOLZ, L.B. (1964). Planos diretores no Estado de São Paulo e sua implantação. 201f. Tese (Livredocência) - Faculdade de Arquitetura e Urbanismo, Universidade de São Paulo, São Paulo, 1964.

BIRKHOLZ, L.B. (1989). O centro de pesquisas urbanas da FAUUSP: uma experiência pioneira de planejamento territorial urbano, de 1957 a 1972. In: SEMINÁRIO PLANO DIRETOR MUNICIPAL, 1989, São Paulo. Anais... São Paulo: FAUUSP. p. 21-29.

BIRKHOLZ, L.B.; BRUNA, G.C. (Org.). (1980). Introdução ao planejamento. São Paulo: FAU.

BONDUKI, N. (Org.). (1996). Habitat: as práticas bem-sucedidas em habitação, meio ambiente e gestão urbana nas cidades brasileiras. São Paulo: Studio Nobel. 
BONDUKI, N. (1998). Origens da habitação social no Brasil: lei do inquilinato. São Paulo: Estação Liberdade.

BONDUKI, N. (2000). Habitar São Paulo: reflexões sobre a gestão urbana. São Paulo: Estação Liberdade.

BRASIL. Serviço Federal de Habitação e Urbanismo. (1967). Áreas metropolitanas e desenvolvimento integrado no Brasil. Rio de Janeiro: SERFHAU.

BRASIL. Serviço Federal de Habitação e Urbanismo. (1969). Sistema Nacional de Desenvolvimento Urbano e Local no Brasil. Rio de Janeiro: SERFHAU.

BRASIL. Ministério do Interior. (1971). Instruções para elaboração e apresentação dos relatórios preliminares de desenvolvimento local integrado. Brasília, DF.

BRASIL. Serviço Federal de Habitação e Urbanismo. (1971). Instruções experimentais para elaboração e apresentação dos planos de ação imediata de desenvolvimento local integrado. Rio de Janeiro: SERFHAU.

BRASILEIRO, A.M. (1981). Políticas sociais para áreas urbanas: possibilidades. DINIZ, E. Políticas públicas para áreas urbanas. Rio de Janeiro: Zahar.

BRUNA, G.C. (Org.) (1983). Questões de organização do espaço regional. São Paulo: Nobel/Edusp.

BUENO, J.C.L. (1979). Estudos sobre a evolução da Lei de zoneamento de São José do Rio Preto. 102f. Dissertação (Mestrado) - Escola de Engenharia de São Carlos, Universidade de São Paulo, São Carlos, 1979.

CALIL JR., O.; SANCHES, K.; FERRANINI JR., L. (2001). O moderno marca a expansão da cidade: uma análise das propostas urbanísticas em Ribeirão Preto nas décadas 50-80. In: IV SEMINÁRIO DOCOMOMO BRASIL. 2001, Viçosa. Anais... p.23-24. Viçosa:DOCOMOMO.

CAMPOS, R. (1994). A lanterna na popa: memórias. Rio de Janeiro: Topbooks .

CAMPOS FILHO, C. M. et al. Planejamento urbano: do populismo aos dias atuais. Espaço e Debates, São Paulo, v. 1, n. 4, p. 137-173, 1981.

CANO, W. (1977). Raízes da concentração industrial em São Paulo. São Paulo: Difel.

CASALI, P.A.A. (1983). A questão tecnocrática: campo intelectual - tecnocrático e o discurso dos agentes de planejamento. Revista Espaço e Debates. São Paulo. Ano 3, n.9.p.42-65.

CHIQUITO, E.A. (2006). Expansão urbana e meio ambiente nas cidades não-metropolitanas: o caso de Franca-SP. 182 f. Dissertação (Mestrado) - Escola de Engenharia de São Carlos, Universidade de São Paulo, São Carlos, 2006.

CINTRA, A.O.; HADDAD, P. R. (Org.). (1978). Dilemas do planejamento urbano e regional no Brasil. Rio de Janeiro: Zahar.

COLE, H.J. (1967). Desenvolvimento metropolitano integrado no Brasil. Rio de Janeiro: SERFHAU. p.11-26.

COMÉRCIO DA FRANCA. Franca: Empresa Francana Editora de Jornais, 1963-1973. Diário.

COUTO, R.C. (1998). História indiscreta da ditadura e da abertura - Brasil: 1964-1985. Rio de Janeiro: Record.

DEÁK, C.; SCHIFFER, S.R. (Org.) (1999). O processo de urbanização no Brasil. São Paulo: Edusp.

DEBIAGGI, M.C. (1985). O processo de uso e ocupação do solo. CASTRO, A.E. et al. Política urbana: a produção e o consumo da cidade. Porto Alegre: Mercado Aberto. (Série tempo de pensar).

DIARIO DA FRANCA. Franca: Diário da Franca Ltda, 1973-1996. Diário.

DOSSIÊ dos mortos e desaparecidos políticos a partir de 1964. (1996). São Paulo: Imprensa Oficial do Estado de São Paulo. 
FAISSOL, S. (1971). Tipologia das cidades e regionalização do desenvolvimento econômico: um modelo de organização espacial para o Brasil. Boletim Geográfico, Rio de Janeiro, ano 30, n. 223, p.4-18, jul./ ago.

FAORO, R. (1973). Os donos do poder: formação do patronato político brasileiro. Porto Alegre: Globo. FAUSTO, B. (1999). História do Brasil: São Paulo: EDUSP.

FELDMAN, S. (coord.) (2002). Programas de gestão integrada para o município de Franca - PGI. (Relatório final) São Carlos: FAPESP / EESC-USP.

FELDMAN, S. (2005a). Planejamento e zoneamento: São Paulo 1947-1972. São Paulo: EDUSP.

FELDMAN, S. (2005b). Arranjo SERFHAU: assistência técnica aos municípios/órgãos de planejamento/ empresas de consultoria consultiva. In: ENCONTRO NACIONAL DA ANPUR, 11. 2005, Salvador. Planejamento, soberania, solidariedade: perspectivas para o território e a cidade: programação geral e caderno de resumos. Salvador: Anpur.

FERRARI, C. (1977). Curso de planejamento municipal integrado. São Paulo: Livraria Pioneira.

FERREIRA, M. (1983). Franca, itinerário urbano. Franca: Laboratório das Artes.

FERREIRA, M. (1989). O espaço edificado e a indústria calçadista de Franca. 163f. Dissertação (Mestrado) - Escola de Engenharia de São Carlos, Universidade de São Paulo, São Carlos, 1989.

FERREIRA, M. (2004). Distrito industrial de Franca: uma idéia a procura de um lugar. In: SEMINÁRIO DA HISTÓRIA DA CIDADE E DO URBANISMO, 8., 2004, Niterói, RJ. Anais... Rio de Janeiro: UFF. 1 CD-ROM.

FOLLIS, F. (2004). Modernização urbana na “Belle Époque" paulista. São Paulo: Ed. Unesp.

FRANCA. Legislação Municipal. Disponível em: <http://200.210.7.10/legislacao_municipal.htm>. Acesso em: 2005-2007.

FRANCISCONI, J.G.; SOUZA, M.A.A. (1976). Política nacional de desenvolvimento urbano: estudos e proposições alternativas. Brasília, DF: IPEA/IPLAN.

FUENTES, M.C.S. (2006). Conjunto residencial Parque Vicente Leporace: marco de novas concepções urbanísticas na trajetória do BNH. 178 f. Dissertação (Mestrado) - Programa de Pós-Graduação em Engenharia Urbana, Universidade federal de São Carlos, São Carlos, 2006.

FUNDAÇÃO INSTITUTO BRASILEIRO DE GEOGRAFIA E ESTATÍSTICA. (1975). Franca. SP. Coleção de Monografias n. 606. 30 p. Rio de Janeiro: IBGE. nov.

FUNDAÇÃO PREFEITO FARIA LIMA. (1969) PDDI: Plano Diretor de Desenvolvimento Integrado. São Paulo: CEPAM.

FUNDAÇÃO PREFEITO FARIA LIMA. (1999). O município no século XXI: cenários e perspectivas. São Paulo, CEPAM.

GARCIA, R.C. (1996). Aglomerações setoriais ou distritos industriais: um estudo das indústrias têxtil e de calçados no Brasil. 146 f. Dissertação (Mestrado) - Instituto de Economia da Unicamp, Universidade de Campinas, Campinas, 1996.

GASPARI, E. (2003). A ditadura derrotada. São Paulo: Companhia das Letras

GOMES, C. (1973). "Renovação" urbana? CJ-Arquitetura, Rio de Janeiro, n. 2, p.53-58, ago./out.

GONÇALVES, D. (Coord.). (2001). História das cidades e teoria do planejamento. Viçosa: Universidade Federal de Viçosa.

GONÇALVES, M.F. (1994). Novas configurações no desenvolvimento urbano paulista. Revista Espaço e Debates, São Paulo, ano 14, n.38, p. 39-53. 
GONÇALVES, M.F. (Org.). (1995). O novo Brasil urbano: impasses, dilemas, perspectivas. Porto Alegre: Mercado Aberto.

GONÇALVES, M.F.; BRANDÃO, C.A.; GALVÃO, A.C. (Org.). (2003). Regiões e cidades, cidades nas regiões: o desafio urbano-regional. São Paulo: Ed. Unesp/Anpur.

GONDIM, L.M.P. (Org.). (1991). Plano Diretor e o município: novos tempos, novas práticas. Rio de Janeiro: IBAM.

GORDILHO-SOUZA, A. (Org.). (1997). Habitar contemporâneo: novas questões no Brasil dos anos 90. Salvador: Universidade Federal da Bahia/Faculdade de Arquitetura/Lab-Habitar.

GORENDER, J. (1987). Combate nas trevas: a esquerda brasileira: das ilusões perdidas à luta armada. São Paulo: Ática.

GRUPO DE PLANEJAMENTO INTEGRADO. [196-]. Planejamento Integrado na Região de Franca. São Paulo. (mimeo)

GRUPO DE PLANEJAMENTO INTEGRADO. (1971). Plano Diretor de Desenvolvimento Integrado. Votuporanga.SP.

IANNI, O. (1971). Estado e planejamento econômico no Brasil. Rio de Janeiro: Civilização Brasileira.

LAFER, B.M. (1975). Planejamento no Brasil. São Paulo: Perspectiva.

LAMPARELLI, C.; CAMARGO, A.R. (1978). Política e planejamento urbano no Brasil: relatório de estudos e pesquisas. São Carlos: EESC/USP.

LAMPARELLI, C.; ZAN, P. (1989). Novo conceito de Plano Diretor a partir da própria Constituição da República. In: SEMINÁRIO PLANO DIRETOR MUNICIPAL, 1989, São Paulo. Anais... São Paulo: FAUUSP.

LESSA, C. (1983). 15 anos de política econômica. 4. ed. São Paulo: Brasiliense. (Leituras afim).

LEME, M. B.; VENTURA, D.V.B. (2000). O calçadão em questão: 20 anos de experiência do calçadão paulistano. São Paulo: Belas Artes.

LEME, M.C.S. (1989). A reflexão e a prática do planejamento urbano: pontos para debate. In: SEMINÁRIO PLANO DIRETOR MUNICIPAL, 1989, São Paulo. Anais... São Paulo: FUPAM.

LEME, M.C.S. (Org.). (1999). Urbanismo no Brasil: 1895-1965. São Paulo: Studio Nobel : FAUUSP : FUPAM .

LEMOS, C.A.C. (1976). Cozinhas, etc. São Paulo: Perspectiva.

LODDER, C.A. (1978). O processo de crescimento urbano no Brasil. TOLEDO, A.H.P.; CAVALCANTI, M. (Org.). Planejamento urbano em debate. São Paulo: Cortez \& Moraes.

MARICATO, E. (1983). Política habitacional no regime militar. Rio de Janeiro: Vozes.

MARICATO, E. (1996). Metrópole na periferia do capitalismo: ilegalidade, desigualdade e violência. São Paulo: Hucitec.

MARICATO, E. (2001). Brasil, cidades. Rio de Janeiro: Vozes.

MELO, A.M. Mário Alves de Melo: depoimento [jan.2007]. Depoimento enviado ao jornal Comércio da Franca, depositado no Arquivo Histórico de Franca.

MELO, M.A.B.C. (1993). Municipalismo, nation-building e a modernização do Estado no Brasil. RCBS. São Paulo. Ano 8, n.23. p.26-42.

MODESTO, H. (1968). Problemas do planejamento urbano. Arquitetura. Rio de Janeiro. n.72/73, julho.p.19-22. 
NAPOLITANO, M. (1996). O regime militar brasileiro: 1964-1985. São Paulo: Atual.

NEGRI, B. (1996). Concentração e desconcentração industrial em São Paulo (1880-1990). Campinas, SP: Unicamp.

NEGRI, B.; PACHECO, C.A. (1993). Mudança tecnológica e desenvolvimento regional nos anos 90: da interiorização do desenvolvimento à nova dimensão espacial da indústria paulista. SUZIGAN, W.; COUTINHO, L. (Coord.). Projeto de desenvolvimento tecnológico e competitividade da indústria brasileira. Campinas: SCTDE/Pecamp/Unicamp - IE.

OLIVEIRA, D. (2003). Curitiba e o mito da cidade modelo. Curitiba: Ed. UFPR.

PAOLI, T.P. (1981). Um estudo da política urbana no Brasil. 1981. Dissertação (Mestrado) - Instituto de Filosofia e Ciências Humanas, Universidade de Campinas, Campinas.

PAGNONCELLI, D.; AUMOND, C.W. (2003). Cidades, capital social e planejamento estratégico: o caso Joinville. Rio de Janeiro: Elsevier Editora

PARTIDO DO MOVIMENTO DEMOCRÁTICO BRASILEIRO. (1982). Proposta de governo SidneiAry. Franca. (mimeo).

PINTO, Z.A. (1984). 20 anos de prontidão. Rio de Janeiro: Record.

PRATA, J.; BEIRÃO, N.; TOMIOKA, T. (1999). Sérgio Motta: o trator em ação. São Paulo: Geração Editorial.

PREFEITURA MUNICIPAL DE CAMPINAS. (1995). Plano Diretor. Campinas. SP.

PREFEITURA MUNICIPAL DE FRANCA. Grupo de Planejamento Integrado. [1971?a]. Plano de Desenvolvimento Integrado: diagnóstico. Franca.

PREFEITURA MUNICIPAL DE FRANCA. Grupo de Planejamento Integrado. [1971?b]. Plano de Desenvolvimento Integrado: plano de ação. Franca.

PREFEITURA MUNICIPAL DE FRANCA. Grupo de Planejamento Integrado. [1971?c]. Plano de Desenvolvimento Integrado: viabilidade do distrito industrial. Franca.

PREFEITURA MUNICIPAL DE FRANCA. Grupo de Planejamento Integrado. [1971?d]. Plano de Desenvolvimento Integrado: lei do plano diretor físico. Franca.

PREFEITURA MUNICIPAL DE FRANCA. Grupo de Planejamento Integrado. [1971?e]. Plano de Desenvolvimento Integrado: política de desenvolvimento físico. Franca.

PUGLIESI, H.M. (1967). Alguns aspectos da vida urbana em Franca oitocentista. 1967. Monografia (Licenciatura) - Faculdade de Filosofia Ciências e Letras, Franca.

PUPPI, I.C. (1980). Estruturação sanitária das cidades. São Paulo: CETESB.

REALIDADE. São Paulo: Abril, ano 7, n. 74, maio 1972. 286 p.

REZENDE, V. (1982). Planejamento urbano e ideologia. Rio de Janeiro: Civilização Brasileira.

RIBEIRO, L.C.Q.; CARDOSO, A.L. (1990). Plano Diretor e gestão democrática da cidade. GRAZIA, G. (Org.). Plano Diretor: instrumento de reforma urbana. Rio de Janeiro: Fase.

RIBEIRO, L.C.Q.; CARDOSO, A.L. (1994). Planejamento urbano no Brasil: paradigmas e experiências. Espaço e Debates, São Paulo, n. 37, p. 77-89.

RIBEIRO, L.C.Q.; CARDOSO, A.L. (1996). Da cidade à nação: gênese e evolução do urbanismo no Brasil. RIBEIRO, L. C. Q.; PECHMAN, R. (Org.). Cidade, povo e nação-gênese do urbanismo moderno. Rio de Janeiro: Civilização Brasileira.

RIBEIRO, L.C.Q.; SANTOS JR., O.A. (1994). Globalização, fragmentação e reforma urbana: o futuro das cidades brasileiras na crise. Rio de Janeiro: Civilização Brasileira. 
RODWIN, L. (1967). Planejamento urbano nos países em desenvolvimento. Rio de Janeiro: USAID. ROLNIK, R. (1997). A cidade e a lei. São Paulo: Studio Nobel : Fapesp.

ROLNIK, R. (1994). Planejamento urbano nos anos 90: novas perspectivas para velhos temas. RIBEIRO, L.C.Q.; SANTOS JUNIOR, O.A. (Orgs.). Globalização, fragmentação e reforma urbana: o futuro das cidades brasileiras na crise. Rio de Janeiro: Civilização Brasileira.

SANTOS JUNIOR, O.A. (1995). Reforma urbana: por um novo modelo de planejamento e gestão das cidades. Rio de Janeiro: IPPUR/UFRJ-FASE.

SÃO PAULO. (Estado). Secretaria de Economia e Planejamento. (1976). Política de desenvolvimento urbano e regional do Estado de São Paulo. São Paulo, SP.

SÃO PAULO. (Estado). Secretaria de Planejamento. (2006). Região Administrativa de Franca. São Paulo, SP.

SÃO PAULO. (Estado). Secretaria do Interior. (1980). Áreas planejadas para localização industrial. São Paulo, SP. 2 v.

SÃO PAULO. (Estado). Secretaria do Meio Ambiente. (1981). Manual para adequação ambiental na implantação de distritos industriais. São Paulo, SP.

SAULE Jr., N. (1997). Novas perspectivas do direito urbanístico brasileiro. Porto Alegre: Sérgio Fabris Editor.

SERFHAU. Boletim. Rio de Janeiro: n. 34, 1970. 24 p.

SERRA, G. (1989). Urbanização e planejamento autoritário. São Paulo: Studio Nobel.

SERRAN, J.R. ( 1976). O IAB e a política habitacional brasileira. São Paulo: Schema.

SKIDMORE, T. (1979). Brasil: de Getúlio Vargas a Castelo Branco (1930-1964). Rio de Janeiro: Paz e Terra.

SOUZA, M.L. (2003). Mudar a cidade: uma introdução crítica ao planejamento e à gestão urbanos. Rio de Janeiro: Bertrand Brasil.

SOUZA, M.A.A. (1987). A política de formação profissional para o planejamento urbano e regional no Brasil. In: ENCONTRO ANUAL DA ANPOCS, 9., 1987, Águas de São Pedro. Anais... Águas de São Pedro: ANPOCS.

SOUZA, M.A.A. (1988a). Governo urbano. São Paulo: Studio Nobel.

SOUZA, M.A.A. (1988b). Planejamento urbano e modernidade: o conflito processo-método. In: SEMINÁRIO PLANO DIRETOR MUNICIPAL, 1989, São Paulo. Anais... São Paulo: FAUUSP.

SUZIGAN, W. (1986). Indústria brasileira: origem e desenvolvimento. São Paulo: Brasiliense.

TOLEDO, A.H.P.; CAVALCANTI, M. (Org.). (1978). Planejamento urbano em debate. São Paulo: Cortez \& Moraes

TOSI, P.G. (1998). Capitais no interior: Franca e a história da indústria coureiro-calçadista (1860-1945). 1998. 365f. Tese (Doutoramento) - Instituto de Economia, Universidade de Campinas, Campinas.

TRINDADE, M. (1971). Habitação e desenvolvimento Petrópolis: Vozes.

VARGAS, H.C.; CASTILHO, A.L.H. (Org.). (2006). Intervenções em centros urbanos: objetivos, estratégias e resultados. Barueri, SP: Manole.

VEYNE, P.M. (1998). Como se escreve a história: Foucault Revoluciona a História, 4. ed., Brasília, DF:UnB.

VIEIRA, N.M. (1978). Estudo geomorfológico das boçorocas de Franca. Franca: Unesp.

VILLAÇA, F. (1968). A pesquisa do uso da terra urbana e sua aplicação em planos locais integrados. Arquitetura, Rio de Janeiro, n. 71, maio.p.14-21. 
VILLAÇA, F. (1998). Espaço intra-urbano no Brasil. São Paulo: Nobel.

VILLAÇA, F. (1999). Uma contribuição para a história do planejamento urbano no Brasil. DÉAK, C.; SCHIFFER, S. (Org.). O processo de urbanização no Brasil. São Paulo: FUPAM : EDUSP.

VILLAÇA, F. (2005). As ilusões do Plano Diretor. Disponível em: <http:/ / www.fauusp.br/depprojeto/ labhab>. Acesso em: 29 abr. 2006.

VIZIOLI, S.H.T. (1998). Planejamento urbano no Brasil: a experiência do SERFHAU enquanto órgão federal de planejamento integrado ao desenvolvimento nacional. 1998. 138 f. Dissertação (Mestrado) Faculdade de Arquitetura e Urbanismo, Universidade de São Paulo, São Paulo.

WILHEIM, J. (1969). Urbanismo no subdesenvolvimento. Rio de Janeiro: Saga.

XAVIER, A.; LEMOS, C.; CORONA, E. (1983). Arquitetura moderna paulistana. São Paulo: Pini.

YIN, R.K. (2001). Estudo de caso: planejamento e método. Porto Alegre: Bookman.

ZAHN, C.E. (1981). O controle do desenvolvimento urbano. 1980. 360 f. Dissertação (Mestrado) Faculdade de Arquitetura e Urbanismo, Universidade de São Paulo, São Paulo. 



\section{FONTES}

\section{ENTREVISTAS}

ARANTES, A.S.M. (2005). [jan., 2005]. Entrevistador: Mauro Ferreira. Franca.

AUMOND, C.W. (2004). [jul. 2004]. Entrevistador: Mauro Ferreira. São Paulo.

BALIEIRO, A.P. (2005). [jan. 2005]. Entrevistador: Mauro Ferreira. Franca.

CADAVAL, M.C. (2005). [mensagem pessoal]. Mensagem recebida por <mauroferreira52@yahoo.com.br>.em 19 dez.

CORRADI, N. (2004) [jul. 2004]. Entrevistador: Mauro Ferreira. São Paulo.

DAVID, W.D. (2003). [ago. 2003]. Entrevistador: Mauro Ferreira. Franca.

GILBERTI, J.R.C. (2005). [jan. 2005]. Entrevistador: Mauro Ferreira. Franca.

LANCHA FILHO, J. (2005). [jan. 2005]. Entrevistador: Mauro Ferreira. Franca.

MELO, J. S. (2007) [mensagem pessoal]. Mensagem recebida por <mauroferreira52@yahoo.com.br>. em 22 fev.

MELO, M.A. (2007) [mensagem pessoal]. Mensagem recebida por <mauroferreira52@yahoo.com.br>. em 12 mar.

MORANDINI, A.R. (2004). [fev., 2004]. Entrevistador: Mauro Ferreira. Franca.

RAMOS, J.E.O. (2003). [out. 2003]. Entrevistador: Mauro Ferreira. Franca.

RÉSIO, M.A. (2005). [jan. 2005]. Entrevistador: Mauro Ferreira. Franca.

RIBEIRO, F.B. (2005). [fev. 2005]. Entrevistador: Mauro Ferreira. Franca.

RIBEIRO, M.S. (2005). [jan. 2005]. Entrevistador: Mauro Ferreira. Franca.

SOUZA, H.F. (2004). [nov. 2004]. Entrevistadores: Mauro Ferreira e Sarah Feldman. Rio de Janeiro.

SUAVINHO, J.S. (2005). [jan. 2005]. Entrevistador: Mauro Ferreira. Franca.

TEIXEIRA, W.L. (2004). [out. 2004 ]. Entrevistador: Mauro Ferreira. Franca.

ZAHN, C. E. (2004). [ jul. 2004]. Entrevistador: Mauro Ferreira. São Paulo. 


\section{DOCUMENTOS}

FRANCA. Câmara Municipal. (1971). Processo e pareceres das Comissões da Câmara Municipal de Vereadores de Franca ao Projeto de Lei n. 75, de novembro de 1971.

FRANCA. Câmara Municipal. (1972). Processo e pareceres das Comissões da Câmara Municipal de Vereadores de Franca ao Projeto de Lei n. 57, de agosto de 1972.

FRANCA. (1972) Escritura Pública de compra e venda pela Prefeitura Municipal de Franca da área onde se instalaria o Distrito Industrial, de 3 de outubro de 1972 (Dinfra S.A), matriculada sob n. 29.672 no Cartório de Registro de Imóveis e Anexos de Franca

FRANCA. Associação dos Engenheiros e Arquitetos da Região de Franca. (1974). Ata das reuniões realizadas nos dias 24 e27 de setembro de 1974 da Comissão Interna da Associação dos Engenheiros e Arquitetos da Região de Franca sobre o projeto de Lei n. 50/74 em discussão na Câmara Municipal de Franca.

FUNDAÇÃO INSTITUTO BRASILEIRO DE GEOGRAFIA E ESTATÍSTICA. (1970). Censo. Rio de Janeiro: IBGE.

\section{ARTIGOS DE JORNAL}

BOTTO, L. (1987). Contribuição de Melhoria. Quem paga? Comércio da Franca, Franca, 22 set.p.2.

FERREIRA. M. (1975). Revitalização urbana, uma necessidade. Diário da Franca, Franca, 20 nov. p.2.

FERREIRA. M. (1975). Carta aberta à administração municipal. Diário da Franca, Franca, 26 nov. p.4.

FERREIRA. M. (1975). A assessoria ociosa. Diário da Franca, Franca, 24 dez. p. 8.

FERREIRA. M. (1976). Por uns miseráveis votos, a Câmara quer aniquilar o Plano Diretor. Diário da Franca, Franca, 13 mar. p.2.

FERREIRA. M. (1976). O poder público não se interessa pelas áreas verdes. Diário da Franca, Franca, 27 maio. p.8.

FERREIRA. M. (1976). Ainda é tempo de aproveitarem-se as áreas verdes de Franca. Diário da Franca, Franca, 19 jun. p.8.

FERREIRA. M. (1976). Arquiteto condena "espaços vazios"de nosso solo urbano. Diário da Franca, Franca, 1 ago. p. 2.

FERREIRA. M. (1976). O distrito industrial: uma utopia necessária. Diário da Franca, Franca, 20 nov. p.2.

FERREIRA. M. (1977). Conselho vai opinar sobre o Plano Diretor da cidade. Diário da Franca, Franca, 4 jun. p.8.

FERREIRA. M. (1977). O que restringe as edificações em Franca. Diário da Franca, Franca, 14 jul. p. 2.

FERREIRA. M. (1977). Plano Diretor: projeto do vereador instituirá a promiscuidade urbana. Diário da Franca, Franca, 25 nov. p.3.

FERREIRA. M. (1978). Conselho da cidade pode disciplinar o crescimento. Diário da Franca, Franca, 31 mar. p.3.

FERREIRA. M. (1978). Sinal de maturidade. Diário da Franca, Franca, 21 abr. p. 2.

FERREIRA. M. (1978). As alternativas ao desenvolvimento urbano. Diário da Franca, Franca, 24 maio. p.2. 
FERREIRA. M. (1978). Querem trocar a lei do Plano Diretor por votos. Diário da Franca, Franca, 15 jun. p.2.

FERREIRA. M. (1978). Distrito Industrial: subsídios para o debate. Diário da Franca, Franca, 8 out. p.3. FERREIRA. M. (1979). Um projeção da Franca da próxima década. Diário da Franca, Franca, 30 dez. p.8.

FERREIRA. M. (1983). Lazer para os trabalhadores em Franca. Diário da Franca, Franca, 09 jun. p. 8. FERREIRA. M. (1987). Calçadão, quem vai pagar a conta ? Comércio da Franca, Franca, 20 set. p.2. VASQUES, C. (1973). Razões para implantar o Distrito Industrial. Diário da Franca, Franca, 24 dez. p.6. VASQUES, C. (1974). 7 Fortes razões que obrigam a instalar o Distrito Industrial. Diário da Franca, Franca, 24 dez. p.5. 

ANEXOS 


\section{ANEXO 1 \\ Legislação}

\section{Legislação Municipal}

LEI N. 116, 16/11/1950 - Autoriza a elaboração do Plano Diretor da cidade.

LEI N. 345, 18/11/1953 - Dispõe sobre exigências para futuros loteamentos e abertura de novas vilas nesta cidade.

LEI N. 652, 03/07/1957 - Dispõe sobre a criação do Departamento de Engenharia Municipal.

LEI N. 687, 12/02/1958 - Organiza os serviços públicos municipais.

LEI N. 884, 25/04/1960 - Dispõe sobre o levantamento Cadastral da Cidade e indica os recursos adequados.

LEI N. 1095, 21/12/1962 - Regulamento o processo de aprovação de planos de arruamento e loteamento e cria outras condições.

LEI N. 1188, de 09/12/1963 - Dispõe sobre pesquisa e planejamento no Município.

LEI N. 1193, 09/12/1963 - Altera dispositivos do Ato n. 44 de 1 de novembro de 1934.

LEI N. 1204, 22/12/1963 - Estabelece a estrutura e define as atribuições dos órgãos administrativos da Prefeitura Municipal de Franca e dá outras providências.

LEI N. 1217, 27/04/1964 - Concede isenção de emolumentos de plantas de prédios destinados a indústrias.

LEI N. 1285, 23/12/1964 - Regulamenta o processo de aprovação de planos de arruamento e loteamento.

LEI N. 1520,29/06/1967 - Modifica e revoga dispositivos da Lei 1.285, que regulamenta a aprovação de loteamentos.

LEI N. 1521, 14/08/1967 - Autoriza a contratação de serviços e de empréstimo nas condições que especifica. (SERFHAU)

LEI N. 1647, 02/09/1968 - Institui o Código de Edificações do Município de Franca.

LEI N. 1559, 20/11/1967 - Institui o Sistema de Planejamento do Desenvolvimento Integrado do Município de Franca e dá outras providências.

LEI N. 1560, 01/12/1967 - Estabelece a organização do Sistema Administrativo Municipal de Franca e dá outras providências.

LEI N. 1596, 11/03/1968 - Dispõe sobre o Quadro de Pessoal da Prefeitura, estabelece o Plano de Pagamento e dá outras providências. 
LEI N. 1618, 20/05/1968 - Autoriza a doação de terreno para instalação de indústria e dá outras providências.

LEI N. 1639, 12/08/1968 - Autoriza o Executivo a dar imóvel em garantia de financiamento. (SERFHAU)

LEI N. 1672, 07/10/1968 - Institui o Código Tributário do Município de Franca.

LEI N. 1688, 09/12/1968 - Dispõe sobre a desapropriação de área de terreno pertencente ao sr. José Cirino Goulart. (Vale dos Bagres)

LEI N. 1699, de 12/12/1968 - Dispõe sobre a criação de cargos e modifica enquadramento de pessoal ativo e inativo do funcionalismo público municipal.

LEI N. 1747, 02/06/1969 - Estabelece nova redação para o artigo 9 da Lei 1.520, que regulamenta a aprovação de loteamentos.

LEI N. 1749, 30/06/1969 - Delimita o perímetro urbano da cidade de Franca.

LEI N. 1830, 15/12/1969 - Fixa em 12 anos o prazo de isenção para as indústrias pioneiras.

LEI N. 1859, 20/04/1970 - Proíbe a aprovação de planos de loteamentos e arruamento no Município de Franca.

LEI N. 1861, 0/05/1970 - Adapta a Estrutura Administrativa da Prefeitura Municipal às exigências da Lei Orgânica do Município.

LEI N. 1955, 15/12/1970 - Autoriza o Executivo a expropriar, por via amigável, imóveis que especifica. (Vale dos Bagres)

LEI N. 2046, 06/01/1972 - Institui o Plano Diretor Físico do Município de Franca, suas normas ordenadoras e disciplinadoras e dá outras providências.

LEI N. 2047, de 07/01/1972 - Institui o Código de Posturas do Município e dá outras providências.

LEI N. 2100, 21/09/1972 - Autoriza o Executivo a expropriar, por via amigável, área de terra para a instalação do Distrito Industrial e dá outras providências.

LEI N. 2265, 29/11/1974 - Dispõe sobre alteração na Lei 2.046, Plano Diretor físico do Município.

LEI N. 2320, 24/09/1975 - Cria uma empresa pública sob a denominação de EMDEF - EMPRESA MUNICIPAL PARA O DESENVOLVIMENTO DE FRANCA e institui o PLANO COMUNITÁRIO MUNICIPAL.

LEI N. 2373,de 19/12/1975 - Dispõe sobre edificações na Praça Barão da Franca e na Praça Nossa Senhora da Conceição.

LEI N. 2448, de 23/12/1976 - Delimita o perímetro urbano da cidade de Franca.

LEI N. 2497, de 27/12/1977 - Dispõe sobre alterações de dispositivos da Lei n. 2046, de 06 de janeiro de 1972 e dá outras providências.

LEI N. 2513, de 16/06/1978 - Dispõe sobre alterações do Plano Diretor Físico do Município de Franca.

LEI N. 2552, de 16/11/1978 - Cria o PLANO DE DESENVOLVIMENTO INDUSTRIAL DE FRANCA PLADEIN, estabelecendo diretrizes e normas para o seu funcionamento.

LEI N. 2628, de 07/01/1980 - Altera dispositivo do Plano de Desenvolvimento Integrado do Município de Franca.

LEI N. 2759, 05/11/1981 - Dispõe sobre alteração na Lei 2.046, Plano Diretor físico do Município.

LEI N. 2815, 30/08/1982 - Dispõe sobre alteração na Lei 2.046, Plano Diretor físico do Município.

LEI N. 2852, de 13/04/1983 - Modifica dispositivos da lei 2046, de 06 de janeiro de 1972, estabelece requisitos complementares à aprovação de projetos de parcelamento do solo e dá outras providências.

LEI N. 2863, 24/06/1983 - Autoriza a constituição do DINFRA - Distritos Industriais de Franca e dá outras providências.

LEI N. 2931, 29/06/1984 - Concede isenção de IPTU às empresas que se instalarem no Distrito Industrial. 
ANEXO 2

Fotos Aéreas 



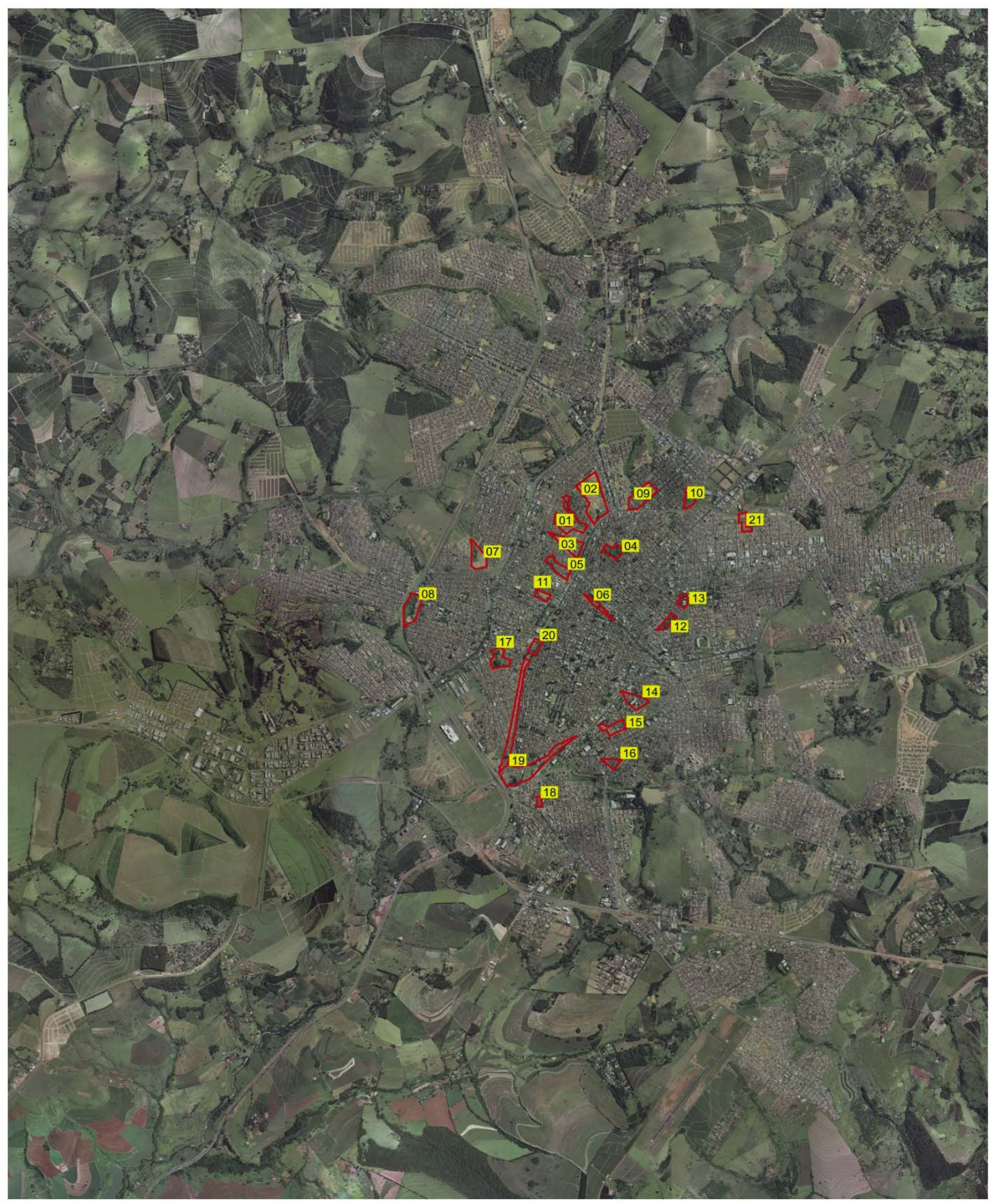

\section{LEGENDA:}

01 Voçoroca do Parque São Jorge 02 Voçoroca das Maritacas 03 Voçoroca da Vila Catocos 04 Voçoroca da Vila Monteiro 05 Voçoroca da Boa Vista 06 Voçoroca do Pestalozzi 07 Voçoroca do Jardim Conceição Leite 08 Voçoroca da Vila Raycos 09 Voçoroca da Ponte Preta 10 Voçoroca da Vila Planalto
11 Voçoroca da Vila Samelo 12 Voçoroca da Vila Palmeiras 13 Voçoroca da Manuel Valim 14 Voçoroca da Scarabucci 15 Voçoroca do Quirino 16 Voçoroca do Chiné 17 Voçoroca da Higienópolis 18 Voçoroca da Adalgiso Leite 19 Fundo de Vale do Córrego dos Bagres 20 Parque Vale dos Bagres 21 Voçoroca da Vila Isabel
MAPA 1

ÁREAS VERDES PARA FINS PAISAGÍSTICOS 


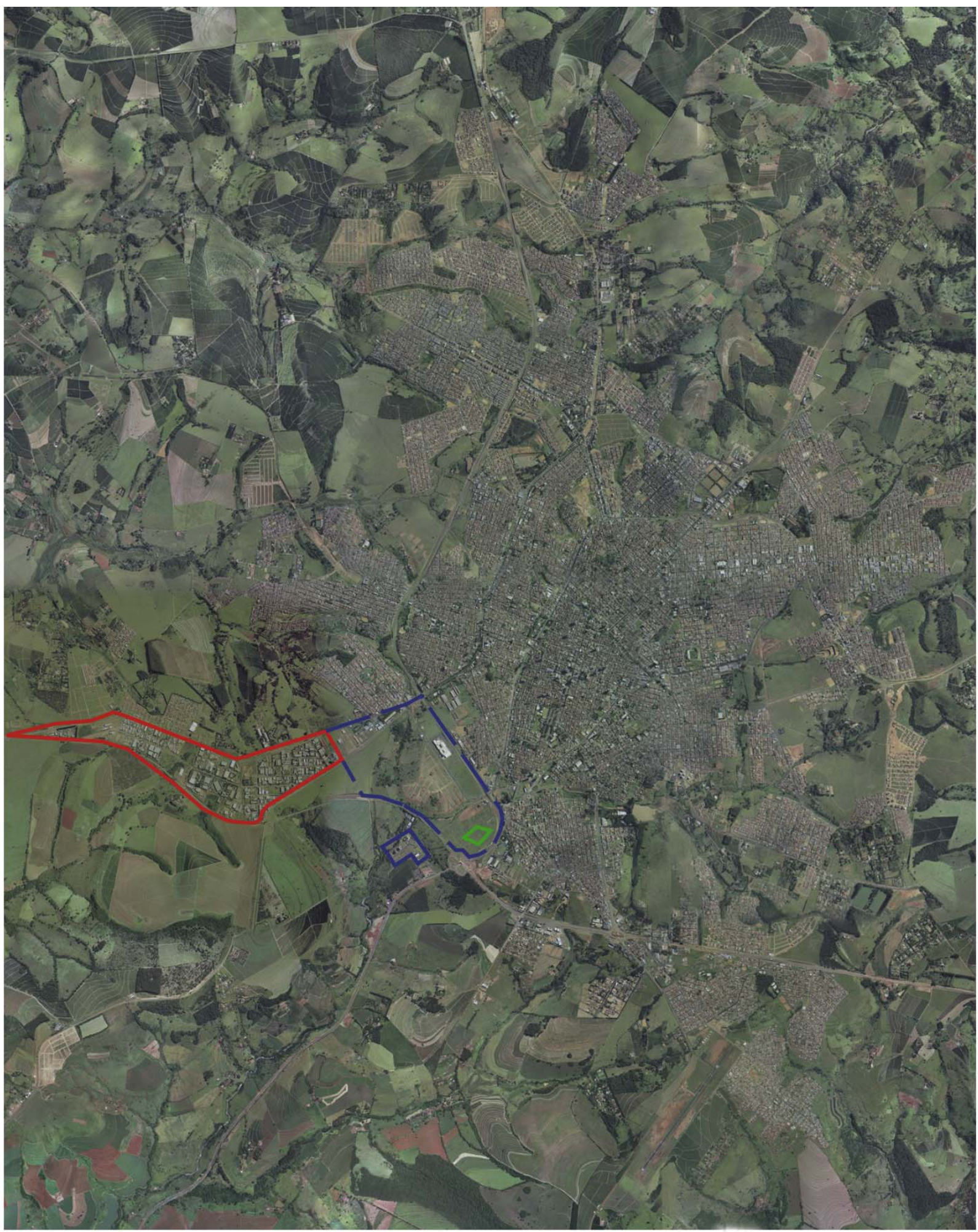

LEGENDA:

Distrito Industrial

- - Área original prevista para implantar o Distrito Industrial

- ETE

_ Área original prevista para implantar a ETE
MAPA 2

DISTRITO INDUSTRIAL 


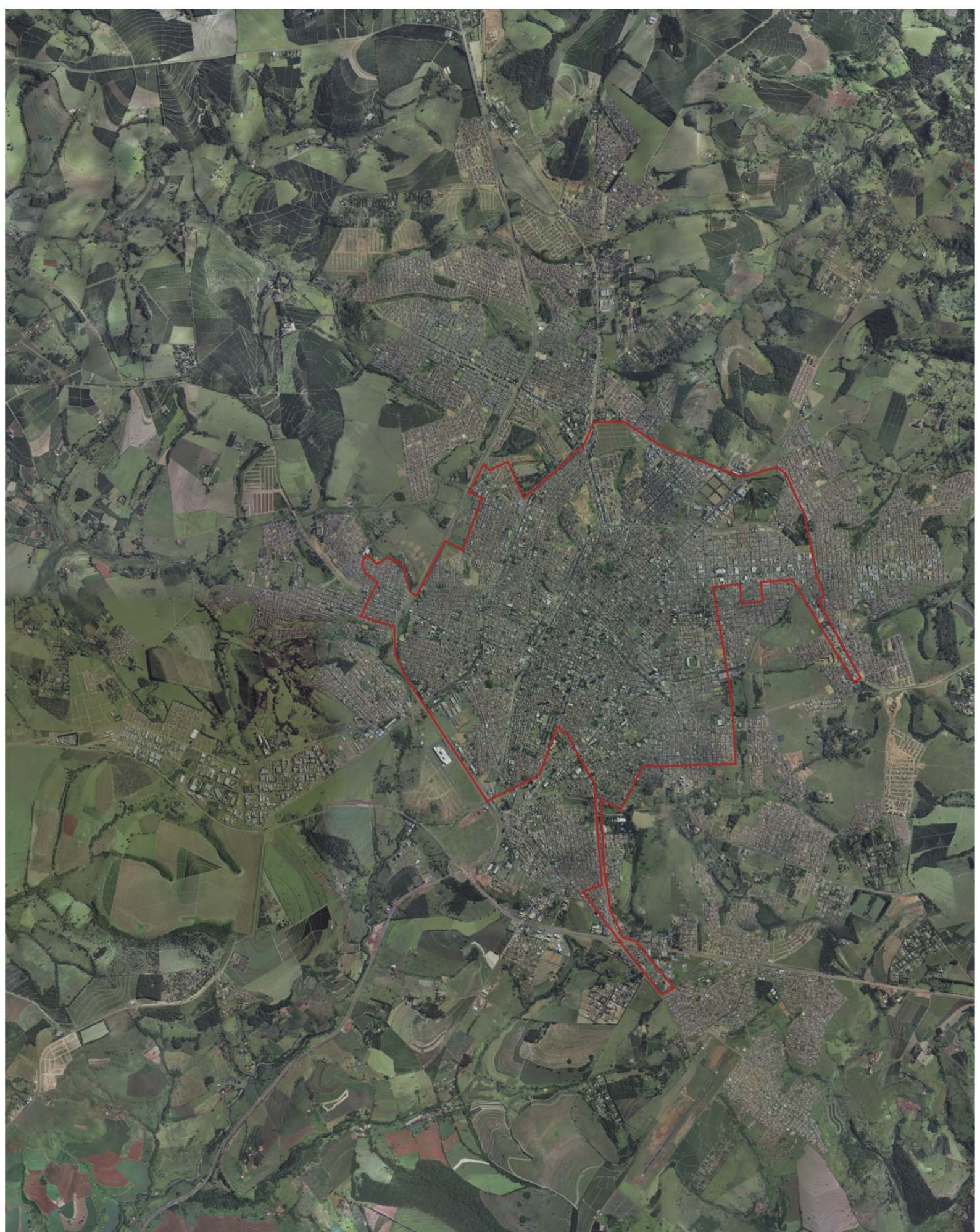

LEGENDA:

MAPA 3 PERÍMETRO URBANO 


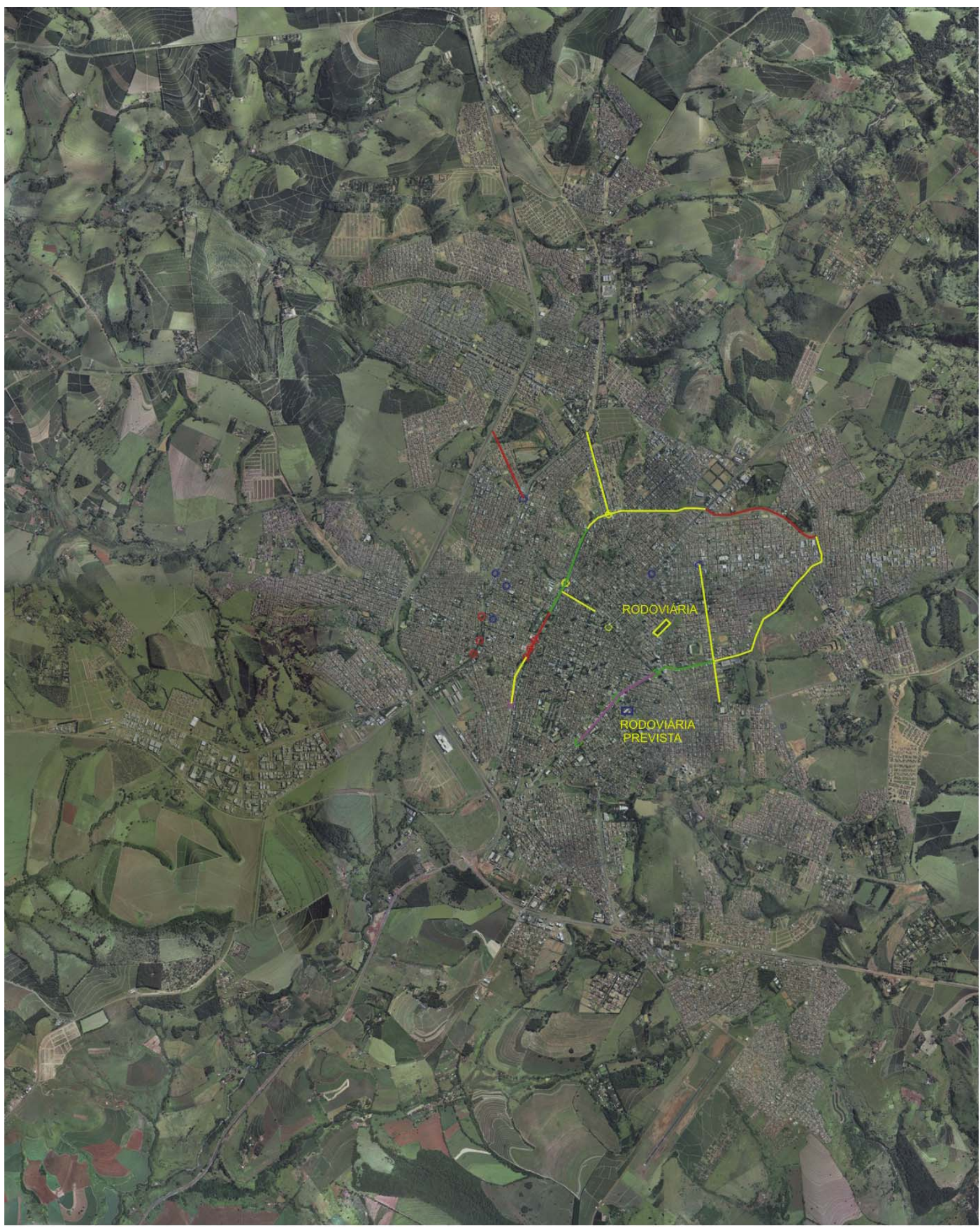

LEGENDA:

— Intervenções realizadas na década de 90 Intervenções realizadas na década de 80 Intervenções realizadas na década de 70 Intervenções realizadas na década de 60 Intervenções previstas mas não realizadas
MAPA 4 SISTEMA VIÁRIO 


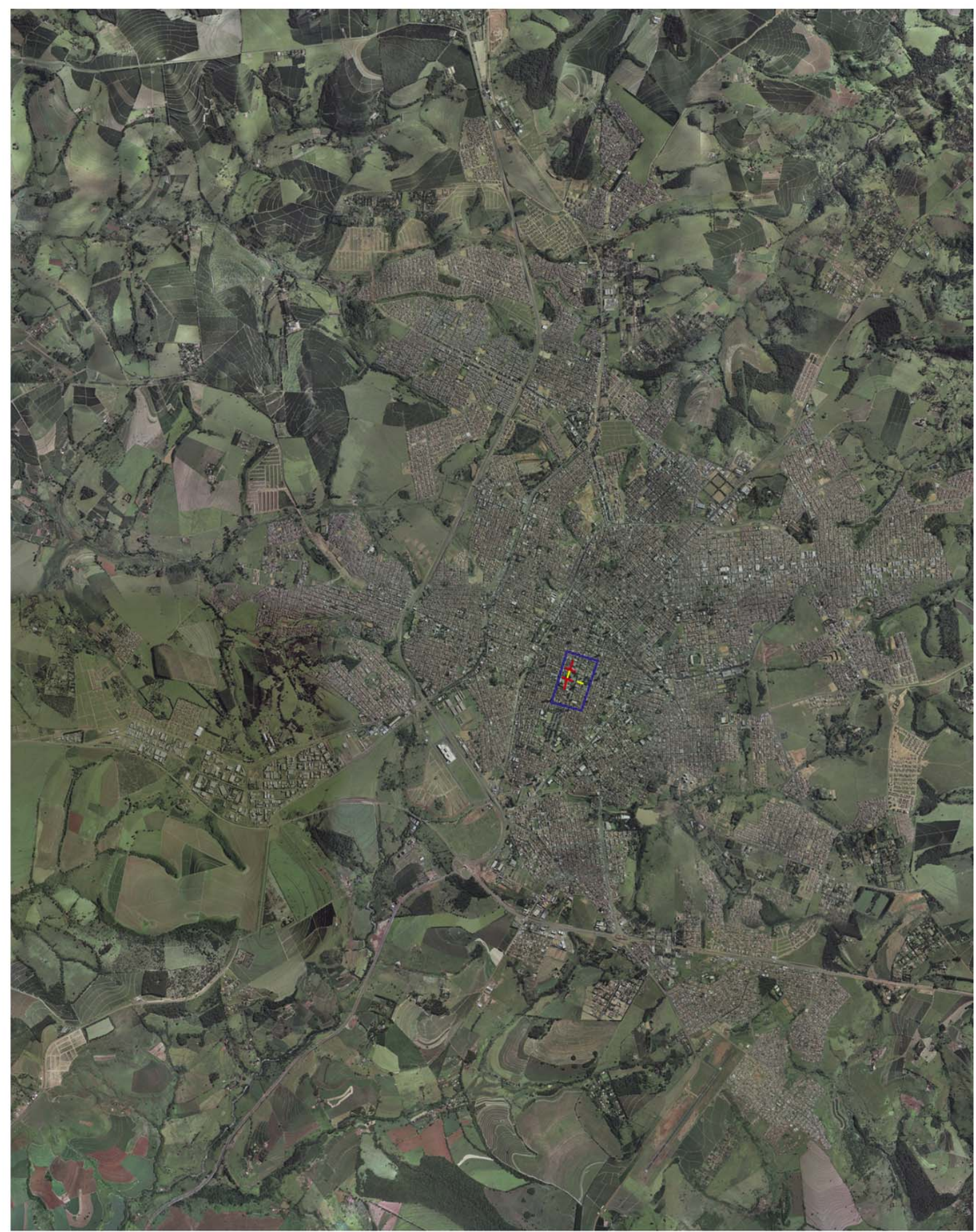

LEGENDA:

Intervenções realizadas na década de 90

Intervenções realizadas na década de 80

— Intervenções não realizadas
MAPA 5

ZONA COMERCIAL E ANEL GIRATÓRIO 


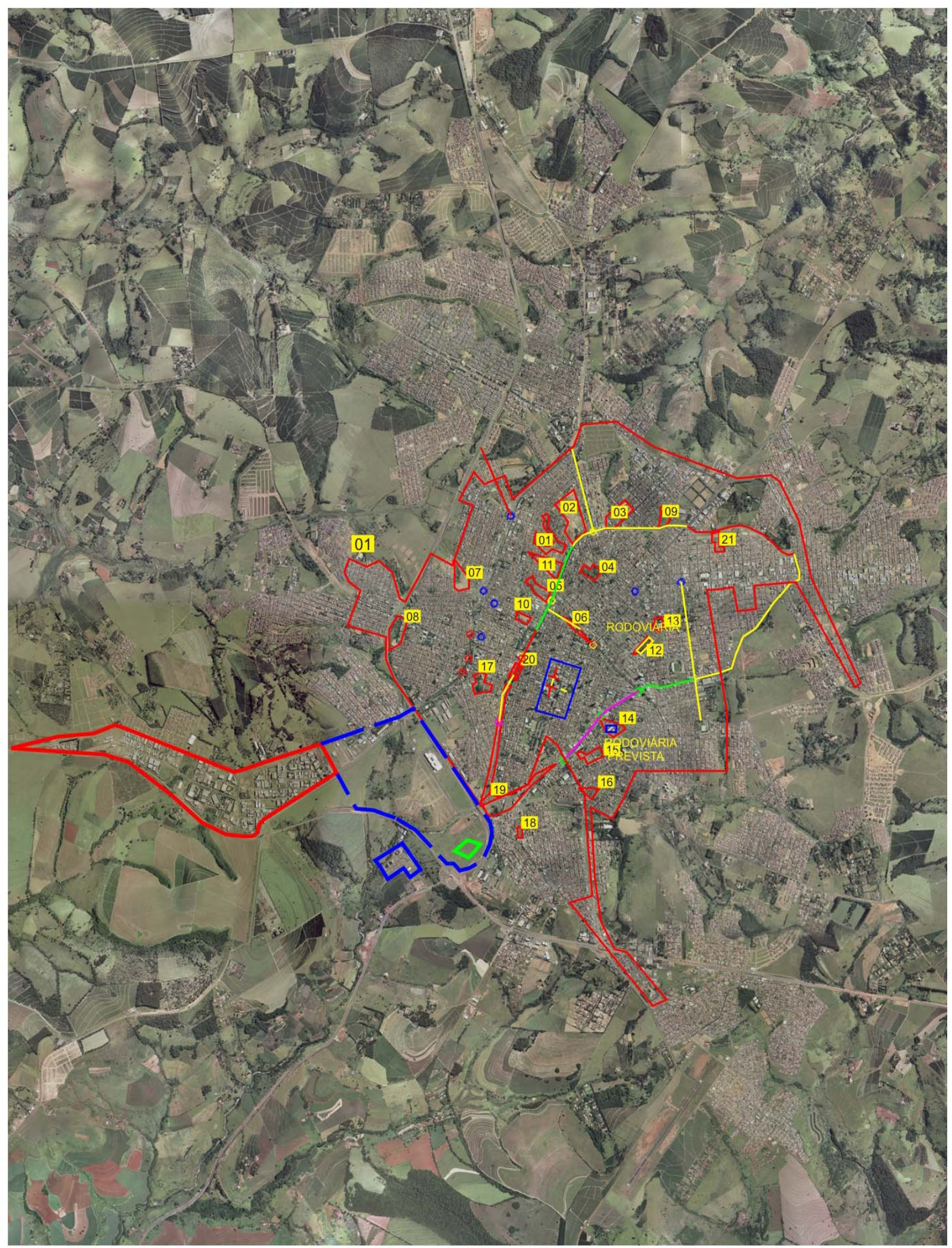


